Lísias Pereira Novo

\title{
Determinação da relação dos parâmetros de solubilidade de Hansen de solventes orgânicos com a deslignificação organossolve de bagaço de cana-de-açúcar
}

Dissertação apresentada ao Instituto de Química de São Carlos da Universidade de São Paulo como parte dos requisitos para a obtenção do título de mestre em química

Área de concentração: Físico-química

Orientador: Prof. Dr. Antonio Aprigio da Silva Curvelo

São Carlos

2012 


\section{Exemplar revisado}

O exemplar original encontra-se disponível no Serviço de Pós-Graduação do IQSC-USP.

Ficha Catalográfica elaborada pela Seção de Referência e Atendimento ao Usuário do SBI/IQSC

Novo, Lísias Pereira

Determinação da relação dos parâmetros de solubilidade de Hansen de solventes orgânicos com a deslignificação organossolve de bagaço de cana-deaçúcar. / Lísias Pereira Novo. -- São Carlos, IQSC, 2012. $139 \mathrm{p}$.

Dissertação (Mestrado) - Instituto de Química de São Carlos / Universidade de São Paulo, 2012.

Edição revisada

Orientador: Prof. Dr. Antonio Aprigio da Silva Curvelo

1. Deslignificação organossolve. I.Título.

Referencias Bibliográficas conferidas pelo SBIIIQSC 
Dedico este trabalho minha Mãe e Pai, Furídice e Djalma, à minha familia e à minha noiva Brunella Orlandi. 



\section{AGRADECIMENTOS}

Agradeço primeiramente ao Prof. Dr. Antonio Aprigio da Silva Curvelo que me permitiu a realização do trabalho em seu grupo de pesquisa e pelo seu auxílio constante nas questões e nas discussões ligadas à ciência, futebol e diversos outros temas.

Agradeço em segundo a minha família biológica que sem o apoio dos quais nada disso poderia ser feito. Em especial a minha mãe e pai que me aturam diariamente, mesmo nos momentos de estresse e nervosismo. Agradeço também à minha noiva Brunella que com seu amor e amizade facilitam a minha passagem pelos diversos contratempos. Aos meus irmãos Ana Elisa, Crysthiano, Marina, Júnior, Marcio, Marileide, Raphael e Paulo que sempre ofereceram suas amizades e convivência. À Marli e Rui, futuros sogros, pelos diversos churrascos oferecidos sem os quais não haveria possibilidade de relaxar.

Agradeço agora, à minha família do coração pelo carinho e amizade proporcionado, em especial ao Herbert (perereca) pelas discussões sobre todos os mais diversos temas imaginados, incluindo a química, pela amizade em praticamente toda a minha vida profissional, desde o início no PET até os dias atuais no mestrado. Agradeço aos amigos da "panelinha" (e também dos "refratários"), em especial ao Marcos (soneca), Eder (prodígo), Thiago, Daiane, Vivian, Gabriela, Rubens (taquara), Silvio (Juba) e Marcio (Mion) que sempre estiveram (e sempre estarão) presentes mesmo com o distanciamento devido a formatura ou pela formação de suas novas famílias nucleares.

Agradeço, aos meus colegas e amigos de laboratório, com os quais cresci profissionalmente com as discussões sobre físico-química orgânica e sobre a biomassa vegetal em geral, Leandro, Maria, Karen, Bárbara, Luisão, Luiz Ramos e Márcia Zambom.

Aos meus amigos mais antigos, Gabriel (P) e Fernando (N) que apesar da distância e dificuldades de contato ainda moram no meu coração.

Ao CNPq pela bolsa concedida. E a FAPESP/Oxiteno pelo fomento ao grupo.

Agradeço, em fim, à Deus e a espiritualidade amiga pela oportunidade de reencarnação e evolução, pelo trabalho e pelas dificuldades encontradas. 



\section{RESUMO}

O uso do bagaço de cana-de-açúcar, um subproduto da produção sucroalcooleira, ainda está hoje atrelado diretamente à produção de energia com sua queima nas usinas, um uso que é pouco nobre, considerando-se a grande diversidade de compostos químicos presentes neste tipo de material. A possibilidade de valorização desta matéria-prima lignocelulósica está ligada a realização de etapas de separação das principais frações de compostos, a celulose, as hemiceluloses e a lignina. Neste contexto, as deslignificações organossolve, etapa de remoção da lignina através da solubilização da mesma em soluções orgânicas, tem grande potencial de uso, visto que nestas pode-se recuperar tanto a polpa como o licor de polpação para posterior uso. Assim, verifica-se que a solubilidade da lignina é o fator que diferencia a utilização de um dado solvente orgânico em uma deslignificação organossolve. Desta maneira, pode-se utilizar o conceito de parâmetros de solubilidade para a escolha de um melhor solvente para o processo. Neste trabalho, verificou-se a relação entre a deslignificação organossolve e a distância e afinidade de um solvente com a esfera de solubilidade de Hansen para a lignina de bagaço de cana-de-açúcar. Verificou-se que os parâmetros de solubilidade de Hansen para a lignina verificados na literatura não apresentam boa correlação com os dados de deslignificação, porém, uma nova esfera de solubilidade foi desenvolvida, na qual verificou-se um coeficiente de determinação de 0,93856, em detrimento de um de 0,72074 para a esfera de solubilidade verificada na literatura. Concluiu-se que o modelo desenvolvido possuía como principal diferença com relação ao modelo obtido por Hansen e Björkman para a lignina, um parâmetro de solubilidade para interações intermoleculares polares $\left(\delta_{p}\right)$ inferior e um parâmetro de solubilidade para a capacidade de realização de ligações de hidrogênio $\left(\delta_{h}\right)$ bem superior, porém mantendo o mesmo parâmetro de solubilidade total $(\delta)$. Confirmouse a relação entre a deslignificação e os valores de distância e de afinidade obtidos neste trabalho, com a realização de deslignificações usando misturas ternárias e quaternárias com solventes de baixo custo e/ou excedentes no mercado (etanol, glicerol e 2-butanol, além de água). Concluiu-se que apesar da esfera de solubilidade desenvolvida permitir melhor ajuste dos dados, não se pode afirmar que esta é com certeza a esfera real para a lignina.

Palavras-chave: Bagaço de cana-de-açúcar; deslignificação organossolve; parâmetros de solubilidade de Hansen. 



\begin{abstract}
The use of sugarcane bagasse, a by-product of sugar and ethanol production, is still linked today directly to energy production with its burning in power plants, a use which is not very noble, considering the great diversity of chemical compounds present in the lignocellulosic matrix. The possibility of better use of lignocellulosic feedstock is linked to steps of separation of their main fractions, cellulose, hemicelluloses and lignin. In this context, organosolv delignification, in which lignin is removed by the solubilization in organic solutions have great potential, since both pulps and the pulping liquor can be recovered for later use. Thus, since the solubility of lignin is the factor that differentiates the use of a given organic solvent in an organosolv delignification, the concept of solubility parameters can be used for the selection of the organic solvent. In this dissertation the relationship between the distance and the affinity of a solvent with the Hansen sphere of solubility for lignin from bagasse cane sugar and organosolv delignification were studied. It was found that the Hansen solubility parameters for lignin found in the literature do not present a good correlation with delignification data. Thus a new sphere of solubility was developed, with a determination coefficient of 0.93856 , over a determination coefficient of 0.72074 for the sphere of solubility found in the literature. It was concluded that the main differences between the developed model and the model obtained by Hansen and Björkman for lignin were a lower solubility parameter for polar intermolecular interactions $\left(\delta_{p}\right)$ and a higher solubility parameter for hydrogen bonds $\left(\delta_{h}\right)$, however keeping the same total solubility parameter $(\delta)$. The relationship between delignification and the values of the distance and affinity obtained in this work were confirmed with the attainment of organosolv delignification using tertiary and quaternary mixtures of solvents with low cost and/or availability in the market (ethanol, glycerol and 2-butanol, in addition to water). It was concluded that although the developed solubility sphere allowed a better fit of the data, it cannot be stated with certainty that this is the real sphere for lignin.
\end{abstract}

Keywords: Sugarcane bagasse; organosolv delignification; Hansen solubility parameters. 



\section{LISTA DE FIGURAS}

Figura 01 - Corte transversal do talo de uma cana-de-açúcar.

Figura 02 - Características visuais das frações do bagaço de cana-de-açúcar. a) Fração fibra;

b) Fração medula.

Figura 03 - Representação de uma molécula de celulose.

Figura 04 - Representação das ligações de hidrogênio intra e intermolecular da celulose. 24

Figura 05 - Estruturas de ressonância da terminação redutora da estrutura da celulose. 25

Figura 06 - Representação das moléculas dos açúcares precursores das polioses. 27

Figura 07 - Modelos de associação dos componentes celulares macromoleculares. a) Preston (1962); b) Marchessault (1964); c) Kerr e Göring (1975); d) Fengel (1970); e) Salmén and Olsson (1998). 28

Figura 08 - Unidade básica fenil-propânica e álcoois precursores da lignina. 30

Figura 09 - Exemplos de unidades menos usuais de precursores da lignina. 30

Figura 10 - Estrutura sugerida para lignina de madeiras moles. 31

Figura 11 - Possíveis grupos funcionais presentes em uma lignina. 33

Figura 12 - Estruturas de ressonância do íon fenolato.

Figura 13 - Mecanismo de formação do intermediário do tipo metileno quinona e posteriores reações em meio alcalino. 41

Figura 14 - Mecanismo simplificado de quebra da ligação $\beta-0-4$ em polpações Kraft. 42

Figura 15 - Reação de óxido-redução da antraquinona na presença de carboidratos. 43

Figura 16 - Mecanismo de quebra da ligação $\beta-0-4$ em polpações com antraquinona. 43

Figura 17 - Fragmentação da lignina sugerida durante o processo MWL. 44

Figura 18 - Mecanismo de formação de 3 carbocátions na cadeia lateral. 45

Figura 19 - Sítios de alta $\left(\delta^{-}\right)$e baixa $\left(\delta^{+}\right)$densidade eletrônica em meio ácido de unidades arilpropano (a) e arilpropeno (b). 46

Figura 20 - Mecanismo de solvólise da ligação a-O-4. 46

Figura 21 - Um dos possíveis mecanismos de solvólise da ligação $\beta-0-4$. 47

Figura 22 - Reações de condensação de ligninas em meio ácido. 48

Figura 23 - Representação do parâmetro de solubilidade de HANSEN para a lignina de madeira. .. 55

Figura 24 - Deslignificações organossolve de diversos solventes versus parâmetro de solubilidade de Hildebrand. 60

Figura 25 - Fluxograma de etapas padrão. 
Figura 26 - Variação dos parâmetros de solubilidade versus razão volumétrica entre os solventes orgânicos.

Figura 27 - Variação de $R a$ versus razão volumétrica entre os solventes orgânicos.......................... 75

Figura 28 - Variação de RED versus razão volumétrica entre os solventes orgânicos. ...................... 76

Figura 29 - Dados de deslignificação versus parâmetros de solubilidade de Hildebrand. .82

Figura 30 - Gráfico de Ra para os diferentes solventes utilizados versus deslignificação: a) 2-butanol imiscível em água; e b) 2-butanol miscível em água.

Figura 31 - Gráfico de RED para os diferentes solventes versus deslignificação: a) 2-butanol imiscível em água; e b) 2-butanol miscível em água.

Figura 32 - Modelo do programa para gerar parâmetros de solubilidade para polímeros. .89

Figura 33 - Gráfico de $R a$ para os parâmetros de solubilidade da corrida 1 versus deslignificação para: a) 2-butanol imiscível em água; e b) 2-butanol miscível em água.

Figura 34 - Gráfico de RED para os parâmetros de solubilidade da corrida 1 versus deslignificação para: a) 2-butanol imiscível em água; e b) 2-butanol miscível em água.

Figura 35 - Gráfico de Ra para os parâmetros de solubilidade da corrida 2 versus deslignificação para: a) 2-butanol imiscível em água; e b) 2-butanol miscível em água.

Figura 36 - Gráfico de RED para os parâmetros de solubilidade da corrida 2 versus deslignificação para: a) 2-butanol imiscível em água; e b) 2-butanol miscível em água.

Figura 37 - Gráfico de Ra para os parâmetros de solubilidade da corrida 3 versus deslignificação para: a) 2-butanol imiscível em água; e b) 2-butanol miscível em água.

Figura 38 - Gráfico de RED para os parâmetros de solubilidade da corrida 3 versus deslignificação para: a) 2-butanol imiscível em água; e b) 2-butanol miscível em água.

Figura 39 - Gráfico de Ra para os parâmetros de solubilidade da corrida 4 versus deslignificação para: a) 2-butanol imiscível em água; e b) 2-butanol miscível em água.

Figura 40 - Gráfico de RED para os parâmetros de solubilidade da corrida 4 versus deslignificação para: a) 2-butanol imiscível em água; e b) 2-butanol miscível em água.

Figura 41 - Gráfico de Ra para os parâmetros de solubilidade da corrida 5 versus deslignificação para: a) 2-butanol imiscível em água; e b) 2-butanol miscível em água.

Figura 42 - Gráfico de RED para os parâmetros de solubilidade da corrida 5 versus deslignificação para: a) 2-butanol imiscível em água; e b) 2-butanol miscível em água. 100

Figura 43 - Curva de distribuição normal de dados, o número de desvios padrão em relação à média e a densidade de probabilidade. 
Figura 44 - Gráfico de $R a$ para as misturas terciárias e a mistura quaternária em relação aos parâmetros de solubilidade da literatura versus deslignificação para: a) 2-butanol imiscível em água; e b) 2-butanol miscível em água..

Figura 45 - Gráfico de $R E D$ para as misturas terciárias e a mistura quaternária em relação aos parâmetros de solubilidade da literatura versus deslignificação para: a) 2-butanol imiscível em água; e b) 2-butanol miscível em água...

Figura 46 - Gráfico de $R a$ para as misturas terciárias e a mistura quaternária em relação aos parâmetros de solubilidade da corrida 1 versus deslignificação para: a) 2-butanol imiscível em água; e b) 2-butanol miscível em água 108

Figura 47 - Gráfico de RED para as misturas terciárias e a mistura quaternária em relação aos parâmetros de solubilidade da corrida 1 versus deslignificação para: a) 2-butanol imiscível em água; e b) 2-butanol miscível em água..

Figura 48 - Gráfico de Ra para as misturas terciárias e a mistura quaternária em relação aos parâmetros de solubilidade da corrida 2 versus deslignificação para: a) 2-butanol imiscível em água; e b) 2-butanol miscível em água......

Figura 49 - Gráfico de RED para as misturas terciárias e a mistura quaternária em relação aos parâmetros de solubilidade da corrida 2 versus deslignificação para: a) 2-butanol imiscível em água; e b) 2-butanol miscível em água...

Figura 50 - Gráfico de $R a$ para as misturas terciárias e a mistura quaternária em relação aos parâmetros de solubilidade da corrida 3 versus deslignificação para: a) 2-butanol imiscível em água; e b) 2-butanol miscível em água..

Figura 51 - Gráfico de $R E D$ para as misturas terciárias e a mistura quaternária em relação aos parâmetros de solubilidade da corrida 3 versus deslignificação para: a) 2-butanol imiscível em água; e b) 2-butanol miscível em água...

Figura 52 - Gráfico de Ra para as misturas terciárias e a mistura quaternária em relação aos parâmetros de solubilidade da corrida 4 versus deslignificação para: a) 2-butanol imiscível em água; e b) 2-butanol miscível em água..

Figura 53 - Gráfico de $R E D$ para as misturas terciárias e a mistura quaternária em relação aos parâmetros de solubilidade da corrida 4 versus deslignificação para: a) 2-butanol imiscível em água; e b) 2-butanol miscível em água......

Figura 54 - Gráfico de $R a$ para as misturas terciárias e a mistura quaternária em relação aos parâmetros de solubilidade da corrida 5 versus deslignificação para: a) 2-butanol imiscível em água; e b) 2-butanol miscível em água...

Figura 55 - Gráfico de $R E D$ para as misturas terciárias e a mistura quaternária em relação aos parâmetros de solubilidade da corrida 5 versus deslignificação para: a) 2-butanol imiscível em água; e b) 2-butanol miscível em água.. 
Figura 56 - Comparação entre distancias e afinidades entre a corrida de melhor ajuste e o dado obtido na literatura, para 2-butanol imiscível em água: a) $R a$ Literatura; b) $R E D$ Literatura;

c) $R a$ corrida 1 ; d) $R E D$ corrida 1 118

Figura 57 - Comparação entre distancias e afinidades entre a corrida de melhor ajuste e o dado obtido na literatura, para 2-butanol miscível em água: a) $R a$ Literatura; b) $R E D$ Literatura;

c) $R a$ corrida 2 ; d) RED corrida 2. 119

Figura 58 - Distancias entre os solventes e o centro da melhor esfera de solubilidade da lignina versus deslignificação.

Figura 59 - Afinidade entre os solventes e o centro da melhor esfera de solubilidade da lignina versus deslignificação.

Figura 60 - Distancias entre os solventes e o centro da r esfera de solubilidade da corrida 1 versus deslignificação, com exclusão do 1,4-dioxano.

Figura 61 - Afinidades entre os solventes e o centro da esfera de solubilidade da corrida 1 versus deslignificação, com exclusão do 1,4-dioxano. 122

Figura 62 - Distancias entre os solventes e o centro da melhor esfera de solubilidade da lignina versus deslignificação, com exclusão do 1,4-dioxano

Figura 63 - Afinidades entre os solventes e o centro da melhor esfera de solubilidade da lignina versus deslignificação, com exclusão do 1,4-dioxano. 


\section{LISTA DE TABELAS}

Tabela 01 - Composição de monômeros de lignina em diferentes plantas.

Tabela 02 - Parâmetros de solubilidade de Hansen para os solventes puros e para as soluções utilizadas nas deslignificações.

Tabela 03 - Resultados dos testes para definição das condições reacionais para a deslignificação. 77

Tabela 04 - Temperaturas de ebulição dos solventes utilizados 79

Tabela 05 - Resultados das polpações organossolve para os solventes estudados, com 125ㄷ, 60 minutos de reação, concentração de $\mathrm{HCl}$ de $0,05 \mathrm{~mol}$.L-1, razão solvente principal/água de 9/1 e razão sólido/líquido igual a 1/10.

Tabela 06 - Resultados de deslignificação para serragem de Pinus caribaea hondurensis.

Tabela 07 - Valores de $R a$ e $R E D$ para os solventes utilizados puros e com 10\% de água. 87

Tabela 08 - Dados de solubilidade inseridos no programa para diferentes porcentagens de deslignificação mínima e parâmetros de solubilidade da literatura e gerados para lignina, considerando o 2-butanol como imiscível em água.

Tabela 09 - Dados de solubilidade inseridos no programa para diferentes porcentagens de deslignificação mínima e parâmetros de solubilidade gerados para lignina, considerando o 2-butanol como miscível em água.

Tabela 10 - Distâncias e afinidades com as ligninas das corridas, considerando o 2-butanol como imiscível em água.

Tabela 11 - Distâncias e afinidades com as ligninas das corridas, considerando o 2-butanol como miscível em água.

Tabela 12 - Parâmetros de solubilidade de Hansen para as três soluções ternárias e para a quaternária, e seus resultados.

Tabela 13 - Distâncias e afinidades com a lignina das corridas e da literatura, para as três misturas ternárias e a mistura quaternárias, considerando o 2-butanol como imiscível em água.

Tabela 14 - Distâncias e afinidades com a lignina das corridas, para as três misturas ternárias e a mistura quaternária, considerando o 2-butanol como miscível em água.

Tabela 15 - Comparação entre os dados de solubilidade inseridos no programa e dos parâmetros de solubilidade da corrida 1 , da corrida de otimização e da literatura.

Tabela 16 - Comparação entre as distâncias e afinidades com as ligninas das corridas 1 e 6 e da literatura. 



\section{SUMÁRIO}

1 INTRODUÇÃO

1.1 CANA-DE-ACUUCAR NO BRASIL E O MEIO AMBIENTE ................................19

1.2 CARACTERIZAÇÃO DA CANA-DE-ACUÚCAR E DERIVADOS …....................20

1.2.1 CARACTERIZAÇÃO ESTRUTURAL DA CANA-DE-AÇÚCAR ................................20

1.2.2 CARACTERIZAÇÃO MORFOLÓGICA E QUÍMICA DO BAGAÇO DE CANA-DE-AÇÚCAR.21

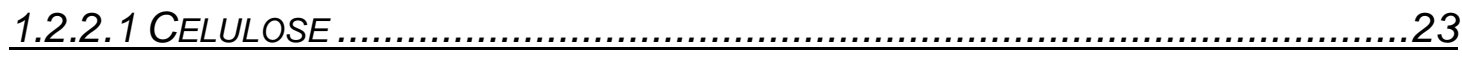

1.2.2.2 HEMICELULOSES .................................................................26

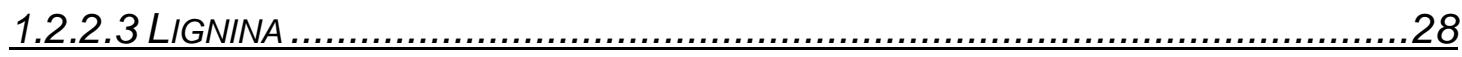

1.2.2.3.1 CARACTERIZAÇÃO DE LIGNINAS NO ESTADO SÓLIDO.....................................33

1.2.2.3.2 CARACTERIZAÇÃO DE LIGNINAS EM SOLUÇÃO ……...................................... 36

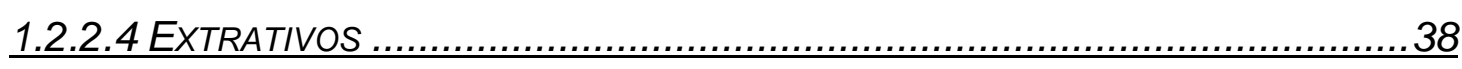

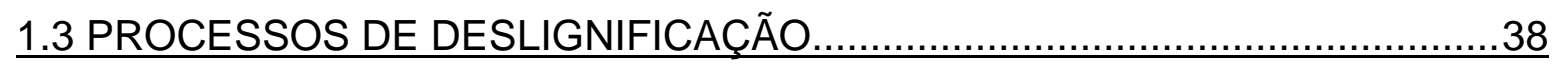

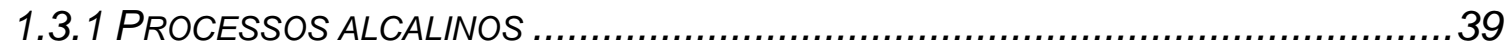

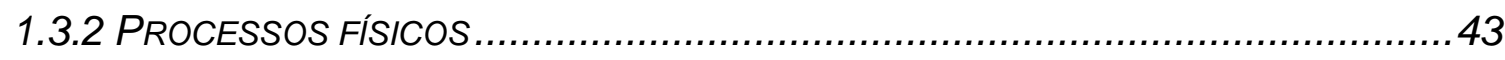

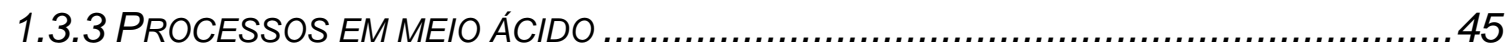

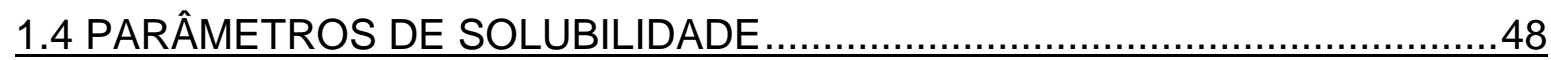

1.4.1 PARÂMETRO DE SOLUBILIDADE DE HILDEBRAND........................................ 49

1.4.2 PARÂMETROS DE SOLUBILIDADE DE HANSEN ..........................................

1.4.2.1 CÁLCULO DOS PARÂMETROS DE SOLUBILIDADE DE HANSEN …...................52

1.4.2.2 PARÂMETROS DE SOLUBILIDADE DE HANSEN PARA POLÍMEROS.................54

1.4.2.3 VARIACÃO DOS PARÂMETROS DE HANSEN COM A TEMPERATURA ................56

1.4.2.4 EFEITO DO VOLUME MOLAR E GEOMETRIA DO SOLVENTE NA SOLUBILIDADE. 57

1.5 APLICAÇÕES DE PARÂMETROS DE SOLUBILIDADE …….......................58

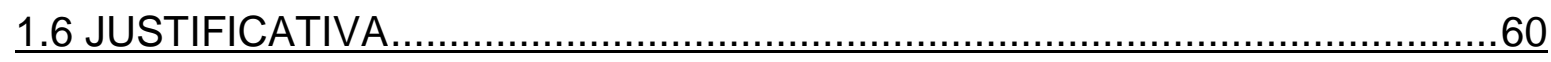

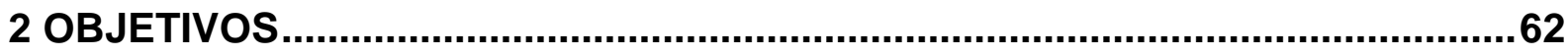

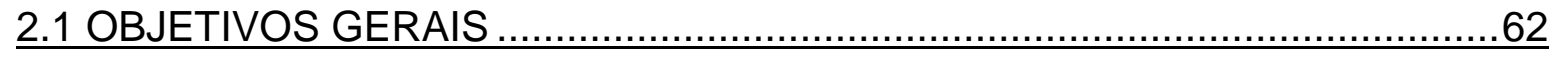




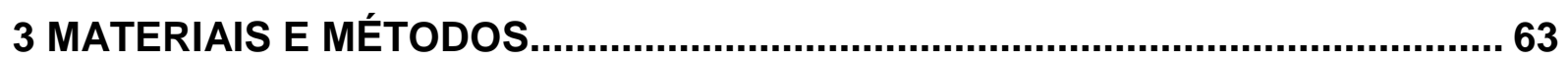

3.1 SOLVENTES E PREPARAÇÃO DE MATÉRIA-PRIMA …............................63

3.2 PROCESSOS DE DESLIGNIFICAC̣ÃO ORGANOSSOLVE ...........................63

3.2.1 CARACTERIZAÇÃO DAS DESLIGNIFICAÇÕES ORGANOSSOLVE ......................... 64

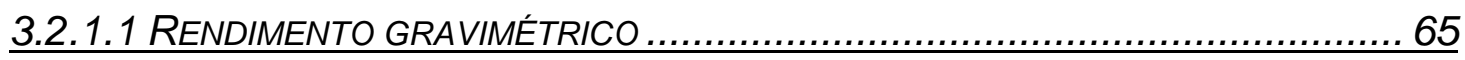

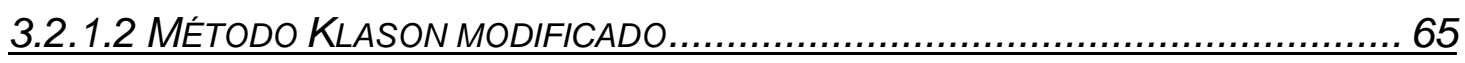

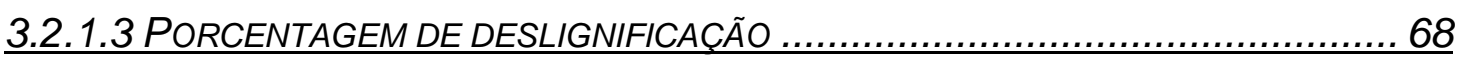

3.2.2 DETERMINAÇÃO DE PROCEDIMENTO E CONDIÇÕES REACIONAIS .......................68

3.2.3 PARÂMETROS DE SOLUBILIDADE DE LIGNINA DE BAGAÇO DE CANA-DE-AÇÚCAR . 70

3.2.3.1 DESLIGNIFICACCÕES ORGANOSSOLVE ………..................................... 70

3.2.3.2 OBTENÇÃO DOS PARÂMETROS DE SOLUBILIDADE .................................. 72

3.2.3.3 VERIFICACÃAO DOS PARÂMETROS DE SOLUBILIDADE DE LIGNINA DE BAGACCO 74

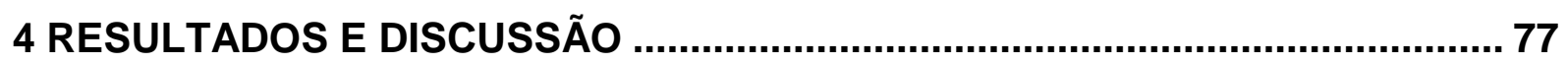

4.1 RESULTADOS DAS REAC̣ÕES DE DESLIGNIFICAC̣ÃO ……....................... 77

4.2 PARÂMETROS DE SOLUBILIDADE PARA LIGNINA DE BAGACCO ….......... 82

4.2.1 OBTENÇÃO DOS PARÂMETROS DE SOLUBILIDADE DE HANSEN PARA A LIGNINA DE

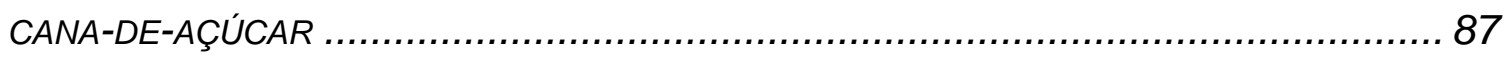

4.2.1.1 VERIFICACÃO DOS PARÂMETROS DE SOLUBILIDADE ............................. 104

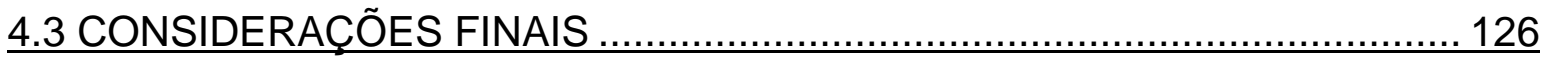

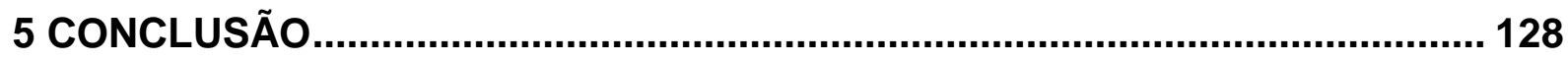

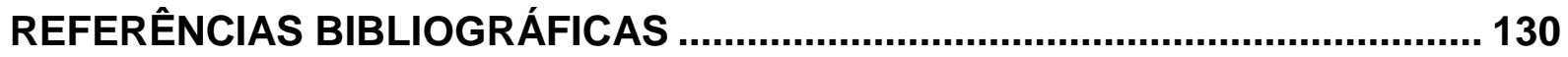




\section{INTRODUÇÃO}

\subsection{CANA-DE-ACÚCAR NO BRASIL E O MEIO AMBIENTE}

A partir da metade do século $X X$ iniciou-se a conscientização mundial a respeito da necessidade de políticas ambientais. Em nível global, o primeiro documento com estas conotações surgiu em 1972 na Conferência de Estocolmo (VIEIRA; BREDARIOL, 2006). No Brasil, as ações relacionadas à politicas ambientais iniciaram-se com a instituição da Lei da Política Nacional do Meio Ambiente, seguida pela criação do Conselho Nacional de Meio Ambiente e culminando com destaques na Constituição Federal de 1988. Contudo, nestes momentos, a matriz energética mundial ainda estava baseada exclusivamente nos combustíveis fósseis (NOVO, 2009).

Em 2008, o consumo de combustíveis oriundos do petróleo e gás natural correspondia a 55\% do consumo mundial de energia (BNDES; CGEE, 2008). Assim, com as leis ambientais, o desenvolvimento de tecnologias relacionadas a combustíveis de fontes renováveis se fez necessário. No Brasil foi criado o programa brasileiro de álcool (Proálcool), em 1975, que estabelecia a substituição parcial ou total do uso da gasolina como combustível veicular pelo etanol (BASTOS, 2007). Brasil é hoje o único país a implantar o uso em larga escala de um combustível veicular renovável em alternativa aos provenientes de petróleo (ZANIN et al., 2000).

A produção de álcool etílico pode ser feita a partir de três principais tipos fontes de carboidratos: a primeira são fontes que possuem açúcares simples, como a cana-de-açúcar (Brasil e países caribenhos) e a beterraba (Reino Unido e outros países europeus); a segunda são fontes de amidos, como o milho (EUA e países europeus) e o trigo (China e Índia); e a terceira são fontes com elevados teores de celulose, também conhecidos como biomassa lignocelulósica, como o bagaço de cana-de-açúcar e resíduos da produção de grãos (como a espiga de milho e palha de trigo), entre outras (MUSSATTO et al., 2010).

O principal setor econômico brasileiro em toda história é o setor agrícola (PEROBELLI et al., 2007). Atualmente, o mesmo está baseado na produção de grãos, como a soja e o milho (cerca de 130 milhões de toneladas em 2010), e da 
cana-de-açúcar (cerca de 720 milhões de toneladas em 2010), tanto para a produção de açúcar como a produção de etanol combustível (IBGE, 2011).

Atualmente, o principal subproduto da produção sucroalcooleira é o bagaço de cana-de-açúcar, com cerca de 180 milhões de toneladas produzidas em 2010 (de cada tonelada de cana-de-açúcar processada cerca de $250 \mathrm{Kg}$ de bagaço, com umidade de aproximadamente 50\%, são produzidos). Grande parte do bagaço de cana-de-açúcar é utilizado como combustível nas caldeiras de geração de vapor nas próprias usinas de açúcar e álcool, usado para mover a própria produção industrial ou para a venda na forma de eletricidade (ZANIN et al., 2000; NOVO et al., 2011).

Desta maneira, os subprodutos gerados pela indústria de açúcar e álcool acabam sendo um enorme excesso de biomassa vegetal que não gera produtos de maior valor agregado. No Brasil, devido à larga produção de etanol a partir da fermentação de açúcares obtidos da cana-de-açúcar, o bagaço resultante da produção sucroalcooleira tem sido uma das matrizes mais estudadas. Atualmente as utilizações do bagaço de cana-de-açúcar se limitam ao uso como combustível de caldeiras nas usinas sucroalcooleiras e também como alimento para os rebanhos (CANDIDO et al., 1999; NOVO et al., 2011), porém uma das novas áreas pesquisadas é a utilização do bagaço como insumo em um contexto de uma biorrefinaria, podendo produzir etanol de segunda geração, ou ainda outros compostos químicos com maior valor agregado.

\subsection{CARACTERIZAC̣ÃO DA CANA-DE-ACUÚCAR E DERIVADOS}

\subsubsection{CARACTERIZAÇÃO ESTRUTURAL DA CANA-DE-AÇÚCAR}

A cana-de-açúcar é uma planta composta de três partes principais: a epiderme, que recobre finamente o talo, servindo de proteção e atuando como impermeabilizante; a casca, composta de fibras lignificadas, servindo de proteção ao talo contra efeitos mecânicos externos, além de fornecer sustentação à planta; e o tecido parenquimatoso, que é composto por células com a principal função de armazenar açúcares. Existem ainda no interior do parênquima, feixes de fibras e 
vasos com a função de conduzir nutrientes e outras substâncias produzidas pela planta (TRIANA et al., 1990). A figura 1 mostra o exemplo de corte transversal do talo de uma cana-de-açúcar.

No processamento industrial da cana-de-açúcar, ocorre a separação do caldo rico em sacarose do material lignocelulósico (bagaço). O caldo é a matéria-prima para a produção de açúcar e de etanol.

Figura 01 - Corte transversal do talo de uma cana-de-açúcar.

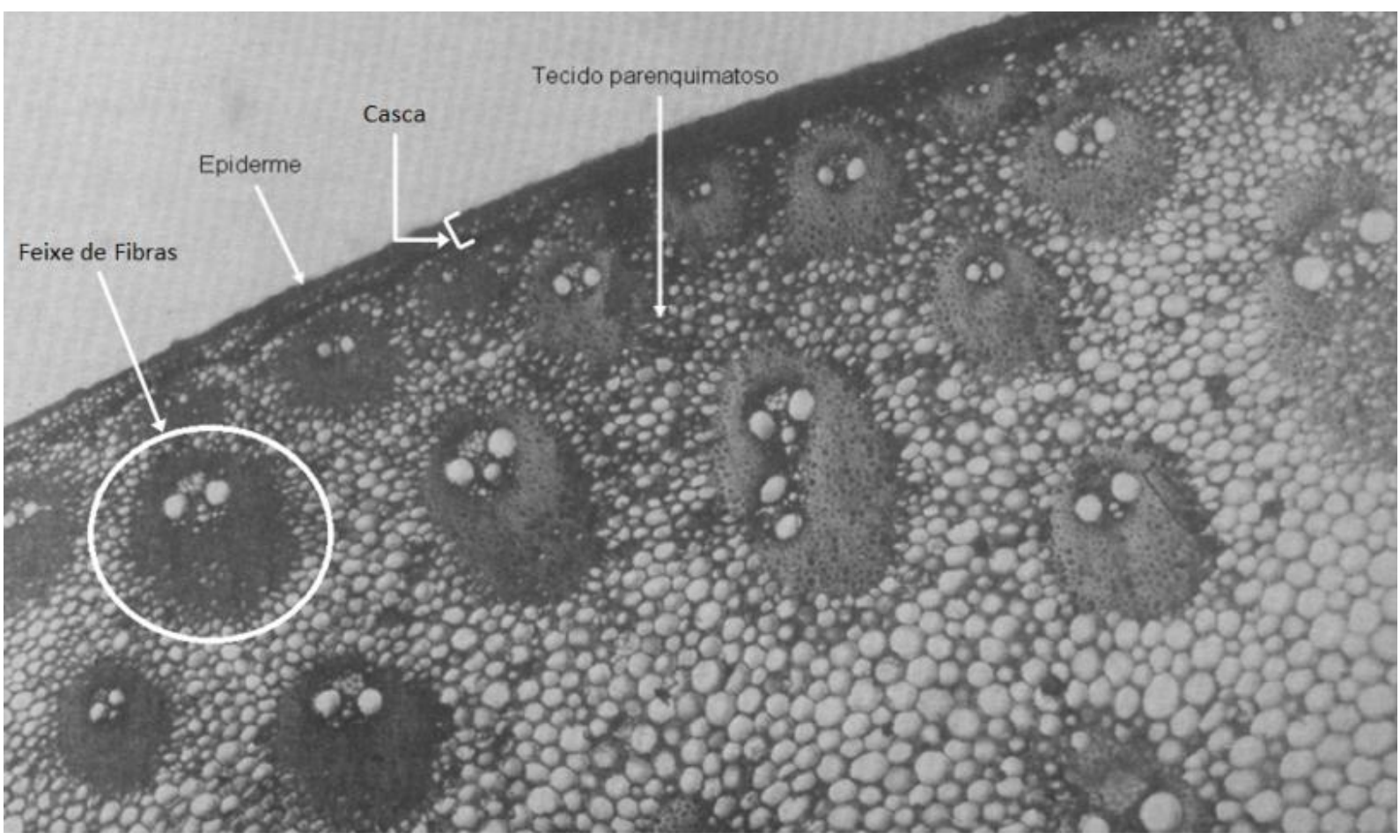

Fonte: TRIANA, O. et al. Atlas del bagazo de la caña de azucar. México: GEPLACEA / PNUD / ICIDCA, 1990. 143 p.

1.2.2 CARACTERIZAÇÃO MORFOLÓGICA E QUÍMICA DO BAGAÇO DE CANA-DE-AÇÚCAR

O bagaço é um material heterogêneo, composto principalmente da porção lignocelulósica do talo da cana de açúcar, com pequenas quantidades de palha e de bainhas, que não foram eliminadas no processo de colheita. $O$ mesmo é formado por um conjunto de fragmentos com dimensões entre $1 \mathrm{~mm}$ e $25 \mathrm{~mm}$, sendo que o tamanho destes fragmentos depende dos processos de moagem e da variedade da cana (TRIANA et al., 1990). 
Após o processo de moagem em uma usina sucroalcooleira cerca de $50 \%$ da massa do bagaço de cana-de-açúcar corresponde a umidade, $45 \%$ corresponde a estruturas fibrilares lignocelulósicas e $5 \%$ corresponde a extrativos e componentes inorgânicos. Fisicamente, a fração de estruturas fibrilares lignocellulósica é formada por uma porção de células de parênquima, ou medula, (cerca de 30 a $35 \%$, em massa seca), uma porção de células fibrilares, ou simplesmente fibras, (cerca de 55 a $60 \%$, em massa seca) e por outros componentes (cerca de 10 a $15 \%$, em massa seca) (TRIANA et al., 1990). A figura 2 mostra a diferença visual das porções de medula e fibras do bagaço de cana-de-açúcar.

Figura 02 - Características visuais das frações do bagaço de cana-de-açúcar. a) Fração fibra;

b) Fração medula.
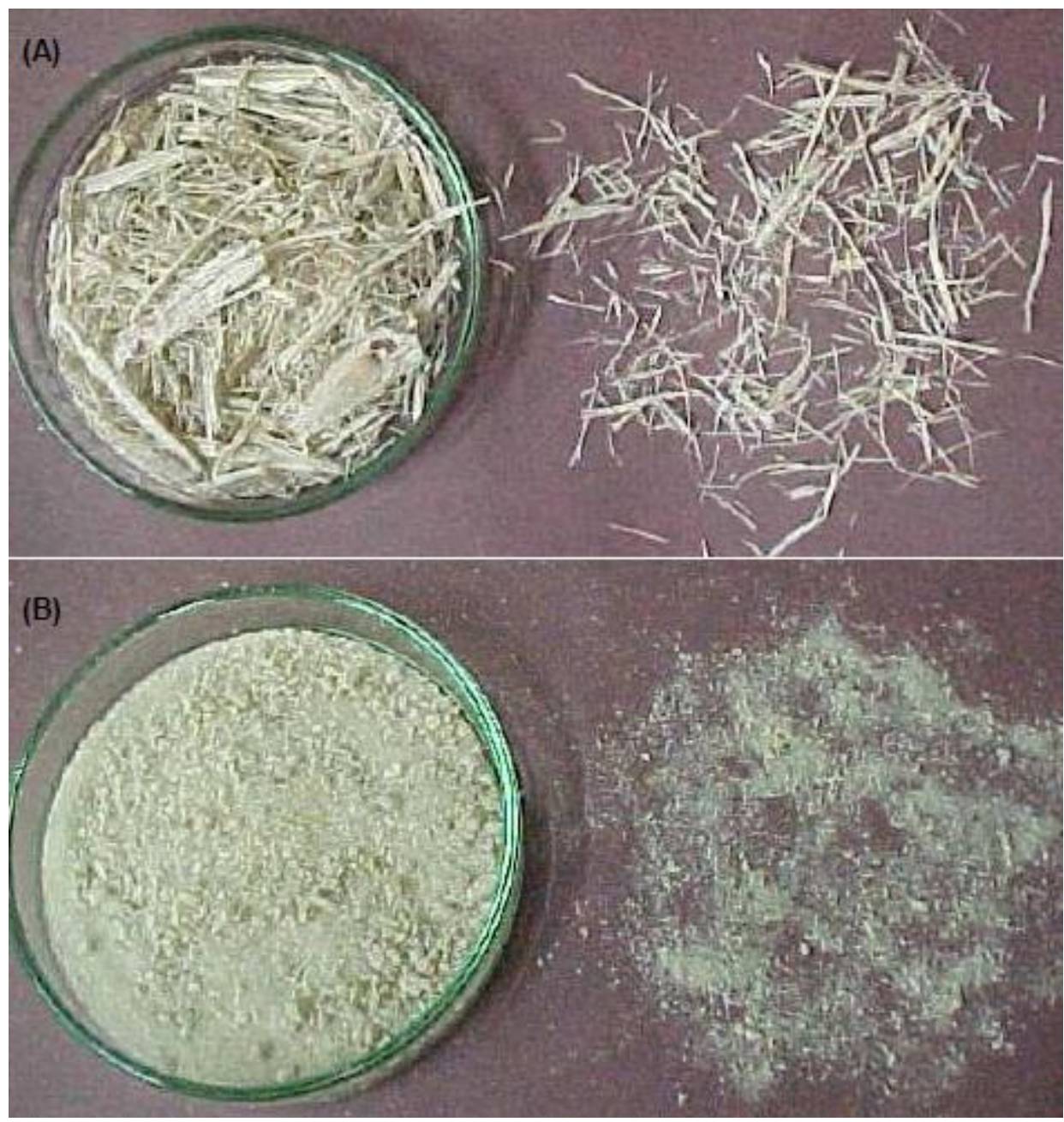

Fonte: MARABEZI, K. Estudo sistemático das reações envolvidas na determinação dos teores de Lignina e Holocelulose em amostras de Bagaço e Palha de Cana-de-Açúcar. 2009. 142 (MS). Instituto de Química de São Carlos, Universidade de São Paulo, São Carlos.

Em relação à composição química, o bagaço é composto por quatro classes de compostos orgânicos principais: a lignina (cerca de 20\% em base seca), a celulose (cerca de $44 \%$ em base seca), as hemiceluloses (cerca de $26 \%$ em base 
seca) e os extrativos (cerca de $4 \%$ em base seca), sendo o restante compostos inorgânicos (TRIANA et al., 1990). Devido à grande heterogeneidade química desta biomassa vegetal há uma grande possibilidade de valorização, no contexto de biorrefinaria, após etapas de fracionamento do material. Uma das possibilidades é a obtenção dos monossacarídeos da fração polissacarídica e a conversão dos mesmos em etanol por fermentação alcoólica. Deste modo, verifica-se que é necessária a separação das frações do bagaço de cana em frações mais homogêneas (NOVO et al., 2011). Alguns processos são conhecidos para realizar a separação das frações da biomassa vegetal, como a pré-hidrólise, processo para separação das hemiceluloses, ou a polpação (deslignificação), processo usado para retirar a lignina (PASQUINI et al., 2005)

\subsubsection{CELULOSE}

A celulose corresponde à fração do bagaço de cana-de-açúcar mais estudada, sendo a mais homogênea em termos químicos. A celulose foi primeiramente descrita em 1838 pelo químico francês Anselme Payer. O mesmo determinou a formula molecular mínima por análise elementar como sendo $\mathrm{C}_{6} \mathrm{H}_{10} \mathrm{O}_{5}$ e observou sua isomeria com o amido (KLEMM et al., 2005).

A celulose é um polissacarídeo composto de unidades de anidroglicose, conectadas por ligações $\beta-1,4$ glicosídicas resultando em macromoléculas de alta massa molar. A figura 3 mostra uma representação da estrutura molecular da celulose. As cadeias de celulose, nas paredes celulares, se arranjam de uma forma muito compacta, apresentando regiões cristalinas, devido ao grande número de hidroxilas, 3 para cada unidade de anidroglicose, o que permite a elevada interação intermolecular e intramolecular através de ligações de hidrogênio. Para a ocorrência de uma acomodação termodinamicamente favorável das ligações de hidrogênio, o segundo anel de anidroglicose é girado em $180^{\circ}$, formando o dímero conhecido por celobiose e que é a unidade repetitiva das cadeias poliméricas da celulose. A figura 4 mostra uma representação das interações intramoleculares e intermoleculares de cadeias de celulose (KLEMM et al., 2005; GURGEL, 2007; MARABEZI, 2009). 
Figura 03 - Representação de uma molécula de celulose.<smiles>OC1O[C@H](O)[C@@H](O)[C@H](O)[C@H]1O</smiles>

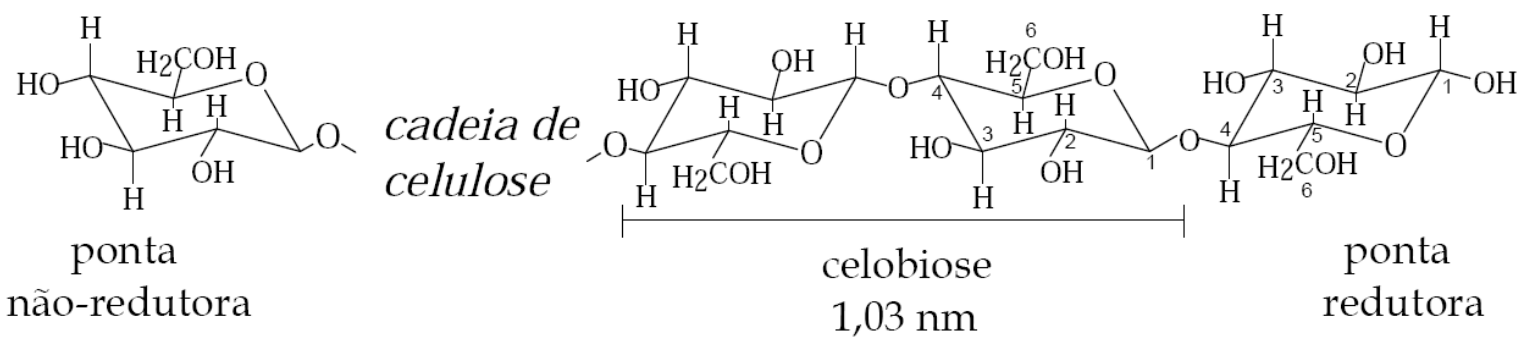

Fonte: FENGEL, D.; WEGENER, G. Wood : chemistry, ultrastructure, reactions. Berlin: W. de Gruyter, 1984. (Adaptado)

Figura 04 - Representação das ligações de hidrogênio intra e intermolecular da celulose.

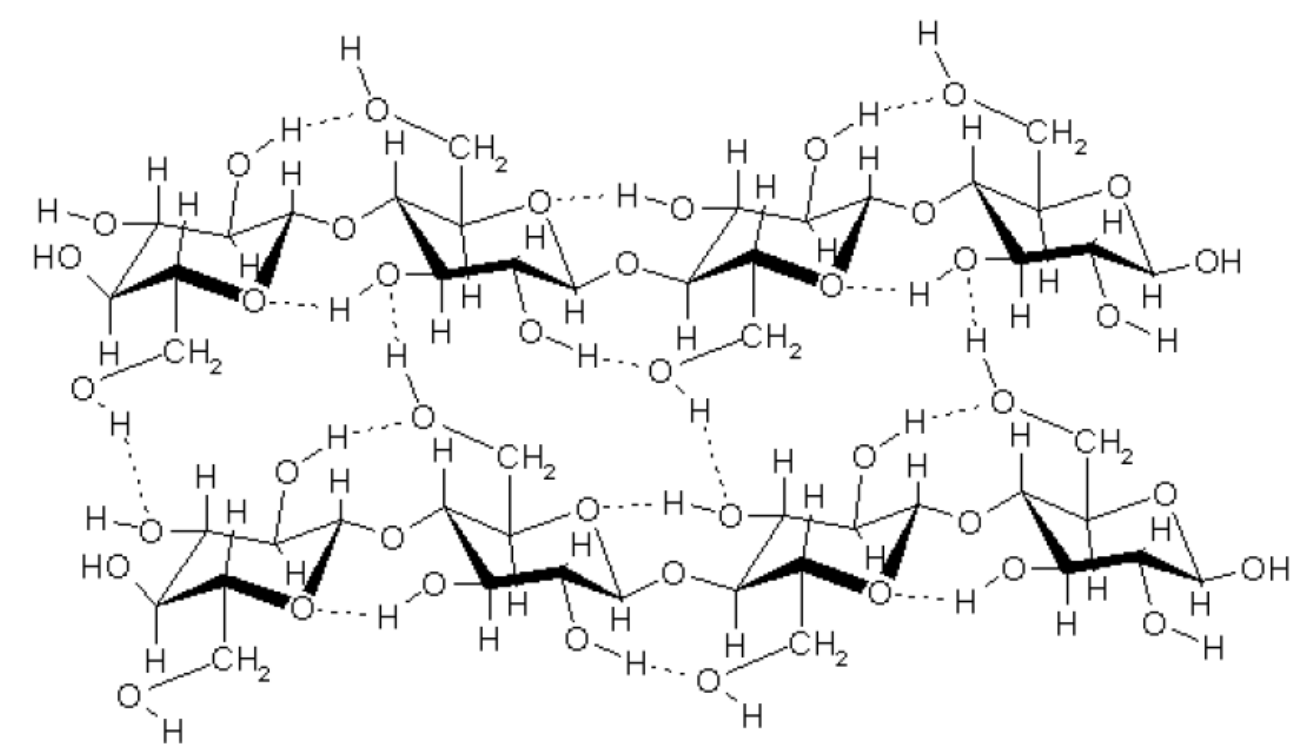

Fonte: FENGEL, D.; WEGENER, G. Wood : chemistry, ultrastructure, reactions. Berlin: W. de Gruyter, 1984. (Adaptado)

Diferentes materiais lignocelulósicos possuem cadeias celulósicas de comprimentos diferenciados, como por exemplo, polpas de madeira possuem em média um número de unidades de anidroglicose de 300 a 1700 unidades, enquanto que fibras como o algodão possuem cadeias muito maiores, podendo chegar a 10.000 unidades de anidroglicose, dependendo do tratamento pela qual é obtida, o que permite diversos usos diferenciados para os diferentes tipos de celulose. Uma cadeia de 20 a 30 unidades de anidroglicose já possui todas as características apresentadas por uma cadeia de celulose (KLEMM et al., 2005; GURGEL, 2007). 
Pode-se observar, ainda, na figura 3 que as cadeias de celulose possuem terminações diferentes em sua cadeia, uma terminação não redutora, na qual o carbono $\mathrm{C}-4$ possui sua hidroxila original, e uma terminação redutora, na qual o carbono $\mathrm{C}-1$ se apresenta em estrutura de hemiacetal. A estrutura hemiacetal da unidade redutora, em solução aquosa, está em equilíbrio com a correspondente estrutura de ressonância na qual o carbono $\mathrm{C}-1$ é um aldeído, como se pode observar na figura 5 (KLEMM et al., 2005; GURGEL, 2007).

Figura 05 - Estruturas de ressonância da terminação redutora da estrutura da celulose.

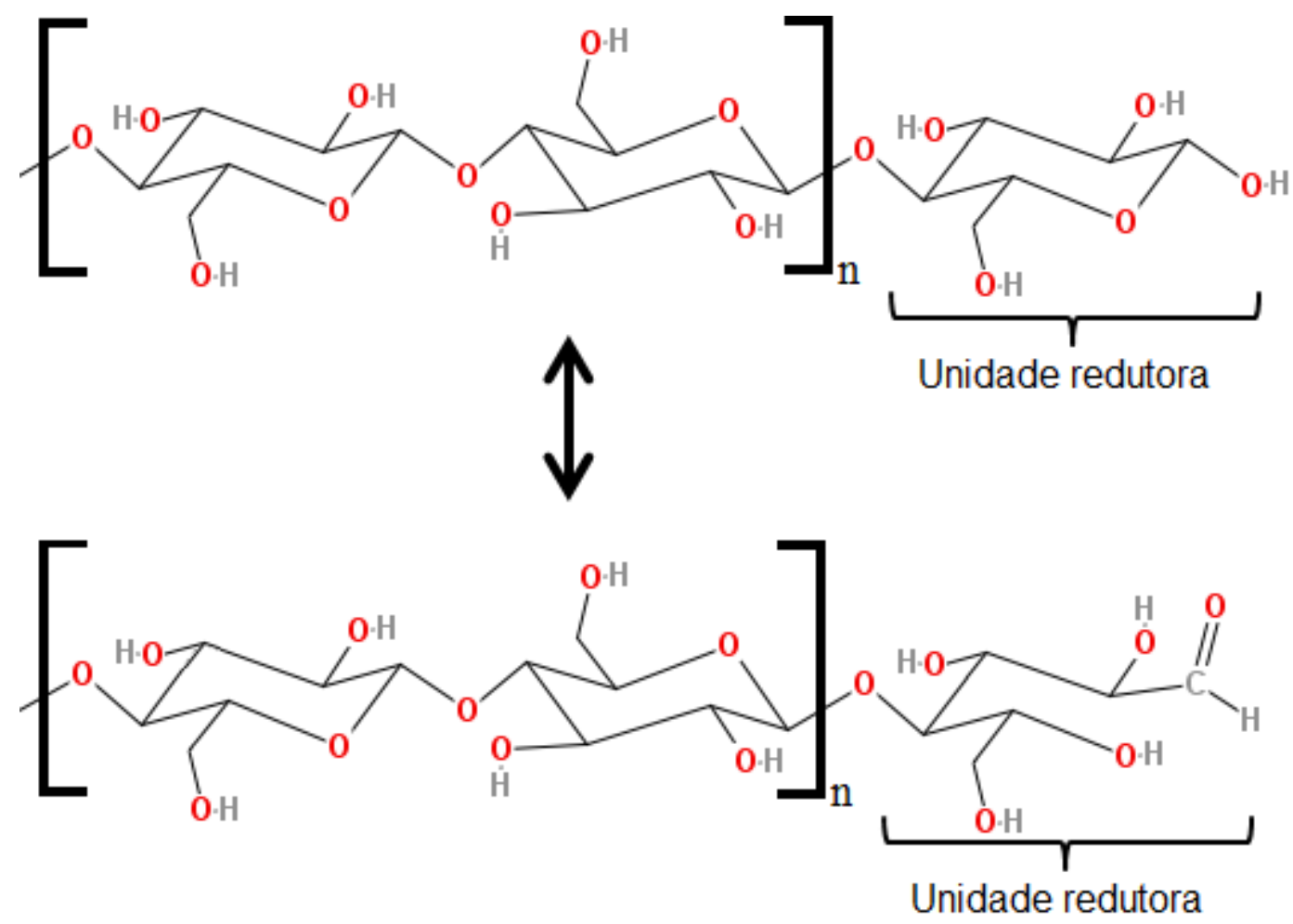

Os grupos hidroxila nos carbonos C-2 e C-3, que são carbonos secundários, estão dispostos na estrutura de cadeira de modo equatorial. Esta disposição possibilita a formação de ligações de hidrogênio intramoleculares, entre unidades de anidroglicose adjacentes, e intermoleculares, entre cadeias de celulose diferentes, permitindo a formação tanto de estruturas com alto nível organizacional, cristalinas, quanto de estruturas de baixo nível organizacional, amorfas (KLEMM et al., 2005; GURGEL, 2007; MARABEZI, 2009).

Para que o processo de dissolução ocorra, as macroestruturas de celulose (fibras e estruturas fibrilares) têm que ser desorganizadas, para isso, outras moléculas que tem a capacidade de interagir fortemente com as cadeias de celulose 
têm que ser "inseridas", resultando na solvatação e consequente afastamento das macromoléculas (MARABEZI, 2009).

Uma outra maneira de promover a solubilização da celulose é sua conversão a derivados, dentre os quais se incluem os ésteres, como acetato de celulose ou os éteres, como metilcelulose ou carboximetilcelulose. A dissolução pode ocorrer também em ácidos concentrados, porém esta opção pode levar a hidrólise das ligações glicosídicas, gerando subprodutos de degradação (FENGEL; WEGENER, 1984).

Em termos estruturais, a celulose é o componente que se apresenta em maior quantidade das paredes celulares, e devido ao seu aspecto fibrilar fornece resistência à estrutura. Desta maneira, a celulose pode ser considerada como o "esqueleto" principal da planta, rodeada e incrustrada pelas frações de hemiceluloses e de lignina (CURVELO, 1992; EK et al., 2009).

\subsubsection{HEMICELULOSES}

As hemiceluloses, ou polioses, são polissacarídeos compostos por diversas unidades de açúcar, em proporções que também são variadas, ao contrário da celulose que é formada exclusivamente por unidades de D-glicose. Os monômeros presentes nas polioses são $\beta$-D-xilose, $\beta$-D-manose, $\beta$-D-glicose, $\alpha$-L-arabinose, $\alpha$ $D$-galactose, ácido $\beta$-D-glicourônico, ácido $\beta$-D-galactourônico e ácido $\alpha$-D-4metilglicourônico, mostrados na figura 6 (FENGEL; WEGENER, 1984). Pode-se observar que dentre as unidades existem pentoses, monossacarídeos com cinco átomos de carbono, e hexoses, monossacarídeos com seis átomos de carbono, o que altera muito as propriedades das macromoléculas formadas pelos mesmos.

As diversas fontes lignocelulósicas, como madeiras de folhosas ou de coníferas, possuem porcentagens diferentes de polioses totais e também porcentagens diferentes de açúcares que os formam. O bagaço de cana-de-açúcar possui principalmente xilose como açúcar constituinte das polioses (FENGEL; WEGENER, 1984). 
Figura 06 - Representação das moléculas dos açúcares precursores das polioses.

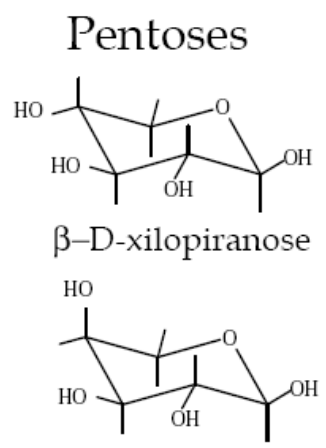

$\alpha$-L-arabinopiranose

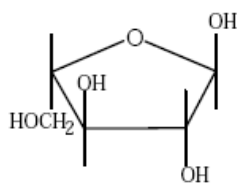

$\alpha$-L-arabinofuranose
Hexoses

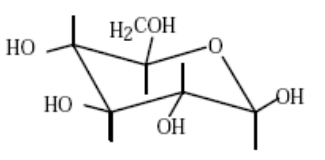

$\beta$-D-glicopiranose

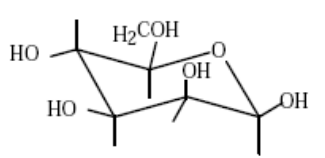

$\beta$-D-manopiranose

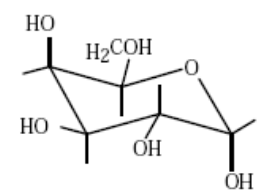

$\alpha$-D-galactopiranose
Ácidos hexurônicos

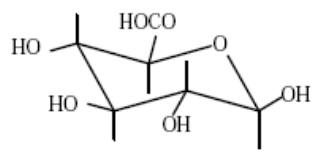

ácido $\beta-\mathrm{D}$-glicourônico

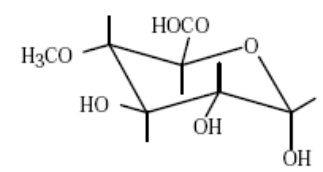

ácido $\alpha-\mathrm{D}-4-\mathrm{O}-\mathrm{metil}$-glicourônico

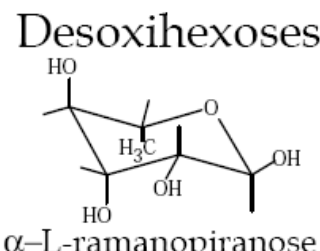

$\alpha$-L-ramanopiranose

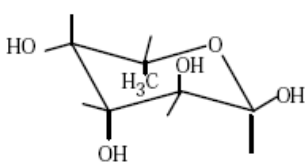

$\alpha-$ - fucopiranose

Fonte: FENGEL, D.; WEGENER, G. Wood : chemistry, ultrastructure, reactions. Berlin: W. de Gruyter, 1984. (Adaptado)

Diferentemente da celulose que é uma estrutura longa e sem ramificações, as hemiceluloses se apresentam na forma de cadeias mais curtas e com diversas ramificações. Em termos estruturais, as hemiceluloses possuem a função de "intermediar" as frações de celulose e de lignina, interagindo com ambas. A similaridade química e estrutural entre os dois polissacarídeos, celulose e hemiceluloses, seria o responsável por suas íntimas associações, visto que ambos possuem a característica da formação de ligações de hidrogênio. Da mesma maneira, a associação entre as hemiceluloses e a lignina ocorre devido ao caráter amorfo de ambos, assim a massa molar menor das hemiceluloses permitiria, por sua vez, a posterior deposição de lignina (CURVELO, 1992; EK et al., 2009). Na figura 7 pode-se observar alguns dos modelos da associação entre a hemiceluloses, a celulose e a lignina nas estruturas macromoleculares. 
Figura 07 - Modelos de associação dos componentes celulares macromoleculares. a) Preston

(1962); b) Marchessault (1964); c) Kerr e Göring (1975); d) Fengel (1970); e) Salmén and Olsson (1998).
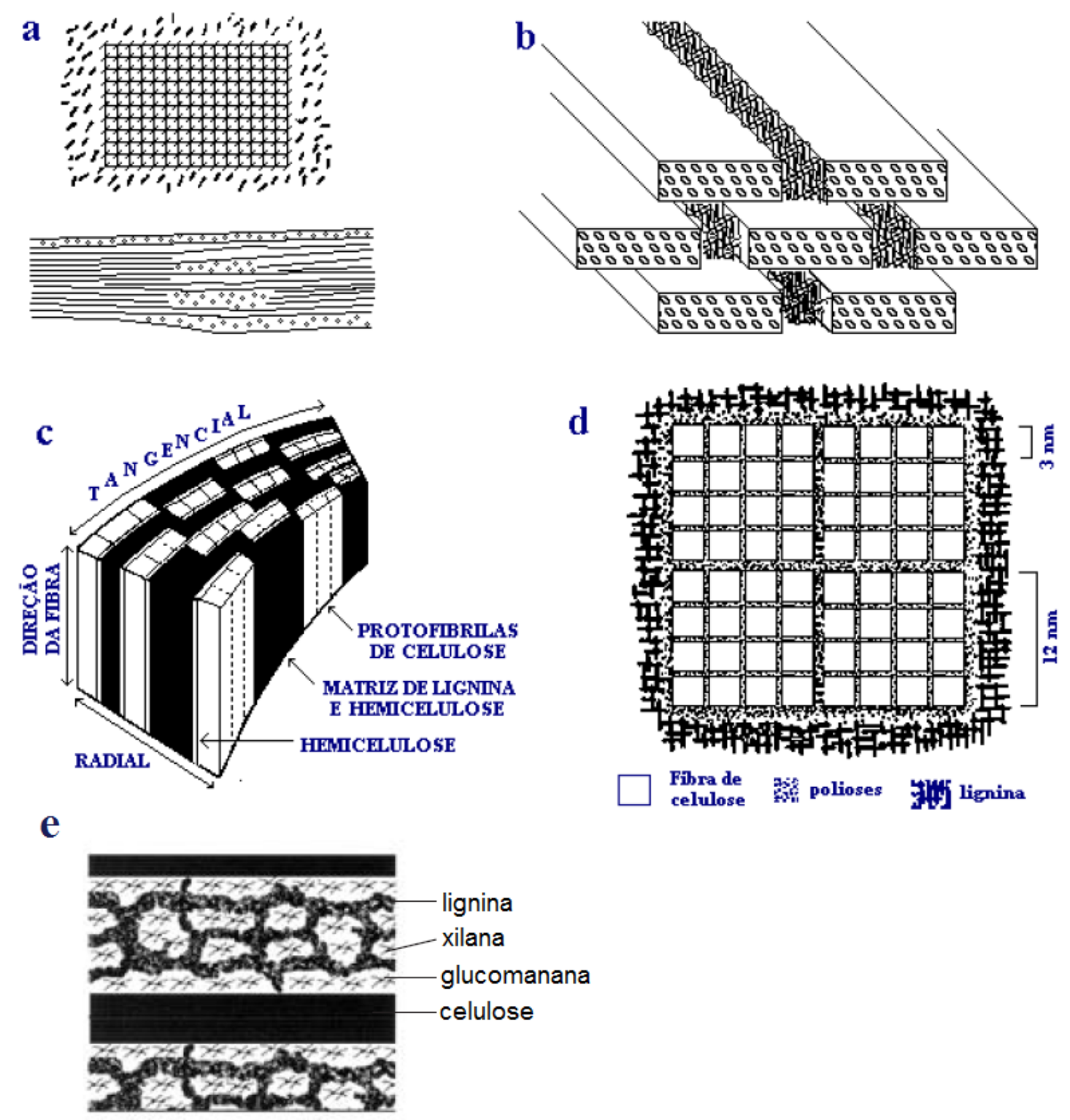

Fonte: a-d - FENGEL, D.; WEGENER, G. Wood : chemistry, ultrastructure, reactions. Berlin: W. de Gruyter, 1984. 613p.; e - HEITNER, C. et al. Lignin and lignans advances in chemistry. Boca Raton, FL: Taylor \& Francis, 2010. 629 p. (Adaptado)

\subsubsection{LIGNINA}

A palavra lignina é derivada do latim "lignum" que significa madeira, e de fato a lignina é um dos compostos principais na formação de tecidos de madeira. Entretanto a lignina não é um composto exclusivo de madeiras, ocorrendo em todos 
os vegetais vasculares, porém em porcentagens muito menores do que em madeiras (de 1-20\% em comparação com teores de até 39\%) (BALOGH, 1989; EK et al., 2009).

A lignina pode ser isolada como produto secundário da produção de polpa celulósica, por via química, já que por vias biológicas a lignina é degradada a outros produtos. Estima-se que a quantidade de lignina extraída em todo o mundo seja de mais de 70 milhões de toneladas por ano, porém menos de $2 \%$ desta quantidade é efetivamente recuperada e utilizada em produtos de mercado. Atualmente, a principal utilização da lignina é seu emprego como fonte de energia, através da queima da mesma. No processo Kraft (processo mais utilizado na obtenção de polpas para a indústria de papel e celulose), por exemplo, a maior parte da lignina presente no licor negro é queimada para geração de energia e recuperação dos reagentes inorgânicos utilizados, sendo assim um importante fator econômico para a indústria papeleira (GEORG, 2000; BELGACEM; GANDINI, 2008; MARABEZI, 2009).

Em termos morfológicos, a lignina é uma substância amorfa localizada na lamela média, bem como na parede secundária, sendo o último componente incorporado na parede celular durante o crescimento celular, interpenetrando as fibrilas celulósicas e "colando" células diferentes. Esta interpenetração resulta no fortalecimento e enrijecimento das paredes celulares sendo, portanto, o componente responsável pela resistência mecânica à compressão dos vegetais. A lignina também atua no transporte de água, nutrientes e metabólitos por tornar a parede celular hidrofóbica (inibe o inchamento de uma célula em água), podendo ser considerada a chave para a evolução das plantas vasculares. Ademais, a lignina atua na proteção a planta contra microorganismos, pois dificulta a penetração das enzimas degradadoras dos polissacarídeos (FENGEL; WEGENER, 1984; EK et al., 2009).

A porcentagem de lignina presente nas matérias-primas vegetais apresenta uma grande variação, passando de uma quantidade quase nula em matérias-primas fibrosas como o algodão a quantidades de até 39\%, dependendo do tipo de madeira. Visto que a madeira é um material muito comum, e devido ao alto conteúdo de lignina na madeira, a lignina é um dos biopolímeros mais abundantes na Terra (BALOGH, 1989; EK et al., 2009). 
A lignina é uma macromolécula muito complexa, composta por unidades fenilpropânicas. A sua formação se dá pela polimerização desidrogenativa principalmente das unidades de álcoois cumarílico (unidade p-hidroxifenila), coniferílico (unidade guaiacila) e sinapílico (unidade siringila), sendo que os três se diferenciam com relação ao número de grupos metoxilas $\left(-\mathrm{OCH}_{3}\right)$ ligados ao anel aromático. Na figura 8 pode-se observar a unidade fenil-propânica e as estruturas dos principais álcoois precursores. Outras unidades também presentes na estrutura da lignina são apresentadas na figura 9 (BALOGH, 1989; EK et al., 2009; MARABEZI, 2009).

Figura 08 - Unidade básica fenil-propânica e álcoois precursores da lignina.

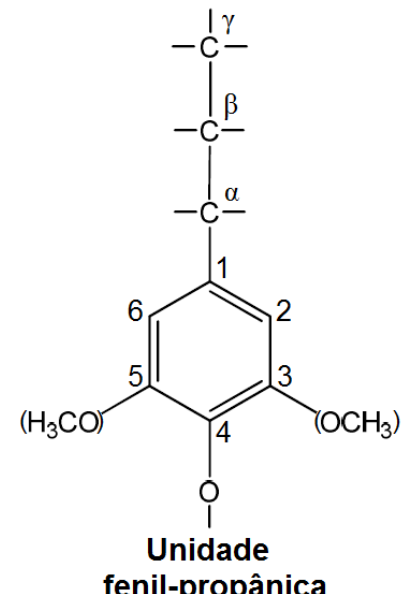

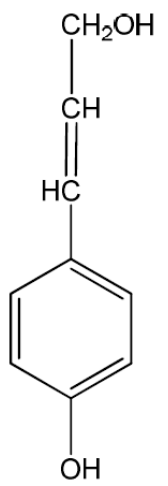

Álcool p-cumarílico<smiles>OCC=Cc1ccc(O)c(Cl)c1</smiles>

Álcool coniferílico<smiles>COc1cc(C=CCO)cc(OC)c1O</smiles>

Álcool sinapílico

Fonte: FENGEL, D.; WEGENER, G. Wood : chemistry, ultrastructure, reactions. Berlin: W. de Gruyter, 1984. (Adaptado)

Figura 09 - Exemplos de unidades menos usuais de precursores da lignina.

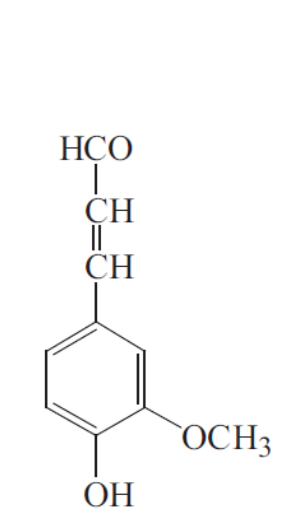

Coniferaldeído

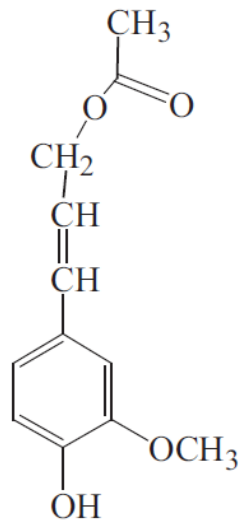

Álcool coniferílico acetilado<smiles>COc1cc(C=CC(=O)O)ccc1O</smiles>

Ácido ferúlico

Fonte: EK, M.; GELLERSTEDT, G.; HENRIKSSON, G. Wood Chemistry and Wood Biotechnology. Germany: 'DE GRUYTER', 2009. 308 p.

Devido ao grande número de combinações possíveis entre as unidades básicas precursoras, a estrutura "in situ" da lignina não pode ser definida com certeza, desta maneira realizaram-se estudos visando esclarecer a estrutura da 
lignina empregando métodos de isolamento suaves e assim, preservando ao máximo as ligações presentes na protolignina (LIN; DENCE, 1992). Na figura 10 observa-se uma estrutura sugerida para lignina de madeiras de coníferas (madeiras de arvores pertencentes à subdivisão das gimnospermas). A lignina em madeiras de coníferas, de madeiras folhosas (madeiras de arvores pertencentes à subdivisão das angiospermas dicotiledôneas) e em angiospermas monocotiledôneas (gramíneas entre outras plantas) se diferencia principalmente no conteúdo de grupos metoxilas, ou seja, existe uma diferença na proporção entre as unidades básicas que são polimerizadas em cada tipo de biomassa vegetal. Desta maneira, pode-se classificar a biomassa e suas ligninas pela razão entre suas unidades precursoras básicas (MARABEZI, 2009).

Figura 10 - Estrutura sugerida para lignina de madeiras moles.

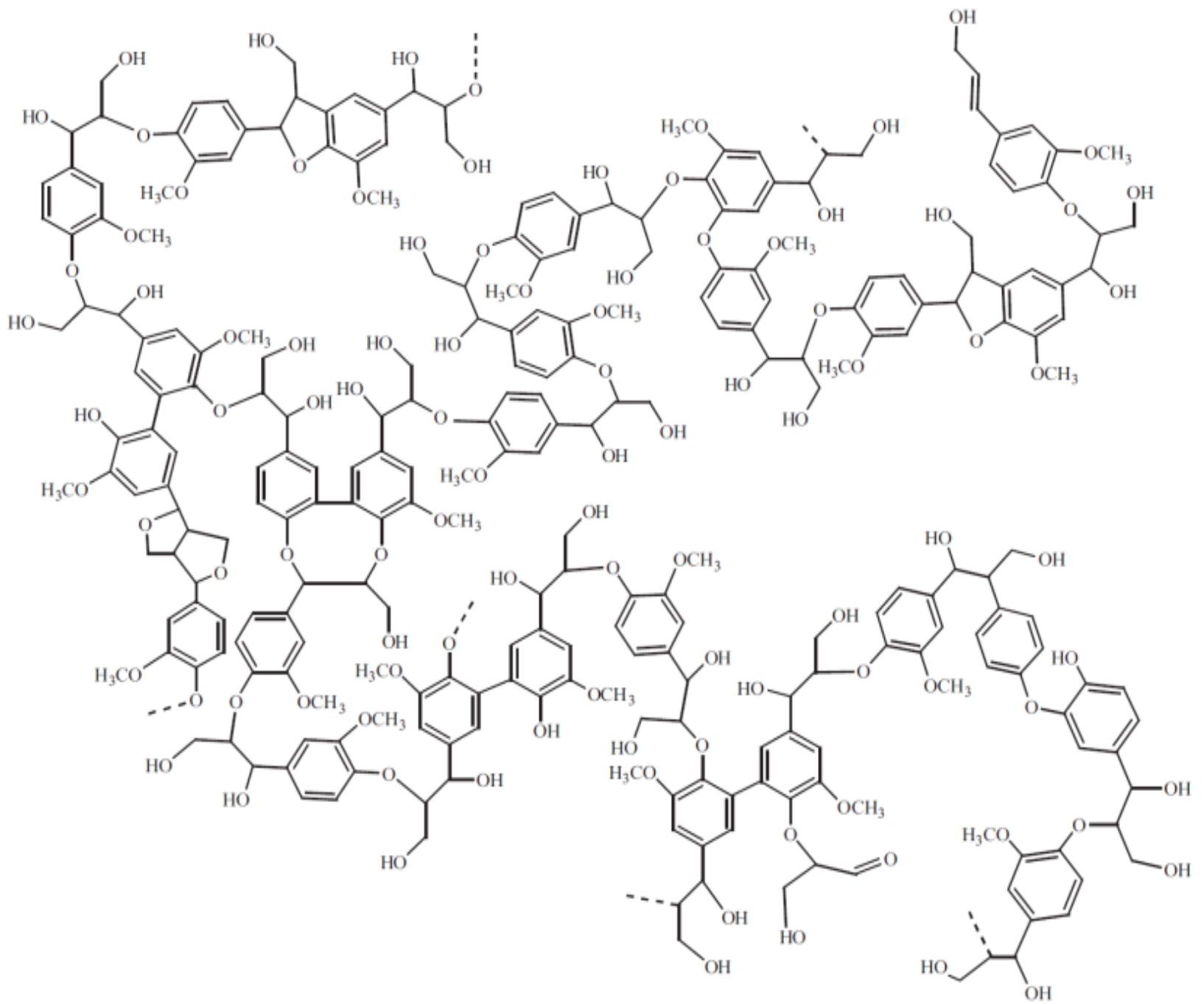

Fonte: EK, M.; GELLERSTEDT, G.; HENRIKSSON, G. Wood Chemistry and Wood Biotechnology. Germany: 'DE GRUYTER', 2009. 308 p. 
$\mathrm{Na}$ tabela 1 pode-se verificar a composição da lignina em diferentes tipos de biomassa vegetal, expressa em termos de unidades precursoras. Coníferas possuem ligninas mais homogêneas, contendo quase que exclusivamente unidades do tipo guaiacila (lignina tipo G); ligninas de folhosas possuem quantidades aproximadamente equivalentes de grupos tipo guaiacila e siringila, e pequenas quantidades de grupos p-hidroxifenila (lignina tipo GS); gramíneas apresentam ligninas com uma maior quantidade de unidades do tipo $p$-hidroxifenila do que em madeiras de coníferas ou de folhosas, porém sempre em menor proporção do que as outras unidades, normalmente a unidade predominante são as guaiacilas (ligninas do tipo HGS) (EK et al., 2009; HEITNER et al., 2010).

Tabela 01 - Composição de monômeros de lignina em diferentes plantas

\begin{tabular}{cccc}
\hline Planta & p-hidroxifenila (\%) & guaiacila (\%) & siringila (\%) \\
\hline Coníferas & $<5$ & $>95$ & $0-$ traços \\
Folhosas & $0-8$ & $25-50$ & $46-75$ \\
Gramíneas & $5-33$ & $33-80$ & $20-54$ \\
\hline
\end{tabular}

Fonte: EK, M.; GELLERSTEDT, G.; HENRIKSSON, G. Wood Chemistry and Wood Biotechnology. Germany: 'DE GRUYTER', 2009. 308 p. (Adaptado)

Como se pode observar na figura 10, as ligninas possuem diferentes grupos funcionais, sumarizados na figura 11. Além das ligações mostradas na figura 11, as ligninas ainda podem realizar ligações aril-éter nos carbonos $C-\alpha$ e $C-\gamma$, além de ligações do tipo éster no carbono $\mathrm{C}-\mathrm{Y}$ com outras estruturas que possuem o grupo ácido carboxílico, para o caso de reações com a lignina (HEITNER et al., 2010). 
Figura 11 - Possíveis grupos funcionais presentes em uma lignina.

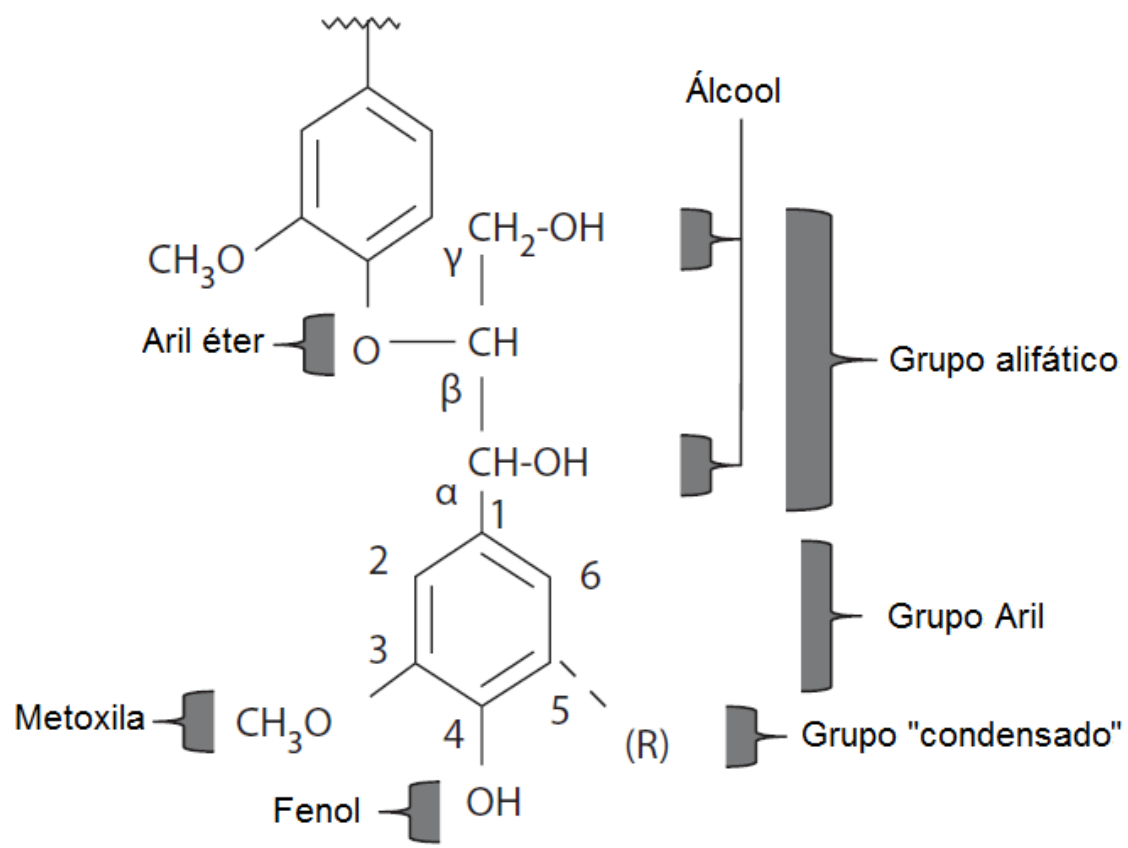

Fonte: HEITNER, C. et al. Lignin and lignans advances in chemistry. Boca Raton, FL: Taylor \& Francis, 2010. 629 p. (Adaptado)

\subsection{CARACTERIZAÇÃO DE LIGNINAS NO ESTADO SÓLIDO}

A caracterização de ligninas no estado sólido pode ser realizada por meio de diferentes técnicas analíticas. As principais análises instrumentais utilizadas com este intuito são a espectroscopia no infravermelho com transformada de Fourier (FTIR), métodos de microscopia, como microscopia de ultravioleta, microscopia de interferência e microscopia de elétrons, a espectroscopia Raman, as análises térmicas, como TG, DTA e DSC, e a pirólise acoplada com cromatografia gasosa e com espectroscopia de massas, podendo ainda haver outras, como técnicas de análise de superfície e análises de ressonância magnética nuclear, além de outras técnicas menos usuais (LIN; DENCE, 1992; HU, 2008).

Com cada uma destas análises pode-se obter diferentes informações para a caracterização das ligninas isoladas dos materiais lignocelulósicos. Utilizando a técnica de FTIR é possível obter informações da presença de grupos funcionais, como a presença de uma carbonila, sendo que dependendo da posição do pico isto indica se é uma carbonila de éster, de ácido carboxílico, de amida e etc.. Ademais, a 
análise por infravermelho ainda pode fornecer algumas informações a respeito da razão entre os precursores de lignina e como estes estão interligados, por exemplo, o pico em $1166 \mathrm{~cm}^{-1}$, que corresponde a ligação $\mathrm{C}-\mathrm{O}$ em grupos ésteres conjugados, é tipicamente presente em ligninas do tipo HGS (com elevado teor de precursor $p$-hidroxifenila, com relação aos outros tipos de lignina). Outro exemplo é o pico entre 1593 e $1605 \mathrm{~cm}^{-1}$, que corresponde a vibrações do esqueleto aromático mais o estiramento da ligação $\mathrm{C}=\mathrm{O}$, que indica a presença de um número superior de unidades de siringila do que de unidades de guaiacila, além de indicar a presença de mais unidades de guaiacila ligadas entre si do que de unidades de guaiacila eterificadas. Tabelas com a interpretação dos picos de espectroscopia no infravermelho podem ser encontradas na literatura, especificamente para análises de lignina (LIN; DENCE, 1992).

Com as análises de microscopia, é possível obter informações sobre a concentração de lignina no material lignocelulósico analisado, a porosidade deste material, além da distribuição da lignina nas paredes celulares, dependendo da técnica instrumental utilizada. De modo geral, os três tipos de microscopia, de ultravioleta, de interferência e de elétrons, fornecem a concentração de lignina, porém de maneiras diferentes. Para a micrografia de ultravioleta, além da concentração de lignina é possível se obter informações a respeito da distribuição da lignina nas paredes celulares, ademais com esta técnica pode-se obter os espectros de absorção no ultravioleta, que podem variar com a quantidade de lignina presente na área analisada. Para a micrografia de interferência, pode-se obter o índice de refração da amostra, o que por sua vez permite o cálculo da concentração de lignina, e a porosidade relativa do material, o que também permite se determinar a concentração de lignina na amostra. Já para a microscopia de elétrons, pode-se obter uma caracterização mais precisa da distribuição da lignina da parede celular, o que por sua vez permite o cálculo da concentração de lignina (LIN; DENCE, 1992; $\mathrm{HU}, 2008)$.

De forma complementar às análises de espectroscopia no infravermelho das ligninas, as análises de espectroscopia Raman dos materiais lignocelulósicos podem fornecer informações a respeito de modos vibracionais de ligações químicas específicas da lignina, isto ocorre pois em algumas faixas do espectro nas quais não há contribuição das hemiceluloses e da celulose, podendo-se assim observar somente picos referentes a modos vibracionais da lignina. Existem, porém, outras 
regiões nas quais existem contribuições das três frações, assim, em alguns casos, realiza-se a subtração do espectro do material lignocelulósico por um do material completamente deslignificado e considera-se que havendo a remoção de ligninas, a diferença corresponde ao espectro da lignina. Este método não é completamente efetivo, já que durante o processo de deslignificação pode haver a remoção de outras estruturas que também poderiam contribuir para o espectro Raman (LIN; DENCE, 1992; HU, 2008).

As análises térmicas, por sua vez, podem fornecer informações a respeito de fenômenos como a degradação, oxidação, redução, evaporação, sublimação e qualquer outro fenômeno ligado à variação de temperatura de polímeros (como a transição vítrea), além de informações a respeito da entalpia relacionada a esses fenômenos. Assim, para ligninas é possível se inferir pelo uso destas técnicas informações como estabilidade, grau de intercruzamento das cadeias poliméricas, a transição vítrea e capacidade térmica da lignina (LIN; DENCE, 1992; MARABEZI, 2009).

A técnica de pirólise acoplada com cromatografia gasosa e com espectroscopia de massas aplicada à amostras de material lignocelulósico, fornece informações a respeito das quantidades dos três precursores principais que formam a lignina, das porcentagens de lignina residual em polpas, além da diferenciação e identificação de ligninas obtidas por diferentes métodos de extração. Com a utilização da cromatografia gasosa acoplada a pirólise de material lignocelulósico é possível se separar os produtos de degradação provenientes dos polissacarídeos dos produtos de degradação da lignina, podendo-se desta maneira analisar a lignina do material lignocelulósico "in natura", sem processos de remoção adicionais. Utilizando condições apropriadas, a pirólise de lignina, mesmo na presença de carboidratos, fornece um padrão característico de produtos fenólicos correspondentes aos diferentes precursores, nos quais as cadeias laterais das unidades fenil-propanicas de lignina foram completamente removidas ou reduzidas a apenas um ou dois carbonos (LIN; DENCE, 1992). 


\subsection{CARACTERIZAÇÃO DE LIGNINAS EM SOLUÇÃO}

Como o próprio nome indica, as técnicas de caracterização de lignina em solução se aplicam a quaisquer amostras que sejam solúveis, independentemente do método de extração. Contudo, uma das desvantagens de algumas técnicas de caracterização em solução é que a lignina é miscível em poucos solventes os quais nem sempre são compatíveis com os métodos analíticos. Entretanto, historicamente, as análises por via úmida foram fundamentais para a consolidação da área de ligninas.

As análises instrumentais de lignina em solução mais utilizadas são a espectrofotometria no ultravioleta (UV), a espectroscopia no infravermelho com transformada de Fourier (FTIR), ressonância magnética nuclear, tanto de carbono$13\left(\right.$ NMR ${ }^{13} \mathrm{C}$ ) quanto de prótons (NMR ${ }^{1} \mathrm{H}$ ), além de NMR de outros núcleos, e análise de distribuição de massas molares por cromatografia de permeação em gel (GPC), além de outras análises.

Pelo fato da lignina necessariamente possuir uma grande quantidade de anéis aromáticos, e consequentemente permite realizar transições de níveis eletrônicos ao absorver radiação no ultravioleta, historicamente a análise de espectrofotometria no ultravioleta é uma das técnicas mais utilizadas e úteis na análise qualitativa e, principalmente, quantitativa da lignina. A utilização desta técnica permite a obtenção de informações como a concentração de lignina na solução, e em alguns casos a concentração de alguns grupos funcionais de maneira estimada e da diferenciação entre ligninas de diversas fontes. Diferentes solventes podem influenciar 0 deslocamento de algumas bandas, visto que interagem diferentemente com o soluto, assim, esta é uma dificuldade que a técnica apresenta, particularmente variações de pH em solução aquosa (LIN; DENCE, 1992).

Da mesma maneira que a análise de FTIR no estado sólido, esta análise em solução permite a obtenção de informações como a identificação de grupos funcionais com absorções características. A técnica de FTIR em solução apresenta uma dificuldade analítica, pois exige que a lignina esteja em solução, assim, muitos dos bons solventes utilizados para a solubilização da lignina apresentam absorções acentuadas no espectro, o que dificulta a interpretação das transições vibracionais. É possível, porém, utilizar de subterfúgios para contornar este problema, como, por 
exemplo, realizar uma reação de acetilação da lignina, o que a torna, normalmente, miscível em clorofórmio, que possui somente poucas bandas no espectro de infravermelho, uma em $1210 \mathrm{~cm}^{-1}$ e uma entre 780 e $720 \mathrm{~cm}^{-1}$ (LIN; DENCE, 1992).

Análises de ressonância magnética $\mathrm{NMR}{ }^{13} \mathrm{C}$ e $\mathrm{NMR}{ }^{1} \mathrm{H}$ possibilitam a caracterização estrutural de ligninas, além da diferenciação entre ligninas obtidas por métodos diferentes. Historicamente, os primeiros estudos de NMR ${ }^{1} \mathrm{H}$ de lignina foram realizados com ligninas acetiladas em soluções com clorofórmio, porém nestas condições, não é possível se afirmar com certeza se as reações de acetilação levam a modificação indesejada da lignina, podendo vir a fornecer informações imprecisas. Posteriormente, estudos de NMR ${ }^{1} \mathrm{H}$ foram realizados utilizando ligninas sem serem submetidas a nenhum processo de derivação. A interpretação dos espectros de $\mathrm{NMR}{ }^{13} \mathrm{C}$ é baseada em comparação com informações espectrais de estruturas mais simples, como modelos monoméricos ou diméricos de lignina. A comparação de deslocamentos químicos só pode ser realizada com amostras submetidas ao mesmo procedimento de análise (mesmos solventes, temperatura e etc.) (LIN; DENCE, 1992; HU, 2008).

Análises de GPC possibilitam a avaliação da massa molar e da distribuição de massas molares, parâmetros importantes no estudo da estrutura e propriedades da lignina. Normalmente, a técnica de GPC é bastante empregada em análises do fracionamento de lignina, porém as informações obtidas somente são relacionadas com o volume molar, não permitindo nenhuma conclusão com relação à composição química. Para a determinação das massas molares e polidispersividade das amostras, é necessário a construção de uma curva de calibração com padrões de massa molecular definida e estrutura similar a da amostra, porém, as estruturas mais apropriadas para a construção da curva de calibração, que seriam os modelos dímeros, trímeros, tetrâmeros, etc. de lignina somente estão disponíveis para baixas massas molares, até aproximadamente $800 \mathrm{~g} / \mathrm{mol}$, assim, é necessária a utilização de outros padrões, como o poliestireno (HU, 2008; MARABEZI, 2009). 


\subsubsection{EXTRATIVOS}

Os extrativos são substâncias orgânicas, geralmente de baixa massa molar, de diversas classes, dentre as principais estão compostos aromáticos (fenólicos), terpenos, polissacarídeos de baixo grau de polimerização, ácidos graxos saturados e insaturados, proteínas e flavonoides.

Os estudos relacionados aos extrativos foram feitos, em sua maioria, devido aos problemas que estes compostos podem causar à produção de papel e de polpa celulósica, podendo influenciar as propriedades, por exemplo, do papel. Além disso, alguns destes compostos podem contribuir para a toxicidade dos efluentes da produção da indústria de papel e celulose.

Estes compostos podem ser definidos como qualquer componente que possa ser extraído do biomassa vegetal utilizando-se um ou mais solventes neutros. Assim, dependendo do método de extração as composições e rendimentos das extrações irão variar, por exemplo, extraindo-se com água solubilizar-se-á, principalmente, alguns componentes como açúcares e outros compostos fenólicos, enquanto que com uma extração com hexano solubilizar-se-á compostos apolares, como ácidos graxos e gorduras (BALOGH, 1989; EK et al., 2009; MARABEZI, 2009).

\subsection{PROCESSOS DE DESLIGNIFICACCÃO}

Os processos de deslignificação, como o próprio nome indica, são processos que visam à remoção da lignina, através da solubilização dos fragmentos produzidos pelo rompimento de ligações químicas da protolignina (lignina "in situ"). Os processos de deslignificação são fortemente influenciados pela origem/morfologia das diferentes células e pelas diferentes maneiras de associação entres os componentes dos tecidos vegetais. Esta associação é conhecida por ultra-estrutura (CURVELO, 1992; PASQUINI, 2004).

Existem diversos processos de extração de ligninas, sendo que alguns utilizam substâncias inorgânicas para realizar as cisões das ligações químicas, dentre eles estão os processos industriais mais usados nas indústrias de papel e 
celulose (processo Kraft, sulfito e soda). Existem ainda métodos que utilizam processos físicos, com o auxílio da água, para a quebra de ligações, como o método "steam explosion" (ou lignina liberada por explosão) ou o processo de liberação da lignina através da moagem (MWL). Nos processos físicos de quebra de ligações ainda é necessário realizar uma extração ou com solventes orgânicos ou com solução aquosa de hidróxido de sódio para retirar a lignina que foi liberada.

Outro tipo de processo é o organossolve, o qual utiliza solventes orgânicos que têm o papel de solubilizar fragmentos de lignina. O processo organossolve é especialmente interessante devido possibilidade da recuperação dos solventes. Nos processos que utilizam solvente orgânico ainda é possível utilizar catalizadores (ácidos, ou básicos) e altas pressões (reação utilizando fluido subcrítico e supercrítico) (BALOGH, 1989; CURVELO, 1992; PEREZ, 1996; PASQUINI, 2004).

\subsubsection{PROCESSOS ALCALINOS}

Os processos alcalinos se utilizam de reagentes inorgânicos, principalmente o hidróxido de sódio, para a elevação do pH do meio reacional,. Nestes processos de deslignificação são utilizadas, além das elevadas cargas de reagentes inorgânicos, temperaturas bem acima da temperatura de ebulição da água. A presença de compostos alcalinos, além de atuar no inchamento das fibras de madeira, permitem a ocorrência de reações que facilitam a quebra e a dissolução dos fragmentos de lignina. A fragmentação é facilitada principalmente pela ionização de grupos hidroxila alifáticos e de grupos fenólicos, realizada pelo $\mathrm{NaOH}$, o que os torna nucleófilos mais fortes nas reações subsequentes, além de tornar os fragmentos menores ionizados e, consequentemente, solúveis. Na figura 12 pode-se observar as estruturas de ressonância que estabilizam a formação de íons fenolato. 
Figura 12 - Estruturas de ressonância do íon fenolato.

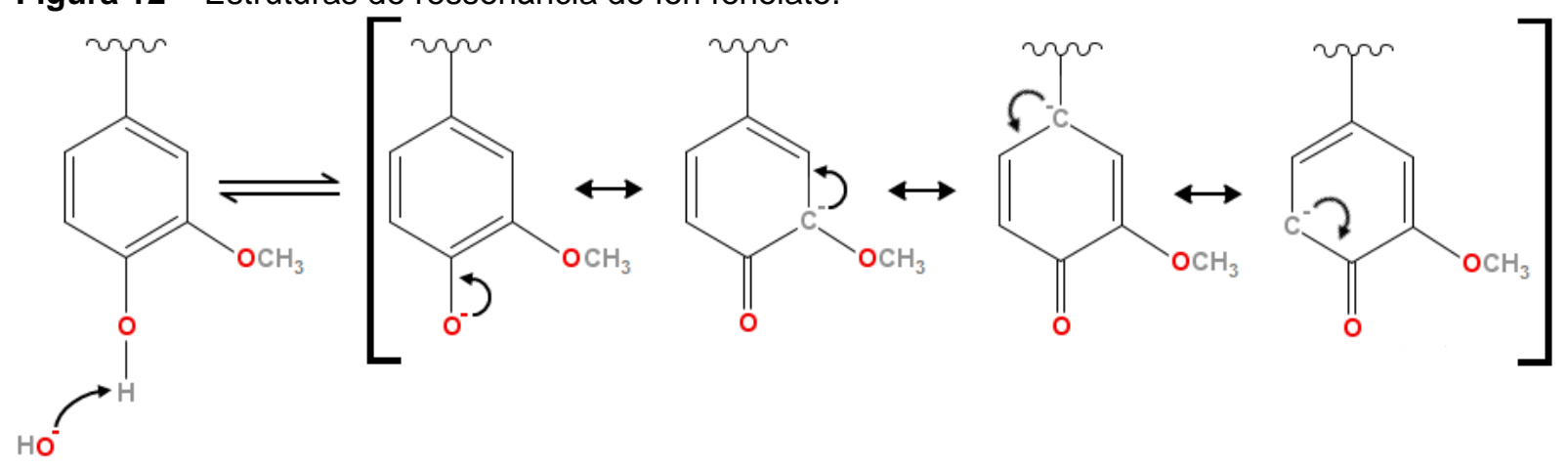

A carga de hidróxido de sódio adicionada a reação é elevada, visto que o consumo de $\mathrm{NaOH}$ também é grande devido à solubilização dos fragmentos fenólicos e da neutralização de extrativos ácidos e de componentes ácidos associados a degradação da fração polissacarídica.

A adição de outros reagentes, inorgânicos ou não, além do $\mathrm{NaOH}$ também tem sido empregada industrialmente. Na polpação Kraft temos a adição de sulfeto de sódio e/ou antraquinona. A adição deste reagentes altera a cinética do processo de deslignificação e preserva a fração celulósica.

Os aditivos mais comuns adicionados às polpações alcalinas são o sulfeto de sódio $\left(\mathrm{Na}_{2} \mathrm{~S}\right)$ e a antraquinona, podendo ser usados isoladamente ou em conjunto. Enquanto o primeiro possui a função de atuar na reação como um forte nucleófilo, visto que de fato na solução aquosa o mesmo está na forma de $\mathrm{NaSH}$, o segundo atua facilitando a dissolução da lignina na solução aquosa, podendo também atuar como fornecedor de elétrons em uma reação redox.

O mecanismo de reação possui um importante intermediário do tipo metileno quinona. Este intermediário é formado pela saída de um substituinte do carbono C- $\alpha$ de um íon fenolato (já com a dissociação do hidrogênio do grupo fenol terminal), como se pode observar na figura 13 no passo I. Esta primeira reação ocorre devido à estabilidade de ambas as estruturas formadas, tanto a estrutura metileno quinona quanto o grupo de saída ( $-\mathrm{RO}$, sendo, nestes casos, $\mathrm{R}$ principalmente igual a grupos arila). 
Figura 13 - Mecanismo de formação do intermediário do tipo metileno quinona e posteriores reações em meio alcalino.

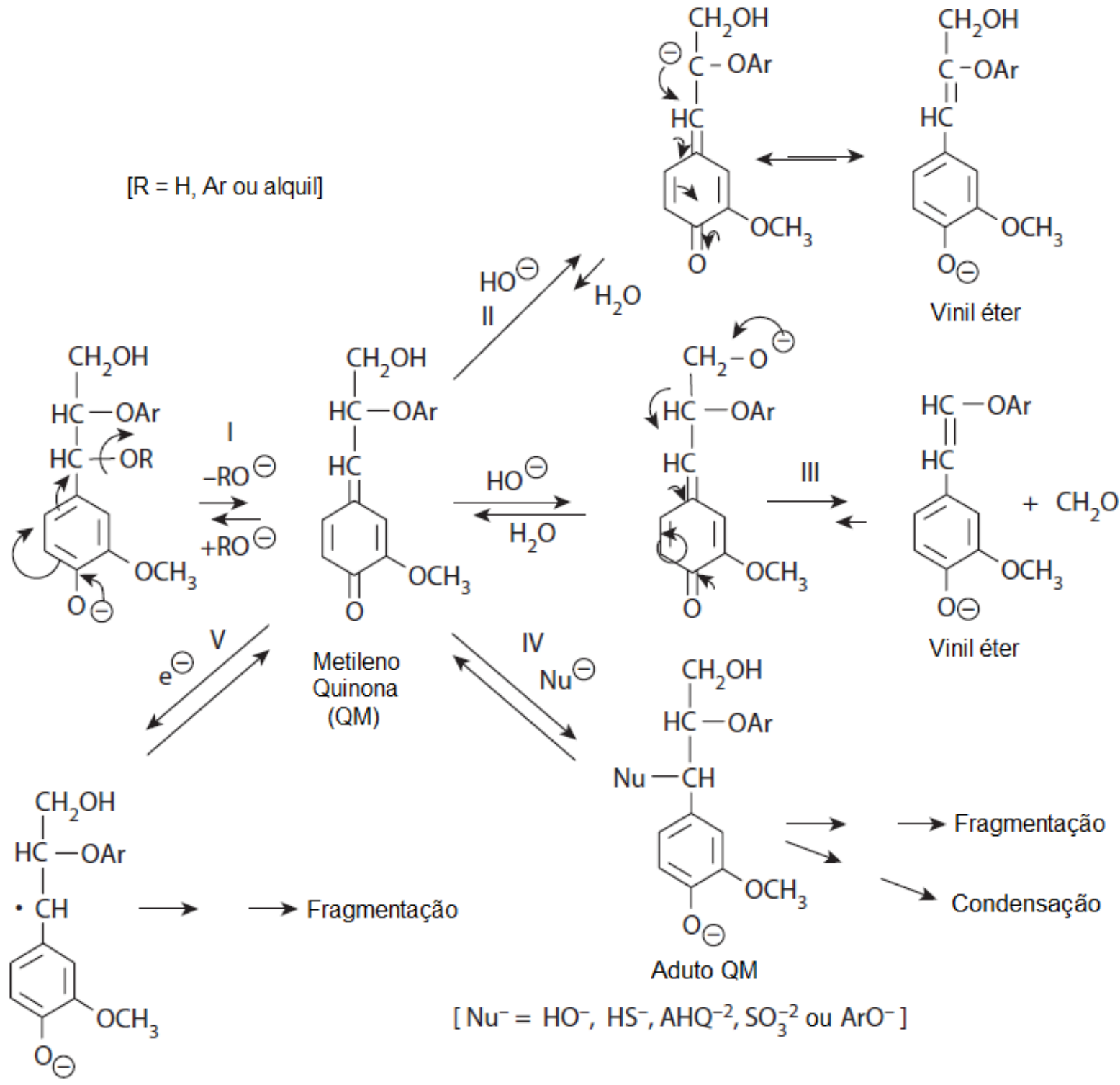

Fonte: HEITNER, C. et al. Lignin and lignans advances in chemistry. Boca Raton, FL: Taylor \& Francis, 2010. 629 p. (Adaptado)

A elevada reatividade da estrutura do tipo metileno quinona permite a rápida conversão deste intermediário aos outros produtos que, por sua vez podem se fragmentar, ou sofrer reações de condensação.

Para polpações Kraft, na qual utiliza-se sulfeto como aditivo a cisão da ligação aril-éter do tipo $\beta-O-4$ ocorre conforme indicado na figura 14 . 
Figura 14 - Mecanismo simplificado de quebra da ligação $\beta-O-4$ em polpações Kraft.

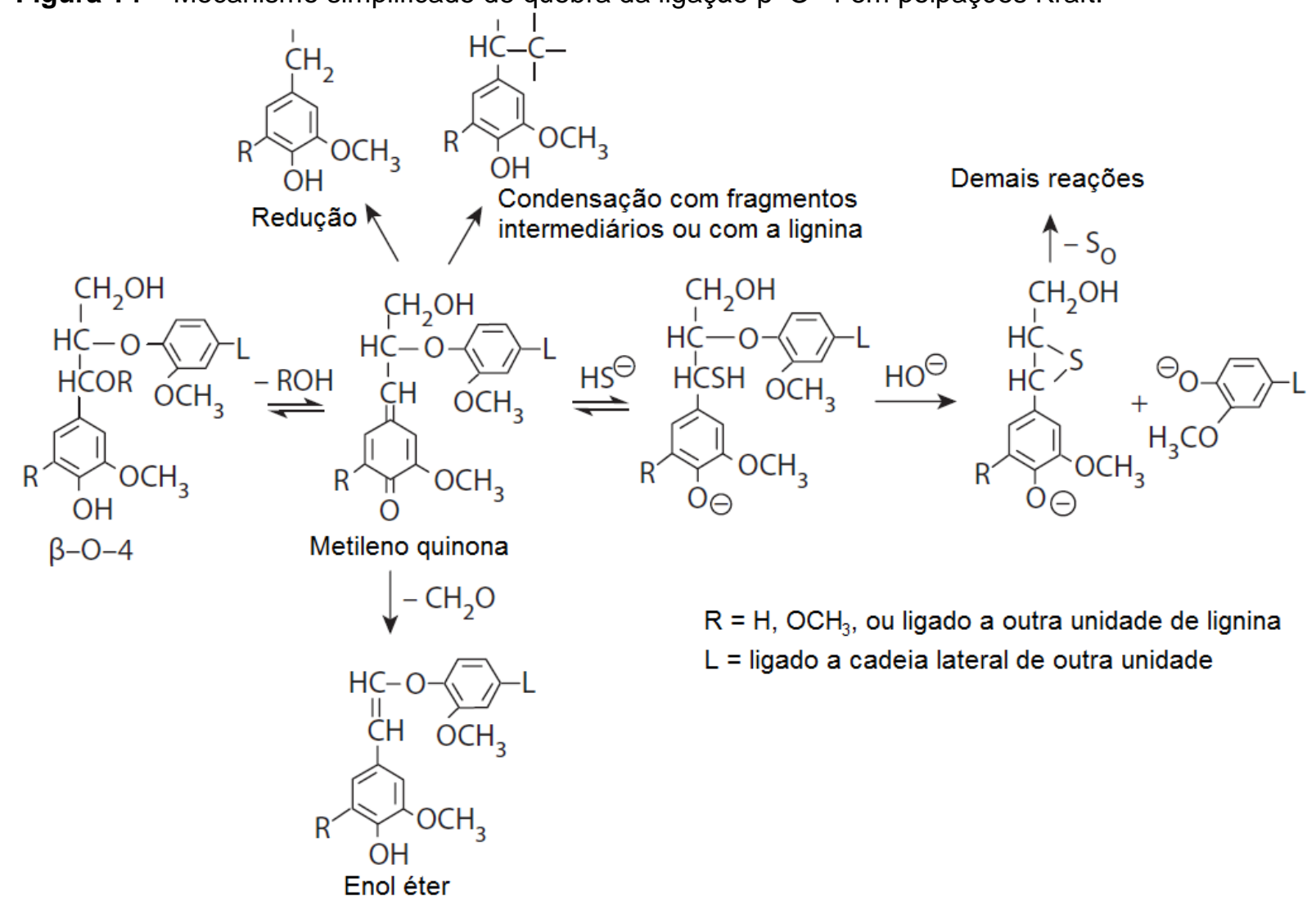

Fonte: HEITNER, C. et al. Lignin and lignans advances in chemistry. Boca Raton, FL: Taylor \& Francis, 2010. 629 p. (Adaptado)

Para as polpações que utilizam antraquinona como aditivo, ocorre um mecanismo reacional diferenciado. A antraquinona ( $A Q$ ) na presença de carboidratos sofre uma reação de oxido-redução levando a formação do intermediário $\mathrm{AHQ}^{-2}$ como se pode observar na figura 15. Após a formação deste intermediário, o mesmo pode atuar na quebra da ligação aril-éter do tipo $\beta-0-4$ como indicado na figura 16 (HEITNER et al., 2010). 
Figura 15 - Reação de óxido-redução da antraquinona na presença de carboidratos.

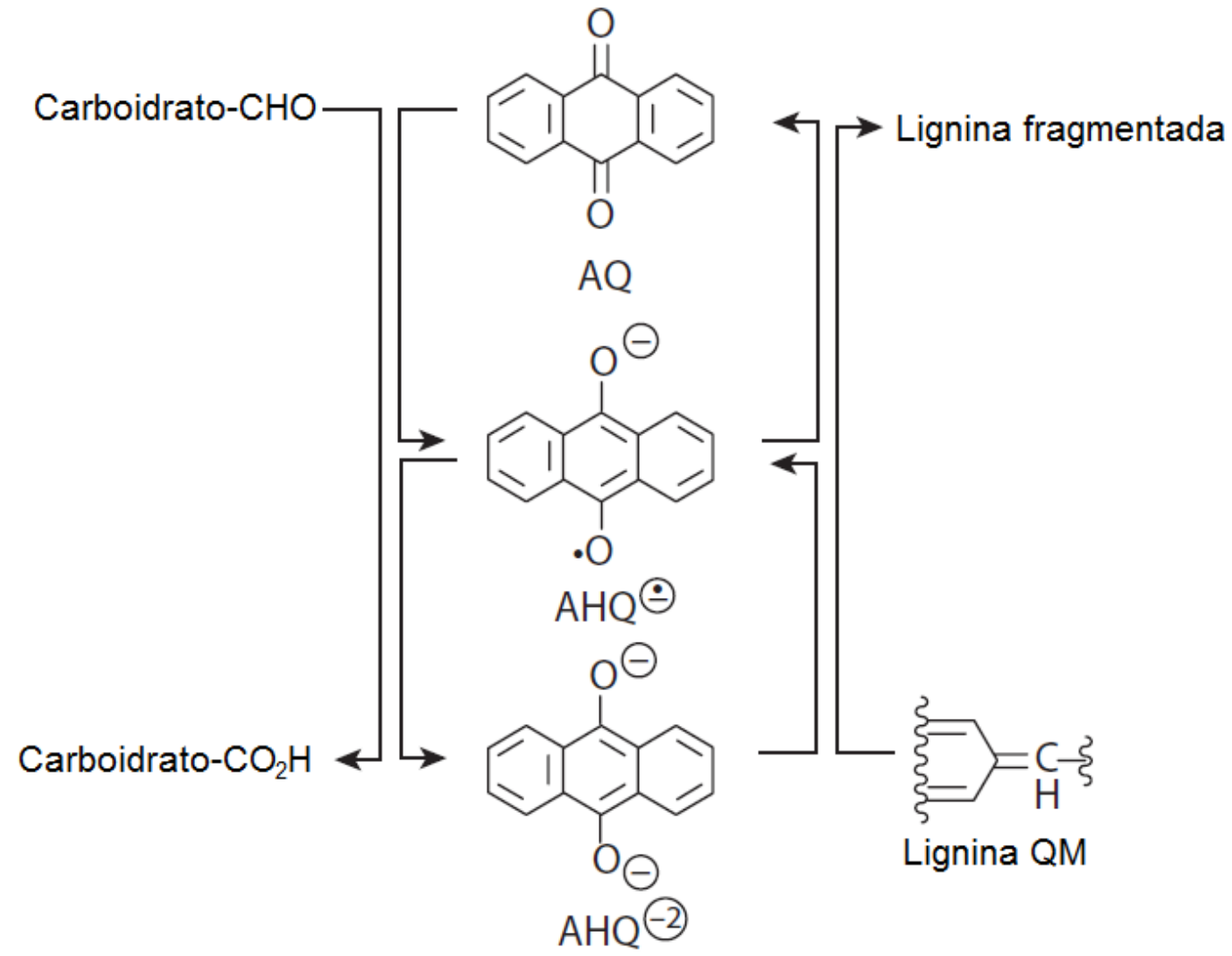

Fonte: HEITNER, C. et al. Lignin and lignans advances in chemistry. Boca Raton, FL: Taylor \& Francis, 2010. 629 p. (Adaptado)

Figura 16 - Mecanismo de quebra da ligação $\beta-\mathrm{O}-4$ em polpações com antraquinona.

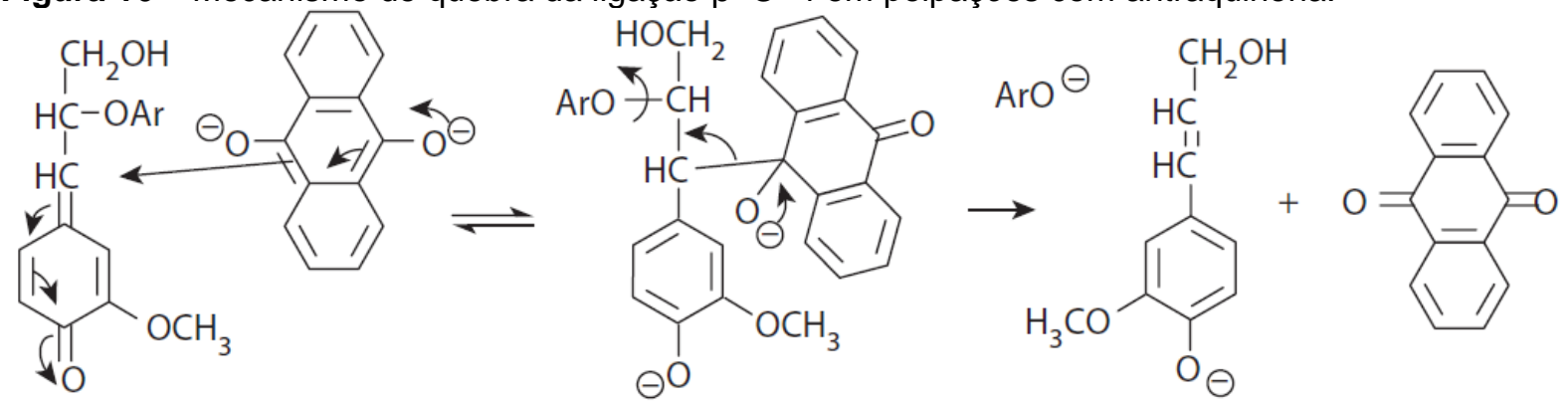

Fonte: HEITNER, C. et al. Lignin and lignans advances in chemistry. Boca Raton, FL: Taylor \& Francis, 2010. $629 \mathrm{p}$.

\subsubsection{PROCESSOS FÍSICOS}

As polpações que se utilizam de pré-tratamentos físicos para a promoção de quebras de ligação na lignina envolvem geralmente a aplicação de forças de cisalhamento, como as que ocorrem durante as operações de moagem intensiva. 
Exemplo deste tipo de tratamento são as ligninas MWL (Milled Wood Lignin - lignina de madeira moída). Na figura 17 pode-se observar uma sugestão de fragmentação da lignina durante o processo MWL.

Figura 17 - Fragmentação da lignina sugerida durante o processo MWL.

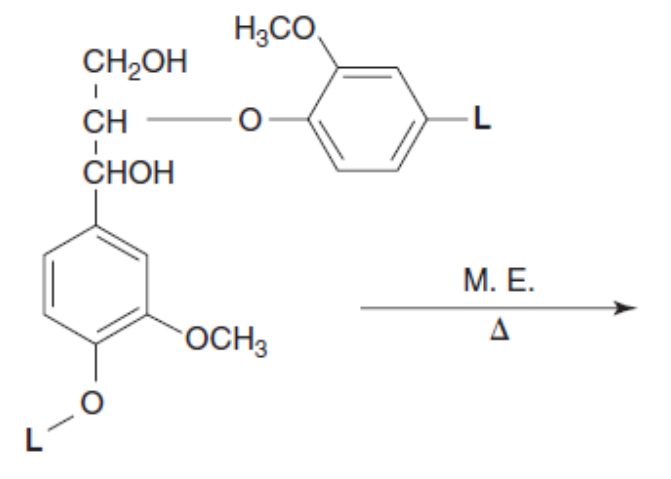

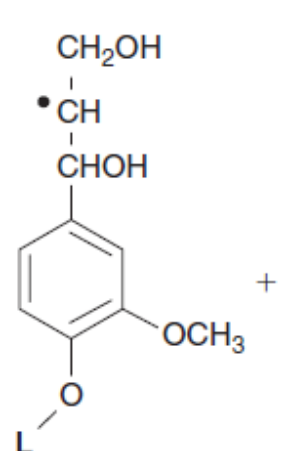

L

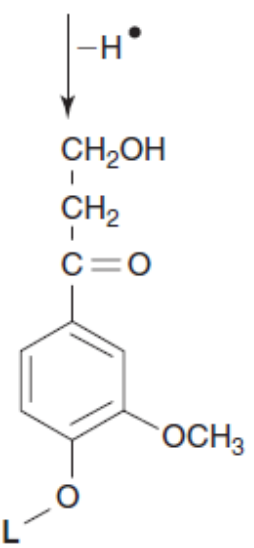<smiles>COc1ccc(I)cc1OC</smiles><smiles>COc1cc(I=CI)ccc1O</smiles>

$\mathrm{OH}$

Fonte: BELGACEM, M. N.; GANDINI, A. Monomers, polymers and composites from renewable resources. Amsterdam: Elsevier, 2008. $552 \mathrm{p}$.

Nos processos físicos para que ocorra o isolamento, propriamente dito, da lignina do material lignocelulósico, é necessário utilizar procedimentos de extração com solventes orgânicos apropriados, normalmente por períodos muito longos, para garantir a dissolução dos fragmentos produzidos.

Devido ao fato de somente ocorrerem quebras de ligação por forças de cisalhamento, acredita-se que as ligninas obtidas por estes possuem estrutura química mais próxima da estrutura "in situ", sendo, desta maneira, muitas vezes utilizada como uma lignina padrão (especialmente a lignina MWL) (BELGACEM; GANDINI, 2008). 


\subsubsection{PROCESSOS EM MEIO ÁCIDO}

Os processos organossolve normalmente ocorrem ou em $\mathrm{pH}$ neutro ou em $\mathrm{pH}$ ácido. Para ambos os casos, o mecanismo de reação é similar, sendo que a degradação ocorre principalmente através da protonação de hidroxilas na cadeia lateral ou do oxigênio da ligação éter, ou aril-éter, gerando grupos de saída estáveis (água ou álcoois) e um carbocátion, que pode estar estabilizado pela delocalização da carga por ressonância entre carbonos com duplas ligações ou por grupos doadores de densidade eletrônica. Nas figuras 18, 19, 20 e 21 pode-se observar os mecanismos de formação de carbocátions na cadeia lateral de uma unidade monomérica de lignina, os sítios de alta $\left(\delta^{-}\right)$e baixa $\left(\delta^{+}\right)$densidade eletrônica em meio ácido de unidades arilpropano e arilpropeno, o mecanismo de solvólise da ligação aril-éter $\alpha-\mathrm{O}-4$ e o mecanismo de solvólise da ligação aril-éter $\beta-\mathrm{O}-4$, respectivamente.

Figura 18 - Mecanismo de formação de 3 carbocátions na cadeia lateral.

$$
\begin{aligned}
& \mathrm{R}-\mathrm{CH}=\mathrm{CH}-\mathrm{CH}_{2}-\mathrm{OH}+\mathrm{H}^{+} \longrightarrow \mathrm{R}-\mathrm{CH}=\mathrm{CH}-\mathrm{CH}_{2}-\stackrel{+}{\mathrm{O}} \mathrm{H}_{2} \longrightarrow \mathrm{H}_{2} \mathrm{O}+\left[\mathrm{R}-\mathrm{CH}=\mathrm{CH}-\stackrel{+}{\mathrm{C}} \mathrm{H}_{2} \longleftrightarrow \mathrm{R}-\stackrel{+}{\mathrm{C}} \mathrm{H}-\mathrm{CH}=\mathrm{CH}_{2}\right]
\end{aligned}
$$

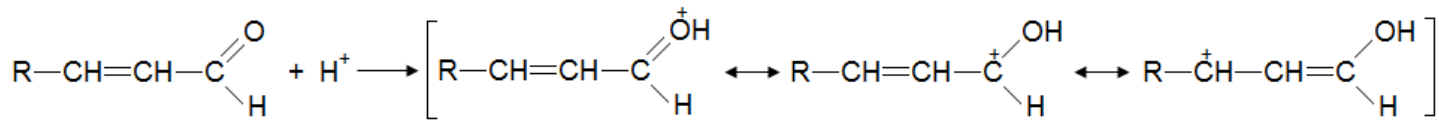

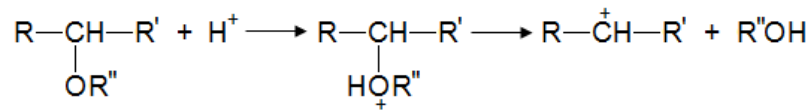

Fonte: FENGEL, D.; WEGENER, G. Wood : chemistry, ultrastructure, reactions. Berlin: W. de Gruyter, 1984. 613p. 
Figura 19 - Sítios de alta $\left(\delta^{-}\right)$e baixa $\left(\delta^{+}\right)$densidade eletrônica em meio ácido de unidades arilpropano (a) e arilpropeno (b).

a)

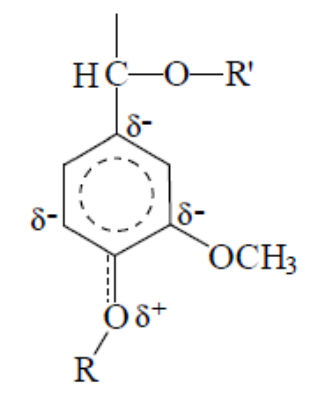

b)<smiles>[R]OC[C-]=C1[C+]C=C([O+][R])C(OC)=[C-]1</smiles>
$\mathrm{R}=\mathrm{H}$, Alquila
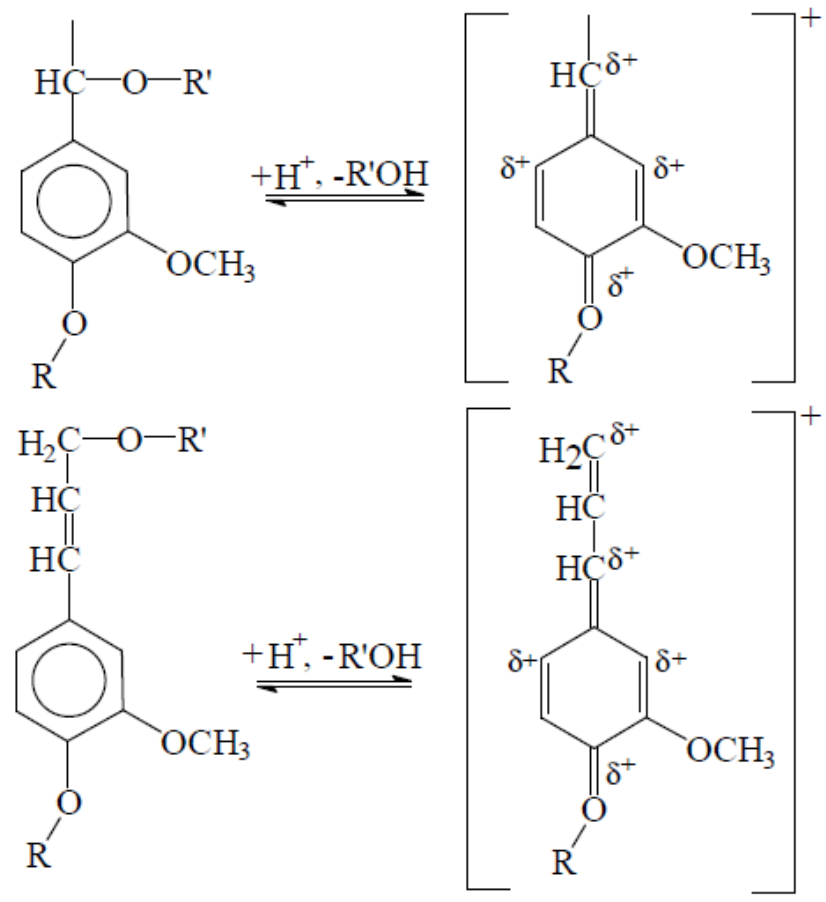

Fonte: FENGEL, D.; WEGENER, G. Wood : chemistry, ultrastructure, reactions. Berlin: W. de Gruyter, 1984. 613p.

Figura 20 - Mecanismo de solvólise da ligação a-O-4.

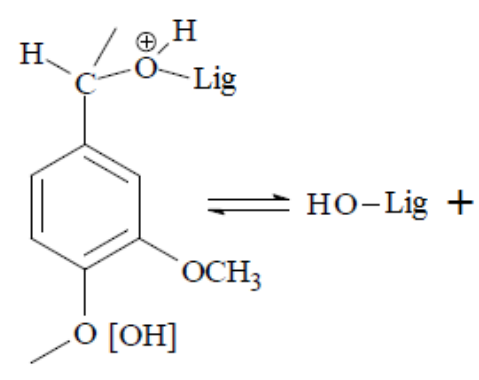<smiles>C[CH]c1ccc(OC)c(O)c1</smiles><smiles>C/C=C1/[C+]C(OC)=C(OO)C=C1</smiles><smiles>CC=c1ccc(=CC)c(OC)c1</smiles><smiles>[C+]1=CC=C1</smiles><smiles>CCCCCOC(C)c1ccc(OC)c(OC)c1</smiles>

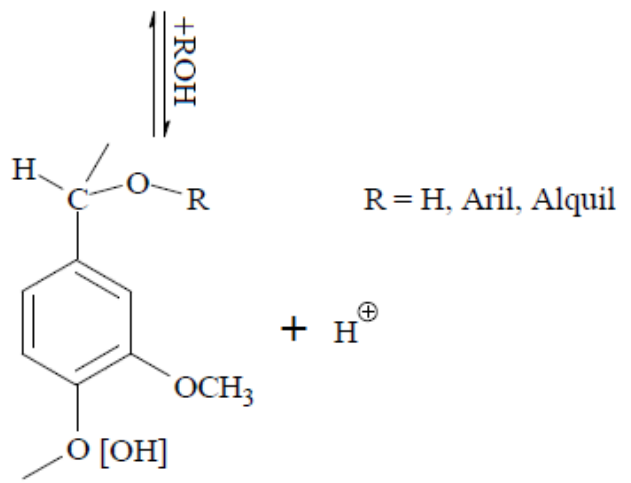

Fonte: FENGEL, D.; WEGENER, G. Wood : chemistry, ultrastructure, reactions. Berlin: W. de Gruyter, 1984. 613p. (Adaptado). 
Figura 21 - Um dos possíveis mecanismos de solvólise da ligação $\beta-0-4$.
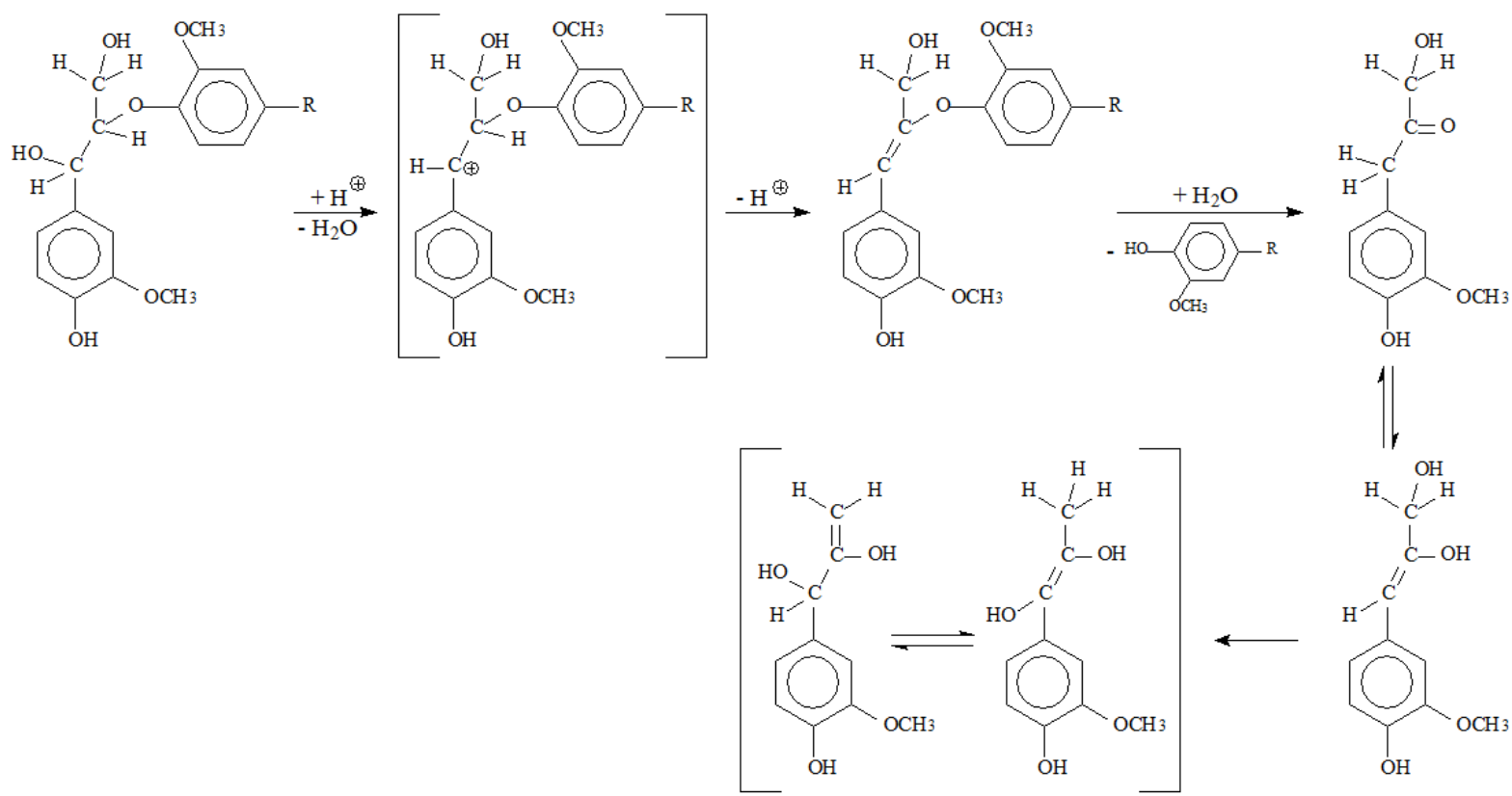

Fonte: FENGEL, D.; WEGENER, G. Wood : chemistry, ultrastructure, reactions. Berlin: W. de Gruyter, 1984.613p. (Adaptado).

Nas figuras 20 e 21, pode-se observar que na solvólise dependendo do solvente orgânico no qual a reação é realizada, outras moléculas além da água podem atuar como nucleófilos, dependendo da capacidade de doação de elétrons das mesmas.

Nos processos de deslignificação em meio ácido, alguns fatores, como a concentração elevada de ácido ou uma dissolução muito elevada de fragmentos de lignina, podem levar a ocorrência de reações paralelas de condensação envolvendo os carbocátions e carbonos do anel aromático, como pode-se observar na figura 22. Nestes casos, ocorre a competição entre as reações de condensação e as reações de degradação, tornando a deslignificação efetiva mais difícil de ocorrer (FENGEL; WEGENER, 1984; AZIZ; SARKANEN, 1989; PASQUINI, 2004). 
Figura 22 - Reações de condensação de ligninas em meio ácido.

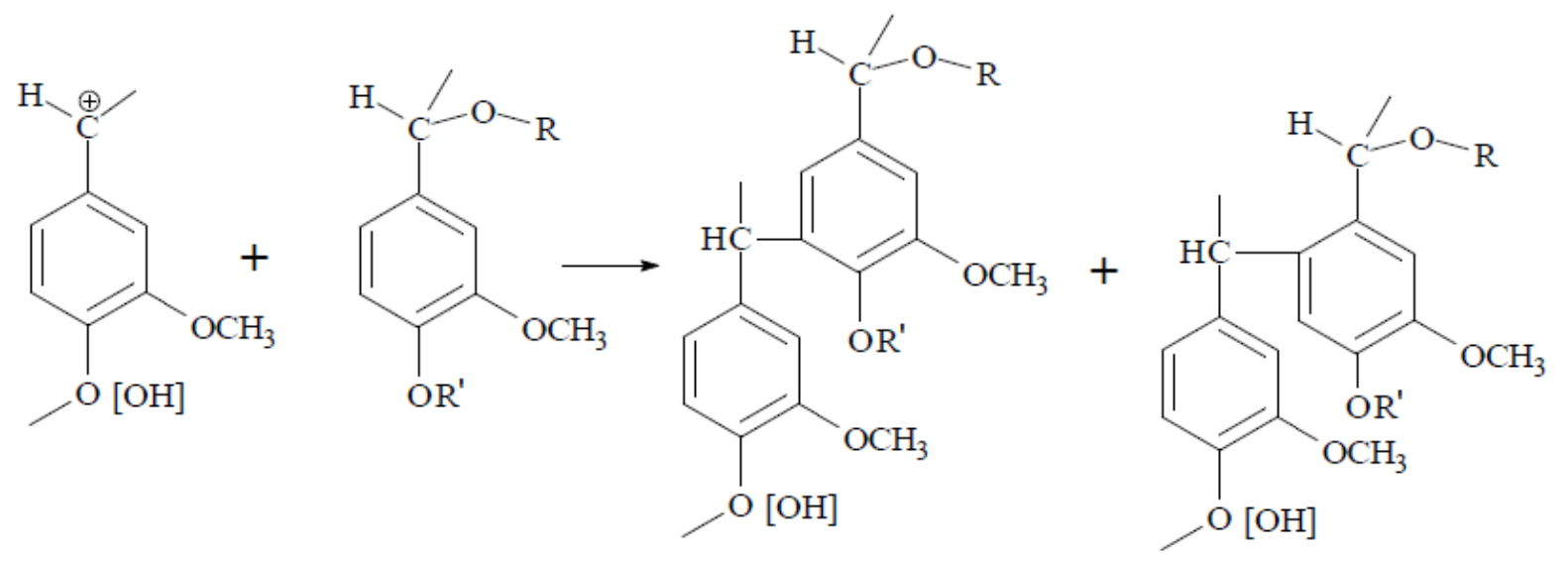

Fonte: AZIZ, S.; SARKANEN, K. Organosolv Pulping - A Review. Tappi Journal, v. 72, n. 3, p. 169175, 1989. (Adaptado).

Em polpações organossolve realizadas sem adição de ácidos a hidrólise de grupos acetila presentes em hemiceluloses leva à produção de ácido acético que atua como catalisador (mecanismos de auto-hidrólise) (CARVALHEIRO et al., 2008; NOVO et al., 2011).

\subsection{PARÂMETROS DE SOLUBILIDADE}

Do ponto de vista físico-químico, as teorias de parâmetros de solubilidade podem fornecer subsídios importantes para a compreensão do fenômeno da solubilidade e para a escolha da melhor composição de solventes para uma efetiva extração de ligninas em processos de deslignificação organossolve.

Dentre as propostas que apresentam parâmetros de solubilidade, duas teorias se destacam: a teoria de Hildebrand e teoria de Hansen. O primeiro autor propõe apenas um parâmetro e o segundo, três parâmetros de solubilidade.

Para que ocorra a solubilização de um soluto, é necessário que as interações intermoleculares entre as moléculas do solvente $(A-A)$ e do soluto $(B-B)$ sejam da mesma ordem de grandeza. Assim é possível que as interações $A-A$ e $B-B$ sejam quebradas para a formação de interações do tipo A-B. Termodinamicamente, para a ocorrência de um processo espontâneo de solubilização entre dois componentes diferentes, é necessário que a variação da energia livre de mistura $\left(\Delta G_{M}\right)$ seja nula ou negativa. A variação de $\Delta G_{M}$ ocorre segundo a equação 1 . 


$$
\Delta G_{M}=\Delta H_{M}-\mathrm{T} \cdot \Delta \mathrm{S}_{M} \quad \text { Equação } 1
$$

Onde $\Delta H_{M}$ corresponde à entalpia de mistura (ou calor de mistura) e $\Delta S_{M}$ à entropia de mistura. Considerando o caso no qual as forças intermoleculares sejam idênticas, a solução formada é uma solução ideal e a mistura ocorre com $\Delta H_{M}$ igual a zero (VERNERET, 1984; BALOGH, 1989; HANSEN, 2007).

\subsubsection{PARÂMETRO DE SOLUBILIDADE DE HILDEBRAND}

Para uma mistura isotérmica entre " $i$ " líquidos miscíveis (caso onde as interações intermoleculares são da mesma ordem de grandeza), $\Delta U_{i}$ é a energia interna do sistema, e corresponde a energia total relacionada à interação entre as partículas. Assim, para que ocorra o rompimento das mesmas seria necessário fornecer $\Delta U_{i}$ para o sistema e ocorreria a transição entre a fase líquida e a fase gasosa. Da mesma maneira é possível se determinar a densidade de energia de coesão, dividindo-se $\Delta U_{i}$ por $\bar{V}_{i}$ (volume molar para uma molécula " $i$ " qualquer).

Hildebrand determinou o parâmetro de solubilidade $\delta$ para o componente $i$ como sendo a raiz quadrada da densidade de energia de coesão, como indicado na equação 2.

$$
\delta_{i}=\sqrt{\frac{\Delta U_{i}}{\bar{V}_{i}}}
$$

Equação 2

Para o caso da formação de vapor a baixa pressão, o mesmo pode ser considerado um vapor ideal, assim $\Delta U_{i}$ pode ser escrito como sendo igual a $\Delta_{v} H_{i}-R T$, no qual $\Delta_{v} H_{i}$ é a entalpia de vaporização para o componente " $i$ ", $R$ a constante universal dos gases e $T$ a temperatura. Assim a equação 2 pode ser escrita como sendo (equação 3):

$$
\delta_{i}=\sqrt{\frac{\Delta_{v} H_{i}-R T}{\bar{V}_{i}}}
$$


Desta maneira, considerando " $\delta_{i}$ " para cada componente puro, teremos $\delta_{A} \mathrm{e}$ $\delta_{B}$, para dois componentes que se deseja misturar Se os mesmos forem próximos, o que indica energias de interação próximas, as duas substâncias se misturam (para casos que tratam de interações intermoleculares de um mesmo tipo).

Observa-se pela equação 3 que a unidade de $\delta$ corresponde a $\sqrt{J / \mathrm{cm}^{3}}$ ou $\sqrt{\mathrm{cal} / \mathrm{cm}^{3}}$, ou seja, a raiz quadrada de uma unidade de energia, ou força, por uma unidade de volume, o que nada mais é do que a raiz quadrada de uma unidade de pressão. No sistema internacional, utiliza-se como padrão para parâmetros de solubilidade a unidade $\mathrm{MPa}^{1 / 2}$ (que é numericamente idêntico a $\sqrt{\mathrm{MJ} / \mathrm{m}^{3}}$ ), porém a unidade $\mathrm{cal}^{1 / 2} \mathrm{~cm}^{-3 / 2}$ também é amplamente utilizada. A conversão entre $\mathrm{cal}^{1 / 2} \mathrm{~cm}^{-3 / 2}$ e $\mathrm{MPa}^{1 / 2}$ ocorre pelo produto do segundo por 2,0455 para cada unidade do primeiro.

Para uma solução composta de diversos componentes, o parâmetro de solubilidade de Hildebrand correspondente é descrito pela equação 4 , no qual $\phi_{i}$ é a fração volumétrica do componente " $i$ " na solução, e $\delta_{i}$ o parâmetro de solubilidade do componente " $i$ " puro.

$$
\delta_{\text {solução }}=\frac{\sum_{i} \phi_{i} \delta_{i}}{\sum_{i} \phi_{i}} \quad \text { Equação } 4
$$

Considerando, agora o componente " $C$ " como sendo um soluto, e $\delta_{C}$ como sendo seu parâmetro de solubilidade. Se $\delta_{A}<\delta_{C}<\delta_{B}$, sendo " $A$ " e " $B$ " dois líquidos que não dissolvem " $C$ ", então uma mistura específica entre ambos solubilizará 0 soluto completamente.

Para uma solução binária, Hildebrand e Scott determinaram que $\Delta H_{M}$ corresponderia ao produto entre as frações volumétricas dos componentes 1 e 2 ( $\phi_{1}$ e $\phi_{2}$, respectivamente), o volume de mistura $\left(V_{M}\right)$ e o quadrado da diferença entre os parâmetros de solubilidade dos componentes $\begin{array}{llllllllll}\delta_{1} & \text { e } & \delta_{2} \text {, }\end{array}$ respectivamente), como demonstrado na equação 5 .

$$
\Delta H_{M}=\phi_{1} \phi_{2} V_{M}\left(\delta_{1}-\delta_{2}\right)^{2} \quad \text { Equação } 5
$$

A validade da equação 5 ocorre somente nos casos em que a mistura tenha calores de mistura positivos, visto que o termo da direita da equação será sempre positivo, assim, um termo que seria mais apropriado para a descrição seria um relacionado com a energia de Gibbs, que também se comporta desta maneira, para processos espontâneos (HILDEBRAND, 1916; HOY, 1970; BARTON, 1975; 
BARTON, 1983; VERNERET, 1984; BALOGH, 1989; UTRACKI; SIMHA, 2004; HANSEN, 2007; CRC, 2011).

\subsubsection{PARÂMETROS DE SOLUBILIDADE DE HANSEN}

O parâmetro de solubilidade de Hildebrand pode não expressar o que ocorre em certos casos como, por exemplo, o etanol e o nitrometano, o primeiro possui um $\delta$ igual a 26,1 $\mathrm{MPa}^{1 / 2}$ e o segundo um $\delta$ igual a 25,1 $\mathrm{MPa}^{1 / 2}$. Assim, por esta teoria, ambos teriam propriedades semelhantes, visto que possuem um parâmetro de solubilidade numericamente muito próximo, porém isto não ocorre. O etanol é miscível em água, enquanto que o nitrometano não. De fato, observou-se que misturas entre nitroparafinas e álcoois podem formar misturas sinérgicas (na qual cada solvente atua para a solubilização de uma forma diferente, porém complementares entre si) de dois não solventes individualmente solubilizando em conjunto um polímero. Assim, verificou-se a necessidade da revisão da teoria desenvolvida por Hildebrand e Scott, visto que a mesma desconsidera o tipo de interação específica que cada solvente pode realizar.

Existem quatro tipos de interações intermoleculares que influenciam as forças coesivas: As forças dispersivas (forças de London, ou dipolo induzido-dipolo induzido), forças entre dipolos permanentes, forças entre dipolo-dipolo induzido e as ligações de hidrogênio. De modo geral, as interações do tipo dipolo-dipolo e dipolodipolo induzido são similares e podem ser chamadas, simplesmente por interações polares. Assim em uma substância pura na qual só existissem interações dispersivas o parâmetro de solubilidade pode ser escrito como sendo (equação 6):

$$
\delta_{d}=\sqrt{\frac{\Delta U_{d}}{\bar{V}}}
$$

Equação 6

Similarmente o mesmo poderia ocorrer para substâncias com interações polares ou ligações de hidrogênio, as equações 7 e 8 indicam os parâmetros de solubilidade para estes casos, respectivamente.

$$
\delta_{p}=\sqrt{\frac{\Delta U_{p}}{\bar{V}}}
$$




$$
\delta_{h}=\sqrt{\frac{\Delta U_{h}}{\bar{V}}} \quad \text { Equação } 8
$$

Assim, no caso de uma substância que possua os três tipos de interações intermoleculares, seria necessário somar as contribuições individuais, como demonstrado na equação 9 .

$$
\delta=\sqrt{\frac{\Delta U_{\text {Total }}}{\bar{V}}}=\sqrt{\frac{\Delta U_{d}+\Delta U_{p}+\Delta U_{h}}{\bar{V}}}=\sqrt{\delta_{d}^{2}+\delta_{p}^{2}+\delta_{h}^{2}} \quad \text { Equação 9 }
$$

Desta maneira, para Hansen, cada solvente pode ser descrito como sendo um ponto (representado pela soma de três vetores) em um espaço tridimensional, no qual cada dimensão representa um tipo de interação intermolecular.

Da mesma maneira que para os parâmetros de solubilidade de Hildebrand, uma solução contendo mais de um solvente possui parâmetros de solubilidade de Hansen diferentes dos parâmetros para os componentes puros, podendo-se aplicar, para cada parâmetro (parâmetro para interações dispersivas, polares e ligações de hidrogênio), a equação 4 descrita anteriormente (HANSEN, 1967a; b; HANSEN; SKAARUP, 1967; BARTON, 1975; KIRK; OTHMER, 2004; HANSEN, 2007).

\subsubsection{CÁLCULO DOS PARÂMETROS DE SOLUBILIDADE DE HANSEN}

Atualmente, um grande número de solventes possui os parâmetros de solubilidade já calculados, podendo ser achados valores tabelados na literatura. $\mathrm{O}$ cálculo dos parâmetros de solubilidade pode ser realizado de diversas maneiras (HANSEN, 2007).

As primeiras tentativas de obtenção dos valores para os parâmetros de solubilidade parciais foram realizadas experimentalmente, a partir da comparação entre grupos e suas contribuições, as quais foram confirmadas posteriormente por testes de solubilidade. Assim, determina-se primeiramente a contribuição de $\delta_{d}$. Por exemplo, para os hidrocarbonetos alifáticos saturados pode-se considerar que somente ocorram forças coesivas dispersivas, assim a energia de vaporização pode ser assumida como sendo igual à energia de coesão dispersiva, " $U_{d}$ ". Desta maneira, determina-se a contribuição das forças dispersivas para estruturas 
homomórfas, ou para as partes hidrocarbônicas de algumas moléculas de líquidos. A partir de gráficos de energia coesiva, ou densidade de energia de coesão, em função do volume molar e da temperatura reduzida $\left(T_{r}=T / T_{c}\right.$, assume-se $T$ como sendo 298,15K), para alcanos alifáticos, cicloalcanos e hidrocarbonetos aromáticos, pode-se obter a contribuição das estruturas apolares para uma dada molécula. Algumas correções a respeito do tamanho dos átomos e estruturas envolvidas devem ser utilizadas (HANSEN, 2007).

Para as interações polares, o momento de dipolo $(D M)$ é o parâmetro primário para o cálculo de $\delta_{p}$. Assim, utilizando a equação 10 desenvolvida por Hansen e Beerbower (KIRK; OTHMER, 2004) pode-se obter uma boa estimativa do parâmetro $\delta_{p}$.

$$
\delta_{p}=37,4(D M) / \bar{V}^{1 / 2} \quad \text { Equação } 10
$$

Para estruturas com momento de dipolo igual a zero devido à simetria, como o tetracloreto de carbono, não necessariamente o parâmetro para interações polares será igual a zero, podendo variar dependendo do meio ao qual está submetido. Um exemplo disto é o dissulfeto de carbono, que em fase gasosa possui medidas de momento de dipolo igual a zero, mas possui um valor de momento de dipolo igual a 0,08 em hexano, 0,49 em clorobenzeno e 1,21 em nitrobenzeno (HANSEN, 2007).

Quando não existe nenhum dado de momento de dipolo disponível, utiliza-se a similaridade entre compostos, tabelas de valores para a contribuição de grupos, a subtração de contribuições de energia dispersiva e de ligações de hidrogênio da energia coesiva, ou a utilização de dados experimentais para a obtenção de uma estimativa do parâmetro de solubilidade para interações polares (HANSEN, 2007).

Nos primeiros trabalhos desenvolvidos com relação aos parâmetros de solubilidade tridimensionais, a obtenção do parâmetro para ligações de hidrogênio, $\delta_{h}$, era realizada pela subtração das energias dispersivas e polares da energia de vaporização total, porém com o desenvolvimento das técnicas de determinação através da contribuição de grupos, principalmente desenvolvidas por Panayiotou, este parâmetro passou a ser determinado teoricamente, com certa confiança (HANSEN, 2007). 
1.4.2.2 PARÂMETROS DE SOLUBILIDADE DE HANSEN PARA POLÍMEROS.

Para polímeros ou moléculas de massa molar elevada, muitas vezes a solubilidade não é um parâmetro obtido diretamente, assim, para os mesmos podese calcular em vez de um ponto no espaço em um diagrama dos parâmetros de solubilidade, determina-se um volume neste espaço tridimensional. Assim, para que ocorra a solubilização desta molécula o ponto representante do parâmetro de solubilidade do solvente deve estar inserido no volume correspondente ao parâmetro de solubilidade do soluto.

Experimentalmente os parâmetros de solubilidade de um polímero, por exemplo, podem ser encontrados realizando diversos testes de solubilidade deste polímero em solventes com parâmetros de Hansen conhecidos. Os pontos dos solventes são colocados em um gráfico e delimita-se o volume contendo somente os solventes nos quais a substância foi solubilizada. Hansen propõe que o volume representante do parâmetro de solubilidade de um soluto deva ser descrito como sendo uma esfera de raio $R_{0}$, o menor possível, na qual exista o maior número de solventes que solubilizem o soluto e o menor número de solventes que não o solubilizem. O parâmetro de solubilidade do sólido pode ser descrito como sendo 0 centro desta esfera. A figura 23 apresenta um exemplo para o parâmetro de solubilidade de Hansen para lignina de madeiras. 
Figura 23 - Representação do parâmetro de solubilidade de HANSEN para a lignina de madeira.

Hansen Solubility Parameters

$\delta \mathbf{D} \quad \delta \mathbf{P} \quad \delta \mathrm{H} \quad \mathbf{R}_{0}$

$\begin{array}{llll}\text { Lignin } \quad 21.9 & 14.1 & 16.9 & 13.7\end{array}$

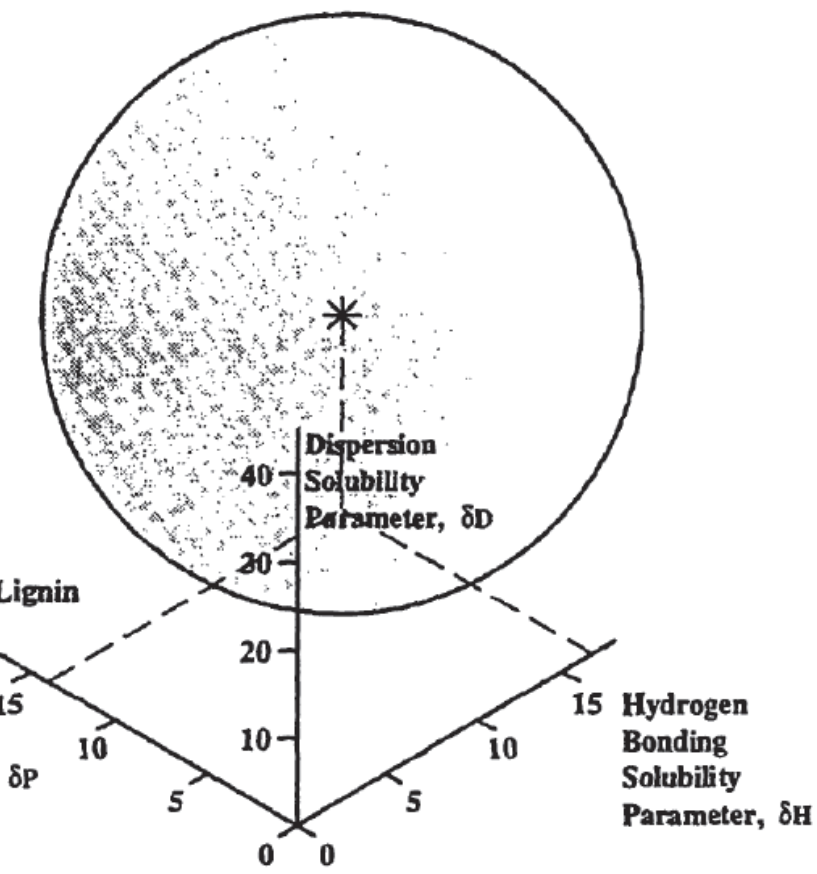

Fonte: HANSEN, C. M.; BJÖRKMAN, A. The Ultrastructure of Wood from a Solubility Parameter point of view. Holzforschung, v. 52, p.335-344, 1998.

Desta maneira, para um dado polímero quanto mais próximo ao centro da esfera estiver um solvente maior será a sua capacidade de solubilização do polímero. Assim, é importante se definir a distância $R_{a}$ entre um solvente e o parâmetro de solubilidade do polímero, a qual é definida geometricamente pela equação 11.

$$
R_{a}=\sqrt{4 \times\left(\delta_{d}^{p o l}-\delta_{d}^{\text {solv }}\right)^{2}+\left(\delta_{p}^{\text {pol }}-\delta_{p}^{\text {solv }}\right)^{2}+\left(\delta_{h}^{\text {pol }}-\delta_{h}^{\text {solv }}\right)^{2}} \quad \text { Equação } 11
$$

Observa-se na equação 12 a presença do índice "4" multiplicando o quadrado da diferença entre os parâmetros de solubilidade de interações dispersivas. Isto ocorre porque se observou empiricamente que ao dobrar a escala para o parâmetro de solubilidade para as interações dispersivas, regiões esféricas, ao invés de elipsoidais, de solubilidade são verificadas. Logo, pode-se verificar que o parâmetro de solubilidade relacionado às interações dispersivas possui uma menor variação numérica, comparado aos outros dois parâmetros de solubilidade.

Desta maneira, definiu-se um parâmetro que relacionasse a capacidade de solubilização, ou simplesmente a afinidade, de cada solvente com relação a um 
polímero. Este parâmetro foi chamado de RED (relative energy diference - diferença de energia relativa) e foi definido como sendo a razão entre a distância $R_{a}$ de um solvente e o raio $R_{0}$ da esfera do polímero, como pode-se verificar na equação 12 .

$$
R E D=\frac{R_{a}}{R_{0}^{\text {pol }}} \quad \text { Equação } 12
$$

Se $R E D$ for igual a "0", isto indica que não existem diferenças energéticas entre o solvente e o polímero, isto é, as interações em ambos são idênticas e a afinidade entre ambos é máxima, ou seja, a distância entre o solvente e o polímero é nula. Se RED for menor do que "1,0" a afinidade entre o solvente e o polímero é elevada. Se $R E D$ for maior do que "1,0" a afinidade entre o solvente e o polímero é pequena e com o crescimento do valor de RED diminui progressivamente a afinidade entre os dois. A condição limite de solubilização, ou a condição de fronteira, ocorre quando o valor de RED é igual ou muito próximo a "1,0" (HANSEN, 1967a; b; HANSEN; SKAARUP, 1967; BARTON, 1975; HANSEN; BJORKMAN, 1998; KIRK; OTHMER, 2004; HANSEN, 2007).

\subsubsection{VARIACÃO DOS PARÂMETROS DE HANSEN COM A TEMPERATURA}

Em diversos casos a solubilidade de uma substância varia com a variação da temperatura, resultando em solubilidade (ou não solubilidade) somente a altas temperaturas. Este é um indicativo claro de que ocorre uma variação dos parâmetros de solubilidade com a temperatura. Poucas tentativas de obtenção dos parâmetros de solubilidade em temperaturas diferentes de $25^{\circ} \mathrm{C}$ foram tentadas, porém uma estimativa pode ser usada para esta determinação. Considera-se para isso que todos os solventes possuem uma mesma dependência com a temperatura, o que se sabe, não é exatamente o que ocorre na realidade. Dentre os três parâmetros de solubilidade, o que é mais influenciado pela elevação da temperatura é o correspondente às ligações de hidrogênio, para este, a energia fornecida pelo aumento da temperatura atua na redução da intensidade (ou mesmo o rompimento) 
das ligações de hidrogênio, resultando em uma diminuição mais rápida do parâmetro $\delta_{h}$ do que de $\delta_{d}$ e $\delta_{p}$ (HANSEN, 2007).

A elevação da temperatura atua nos parâmetros $\delta_{d}$ e $\delta_{p}$ principalmente na variação do volume dos mesmos, já que o momento de dipolo e as forças dispersivas não são consideravelmente variáveis com a temperatura, o que atua na variação da energia coesiva total. Desta maneira, as variações dos três parâmetros de solubilidade com a temperatura podem ser calculadas pelas equações $13,14 \mathrm{e}$ 15 , nas quais $\alpha$ corresponde ao coeficiente de expansão termica (HANSEN, 2007).

$$
\begin{array}{cc}
\frac{d \delta_{D}}{d T}=-1,25 \alpha \delta_{D} & \text { Equação 13 } \\
\frac{d \delta_{P}}{d T}=-0,5 \alpha \delta_{P} & \text { Equação 14 } \\
\frac{d \delta_{H}}{d T}=-\delta_{H}\left(1,22 \times 10^{-3}+0,5 \alpha\right) & \text { Equação 15 }
\end{array}
$$

De modo geral, a elevação da temperatura resulta em aumentos no raio das esferas de solubilidade dos polímeros, e na diminuição dos valores de $\delta_{d}$, $\delta_{p}$ e $\delta_{h}$ para os solventes. Desta maneira, um mau solvente para um polímero pode passar a ser um bom solvente após a elevação da temperatura (HANSEN, 2007).

É importante lembrar que o próprio valor de $\alpha$ também é variável com a temperatura, assim é necessário se obter uma equação que descreva o coeficiente de expansão térmica para o solvente e realizar a integral das equações 13, 14 e 15.

\subsubsection{EFEITO DO VOLUME MOLAR E GEOMETRIA DO SOLVENTE NA SOLUBILIDADE}

Considerando-se os fenômenos de solubilidade, permeação e difusão, o tamanho da molécula (do solvente e do soluto) é um importante parâmetro, que deve ser considerado. Moléculas de volume molar menor tendem a ser mais facilmente solúveis do que moléculas maiores, que podem, inclusive, não ser solúveis em nenhuma circunstância (HANSEN, 2007). 
A teoria de solubilidade de Hildebrand estabelece que solventes com volume molar menores são melhores solventes do que solventes com volume molar maior, mesmo que possuam o mesmo valor de parâmetros de solubilidade e interajam similarmente. Outras teorias de soluções, como a teoria de Flory-Huggins para soluções de polímeros, também predizem este comportamento com relação ao volume molar das espécies. Desta maneira, em alguns casos esta condição pode ser considerada como sendo um quarto parâmetro de solubilidade (HANSEN, 2007).

Além do tamanho do solvente, a geometria do mesmo também pode influenciar em fenômenos cinéticos, como a difusão. Considerando-se a difusão, estruturas lineares possuem uma tendência de se difundirem mais rapidamente do que estruturas maiores. (HANSEN, 2007).

Entretanto, tentativas para a utilização do volume molar como parâmetro de solubilidade não foram bem sucedidas. Isto ocorre porque na maioria dos casos os efeitos de tamanho não geram diferenças termodinâmicas e sim diferenças cinéticas, logo, como os parâmetros de solubilidade são baseados na termodinâmica fica claro que a conexão entre ambas as condições é difícil. Todavia, algumas diferenças entre tamanho molecular são consideradas no parâmetro $\delta_{D}$. Isto também pode ser observado na necessidade da correção deste parâmetro para o caso de átomos de volumes molares elevados (HANSEN, 2007).

\subsection{APLICAC̣̃̃ES DE PARÂMETROS DE SOLUBILIDADE}

A solubilidade está envolvida em várias aplicações como, por exemplo, a extração e separação de componentes orgânicos e inorgânicos. Desta maneira, a uso de parâmetros de solubilidade em diferentes estudos pode ser realizada para a melhor utilização de solventes.

A aplicação mais utilizada dos parâmetros de solubilidade é a utilização no desenvolvimento de solventes para pigmentos na indústria de tintas, observado pelo grande número de patentes e trabalhos desenvolvidos na área (HANSEN, 2007).

Uma aplicação diferenciada é a de guia para a realização de extração de um composto orgânico foi realizada por Mohammad (2011), que utilizou os parâmetros de solubilidade como uma ferramenta de triagem para a predição da formação de 
co-cristais. Neste estudo foi investigada a possibilidade de solubilização de um fármaco com um co-formador para a produção de um co-cristal (fases sólidas homogêneas contendo dois ou mais componentes moleculares neutros, arranjados em uma forma cristalina). $\mathrm{O}$ autor observou que os parâmetros de solubilidade de Hansen podem ser utilizados como uma ferramenta de triagem para a verificação e escolha de co-formadores, conforme a estrutura e parâmetro de solubilidade de um fármaco (MOHAMMAD et al., 2011).

A teoria de parâmetros de solubilidade pode ser aplicada a diversos sistemas de extração, como sistemas de extração por associação de íons (FREISER, 1969), a extração de pares iônicos (IWAMOTO et al., 1983), a extração pelo uso de dióxido de carbono supercrítico (IKUSHIMA et al., 1989), extração com o uso de fluido subcrítico (SRINIVAS et al., 2009) e a extração em fase sólida (BIELICKADASZKIEWICZ et al., 2010), e de diversas matérias-primas diferentes, como o carvão (SANADA; HONDA, 1962), o betume (GUILLÉN; BLANCO, 1992), cascas de amêndoa (QUESADA-MEDINA, et al., 2010), sementes de espinheiro marítimo (Hippophae rhamnoides L.) (KAGLIWAL et al., 2011), solos (LANG et al., 2005; VILLA et al., 2011) e ligninas (Pinus caribaea hondurensis) (BALOGH et al., 1992).

Dentre os diversos compostos que são extraídos utilizando-se a teoria de parâmetros de solubilidade, o estudo de ligninas foi reportado em três publicações (SCHUERCH, 1952; BALOGH et al., 1992; QUESADA-MEDINA et al., 2010). Nos processos de deslignificação (extração de lignina) é necessário primeiramente fragmentar a lignina para então solubilizar os fragmentos de lignina, retirando-os da fase sólida. Balogh et al. (1992) determinou que a relação entre o parâmetro de solubilidade de Hildebrand dos diversos solventes e a quantidade de lignina extraída obedece a uma curva em forma de sino, conforme mostrada na figura 24. O valor obtido para o parâmetro de solubilidade de Hildebrand para a lignina situou-se no intervalo proposto anteriormente por Schuerch (1952) (20 - $\left.23 \mathrm{MPa}^{1 / 2}\right)$. 
Figura 24 - Deslignificações organossolve de diversos solventes versus parâmetro de solubilidade de Hildebrand.

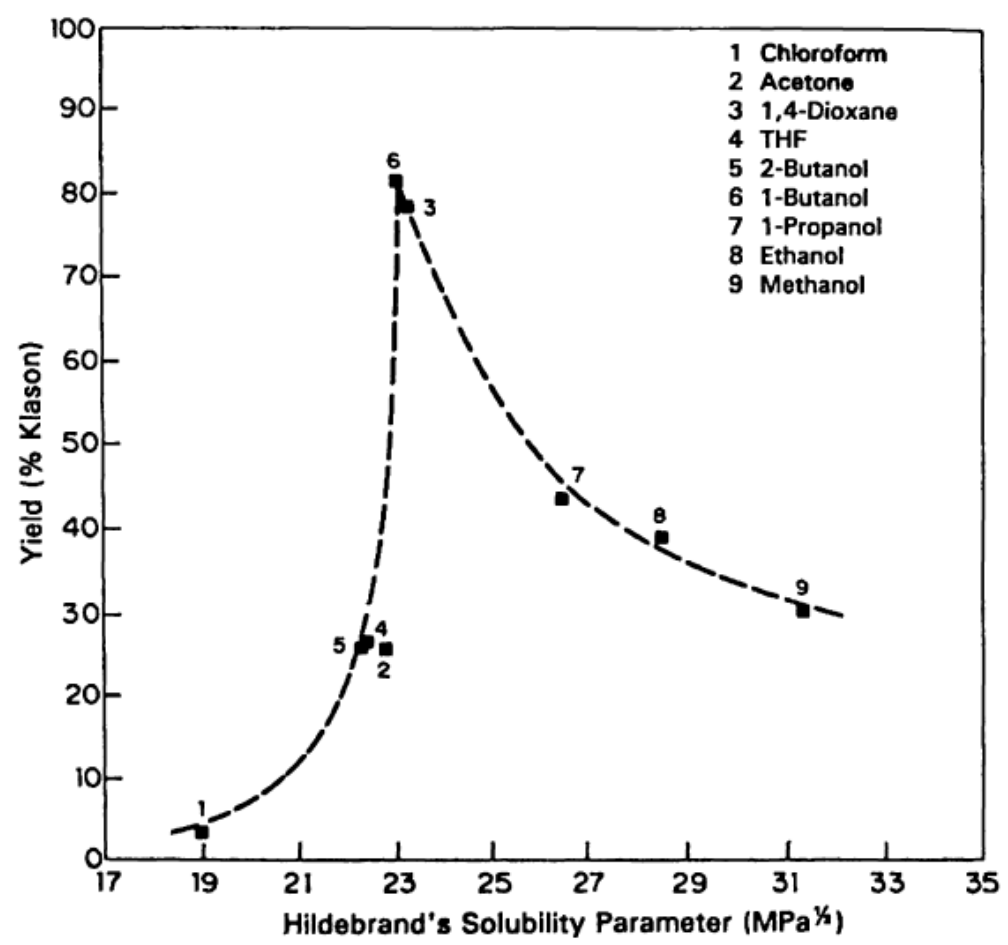

Fonte: BALOGH, D. T.; CURVELO, A. A. S.; DE GROOTE, R. A. M. C. Solvent Effects on Organosolv Lignin from Pinus caribaea hondurensis. Holzforschung, v. 46, n. 4, p. 343-348, 1992.

\subsection{JUSTIFICATIVA}

A produção de cana-de-açúcar no Brasil é muito elevada, e deverá aumentar ainda mais pelas leis de incentivo governamentais e pela tendência de crescimento da "química verde". Assim, a produção de bagaço de cana que já é elevada deverá seguir este crescimento. A biomassa vegetal possui grande possibilidade de valorização considerando-se um cenário de uma biorrefinaria, devido a composição de cerca de $75 \%$ de polissacarídeos (celulose e hemiceluloses), ela pode ser utilizada, por exemplo, na produção de etanol de segunda geração. Além da utilização dos polissacarídeos, a utilização dos outros componentes do material lignocelulósico, como a lignina, vem sendo pesquisada para aplicações diversas.

A heterogeneidade química da matéria-prima lignocelulósica dificulta a utilização direta do material assim é necessário que, para uma melhor utilização da mesma, seus componentes individuais sejam separados. No caso da utilização do 
bagaço para obtenção de glicose, através da hidrólise da celulose, estudos indicam que a presença de lignina afeta diretamente o rendimento da reação (DEMIRBAŞ, 1998). Isto ocorre pelo fato de a lignina estar fortemente associada com os demais componentes macromoleculares, o que diminui a acessibilidade em relação à celulose nos processos de hidrólise. Assim, a separação destas frações se faz necessária. Neste trabalho, buscou-se utilizar o processo de deslignificação organossolve para separar a lignina do bagaço de cana-de-açúcar.

No processo de polpação organossolve utilizam-se solventes orgânicos para a solubilização dos fragmentos de lignina. Desta maneira, a utilização de solventes, ou combinação de solventes, que permitam a maior solubilidade (e portanto, extração mais eficiente) da lignina deve ser procurada. Para isso, a teoria de parâmetros de solubilidade de Hansen foi utilizada como guia para a obtenção dos parâmetros de solubilidade de Hansen para a lignina de bagaço de cana-de-açúcar e para a obtenção de misturas entre solventes que possuíssem um valor de RED o menor possível (sempre inferior a 1,0).

No presente trabalho, para a realização das misturas de solventes, buscou-se selecionar compostos orgânicos que possuíssem baixo custo e/ou que estejam em excesso no mercado. Os solventes escolhidos foram o etanol, devido a grande produção no Brasil, e por este já ter sido muito estudado em sistemas similares, o glicerol, que é um subproduto da produção de biodiesel (outro combustível verde que vem sendo altamente pesquisado) e o 2-butanol, reagente obtido através da reação de hidratação do buteno. Os solventes também foram escolhidos considerando-se a possibilidade dos mesmos formarem boas soluções para a solubilização da lignina (parâmetros de solubilidade que ao serem combinados em proporções diferentes se aproximassem do parâmetro de solubilidade da lignina). 


\section{OBJETIVOS}

\subsection{OBJETIVOS GERAIS}

O objetivo desta pesquisa é a aplicação dos parâmetros de solubilidade de Hansen de solventes orgânicos no estudo da remoção de lignina nos processos de deslignificação organossolve em bagaço de cana-de-açúcar. Para poder chegar nesta relação, obter/verificar um parâmetro de solubilidade de Hansen adequado para descrever o polímero natural lignina de cana-de-açúcar, considerando a extensão de deslignificação para cada sistema solvente.

\subsection{OBJETIVOS ESPECÍFICOS}

Verificar o uso dos parâmetros de solubilidade como ferramenta para a avaliação da escolha de solventes orgânicos para a realização da deslignificação organossolve nas condições estudadas.

Ademais, obter misturas ternárias e quaternárias de solventes orgânicos de baixo custo e/ou excedentes no mercado (etanol, que possui elevadíssima produção no Brasil, o glicerol, subproduto da reação de transesterificação de óleos vegetais e álcoois e o 2-butanol, reagente obtido da hidratação do gás buteno) em associação com água, capazes de realizar uma deslignificação efetiva do bagaço de cana-deaçúcar, com o auxílio da ferramenta de parâmetros de solubilidade. 


\section{MATERIAIS E MÉTODOS}

\subsection{SOLVENTES E PREPARAC̣ÃO DE MATÉRIA-PRIMA}

O bagaço de cana-de-açúcar foi coletado na Usina de álcool lacanga localizada na cidade de lacanga, SP, no início de 2010, referente à safra 2009/2010. O mesmo foi coletado da maneira em que saiu da linha de produção. O bagaço coletado passou por um processo de lavagem com água a $70^{\circ} \mathrm{C}$ por uma hora, sob agitação constante, para remoção de açúcares residuais e resíduos sólidos, como areia e outras substâncias inorgânicas.

O bagaço foi espalhado para secar a temperatura ambiente, cerca de $25^{\circ} \mathrm{C}$, por cerca de uma semana, até que o mesmo possuísse uma porcentagem de umidade relativa igual a $10 \%$ em massa e foi armazenado a temperatura ambiente. Os teores de umidade foram aferidos utilizando-se uma termobalança "BEL Engeneering" da série "TopRay".

Nos procedimentos realizados, os seguintes reagentes químicos foram utilizados: acetona (Quemis); acetonitrila (J. T. Baker); ácido clorídrico (37\%) (Quemis); ácido sulfúrico (95-98\%) (Merck); etanol (J. T. Baker); metanol (Quemis); iso-propanol (Synth); 1-butanol (Mallinckrodt); 2-butanol (Oxiteno); metil-etil-cetona (Oxiteno); 1;4-dioxano (Tedia); cicloexano (Quemis); tolueno (Quemis); tetraidrofurano (J. T. Baker); glicerol bidestilado (Quemis) e hidróxido de sódio (Quemis).

\subsection{PROCESSOS DE DESLIGNIFICAC̣ÃO ORGANOSSOLVE}

Os experimentos de deslignificação foram realizados ou em um reator pressurizado "Parr" 4541 de $1 \mathrm{~L}$ de aço inox, ou em reatores com tampa de rosca de aço 304 inoxidável de volume de $195 \mathrm{~cm}^{3}(5.0 \times 4.0 \times 15.5 \mathrm{~cm})$, equipados com "orings" de politetrafluoroetileno (PTFE), um fluoropolimero resistente a elevadas 
temperaturas $\left(>250^{\circ} \mathrm{C}\right)$, como sistema de vedação. O aquecimento do reator "Parr" foi realizado através de resistências posicionadas externamente ao vaso reacional, enquanto que no caso dos reatores com tampa de rosca o aquecimento foi feito utilizando-se um banho térmico contendo glicerina como fluido de aquecimento, com sistema de agitação e controle digital de temperatura, neste caso os reatores foram imersos no banho somente quando o fluido já estivesse na temperatura desejada (BALOGH, 1989; NOVO et al., 2011).

Para cessar a reação com o tempo reacional estipulado, em ambos os casos os reatores foram colocados imediatamente em um banho de água com gelo. Após o resfriamento dos reatores, as polpas foram separadas dos licores de polpação através de filtração a pressão reduzida. Os licores foram coletados e armazenados a -5ํㅡ para posterior recuperação das ligninas, já as polpas passaram por um procedimento de desfibramento, no qual as fibras celulósicas são separadas umas das outras, ou com uma solução de água e o solvente orgânico utilizado na deslignificação ou com uma solução 1\% de hidróxido de sódio (em massa), para remoção de fragmentos de lignina adsorvidos nas fibras de bagaço (PASQUINI et al., 2005). O processo de desfibramento foi feito utilizando um desfibrador de pás de 3L, por cerca de um minuto e meio. Após esse procedimento, as polpas foram filtradas a pressão reduzida e então lavadas com água até a obtenção de um filtrado com pH neutro ou não haver resquícios de solvente orgânico. As polpas foram, então, secas a temperatura ambiente até uma umidade inferior a 10\% (BALOGH, 1989; NOVO et al., 2011).

Após a verificação da massa final e da umidade, as polpas passaram por um moinho de facas "Solab" SL31, equipado com uma tela de 40 mesh e armazenadas a temperatura ambiente.

\subsubsection{CARACTERIZAÇÃO DAS DESLIGNIFICAÇÕES ORGANOSSOLVE}

As reações de deslignificação foram caracterizadas de três maneiras: 1) pela determinação do rendimento gravimétrico $(Y)$; 2) pela determinação da porcentagem de lignina imiscível e miscível em ácido $(K L)$, através do método lignina Klason modificado, das polpas residuais; 3) e pela porcentagem de deslignificação. 


\subsubsection{RENDIMENTO GRAVIMÉTRICO}

O rendimento gravimétrico consiste em uma razão entre as massas secas inicial e final, conforme a equação 16.

$$
Y(\%)=100 \times\left(\frac{m_{f i n a l}^{\text {seca }}}{m_{\text {inicial }}^{\text {secal }}}\right) \quad \text { Equação } 16
$$

O rendimento gravimétrico é um indicativo da extensão da reação porém o mesmo não fornece, isoladamente, nenhum indicativo de quais frações são removidas, nem de quais reações ocorreram, desta maneira análises adicionais são necessárias.

\subsubsection{MÉTODO KLASON MODIFICADO}

O método Klason também é uma análise gravimétrica, mas que, diferencialmente do rendimento gravimétrico, fornece indicações de quais componentes foram removidos.

O método Klason envolve duas etapas. A primeira consiste em uma reação de hidrólise de ligações éter e glicosídicas e é realizada a temperatura de cerca de $25^{\circ} \mathrm{C}$ em solução com ácido sulfúrico concentrado. A segunda etapa é realizada sob refluxo após diluição da solução ácida. Nesta etapa a hidrólise é finalizada e grupos sulfato incorporados ao substrato são eliminados. Nesta etapa pode ainda ocorrer condensação entre fragmentos de lignina. $O$ tratamento completo resulta em um sólido imiscível (lignina imiscível) e a uma solução contendo os açúcares, ou oligômeros de polissacarídeos, os produtos de degradação da reação e uma pequena fração de lignina miscível.

Para a realização do método Klason original utiliza-se uma massa seca inicial de $1 \mathrm{~g}$ ou de $2 \mathrm{~g}$ (dependendo se a amostra é de matéria-prima "in natura" ou se é uma matéria-prima já deslignificada, respectivamente) de material moído com uma granulometria de cerca de 40 mesh (inferior a $0,4 \mathrm{~mm}$ ), enquanto que o método 
Klason modificado foi realizado utilizando-se uma massa seca de $800 \mathrm{mg}$ de material lignocelulósico, independentemente se é um material deslignificado ou não. No método modificado o material usado também foi moído a cerca de 40 mesh.

Adicionou-se, então, uma solução $72 \%$ em massa de ácido sulfúrico à massa pesada inicialmente e deixou-se reagir, sob agitação constante, por um período de duas horas. No caso da realização do método original, adiciona-se $15 \mathrm{~mL}$ ou $40 \mathrm{~mL}$ (para as massas de material "in natura" e deslignificado, respectivamente) à massa inicial em um erlenmeyer, enquanto que o método modificado foi realizado adicionando-se $12 \mathrm{~mL}$ em um tubo de $500 \mathrm{~mL}$ (apropriado para suportar as pressões e temperaturas de uma autoclave), e deixando-se reagir sob agitação pelo mesmo período de duas horas.

$\mathrm{Na}$ segunda etapa do método Klason, adiciona-se água para diluição para solução final 3\% em massa de ácido sulfúrico e aquece-se a solução para realizar a hidrólise catalisada por ácido. Para a realização do método original adiciona-se ou $560 \mathrm{~mL}$ ou $1520 \mathrm{~mL}$ (para as massas de material "in natura" e deslignificado, respectivamente) e aquece-se até a ebulição em refluxo por um período de quatro horas. Já o método modificado foi realizado adicionando-se uma quantidade de $450 \mathrm{~mL}$ de água ao tubo (resultando na mesma concentração de $3 \%$ em massa de ácido sulfúrico) e este foi, então, fechado e na autoclave levado até uma temperatura de aproximadamente $120^{\circ} \mathrm{C}$ e uma pressão interna de 2 bar, por um período de uma hora. No método original para se realizar a próxima etapa de filtração, espera-se a solução esfriar até a temperatura próxima a ambiente, enquanto que no procedimento modificado os tubos foram resfriados até $25 \stackrel{\circ}{ } \mathrm{C}$ com o auxílio de água e gelo, após a despressurização da autoclave.

$\mathrm{Na}$ etapa de filtração do sólido residual, não há diferença entre o método original e o procedimento modificado. Assim, as fases foram separadas utilizando-se um funil com placa sinterizada ASTM 10-15 calcinado e tarado, e o sólido resultante foi lavado com água. O volume final da solução filtrada foi verificado utilizando-se um balão volumétrico. Para o método modificado, o volume verificado final correspondeu a $500 \mathrm{~mL}$. O funil de placa sinterizada contendo a lignina foi então secado a 90$100^{\circ} \mathrm{C}$ em uma estufa por um período de 12 horas, transferido para um dessecador e pesado até peso constante. Obteve-se o valor de massa de lignina imiscível por diferença com relação ao funil de placa sinterizada tarado. 
Após este procedimento, o funil de placa sinterizada foi novamente calcinado, obtendo-se desta maneira a quantidade de cinzas para corrigir o valor de lignina imiscível residual. Os procedimentos de calcinação foram realizados a $525^{\circ} \mathrm{C}$ por 4 horas, com uma rampa de aquecimento da mufla de $100^{\circ} \mathrm{C} \cdot \mathrm{h}^{-1} \mathrm{em}$ uma mufla "EDG" de volume interno igual a $4,5 \mathrm{~L}$ e aquecimento por resistências. Da mesma maneira que a massa de lignina imiscível residual foi determinada, as massas de cinzas também foram determinadas pela diferença entre o funil de placa sinterizada contendo as cinzas em relação ao funil de placa sinterizada tarado. $O$ valor de lignina imiscível em ácido foi então calculado pela equação 17 abaixo.

$$
K L(\%)=\left(\frac{m_{\text {Lignina insolúvel }}-m_{\text {cinzas }}}{m_{\text {biomassa }}^{\text {seca }}}\right) \quad \text { Equação } 17
$$

As quantidades de lignina miscível nas reações Klason foram determinadas através da determinação das absorbâncias no UV-Vis, utilizando-se a equação 18 (GOLDSCHIMID, 1971). Os espectros de UV-Vis foram obtidos no intervalo de 190 a 320nm utilizando um aparelho Espectrofotômetro de UV-Vis "Hach" DR-5000 em uma cela de quartzo polido de $10 \mathrm{~mm}$ de espessura.

$$
\operatorname{Lignina}_{\text {solúvel }}(\%)=\frac{\left(4,53 \times A_{215}-A_{280}\right) \times V_{f} \times F_{\text {Fator }} \text { Diluição }}{3 \times m_{\text {biomassa }}} \quad \text { Equação } 18
$$

$\mathrm{Na}$ equação 18, $A_{215}$ corresponde à absorbância em 215nm, $A_{280}$ corresponde à absorbância no pico entorno de $280 \mathrm{~nm}, V_{f}$ o volume aferido da

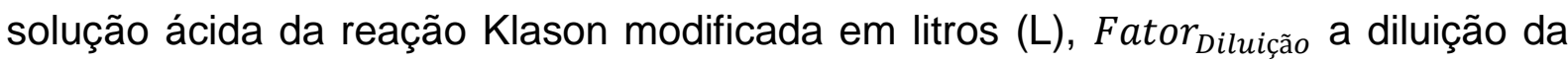
solução na qual foi registrado o espectro e $m_{\text {biomassa }}$ a massa seca de biomassa de entrada na reação Klason. O fator de diluição das medidas realizadas foi igual a 10.

A equação 18 é uma correção à equação clássica utilizada para a verificação da lignina miscível em ácido, visto que a mesma considera para o cálculo da lei de Beer ou o pico em torno de 200nm (no caso do bagaço, absorbância em $215 \mathrm{~nm}$ ) ou o pico em torno de $280 \mathrm{~nm}$ e suas absortividades, sendo que o primeiro é melhor utilizável, visto que no segundo existe uma grande interferência de produtos de degradação que também absorvem nesta faixa de comprimento de onda, como os produtos da degradação de carboidratos furfural e 5-hidroximetilfurfural. Até 1989 o 
calculo da lei de Beer era realizado utilizando-se o valor da absorbância em 205nm, porém com a publicação do trabalho de Maekawa et al. (1989) foi verificado que para madeiras duras de fato o melhor ponto para absorção é no comprimento de onda de $205 \mathrm{~nm}$ mas para madeiras moles, bambu e outras monocotiledôneas, como a cana-de-açúcar, verificou-se que o melhor seria utilizar o comprimento de onda correspondente ao máximo do pico ao redor de 200nm (LIN; DENCE, 1992).

A lignina residual total corresponde a soma da lignina residual imiscível em ácido e a lignina residual miscível em ácido, conforme a equação 19.

$$
\text { Lignina }_{\text {total }}=K L+\text { Lignina }_{\text {solúvel }} \quad \text { Equação } 19
$$

\subsubsection{PORCENTAGEM DE DESLIGNIFICACÃ̃O}

A porcentagem de deslignificação foi determinada utilizando-se a equação 20. $\mathrm{Na}$ equação 20 , verifica-se o uso do produto entre o rendimento e a lignina total na polpa, isto ocorre para corrigir a mudança de base de massa para o cálculo, transformando o valor de lignina total em massa na mesma base inicial (PASQUINI et al., 2005; NOVO et al., 2011).

$$
\text { Deslignificação }(\%)=\left(\frac{\text { Lignina }_{\text {total }}^{\text {bagaco integral }}-\left(\text { Lignina }_{\text {total }}^{\text {polpa }} \times \frac{Y^{p o l p a}}{100}\right)}{\text { Lignina }_{\text {total }}^{\text {bagaco integral }}}\right) \times 100 \text { Equação } 20
$$

\subsubsection{DETERMINAÇÃO DE PROCEDIMENTO E CONDIÇÕES REACIONAIS}

Considerando a necessidade de uma padronização do procedimento, buscouse obter uma condição reacional intermediária única, que não fosse nem muito drástica nem muito branda, a ponto de indiferenciar ou bom solvente de um mau solvente, para a realização das deslignificações organossolve com os diferentes solventes. Para isso, testes foram realizados utilizando-se etanol (um solvente 
intermediário para lignina, ou seja, que não é excelente em remover lignina, porém também consegue removê-la), 1,4-dioxano (historicamente o melhor solvente para extração de lignina, sendo usado inclusive como um solvente para extração de lignina padrão, conhecida por lignina Pepper) e acetona (um mau solvente para lignina) (SCHUERCH, 1952; PEPPER et al., 1959; BALOGH, 1989; EVTUGUIN et al., 2001; HU, 2008). Considerando-se o objetivo de se verificar a relação entre os parâmetros de solubilidade dos solventes e as deslignificações, estabeleceu-se uma razão solvente orgânico/água igual a 9/1, mantendo os parâmetros de solubilidade mais próximos dos de um solvente puro (ver "equação 4", item 1.4.1).

Nos testes iniciais, buscou-se variar a razão sólido/liquido, a temperatura e o tempo reacional, sem o uso de qualquer catalisador inorgânico externo, buscando resultados similares aos obtidos por Balogh (1989), trabalho que utilizava como matéria-prima serragem com 24 mesh de Pinus caribaea hondurensis, utilizando uma condição similar à condição reacional da extração Pepper (125드, seis horas, razão sólido/líquido igual a $1 / 10$ e razão solvente orgânico/água igual a 9/1, com concentração final de $0,2 \mathrm{~mol} . \mathrm{L}^{-1}$ de $\mathrm{HCl}$ como catalizador).

$\mathrm{Na}$ primeira etapa de testes estabeleceu-se a condição de razão sólido líquido, mantendo condições de temperatura, tempo e razão solvente orgânico/água, utilizando os reatores de tampa de rosca. Para isso, seis reações utilizando uma solução etanol/água foram realizadas, variando razões sólido/líquido entre 1/6 e 1/15, baseado em resultados preliminares do grupo. Fixou-se a razão sólido/líquido em 1/10, considerando os resultados e para facilidade de comparação.

Em uma segunda etapa, mantendo a então fixada razão sólido/líquido, usando o reator "Parr", variou-se as condições de tempo e temperatura para as soluções de etanol/água e 1,4-dioxano/água. Como o intuito inicial do trabalho seria não utilizar nenhuma fonte de catalisador externo, buscou-se elevar a temperatura, para tornar o processo cineticamente viável. Os testes foram realizados utilizando-se variações de temperatura entre 130 e $190^{\circ} \mathrm{C}$, enquanto as variações de tempo ocorreram entre uma e quatro horas. Tempos maiores não foram realizados, pois resultados preliminares do grupo indicavam que esta variável é pouco influente no caso de polpações organossolve de bagaço de cana-de-açúcar (PASQUINI et al., 2005; NOVO et al., 2011). 
Após a segunda etapa, verificou-se a necessidade da adição de um catalizador ácido para que a diferenciação das amostras pudesse ocorrer. Desta maneira, observando as condições reacionais de Balogh (1989) testes foram realizados variando-se a concentração de ácido clorídrico adicionado à reação, de uma concentração da solução final de $0,2 \mathrm{~mol} . \mathrm{L}^{-1}$ a $0,05 \mathrm{~mol} \cdot \mathrm{L}^{-1}$ de $\mathrm{HCl}$. Para estes testes utilizou-se soluções de razão solvente orgânico/água igual a $1 / 9$ dos solventes etanol, 1,4-dioxano e acetona, a temperatura igual a $125^{\circ} \mathrm{C}$ e $\mathrm{O}$ tempo de uma hora.

Ao final da fase de testes determinou-se que a condição experimental para a realização dos experimentos de deslignificação seria: razão solvente orgânico/água igual a $1 / 9$; temperatura igual a $125^{\circ} \mathrm{C}$; tempo igual a uma hora; razão sólido/líquido igual a 1/10; e concentração de catalizador na solução final igual a $0,05 \mathrm{~mol} . \mathrm{L}^{-1}$ de $\mathrm{HCl}$.

Verificou-se, durante a elaboração dos testes para a determinação da condição reacional, o procedimento de lavagem e desfibramento das polpas. Para isto, parte da polpa obtida por um processo de deslignificação foi lavada exaustivamente com o solvente orgânico utilizado na polpação, utilizando-se um extrator "soxlet", e desfibrada, enquanto a outra parte da polpa foi desfibrada com uma solução 1\% em massa de hidróxido de sódio e depois lavada com água até a solução de lavagem estar com pH neutro. Comparou-se, então, os resultados de deslignificação de ambos os tratamentos, e escolheu-se o procedimento utilizando a solução 1\% de hidróxido de sódio como procedimento padrão.

3.2.3 PARÂMETROS DE SOLUBILIDADE DE LIGNINA DE BAGAÇO DE CANA-DE-AÇÚCAR

\subsubsection{DESLIGNIFICACCÕES ORGANOSSOLVE}

A figura 25 mostra o fluxograma de etapas definido como padrão para as deslignificações organossolve para a determinação dos parâmetros de solubilidade de Hansen para a lignina de bagaço de cana-de-açúcar. 
Figura 25 - Fluxograma de etapas padrão.

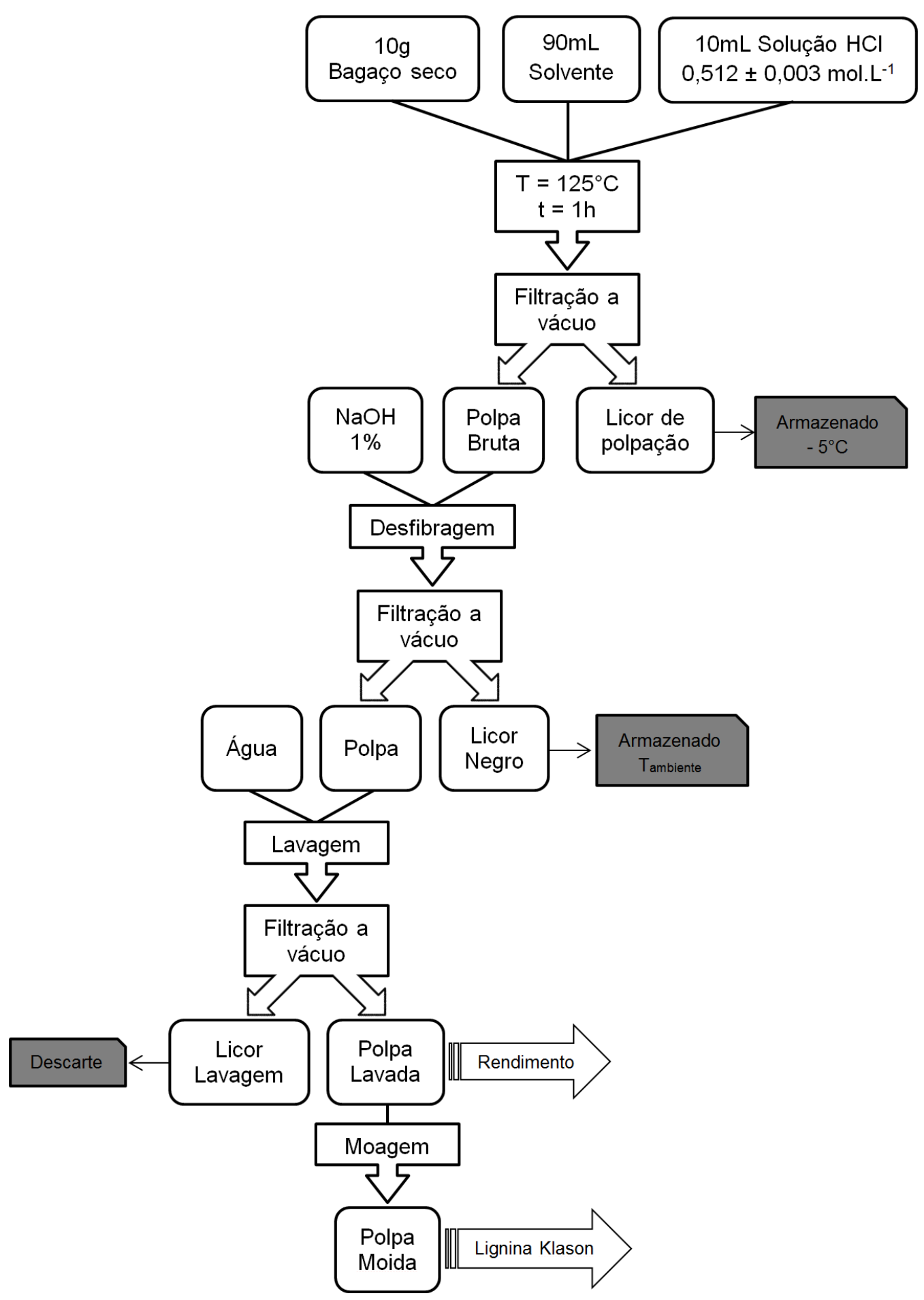

Utilizou-se como solventes para as deslignificações organossolve os seguintes solventes: acetona; acetonitrila; 2-butanol; cicloexano; 1,4-dioxano; etanol; isopropanol; metanol; metil-etil-cetona; 1-butanol; tetraidrofurano e tolueno. Realizou-se, também, uma reação utilizando água como solvente. As reações foram realizadas utilizando os reatores com tampa de rosca. 


\subsubsection{OBTENCCÃO DOS PARÂMETROS DE SOLUBILIDADE}

A obtenção dos parâmetros de solubilidade de Hansen para a lignina de bagaço de cana-de-açúcar foi realizada utilizando o programa desenvolvido por Gharagheizi (2007) para o software MatLab (a programação pode ser verificada no Anexo 1).

Este é um programa que se utiliza do mesmo algoritmo para o cálculo dos parâmetros de solubilidade utilizado no programa desenvolvido por Hansen (2007), porém, utilizando pequenas alterações que resultam em respostas mais precisas do programa (GHARAGHEIZI, 2007).

Nestes programas, um banco de dados é fornecido para a realização dos cálculos relacionados ao algoritmo. Este banco de dados contém o número de solventes utilizados, os parâmetros de solubilidade para este conjunto de solventes e a solubilidade do substrato nos mesmos. A solubilidade do substrato em cada solvente é expressa na forma de um valor igual a " 1,0 " ou igual a " 0 ", sendo que para o primeiro o substrato é miscível no solvente e no segundo não (GHARAGHEIZI, 2007; HANSEN, 2007).

A solubilidade do substrato em um dado solvente depende do que é estabelecido pelo usuário, podendo ocorrer a formação de uma solução propriamente dita ou não. A solubilidade pode ser determinada de diversas maneiras, como por uma determinada porcentagem de inchamento ou de absorção do solvente pelo polímero, ou por ocorrer uma ruptura do substrato em tempo menor do que em um dado intervalo, pelo fato de o coeficiente de permeação ser superior a um valor determinado, pela suspensão de um pigmento por um longo período, e assim por diante. Desta maneira, relacionou-se a porcentagem de deslignificação das reações utilizando diferentes solventes com a solubilidade da lignina nestes solventes (GHARAGHEIZI, 2007; HANSEN, 2007).

Para os estudos realizados, desconsiderou-se a variação dos parâmetros de solubilidade com a temperatura, visto que muitos dos valores de coeficiente de expansão térmica para a faixa de temperatura utilizada não estão disponíveis para a consulta na literatura.

Foram realizadas cinco corridas do programa, utilizando porcentagens de deslignificação mínimas diferentes para a determinação da solubilização ou não 
solubilização. Assim, qualquer solvente com uma deslignificação superior ao valor designado como deslignificação mínima possuiu um valor "1.0" (solúvel) inserido no banco de dados, enquanto qualquer solvente com valor de deslignificação inferior ao de deslignificação mínima possuiu um valor "0" (insolúvel) inserido no programa.

A presença de água nas soluções de polpação (em todos os casos existem $10 \%$ em volume de água) altera os valores dos parâmetros de solubilidade dos solventes orgânicos puros, para os casos em que a água é miscível no solvente orgânico, conforme indicado na equação 4. Desta maneira, para os solventes miscíveis com água, utilizou-se no banco de dados os parâmetros de solubilidade considerando uma solução de $90 \%$ de solvente orgânico e $10 \%$ de água (em volume). Na tabela 2 observam-se os parâmetros de solubilidade dos solventes puros e das soluções, nos casos onde há miscibilidade entre o solvente orgânico e água.

Tabela 02 - Parâmetros de solubilidade de Hansen para os solventes puros e para as soluções utilizadas nas deslignificações.

\begin{tabular}{ccccccc}
\hline & \multicolumn{3}{c}{ Solventes Puros } & \multicolumn{3}{c}{ Soluções com 10\% de água } \\
Solvente principal & $\boldsymbol{\delta}_{\boldsymbol{d}}$ & $\boldsymbol{\delta}_{\boldsymbol{p}}$ & $\boldsymbol{\delta}_{\boldsymbol{h}}$ & $\boldsymbol{\delta}_{\boldsymbol{d}}$ & $\boldsymbol{\delta}_{\boldsymbol{p}}$ & $\boldsymbol{\delta}_{\boldsymbol{h}}$ \\
\hline tolueno & 18 & 1,4 & 2 & --- & --- & --- \\
cicloexano & 16,8 & 0 & 0,2 & --- & --- & --- \\
metil-etil-cetona & 16 & 9 & 5,1 & 15,95 & 9,7 & 8,82 \\
tetraidrofurano & 16,8 & 5,7 & 8 & 16,67 & 6,73 & 11,43 \\
1,4-dioxano & 19 & 1,8 & 7,4 & 18,65 & 3,22 & 10,89 \\
metanol & 15,1 & 12,3 & 22,3 & 15,14 & 12,67 & 24,3 \\
etanol & 15,8 & 8,8 & 19,4 & 15,77 & 9,52 & 21,69 \\
isopropanol & 15,8 & 6,1 & 16,4 & 15,77 & 7,09 & 18,99 \\
1-butanol & 16 & 5,7 & 15,8 & 15,95 & 6,73 & 18,45 \\
2-butanol & 15,8 & 5,7 & 14,5 & 15,77 & 6,73 & 17,28 \\
água & 15,5 & 16 & 42,3 & --- & --- & --- \\
acetonitrila & 15,3 & 18 & 6,1 & 15,32 & 17,8 & 9,72 \\
acetona & 15,5 & 10,4 & 7 & 15,50 & 10,96 & 10,53 \\
\hline
\end{tabular}

Fonte: BARTON, A. Handbook of Solubility Parameters and Other Cohesion Parameters. 1 st. ed. CRC Press, 1983. (Adaptado) 


\subsubsection{VERIFICACÃO DOS PARÂMETROS DE SOLUBILIDADE DE LIGNINA DE BAGACCO}

Para a verificação dos parâmetros de solubilidade obtidos para a lignina de bagaço de cana-de-açúcar foram realizados quatro testes de deslignificação com as mesmas condições experimentais aplicadas na seção de obtenção dos parâmetros de solubilidade para a lignina de bagaço, incluindo a porcentagem em volume adicionada de água. Destes testes, três foram feitos com misturas ternárias de solventes (dois solventes orgânicos e água), enquanto o quarto teste foi feita uma mistura quaternária (três solventes orgânicos e água).

Os solventes orgânicos foram escolhidos considerando o uso de solventes de baixo custo e/ou excedentes no mercado brasileiro que pudessem formar misturas com parâmetros de solubilidade inseridos na esfera de solubilidade da lignina. Desta maneira, escolheu-se o etanol, que possui elevadíssima produção no Brasil, o glicerol, subproduto da produção de biodíesel, e o 2-butanol, reagente obtido pela hidratação do gás buteno.

As razões utilizadas entre os volumes dos solventes orgânicos nas misturas ternárias foram determinadas considerando-se as razões que possuíssem os menores valores de $R_{a}$ e de RED considerando todas as corridas realizadas no programa e os parâmetros de solubilidade para a lignina verificados na literatura. Nas figuras 26, 27 e 28 pode-se observar a variação dos parâmetros de solubilidade, a variação de $R_{a}$ e de $R E D$, respectivamente, para cada mistura com relação à variação da razão volumétrica entre solventes orgânicos. Nas figuras 27 e 28 os índices "1" a "5" correspondem ao valor em relação à esfera de solubilidade obtida em cada corrida realizada no programa MatLab, e o índice "Lit" em relação a esfera obtida na literatura. 
Figura 26 - Variação dos parâmetros de solubilidade versus razão volumétrica entre os solventes orgânicos.
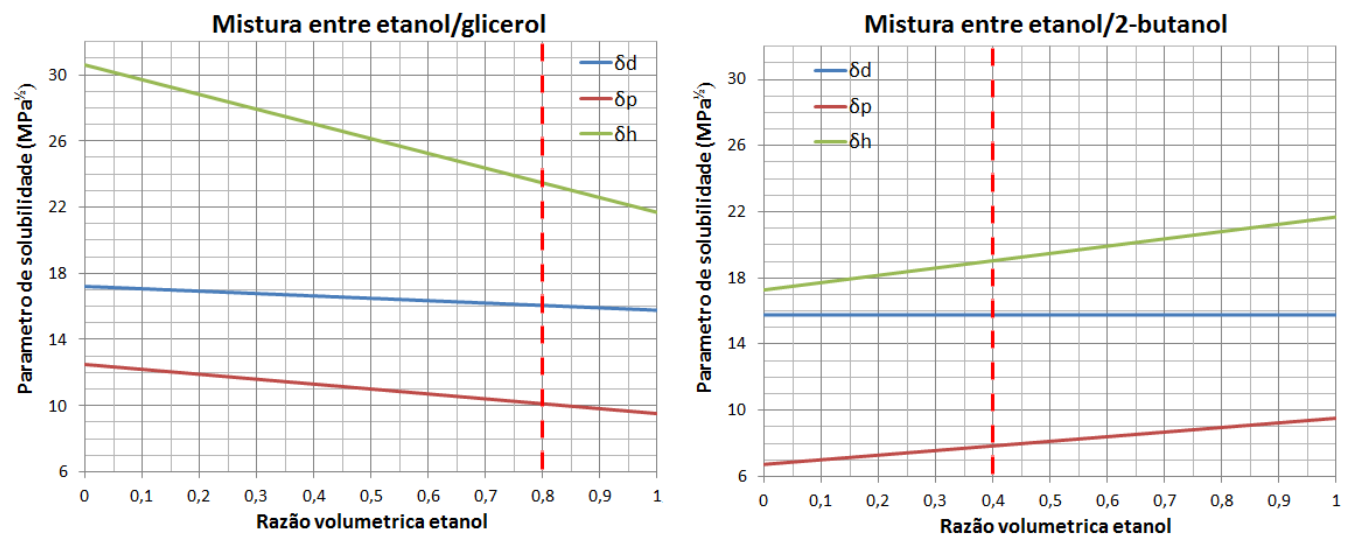

Mistura entre glicerol/2-butanol

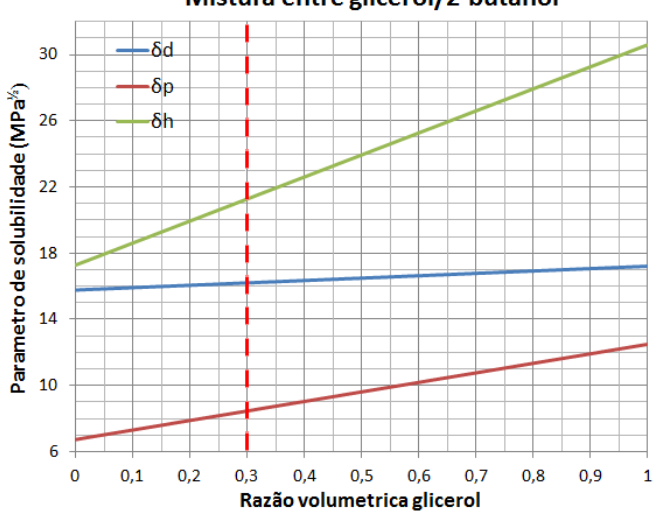

Figura 27 - Variação de $R_{a}$ versus razão volumétrica entre os solventes orgânicos.
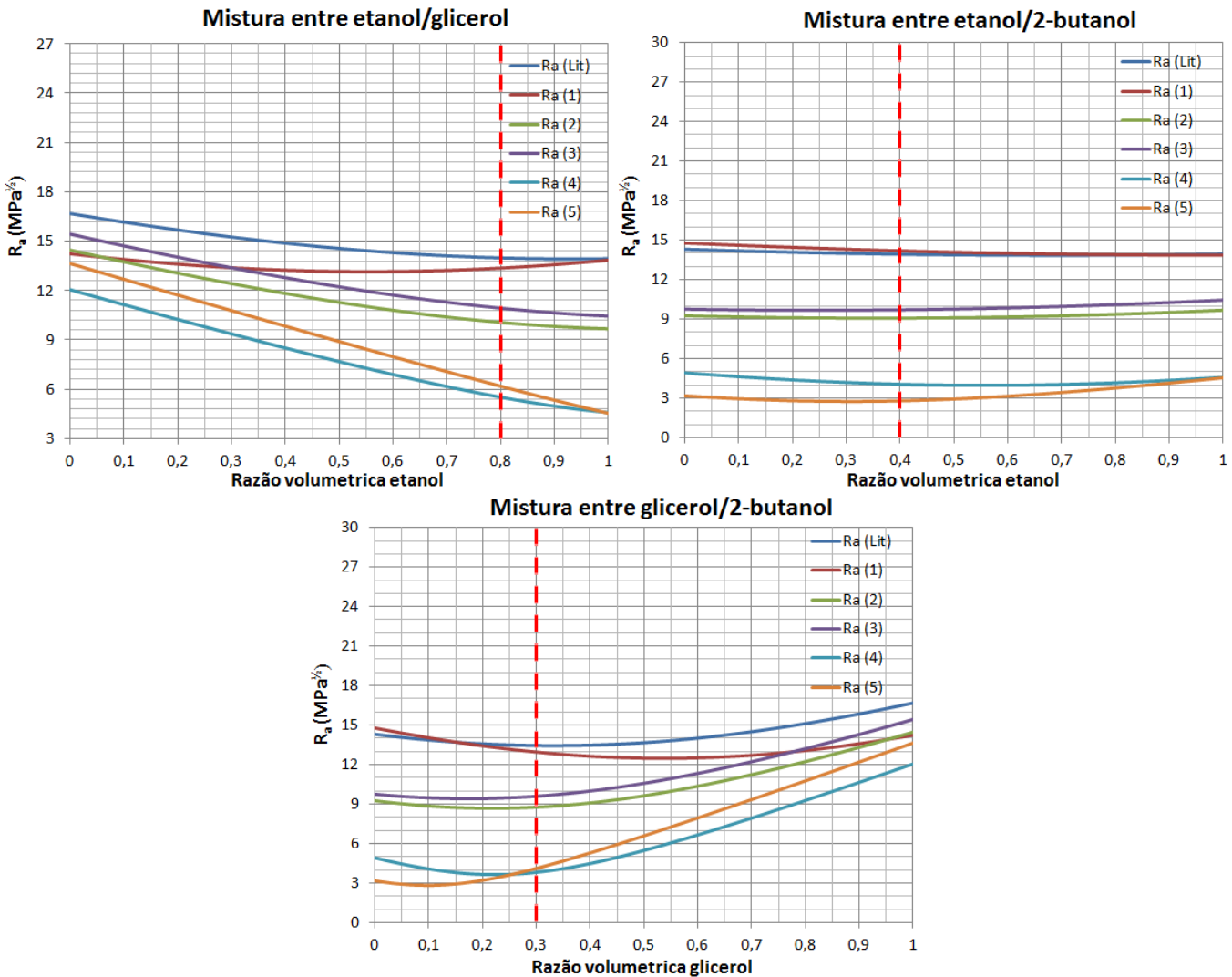
Figura 28 - Variação de $R E D$ versus razão volumétrica entre os solventes orgânicos.
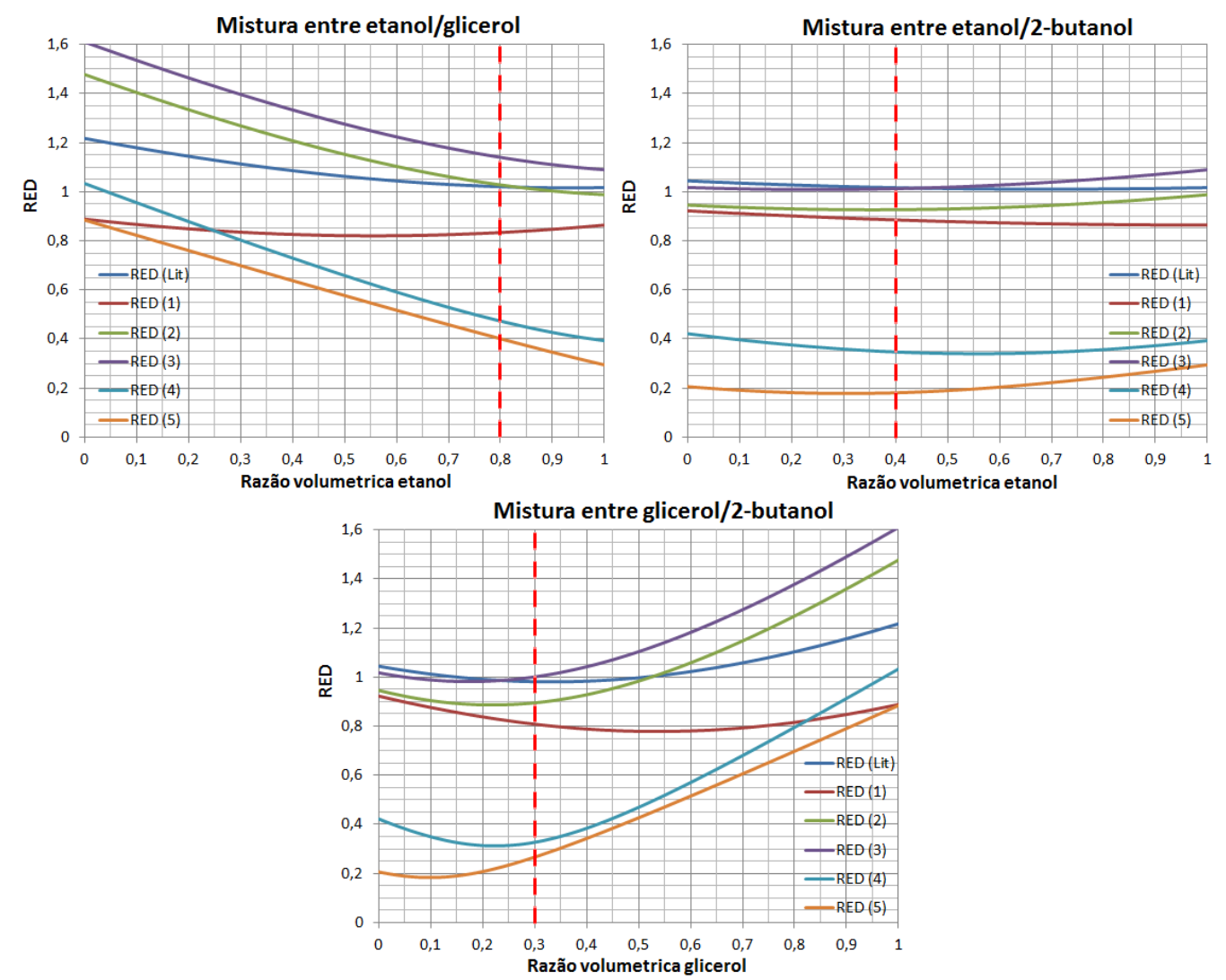

As razões volumétricas dos solventes orgânicos para as misturas ternárias utilizadas nos testes foram: etanol/glicerol, razão 80/20; etanol/2-butanol, razão 40/60; e glicerol/2-butanol, razão 30/70. Para o teste quaternário, a razão volumétrica entre os solventes orgânicos (etanol/glicerol/2-butanol) foi estabelecida como sendo 1/1/1. Em todos os testes a razão volumétrica entre o solvente orgânico e a água foi de $90 \%$ de solvente orgânico e $10 \%$ de água. 


\section{RESULTADOS E DISCUSSÃO}

\subsection{RESULTADOS DAS REAC̣ÕES DE DESLIGNIFICAĈ̣̃O}

Os resultados obtidos na fase de determinação dos parâmetros reacionais podem ser verificados na tabela 03. Nesta tabela, os testes indicados como "a" e "b" correspondem aos testes realizados com a etapa de lavagem exaustiva com 0 solvente orgânico utilizado na polpação e com a etapa de lavagem com a solução $1 \%$ em massa de hidróxido de sódio, respectivamente, enquanto que os demais testes, não acompanhados de letras, ou não foi realizado a obtenção do valor de lignina imiscível ou foi feita somente a lavagem com solução de $\mathrm{NaOH}$.

Tabela 03 - Resultados dos testes para definição das condições reacionais para a deslignificação.

\begin{tabular}{|c|c|c|c|c|c|c|}
\hline \multirow[b]{2}{*}{ Teste } & \multicolumn{4}{|c|}{ Condições Reacionais } & \multirow[b]{2}{*}{$\begin{array}{c}\text { Rendimento } \\
\text { (\%) }\end{array}$} & \multirow[b]{2}{*}{$\begin{array}{l}\text { Lignina Insolúvel } \\
\text { (\%) }\end{array}$} \\
\hline & $\begin{array}{c}\text { Temperatura } \\
\left({ }^{\circ} \mathrm{C}\right)\end{array}$ & $\begin{array}{c}\text { Tempo } \\
\text { (min) }\end{array}$ & $\begin{array}{l}\text { Solvente } \\
\text { Principal }\end{array}$ & $\begin{array}{l}\text { C. Ácido } \\
\text { (mol. } \text { (-1) }^{-1}\end{array}$ & & \\
\hline 1 & 130 & 60 & etanol & --- & 95,93 & --- \\
\hline $\begin{array}{l}2 . a \\
2 . b\end{array}$ & 150 & 60 & etanol & --- & 95,59 & $\begin{array}{c}19,0 \\
19,15\end{array}$ \\
\hline $\begin{array}{l}3 . a \\
3 . b\end{array}$ & 150 & 60 & 1,4-dioxano & --- & 94,21 & $\begin{array}{l}19,5 \\
19,7\end{array}$ \\
\hline 4 & 170 & 60 & etanol & --- & 88,36 & --- \\
\hline 5 & 170 & 60 & 1,4-dioxano & --- & 87,27 & --- \\
\hline $\begin{array}{l}6 . a \\
6 . b\end{array}$ & 170 & 240 & etanol & --- & 82,66 & $\begin{array}{l}16,25 \\
16,65\end{array}$ \\
\hline $\begin{array}{l}\text { 7.a } \\
7 . b\end{array}$ & 170 & 240 & 1,4-dioxano & --- & 82,30 & $\begin{array}{l}17,55 \\
17,05\end{array}$ \\
\hline 8 & 190 & 240 & etanol & --- & 60,33 & 11,85 \\
\hline 9 & 190 & 240 & 1,4-dioxano & --- & 70,63 & 14,90 \\
\hline 10 & 125 & 240 & etanol & 0,2 & 47,95 & --- \\
\hline 11 & 125 & 240 & 1,4-dioxano & 0,2 & 34,48 & --- \\
\hline 12 & 125 & 60 & etanol & 0,2 & 51,62 & 3,25 \\
\hline 13 & 125 & 60 & 1,4-dioxano & 0,2 & 43,77 & 1,92 \\
\hline 14 & 125 & 60 & etanol & 0,1 & 59,14 & 7,67 \\
\hline 15 & 125 & 60 & 1,4-dioxano & 0,1 & 45,83 & 2,03 \\
\hline 16 & 125 & 60 & acetona & 0,1 & 54,18 & 9,33 \\
\hline 17 & 125 & 60 & etanol & 0,05 & 61,51 & 9,21 \\
\hline 18 & 125 & 60 & 1,4-dioxano & 0,05 & 49,48 & 4,86 \\
\hline 19 & 125 & 60 & acetona & 0,05 & 59,23 & 12,08 \\
\hline
\end{tabular}


Pode-se observar que para os primeiros testes (1, 2, 3, 4 e 5) os rendimentos das reações de deslignificação são muito elevados, ou seja, praticamente não houve perda de massa significativa e, portanto, não ocorreu a remoção de lignina. Assim, viu-se necessário deixar as condições reacionais mais severas, porém, visto que com a elevação da temperatura ocorre a variação dos parâmetros de solubilidade, para não os alterar tanto, decidiu-se elevar o tempo de reação, de 60 para 240 minutos. Com esta alteração, testes 6 e 7, não observou-se diferença significativa entre as respostas fornecidas para os diferentes solventes, obrigando novamente a tornar a reação mais severa, neste caso subindo a temperatura de 170 para 190ㄷ. $\mathrm{Na}$ temperatura de $190^{\circ} \mathrm{C}$, testes 8 e 9, observou-se inversão com respeito ao melhor solvente para a lignina (esperava-se que o 1,4-dioxano levasse a uma maior perda de massa). Portanto, apesar da obtenção de uma diferenciação entre os resultados de deslignificação, esta condição reacional ainda não estava adequada.

Assim, após esta etapa de testes, verificou-se que a ausência de um catalisador externo para a deslignificação organossolve de bagaço de cana-deaçúcar pode levar à deslignificação, porém não permitiu a diferenciação entre solventes diferentes, com relação aos parâmetros de solubilidade.

Nos primeiros testes utilizando catalizador, testes 10 e 11, observou-se uma degradação muito elevada do material lignocelulósico, podendo ser verificado pelo rendimento muito baixo (para a deslignificação com 1,4-dioxano, observou-se uma massa residual de apenas $34,5 \%$, sendo que cerca de $44 \%$ da massa inicial seca correspondem à celulose). Desta maneira viu-se necessário a diminuição do tempo reacional.

Comparando os testes 10 e 11 com os testes 12 e 13, verifica-se a pequena contribuição do tempo para a extensão da reação de deslignificação, visto que uma diminuição do tempo de reação de 4 para 1 hora leva a um aumento no rendimento apenas de $8 \%$, para o caso do 1,4-dioxano. Observou-se, contudo, que houve menor degradação da polpa lignocelulósica. Esta observação é condizente com resultados obtidos por Pasquini et al. (2005). Desta maneira, com o uso de catalisadores, tempos superiores a 60 minutos são indesejáveis para reações de deslignificação organossolve por levar a degradação da fração celulósica da polpa. Ademais, observou-se ainda a necessidade da diminuição da severidade da reação. Para isto, duas situações poderiam ocorrer, a primeira seria diminuir a concentração de ácido adicionado na solução inicial, ou a segunda seria diminuir a temperatura. 
Considerando uma homogeneidade entre os testes, uma diminuição na temperatura não seria ideal, visto que com isto a condição reacional para alguns solventes estaria acima da temperatura de ebulição e para outros solventes abaixo da temperatura de ebulição, como se pode verificar na tabela 04. Desta maneira, optouse pela primeira opção.

Tabela 04 - Temperaturas de ebulição dos solventes utilizados

\begin{tabular}{cc}
\hline Solvente & Temperatura de ebulição $\left({ }^{\circ} \mathrm{C}\right)$ \\
\hline tolueno & 110,60 \\
cicloexano & 80,7 \\
metil-etil-cetona & 79,6 \\
tetraidrofurano & 66,0 \\
1,4-dioxano & 101,2 \\
metanol & 64,5 \\
etanol & 78,24 \\
2-propanol & 82,21 \\
1-butanol & 117,6 \\
2-butanol & 99,4 \\
água & 100 \\
acetonitrila & 81,6 \\
acetona & 56,08
\end{tabular}

Fonte: CRC handbook of chemistry and physics - Online Version. 92. Cleveland, Ohio: CRC Press Online, 2011. (Adaptado)

Por fim, optou-se pela concentração mais baixa de ácido $\left(0,05 \mathrm{~mol} . \mathrm{L}^{-1}\right)$ em detrimento a intermediária, apesar de ambas fornecerem resultados similares. Esta escolha foi baseada em dois fatos, o primeiro é o menor uso de reagentes inorgânicos e o segundo é o fato da concentração inferior de ácido gerar uma diferenciação maior entre os pontos de etanol e de acetona (tanto em termos de lignina imiscível quanto de deslignificação). Assim, iniciou-se a realização das deslignificações com os demais solventes.

Os resultados das deslignificações organossolve para os diferentes solventes, com condições reacionais de $125^{\circ} \mathrm{C}, 60$ minutos de reação, concentração de ácido clorídrico de 0,05 mol. $\mathrm{L}^{-1}$, razão solvente principal/água de 9/1 e razão sólido/líquido igual a $1 / 10$, podem ser verificados na tabela 05 . Nesta tabela, pode-se verificar 0 conteúdo de lignina presente na matéria-prima utilizada, obtido pelos mesmos métodos descritos anteriormente. Os erros mostrados na tabela 05 são, na 
realidade, o desvio médio das amostras, visto que para as mesmas os testes de lignina foram realizados em duplicata, com exceção do teste para o bagaço integral que foi realizado cinco vezes.

Tabela 05 - Resultados das polpações organossolve para os solventes estudados, com 125ㄷ, 60 minutos de reação, concentração de $\mathrm{HCl}$ de $0,05 \mathrm{~mol} . \mathrm{L}-1$, razão solvente principal/água de 9/1 e razão sólido/líquido igual a 1/10.

\begin{tabular}{cccccc}
\hline $\begin{array}{c}\text { Solvente } \\
\text { principal }\end{array}$ & $\begin{array}{c}\text { Rendimento } \\
\mathbf{( \% )}\end{array}$ & $\begin{array}{c}\text { Lignina insolúvel } \\
\text { (\%) }\end{array}$ & $\begin{array}{c}\text { Lignina solúvel } \\
\mathbf{( \% )}\end{array}$ & $\begin{array}{c}\text { Lignina Total } \\
\mathbf{( \% )}\end{array}$ & $\begin{array}{c}\text { Deslignificação } \\
\text { (\%) }\end{array}$ \\
\hline Bagaço Integral & --- & $21,14 \pm 0,39$ & $1,08 \pm 0,17$ & $22,22 \pm 0,39$ & --- \\
etanol & 61,51 & $9,21 \pm 0,13$ & $0,30 \pm 0,05$ & $9,51 \pm 0,09$ & $73,68 \pm 0,24$ \\
1,4-dioxano & 49,48 & $4,86 \pm 0,25$ & $0,19 \pm 0,04$ & $5,05 \pm 0,21$ & $88,75 \pm 0,48$ \\
acetona & 59,23 & $12,09 \pm 0,05$ & $0,36 \pm 0,11$ & $12,44 \pm 0,06$ & $66,84 \pm 0,16$ \\
cicloexano & 70,49 & $17,91 \pm 0,24$ & $0,62 \pm 0,17$ & $18,53 \pm 0,07$ & $41,23 \pm 0,23$ \\
metanol & 62,07 & $9,94 \pm 0,06$ & $0,29 \pm 0,00$ & $10,22 \pm 0,06$ & $71,45 \pm 0,17$ \\
1-butanol & 55,93 & $8,54 \pm 0,13$ & $0,40 \pm 0,11$ & $8,94 \pm 0,24$ & $77,49 \pm 0,60$ \\
tetraidrofurano & 63,27 & $11,81 \pm 0,01$ & $0,54 \pm 0,02$ & $12,35 \pm 0,01$ & $64,85 \pm 0,03$ \\
isopropanol & 57,27 & $9,99 \pm 0,11$ & $0,51 \pm 0,01$ & $10,50 \pm 0,10$ & $72,95 \pm 0,25$ \\
2-butanol & 58,69 & $12,16 \pm 0,07$ & $0,52 \pm 0,05$ & $12,68 \pm 0,12$ & $66,50 \pm 0,31$ \\
metil-etil-cetona & 56,24 & $13,31 \pm 0,09$ & $0,65 \pm 0,25$ & $13,96 \pm 0,34$ & $64,68 \pm 0,86$ \\
tolueno & 71,14 & $18,37 \pm 0,23$ & $0,62 \pm 0,09$ & $19,00 \pm 0,32$ & $39,18 \pm 1,02$ \\
acetonitrila & 61,91 & $15,53 \pm 0,07$ & $0,32 \pm 0,06$ & $15,85 \pm 0,13$ & $55,85 \pm 0,38$ \\
água & 66,35 & $20,74 \pm 0,06$ & $0,50 \pm 0,08$ & $21,24 \pm 0,03$ & $36,58 \pm 0,08$ \\
\hline
\end{tabular}

Pode-se observar que os desvios padrão das análises não é elevado, inferior à $5 \%$, indicando a presença de poucos erros aleatórios. Especificamente, para as análises de lignina Klason, é interessante observar os erros, visto que este método foi modificado. Para esta análise, deve-se observar o valor da amostra de bagaço integral, que foi a amostra com maior número de análises, 5 , enquanto que as demais amostras foram feitas em duplicata. Pode-se verificar que o desvio entre as amostras não foi grande, correspondendo a uma variação de menos de $2 \% \mathrm{com}$ relação ao valor obtido de lignina Klason. Comparativamente, os valores de lignina obtidos por este método, para a matéria-prima, são muito similares aos resultados obtidos pelo método Klason padrão $(21,91 \%$ de lignina imiscível, $0,78 \%$ de lignina miscível e $22,69 \%$ de lignina total (MARABEZI, 2009)), sendo que pequenas 
diferenças podem ocorrer, visto que são amostras de diferentes safras. Portanto, pode-se concluir que a modificação do método não ofereceu diferenças significativas ao resultado obtido. Desta maneira, conclui-se que o método utilizado é confiável.

Em comparação com os resultados obtidos por Balogh et al. (1992), tabela 06, que utilizou como matéria-prima serragem de Pinus caribaea hondurensis, com condições reacionais iguais a razão sólido/liquido igual a 1/8, razão de solvente orgânico/água igual a 9/1, temperatura igual a $125^{\circ} \mathrm{C}$, concentração final de ácido clorídrico igual a 0,2 mol. $\mathrm{L}^{-1}$ e tempo igual a 6 horas, os valores de deslignificação obtidos para as reações com bagaço de cana-de-açúcar foram muito maiores, apesar do uso de uma razão sólido/líquido, tempo e concentração de ácido menores. Isto indica que para a reação de deslignificação de bagaço de cana-deaçúcar a remoção de lignina é muito mais facilitada, visto que o bagaço é uma matéria-prima menos lignificada e mais fácil de absorver líquidos (Nada e Sefain, 1986), sendo assim mais acessível ao licor de polpação, o que promove uma deslignificação mais expressiva para o bagaço de cana-de-açúcar. Este fato também pode ser visto em outros trabalhos na literatura (PASQUINI et al., 2005).

Tabela 06 - Resultados de deslignificação para serragem de Pinus caribaea hondurensis.

\begin{tabular}{cc}
\hline Solvente & Deslignificação (\%) \\
\hline clorofórmio & 3,57 \\
acetona & 25,93 \\
1,4-dioxane & 78,27 \\
tetraidrofurano & 26,37 \\
2-butanol & 25,83 \\
1-butanol & 81,47 \\
1-propanol & 43,40 \\
etanol & 39,13 \\
metanol & 30,30
\end{tabular}

Fonte: BALOGH, D. T.; CURVELO, A. A. S.; DE GROOTE, R. A. M. C. Solvent Effects on Organosolv Lignin from Pinus caribaea hondurensis. Holzforschung, v. 46, n. 4, p.343-348, 1992. (Adaptado)

Diferentemente dos resultados obtidos por Balogh et al. (1992), o solvente que promoveu a melhor deslignificação nas condições estudas foi o 1,4-dioxano, com $88,75 \%$ de deslignificação, em comparação com o valor de $81,47 \%$ para a deslignificação de $P$. caribaea com 1-butanol, contudo, em ambos observa-se que os 
dois melhores solventes para a deslignificação organossolve são o 1,4-dioxano e o 1-butanol.

Comparando-se os resultados das tabelas 05 e 06, observa-se que os resultados estão relacionados. Observa-se que para Balogh et al. (1992) o valor de deslignificação para os solventes tetraidrofurano, acetona e 2-butanol (solventes que constam em ambos os trabalhos com os menores valores de deslignificação) são muito próximos, da mesma maneira que os resultados obtidos nas deslignificações com bagaço de cana. Estes resultados indicam que uma metodologia similar à utilizada por Balogh et al. (1992) de utilização de parâmetros de solubilidade pode ser aplicada a este trabalho.

\subsection{PARÂMETROS DE SOLUBILIDADE PARA LIGNINA DE BAGAC̣O}

Baseando-se no trabalho desenvolvido por Balogh et al. (1992), construiu-se uma curva relacionando os parâmetros de solubilidade de Hildebrand para os solventes, ou misturas de solvente (para os casos que o solvente é miscível com a água), com os valores de deslignificação. Na figura 29 pode-se observar esta curva.

Figura 29 - Dados de deslignificação versus parâmetros de solubilidade de Hildebrand.

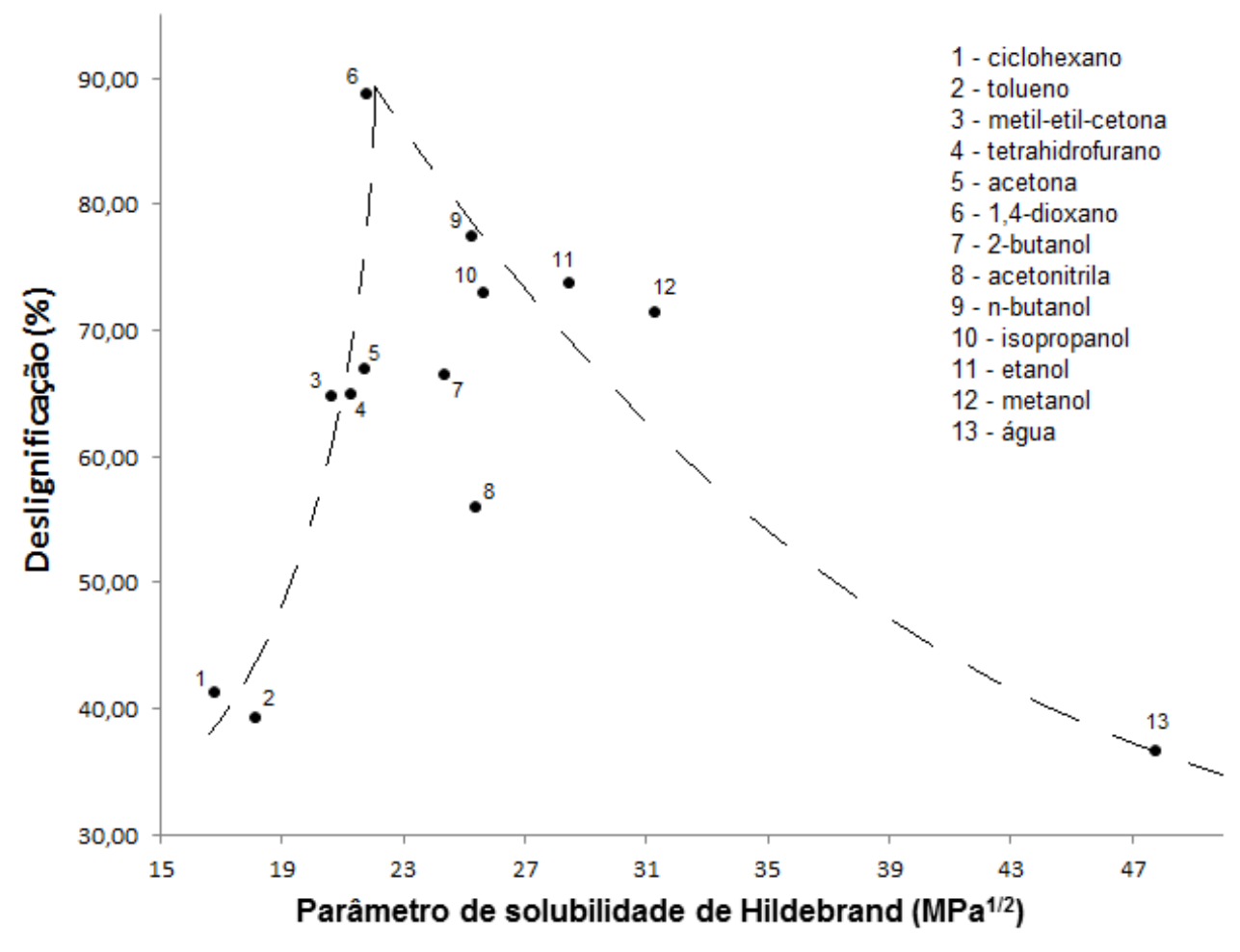


Pode-se observar na figura 29 que o ajuste dos dados de deslignificação com os parâmetros de solubilidade de Hildebrand para os diferentes solventes e misturas de solventes é inadequado. Verifica-se que para alguns solventes o parâmetro de solubilidade de Hildebrand se relaciona com os valores de deslignificação, porém observa-se que para alguns, pontos 7 e 8 , o mesmo não ocorre. Isto pode ser explicado pela diferença entre os tipos de interações que ocorrem em cada solvente e/ou pelo tamanho dos mesmos, ou seja, as misturas de solventes 1-butanol/água e acetonitrila/água possuem praticamente o mesmo parâmetro de Hildebrand porém apresentam uma diferença de deslignificação muito acentuada, enquanto o primeiro pode ser considerado um bom solvente para a solubilização da lignina, o segundo se mostra um solvente ruim, assim, observando-se os parâmetros de solubilidade de Hansen presentes na tabela 02 para estas mesmas misturas verifica-se que há uma inversão entre os valores de $\delta_{d}$ e $\delta_{h}$, enquanto o n-butanol possui um valor de $\delta_{d}$ relativamente pequeno e um $\delta_{h}$ mais elevado a acetonitrila possui o inverso, $\delta_{d}$ mais elevado e um $\delta_{h}$ relativamente pequeno. A lignina possui diversos grupos hidroxila que podem realizar ligações de hidrogênio, apesar de apresentar um caráter mais apolar do que polar, assim, o solvente n-butanol se apresenta como um solvente com mais características similares às das ligninas. Desta maneira, verifica-se que uma descrição utilizando os parâmetros de solubilidade de Hansen poderia ser mais adequada para tentar se estabelecer a relação com a deslignificação.

Diferentemente do caso da acetonitrila, a análise com relação ao comportamento do 2-butanol deve ser diferenciada. Comparativamente, o 1-butanol e o 2-butanol possuem características muito similares, como se pode observar pelos valores de parâmetro de solubilidade de Hansen na tabela 02. Contudo, apesar do 2-butanol estar sendo mostrado como formando uma solução com a água isto não ocorre a temperatura ambiente, porém como após a separação do licor de polpação da polpa lignocelulósica o licor se apresentou como somente uma fase líquida (a temperatura de reação ambos devem ser minimamente solúveis entre si), considerou-se que este também poderia ser solúvel em água. Desta maneira, duas hipóteses puderam ser levantadas para se explicar a diferença entre os valores de deslignificação do 2-butanol e do 1-butanol. A primeira é a dificuldade da solubilização do 2-butanol com a água, assim, os parâmetros de solubilidade do 2butanol e do 1-butanol se apresentariam com uma diferença maior entre si, podendo se localizar um fora da esfera da lignina e o outro dentro. Já a segunda hipótese, é 
uma consideração relacionada à cinética da reação. A diferença dos volumes moleculares poderia influenciar na capacidade de cada solvente de atuar como solvente.

Com relação à segunda hipótese, uma maneira de validá-la ou invalidá-la seria verificar os volumes moleculares, ou volume de Van der Waals, e compará-los. Assim, verificou-se que os mesmos correspondem a 85-87 e 83-87 $\AA^{3} /$ molécula, para o n-butanol e para o 2-butanol, respectivamente (BONDI, 1964; ZHAO et al., 2003). Verifica-se que a diferença entre os volumes de Van der Waals é muito pequena, não permitindo uma diferenciação entre os mesmos. Portanto, a segunda hipótese pode ser refutada, enquanto a primeira hipótese é reforçada.

Utilizando-se os parâmetros de solubilidade de Hansen para a lignina, obtidos na literatura, figura 23 (HANSEN; BJORKMAN, 1998) e as equações 11 e 12, construiu-se gráficos relacionando $R_{a}$ e $R E D$ dos solventes, considerando duas possibilidades para a miscibilidade do 2-butanol (miscível ou imiscível), com os valores de deslignificação. Nas figuras 30 e 31 pode-se verificar estes gráficos. Verifica-se, que para os parâmetros de solubilidade de Hansen para a lignina encontrados na literatura, o ponto referente ao solvente 2-butanol está um pouco melhor posicionado no caso de insolubilidade em água, visto pelo valor de " $\mathrm{R}^{2 \text { " }}$ ligeiramente superior. Contudo, observa-se também que a descrição da relação entre a deslignificação e os valores de $R_{a}$ e $R E D$ não é eficaz, pois para um mesmo valor de $R_{a}$ ou de $R E D$ específico há mais de uma mesma resposta, com valor de deslignificação muito diferenciado (concentração dos dados em uma mesma área do gráfico), por exemplo, para um valor de $R_{a}$ igual a aproximadamente $14 \mathrm{MPa}^{1 / 2}$ existem valores de deslignificação variando entre aproximadamente 65 e 90\%. Apesar disto, observa-se que todos os pontos experimentais podem ser descritos pelos modelos desenvolvidos, com um nível de confiança de $95 \%$, visto que todos estão entre as curvas de predição de nível de confiança de 95\%, curvas azuis.

$\mathrm{Na}$ figura 31, observa-se que para ambos os casos (2-butanol miscível ou imiscível em água) todos os solventes utilizados estão localizados fora da esfera que indica a solubilidade da lignina $(R E D \leq 1,0 \rightarrow$ dentro da esfera; $R E D>1,0 \rightarrow$ fora da esfera), mesmo considerando-se os solventes puros, com exceção do etanol, o que indicaria que nenhum solvente ou mistura de solvente seria bom para a solubilização da lignina, como se pode observar na tabela 07. Assim, verifica-se a necessidade da obtenção de parâmetros de solubilidade específicos para lignina de cana-de-açúcar 
e que sejam mais apropriados para descrever a deslignificação organossolve nas condições estudadas.

Figura 30 - Gráfico de $R_{a}$ para os diferentes solventes utilizados versus deslignificação: a) 2-butanol imiscível em água; e b) 2-butanol miscível em água.
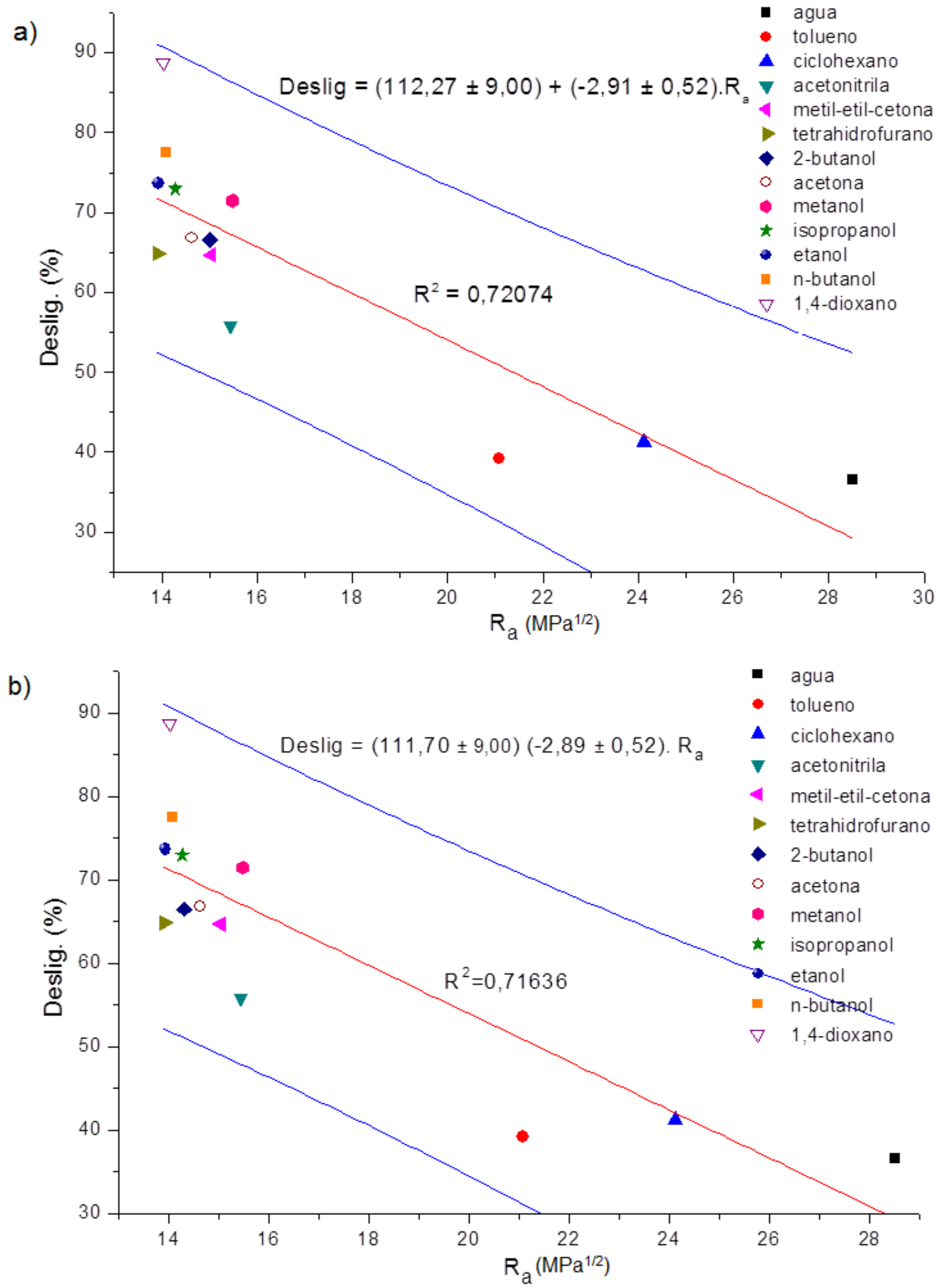
Figura 31 - Gráfico de RED para os diferentes solventes versus deslignificação: a) 2-butanol imiscível em água; e b) 2-butanol miscível em água.

a)

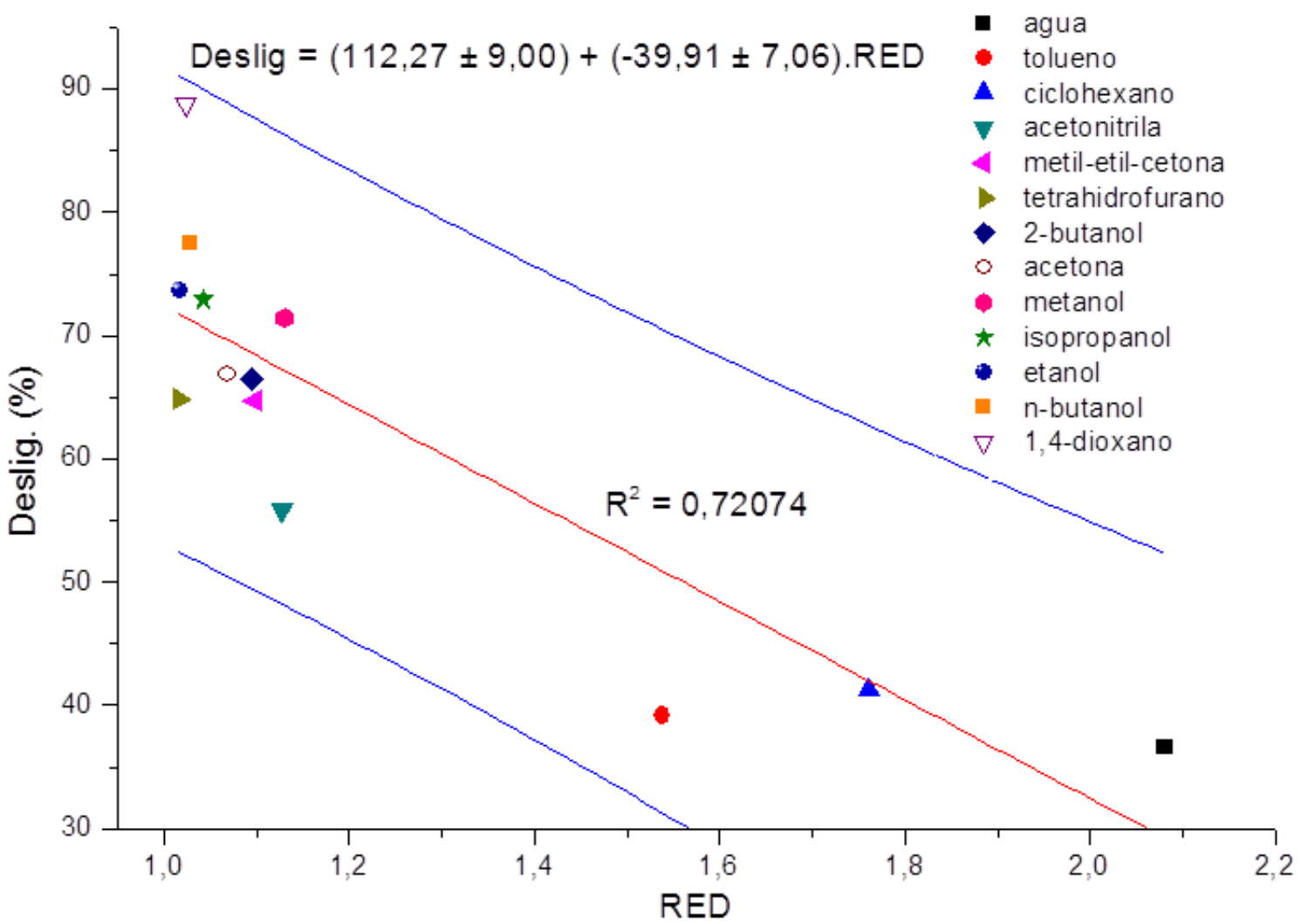

b)

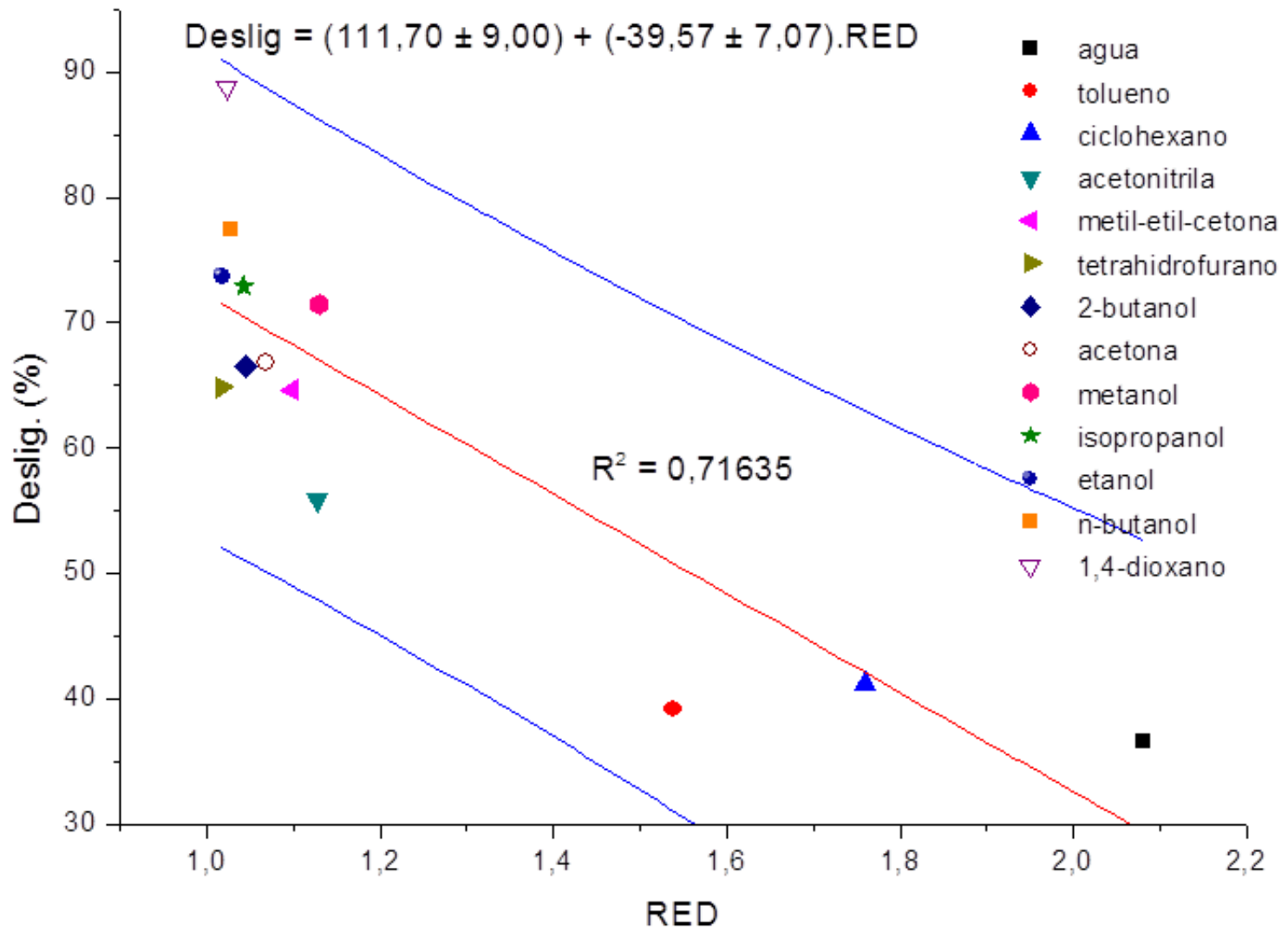


Tabela 07 - Valores de $R_{a}$ e RED para os solventes utilizados puros e com 10\% de água.

\begin{tabular}{ccccc}
\hline & \multicolumn{3}{c}{ Solventes Puros } & \multicolumn{2}{c}{ Solventes com 10\% de água } \\
Solvente principal & $\boldsymbol{R}_{\boldsymbol{a}}$ & $\boldsymbol{R} \boldsymbol{E} \boldsymbol{D}$ & $\boldsymbol{R}_{\boldsymbol{a}}$ & $\boldsymbol{R} \boldsymbol{E} \boldsymbol{D}$ \\
\hline tolueno & 21,07 & 1,54 & --- & --- \\
cicloexano & 24,12 & 1,76 & --- & --- \\
metil-etil-cetona & 17,45 & 1,27 & 15,04 & 1,10 \\
tetraidrofurano & 15,93 & 1,16 & 13,92 & 1,02 \\
1,4-dioxano & 16,59 & 1,21 & 14,03 & 1,02 \\
metanol & 14,74 & 1,08 & 15,48 & 1,13 \\
etanol & 13,53 & 0,99 & 13,94 & 1,02 \\
isopropanol & 14,60 & 1,07 & 14,28 & 1,04 \\
1-butanol & 14,53 & 1,06 & 14,08 & 1,03 \\
2-butanol & 15,01 & 1,10 & 14,31 & 1,04 \\
água & 28,51 & 2,08 & --- & --- \\
acetonitrila & 17,50 & 1,28 & 15,44 & 1,13 \\
acetona & 16,60 & 1,21 & 14,63 & 1,07 \\
\hline
\end{tabular}

4.2.1 OBTENÇÃo dos PARÂMETROS DE SOLUBILIDADE DE HANSEN PARA A LIGNINA DE CANA-DE-AÇÚCAR

Para a obtenção dos parâmetros de solubilidade de Hansen da lignina que descrevam a relação entre a deslignificação e os parâmetros de solubilidade dos solventes orgânicos realizou-se as diversas corridas no programa MatLab, considerando-se as diferentes deslignificações mínimas, no programa feito para a obtenção de parâmetros de solubilidade para polímeros, utilizando bancos de dados de parâmetros de solubilidade dos solventes e a solubilidade da lignina nos mesmos (valores "0" ou "1,0") Nas tabelas 08 e 09 pode-se observar os valores dos bancos de dados desenvolvidos para as corridas, considerando os casos da imiscibilidade e miscibilidade do 2-butanol em água, respectivamente. Os dados gerados pelo programa são dispostos conforme mostrado na figura 32 , indicando os valores dos parâmetros de solubilidade, o valor de solubilidade inserido no programa, o valor de $R E D$ para os parâmetros de solubilidade gerados para o polímero, o valor de "Data 
Fit" (função de desejabilidade, que indica a qualidade do ajuste dos dados, sendo o valor 1,0 o maior ajuste e 0 o menor) e, finalmente, os parâmetros de solubilidade para o polímero, incluindo o valor de $R_{0}$.

Tabela 08 - Dados de solubilidade inseridos no programa para diferentes porcentagens de deslignificação mínima e parâmetros de solubilidade da literatura e gerados para lignina, considerando o 2-butanol como imiscível em água.

\section{Solvente principal}

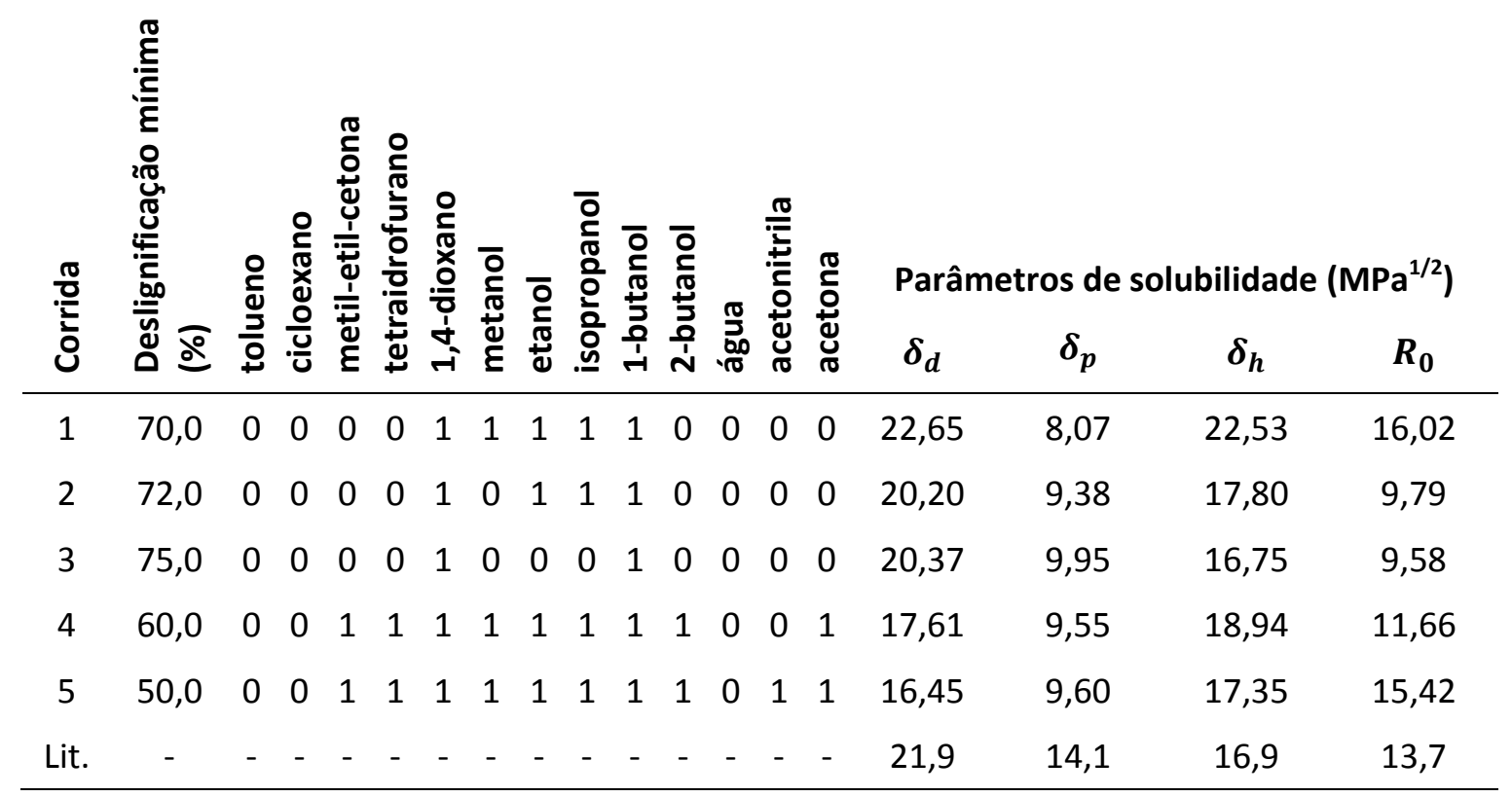

Tabela 09 - Dados de solubilidade inseridos no programa para diferentes porcentagens de deslignificação mínima e parâmetros de solubilidade gerados para lignina, considerando o 2-butanol como miscível em água.

Solvente principal

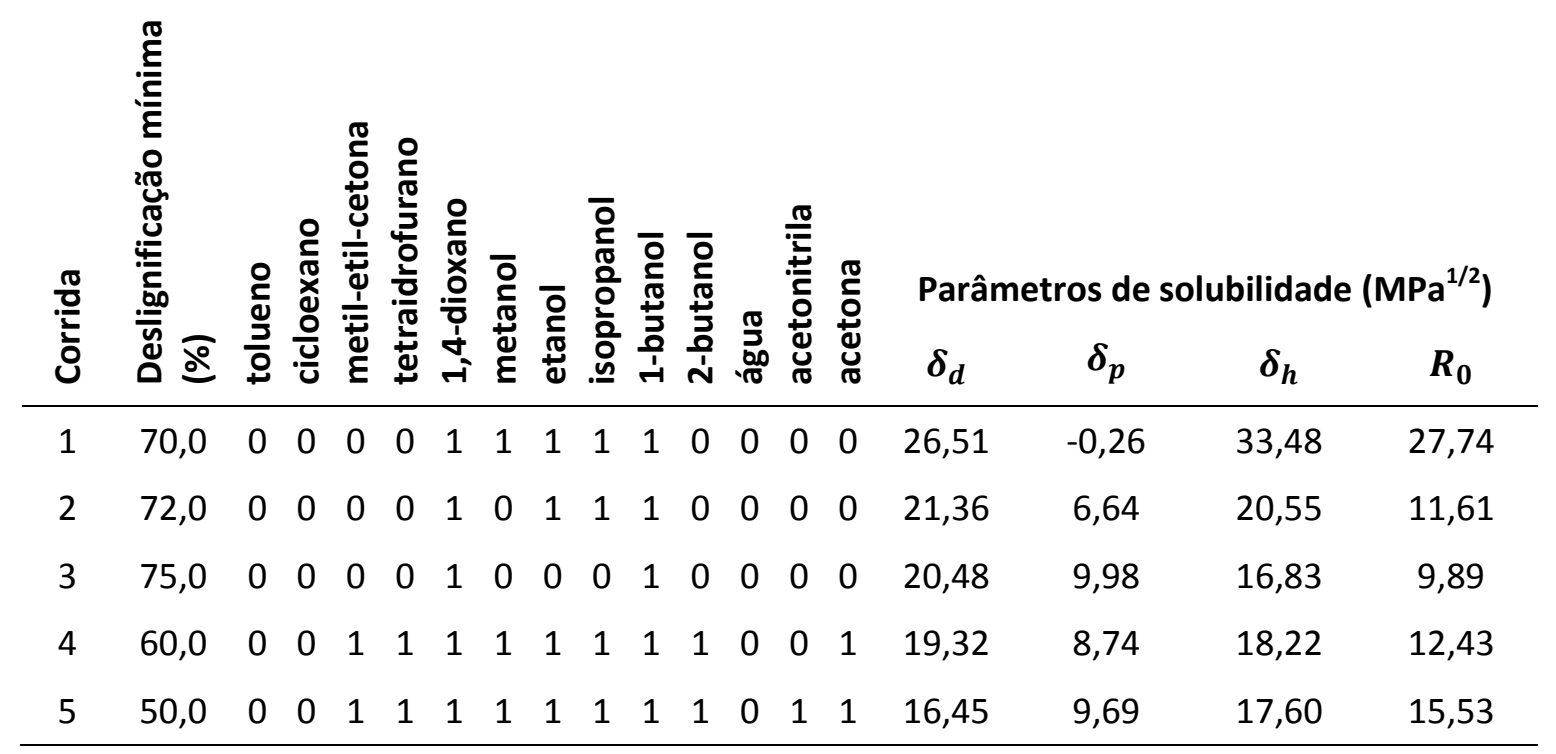


Figura 32 - Modelo do programa para gerar parâmetros de solubilidade para polímeros.

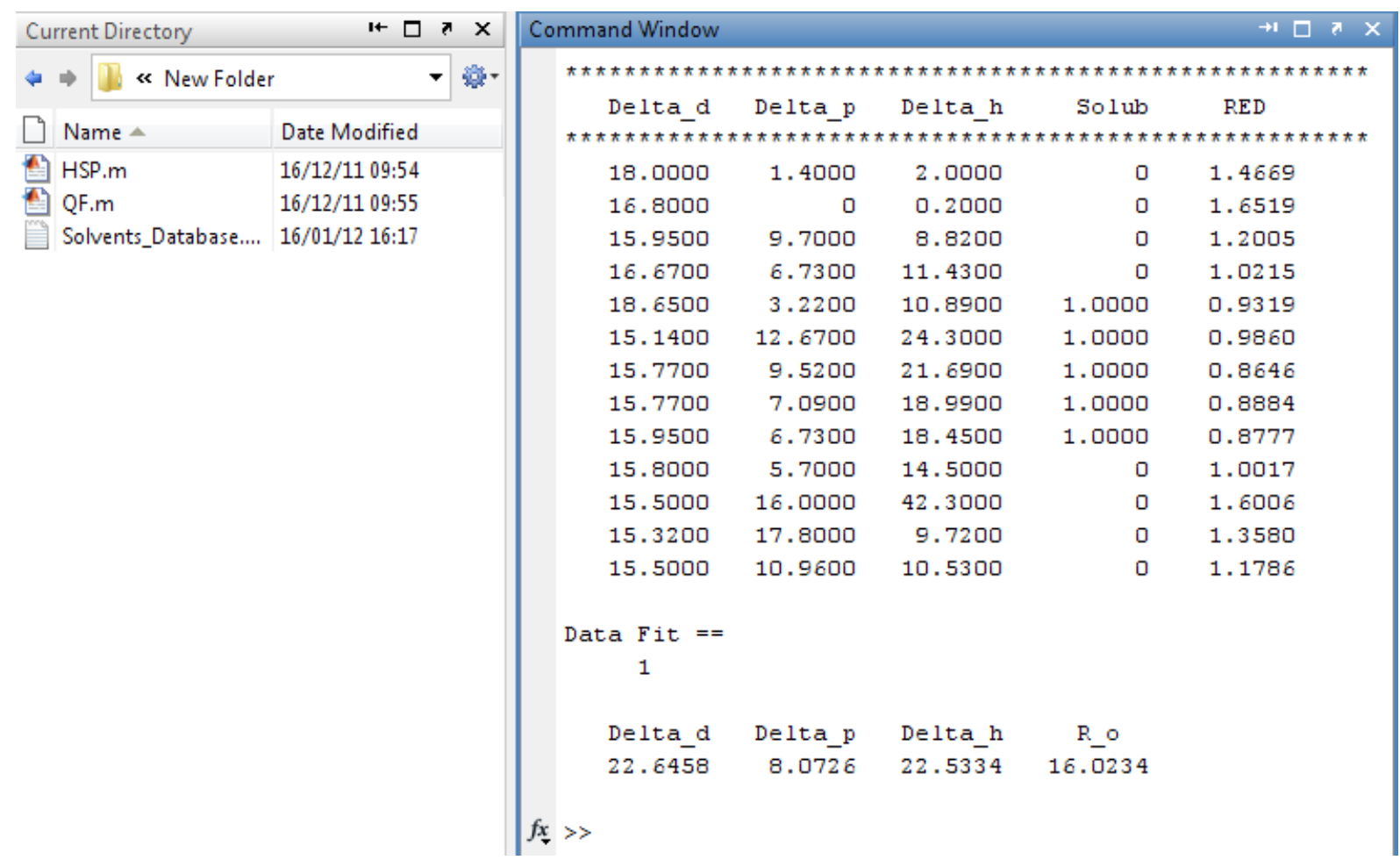

Após a geração dos arquivos "HSP.m", "QF.m" e "Solvents_Database.txt", código descrito no anexo 1 , em um mesmo diretório, para a realização de uma corrida pelo programa, deve-se escrever "HSP" na janela de comandos (no local indicado por " $f x \gg$ 》), após o período de processamento de dados, observa-se uma tela similar a mostrada na figura 32 .

O programa se utiliza de 5 parâmetros estabelecidos pelo usuário para o cálculo dos parâmetros de solubilidade do polímero: $\delta_{d}(i)$ (parâmetro de solubilidade para interações do tipo dispersivas para um dado solvente, primeira coluna do banco de dados "Solvents_Database.txt"); $\delta_{p}(i)$ (parâmetro de solubilidade para interações polares para um dado solvente, segunda coluna do banco de dados "Solvents_Database.txt"); $\delta_{h}(i)$ (parâmetro de solubilidade para ligações de hidrogênio para um dado solvente, terceira coluna do banco de dados "Solvents_Database.txt"); n (estabelecido como sendo o número de solventes, logo após a importação do banco de dados no programa "HSP.m"); e a solubilidade do polímero em um dado solvente (valor igual a 0 para insolúvel e igual a 1,0 para solúvel, quarta coluna do banco de dados "Solvents_Database.txt"). O algoritmo utilizado no programa também pode ser observado no anexo 1.

Com os parâmetros de solubilidade gerados para a lignina, obteve-se as distancias entre os solventes e o centro da esfera de solubilidade da lignina, $R_{a}$, e a 
afinidade entre o solvente e a lignina, $R E D$, utilizando as equações 11 e 12 , respectivamente. As tabelas 10 e 11 mostram os valores de $R_{a}$ e $R E D$ para cada corrida e cada solvente, tanto para o caso do 2-butanol sendo imiscível em água quanto para o caso deste ser miscível, respectivamente.

Tabela 10 - Distâncias e afinidades com as ligninas das corridas, considerando o 2-butanol como imiscível em água.

\begin{tabular}{ccccccccccc}
\hline Solvente & \multicolumn{3}{c}{ Corrida 1 } & \multicolumn{3}{c}{ Corrida 2 } & \multicolumn{3}{c}{ Corrida 3 } & \multicolumn{2}{c}{ Corrida 4 } & \multicolumn{2}{c}{ Corrida 5 } \\
principal & $\boldsymbol{R}_{\boldsymbol{a}}$ & $\boldsymbol{R} \boldsymbol{E} \boldsymbol{D}$ & $\boldsymbol{R}_{\boldsymbol{a}}$ & $\boldsymbol{R} \boldsymbol{E} \boldsymbol{D}$ & $\boldsymbol{R}_{\boldsymbol{a}}$ & $\boldsymbol{R} \boldsymbol{E} \boldsymbol{D}$ & $\boldsymbol{R}_{\boldsymbol{a}}$ & $\boldsymbol{R} \boldsymbol{E} \boldsymbol{D}$ & $\boldsymbol{R}_{\boldsymbol{a}}$ & $\boldsymbol{R} \boldsymbol{E} \boldsymbol{D}$ \\
\hline tolueno & 23,50 & 1,47 & 18,24 & 1,86 & 17,69 & 1,85 & 18,81 & 1,61 & 17,68 & 1,15 \\
cicloexano & 26,47 & 1,65 & 21,07 & 2,15 & 20,58 & 2,15 & 21,09 & 1,81 & 19,67 & 1,28 \\
metil-etil-cetona & 19,24 & 1,20 & 12,37 & 1,26 & 11,87 & 1,24 & 10,65 & 0,91 & 8,59 & 0,56 \\
tetraidrofurano & 16,37 & 1,02 & 9,87 & 1,01 & 9,66 & 1,01 & 8,24 & 0,71 & 6,60 & 0,43 \\
1,4-dioxano & 14,93 & 0,93 & 9,76 & 1,00 & 9,56 & 1,00 & 10,45 & 0,90 & 10,09 & 0,65 \\
metanol & 15,80 & 0,99 & 12,47 & 1,27 & 13,18 & 1,38 & 7,93 & 0,68 & 8,03 & 0,52 \\
etanol & 13,85 & 0,86 & 9,68 & 0,99 & 10,45 & 1,09 & 4,59 & 0,39 & 4,55 & 0,29 \\
isopropanol & 14,23 & 0,89 & 9,23 & 0,94 & 9,89 & 1,03 & 4,42 & 0,38 & 3,29 & 0,21 \\
1-butanol & 14,06 & 0,88 & 8,92 & 0,91 & 9,55 & 1,00 & 4,38 & 0,38 & 3,23 & 0,21 \\
2-butanol & 16,05 & 1,00 & 10,09 & 1,03 & 10,32 & 1,08 & 6,90 & 0,59 & 5,01 & 0,32 \\
água & 25,65 & 1,60 & 27,06 & 2,76 & 28,01 & 2,92 & 24,60 & 2,11 & 25,82 & 1,67 \\
acetonitrila & 21,76 & 1,36 & 15,21 & 1,55 & 14,59 & 1,52 & 13,19 & 1,13 & 11,43 & 0,74 \\
acetona & 18,88 & 1,18 & 11,98 & 1,22 & 11,58 & 1,21 & 9,50 & 0,81 & 7,21 & 0,47 \\
\hline
\end{tabular}

Tabela 11 - Distâncias e afinidades com as ligninas das corridas, considerando o 2-butanol como miscível em água.

\begin{tabular}{ccccccccccc}
\hline Solvente & \multicolumn{1}{c}{ Corrida 1 } & \multicolumn{2}{c}{ Corrida 2 } & \multicolumn{2}{c}{ Corrida 3 } & \multicolumn{2}{c}{ Corrida 4 } & \multicolumn{2}{c}{ Corrida 5 } \\
principal & $\boldsymbol{R}_{\boldsymbol{a}}$ & $\boldsymbol{R} \boldsymbol{E} \boldsymbol{D}$ & $\boldsymbol{R}_{\boldsymbol{a}}$ & $\boldsymbol{R} \boldsymbol{E} \boldsymbol{D}$ & $\boldsymbol{R}_{\boldsymbol{a}}$ & $\boldsymbol{R} \boldsymbol{E} \boldsymbol{D}$ & $\boldsymbol{R}_{\boldsymbol{a}}$ & $\boldsymbol{R} \boldsymbol{E} \boldsymbol{D}$ & $\boldsymbol{R}_{\boldsymbol{a}}$ & $\boldsymbol{R} \boldsymbol{E} \boldsymbol{D}$ \\
\hline tolueno & 35,83 & 1,29 & 20,41 & 1,76 & 17,84 & 1,80 & 18,00 & 1,45 & 17,94 & 1,16 \\
cicloexano & 38,53 & 1,39 & 23,26 & 2,00 & 20,75 & 2,10 & 20,65 & 1,66 & 19,93 & 1,28 \\
metil-etil-cetona & 33,96 & 1,22 & 16,25 & 1,40 & 12,10 & 1,22 & 11,60 & 0,93 & 8,84 & 0,57 \\
tetraidrofurano & 30,37 & 1,09 & 13,08 & 1,13 & 9,89 & 1,00 & 8,84 & 0,71 & 6,86 & 0,44 \\
1,4-dioxano & 27,74 & 1,00 & 11,59 & 1,00 & 9,72 & 0,98 & 9,27 & 0,75 & 10,31 & 0,66 \\
metanol & 27,73 & 1,00 & 14,32 & 1,23 & 13,31 & 1,35 & 11,06 & 0,89 & 7,78 & 0,50 \\
etanol & 26,39 & 0,95 & 11,60 & 1,00 & 10,61 & 1,07 & 7,94 & 0,64 & 4,31 & 0,28 \\
isopropanol & 26,94 & 0,97 & 11,30 & 0,97 & 10,09 & 1,02 & 7,33 & 0,59 & 3,25 & 0,21 \\
1-butanol & 26,85 & 0,97 & 11,02 & 0,95 & 9,76 & 0,99 & 7,03 & 0,57 & 3,24 & 0,21 \\
2-butanol & 27,80 & 1,00 & 11,65 & 1,00 & 9,98 & 1,01 & 7,43 & 0,60 & 3,27 & 0,21 \\
água & 28,76 & 1,04 & 26,42 & 2,28 & 28,00 & 2,83 & 26,28 & 2,11 & 25,56 & 1,65 \\
acetonitrila & 37,31 & 1,34 & 19,69 & 1,70 & 14,78 & 1,49 & 14,77 & 1,19 & 11,53 & 0,74 \\
acetona & 33,72 & 1,22 & 16,00 & 1,38 & 11,82 & 1,20 & 11,05 & 0,89 & 7,42 & 0,48 \\
\hline
\end{tabular}


Com os valores obtidos de $R_{a}$ e $R E D$, construiu-se gráficos relacionando-os às porcentagens de deslignificação obtidas pelos diferentes sistemas de solventes. Nas figuras 33 a 42 pode-se observar estes gráficos.

Figura 33 - Gráfico de $R_{a}$ para os parâmetros de solubilidade da corrida 1 versus deslignificação para: a) 2-butanol imiscível em água; e b) 2-butanol miscível em água.

a)

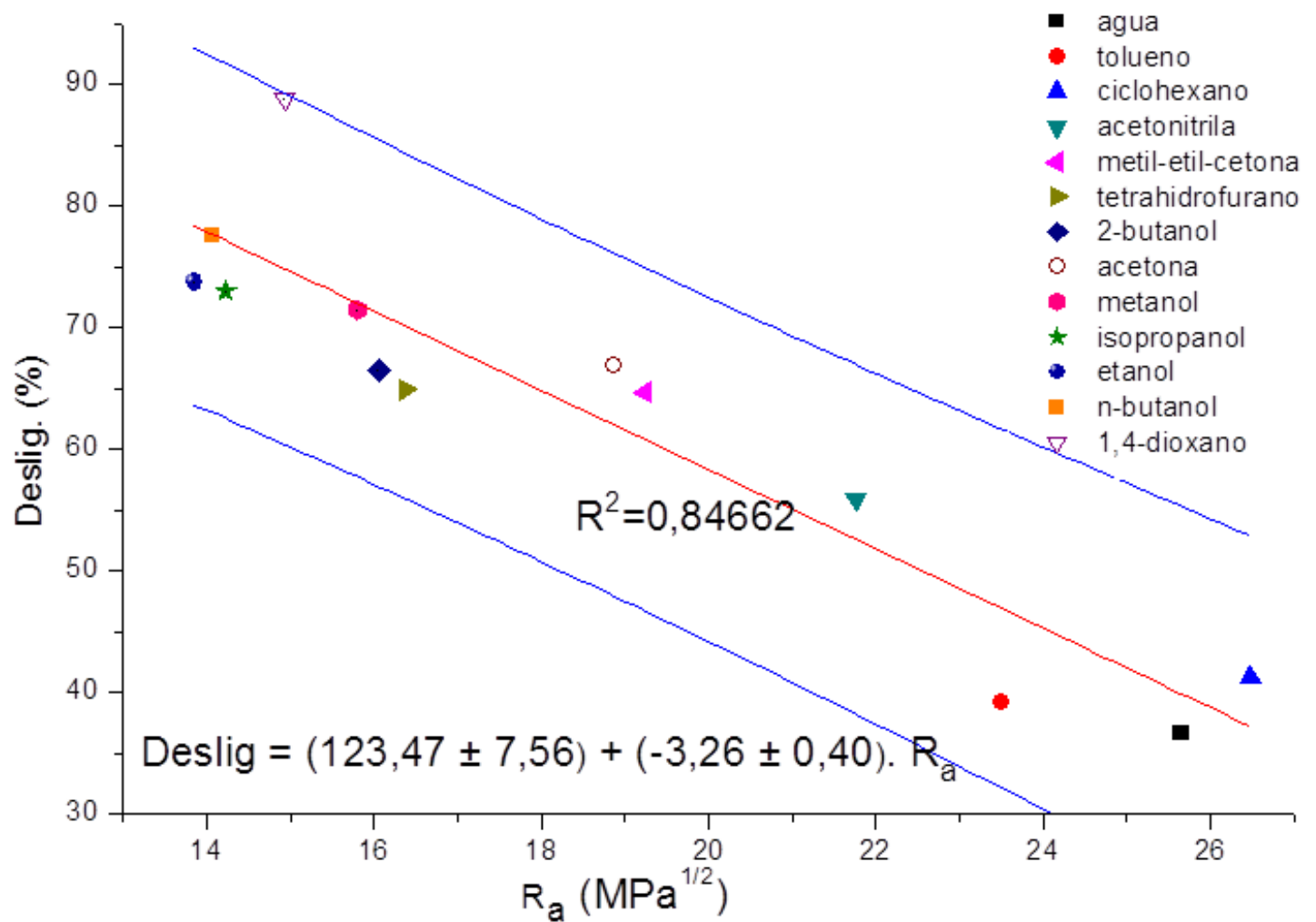

b)

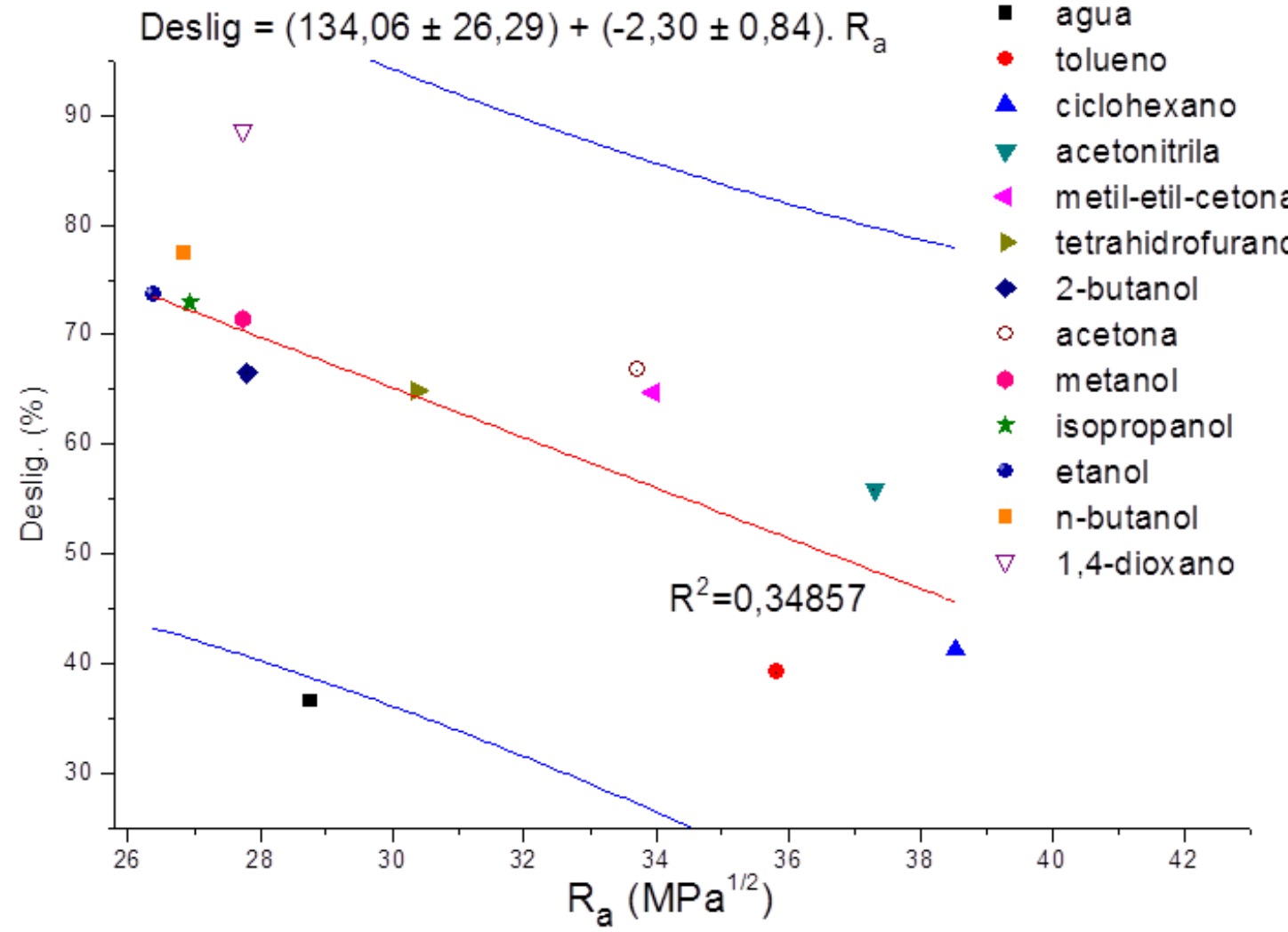


Figura 34 - Gráfico de RED para os parâmetros de solubilidade da corrida 1 versus deslignificação para: a) 2-butanol imiscível em água; e b) 2-butanol miscível em água.

a)

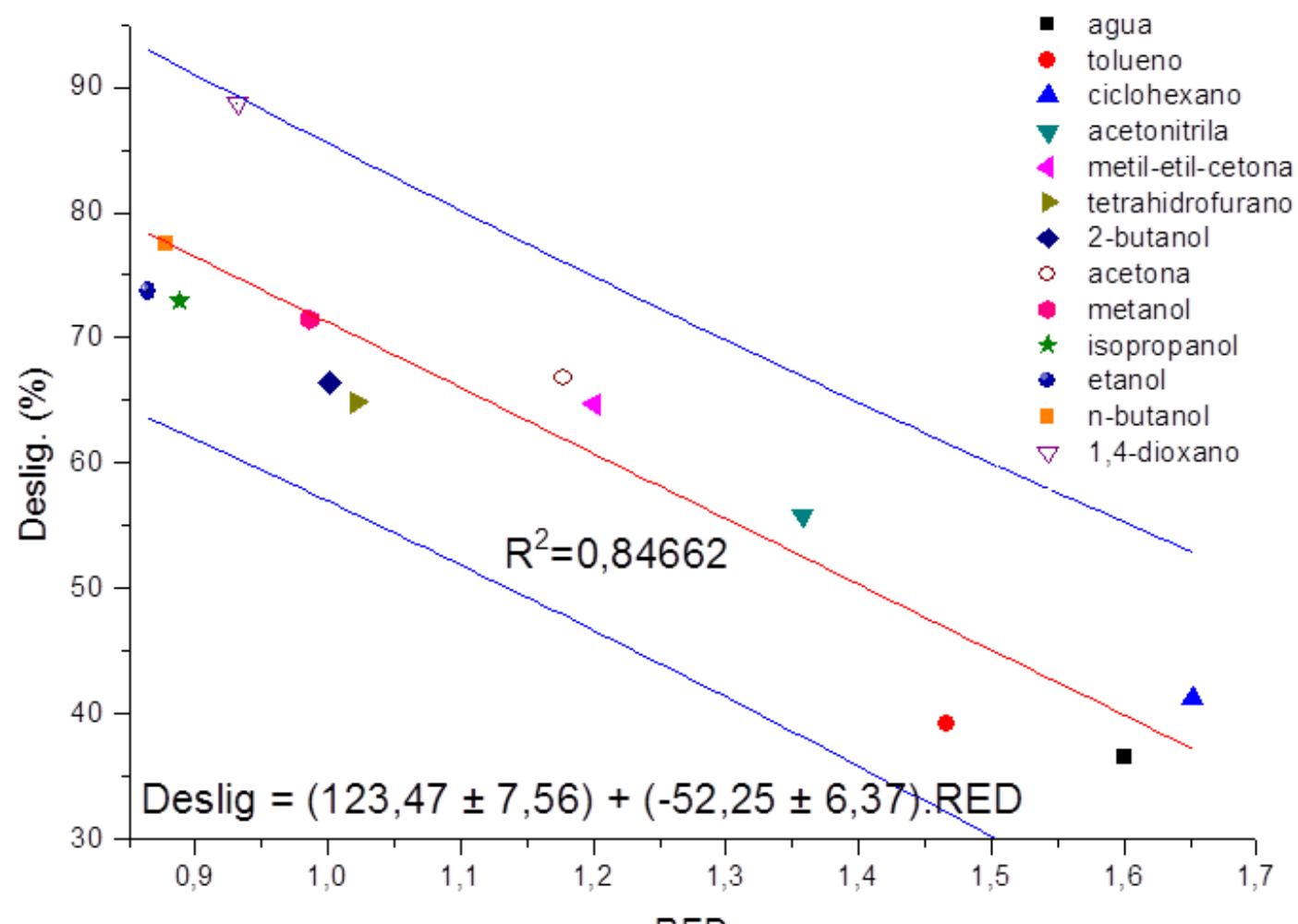

b)

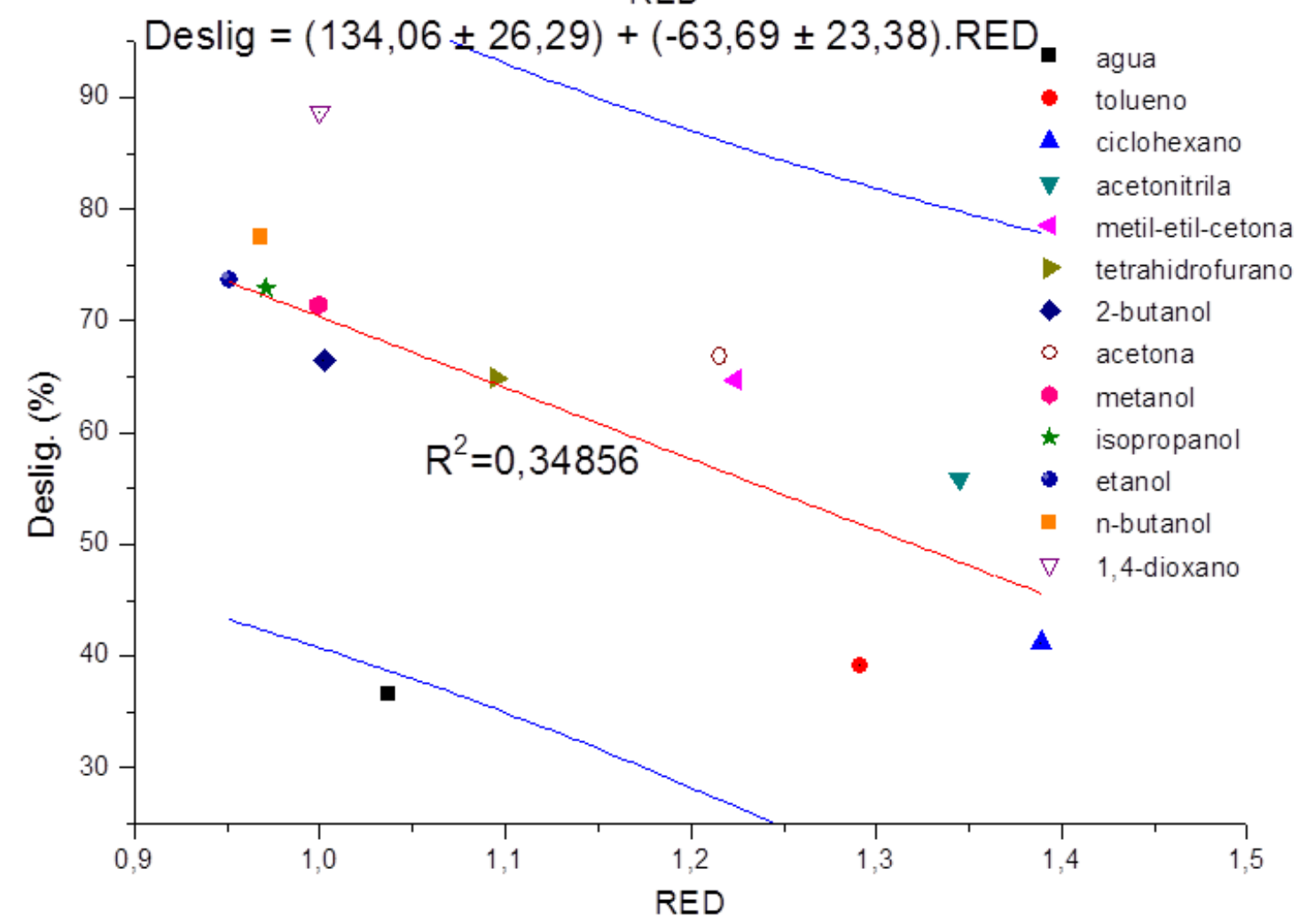


Figura 35 - Gráfico de $R_{a}$ para os parâmetros de solubilidade da corrida 2 versus deslignificação para: a) 2-butanol imiscível em água; e b) 2-butanol miscível em água.

a)

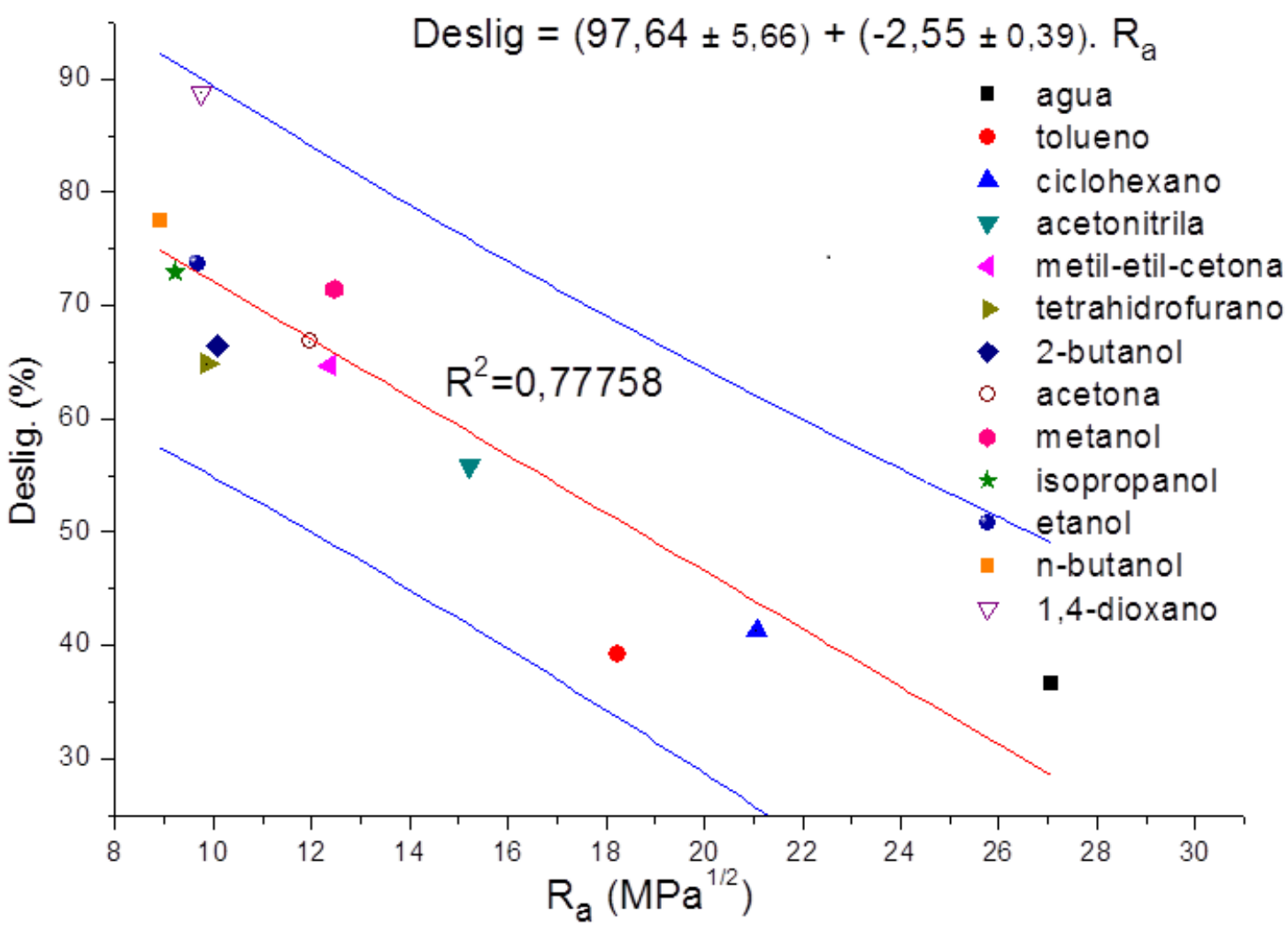

b)

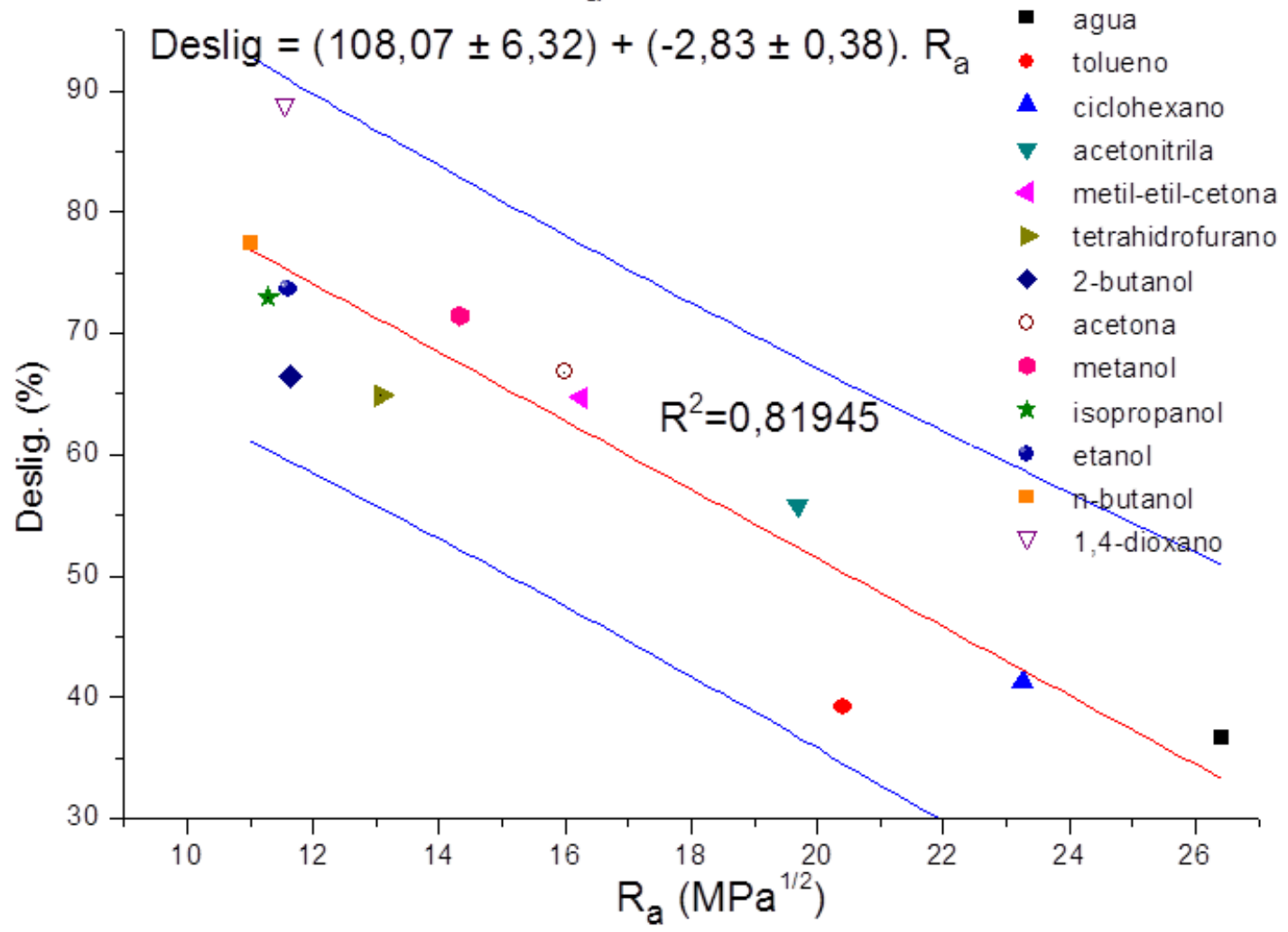


Figura 36 - Gráfico de RED para os parâmetros de solubilidade da corrida 2 versus deslignificação para: a) 2-butanol imiscível em água; e b) 2-butanol miscível em água.

a)

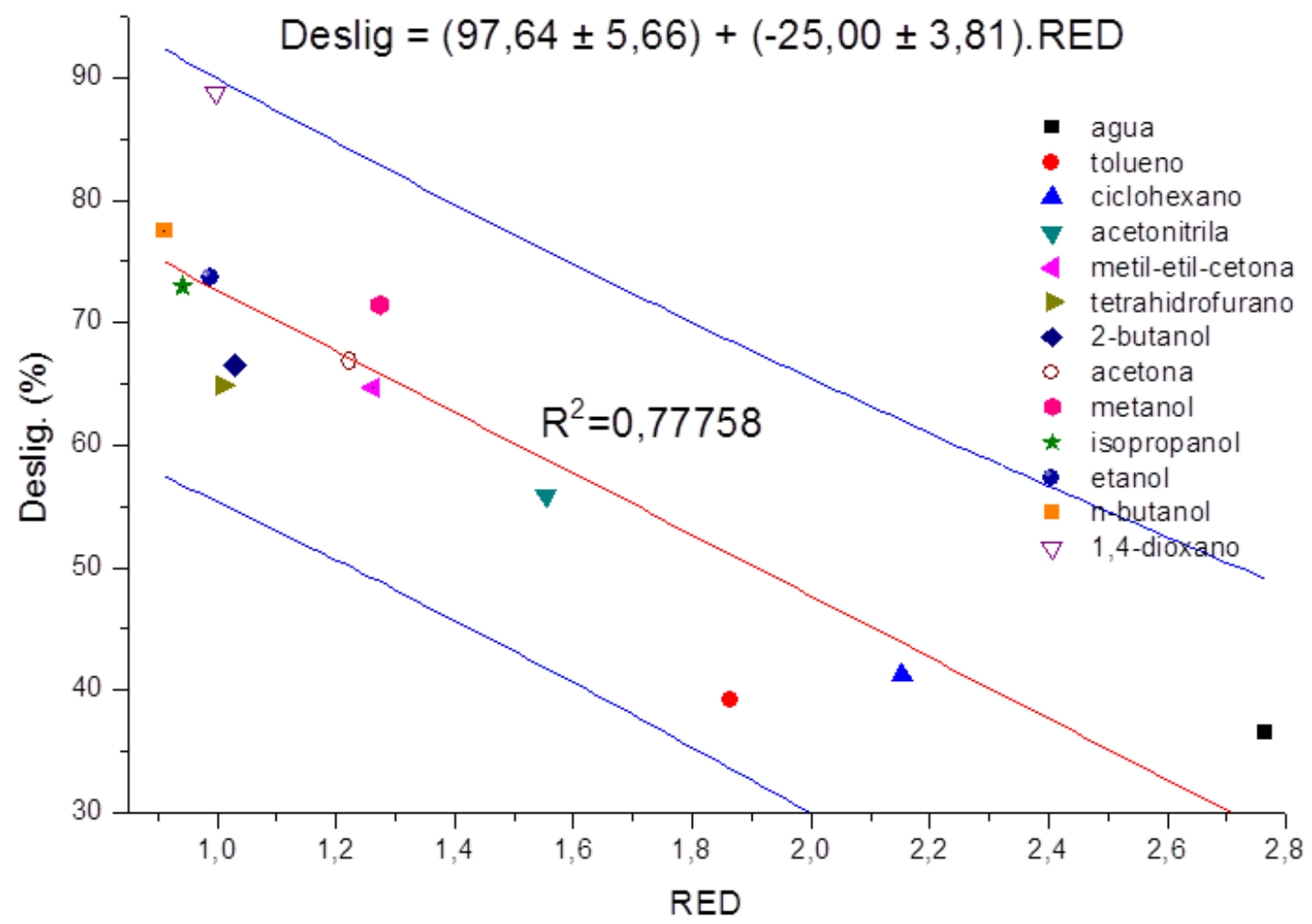

b)

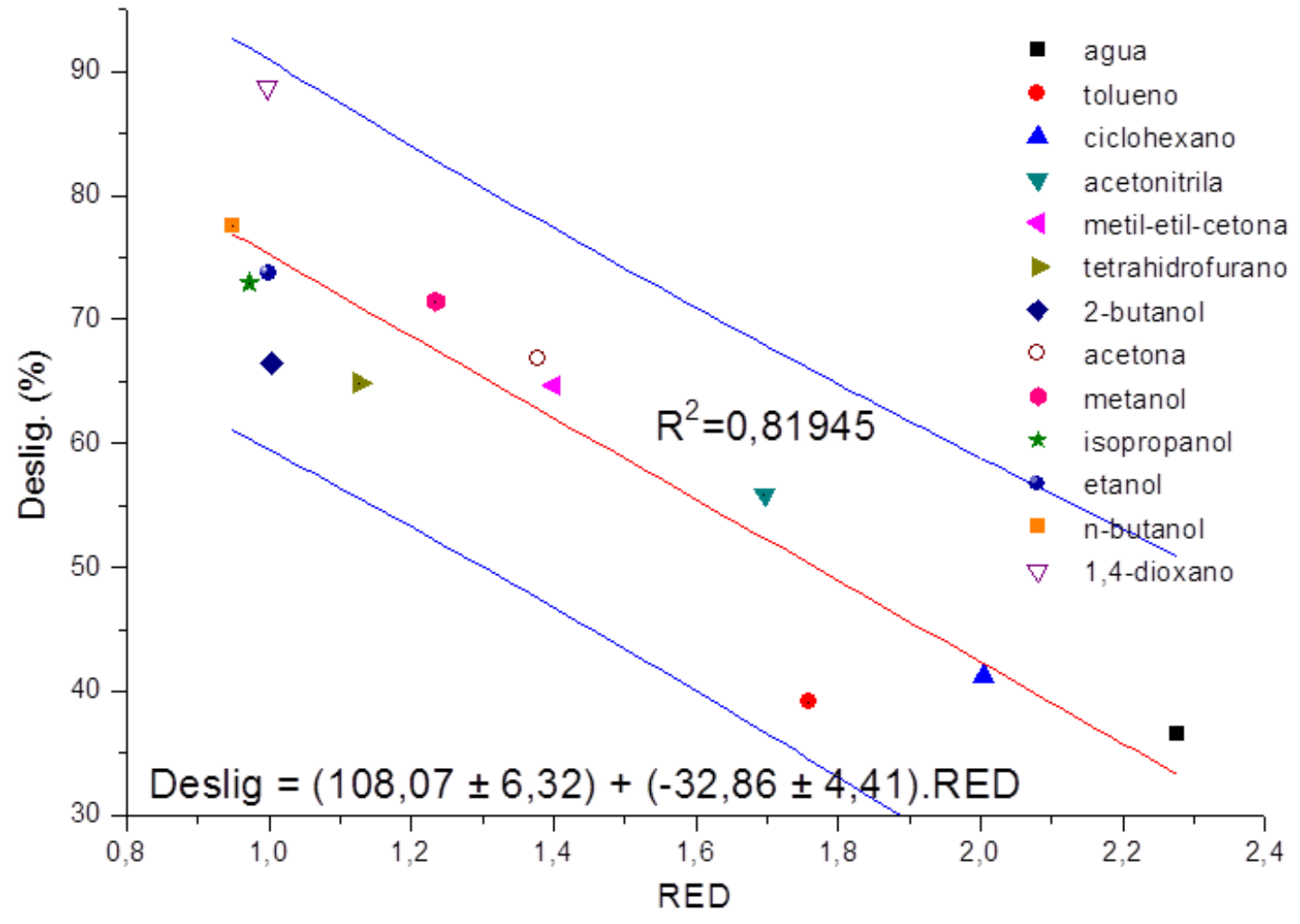


Figura 37 - Gráfico de $R_{a}$ para os parâmetros de solubilidade da corrida 3 versus deslignificação para: a) 2-butanol imiscível em água; e b) 2-butanol miscível em água.

a)

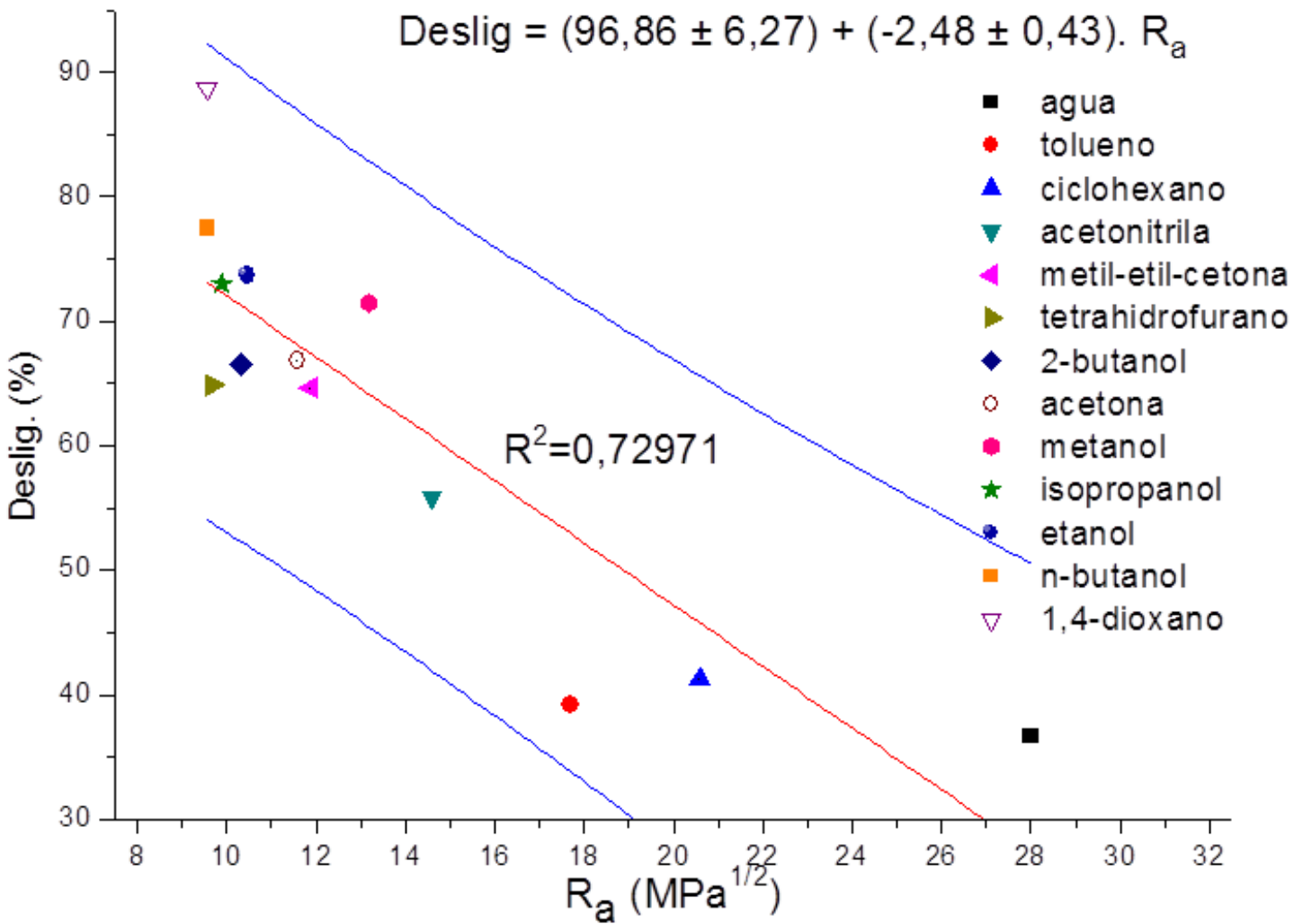

b)

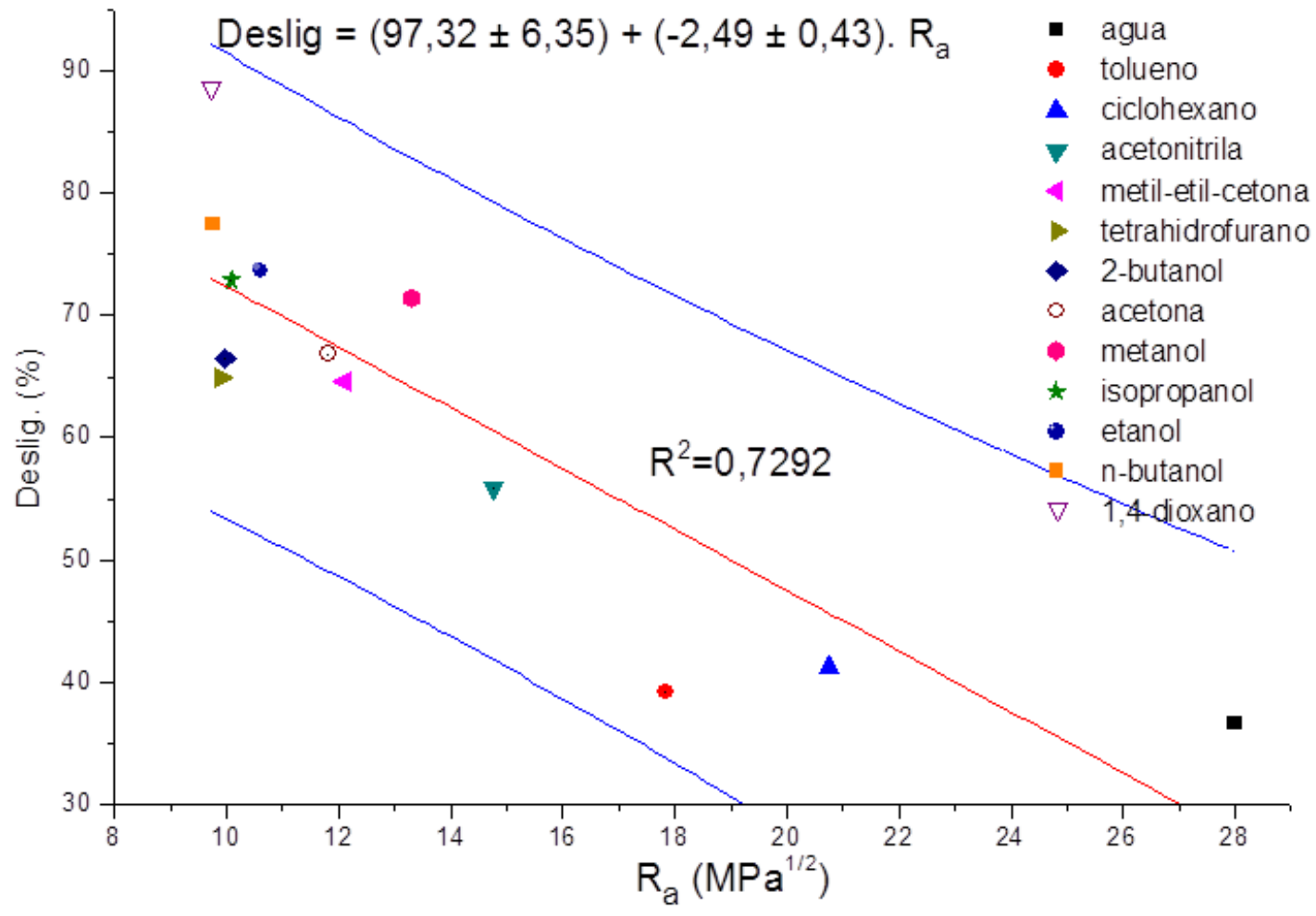


Figura 38 - Gráfico de RED para os parâmetros de solubilidade da corrida 3 versus deslignificação para: a) 2-butanol imiscível em água; e b) 2-butanol miscível em água.

a)

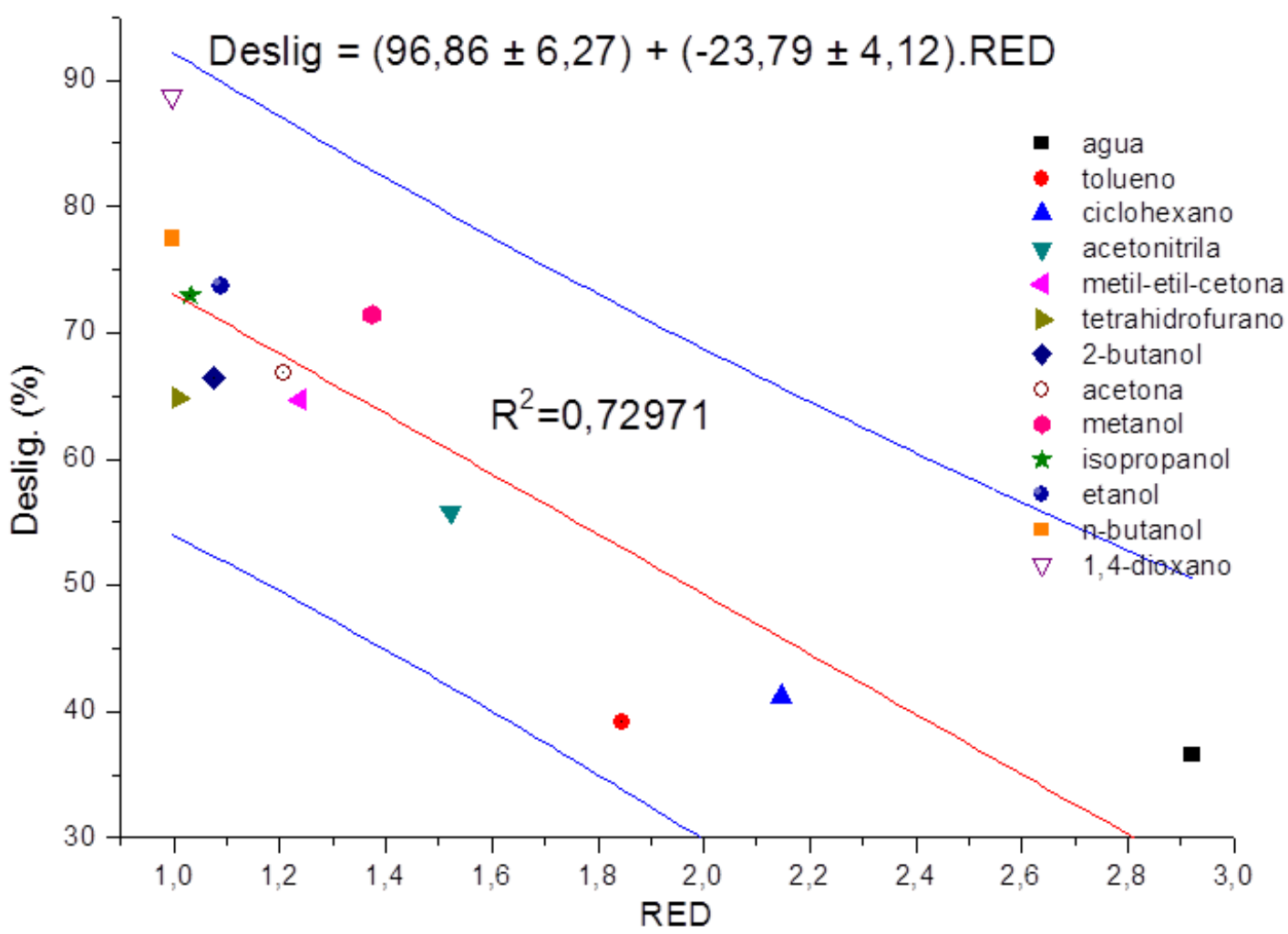

b)

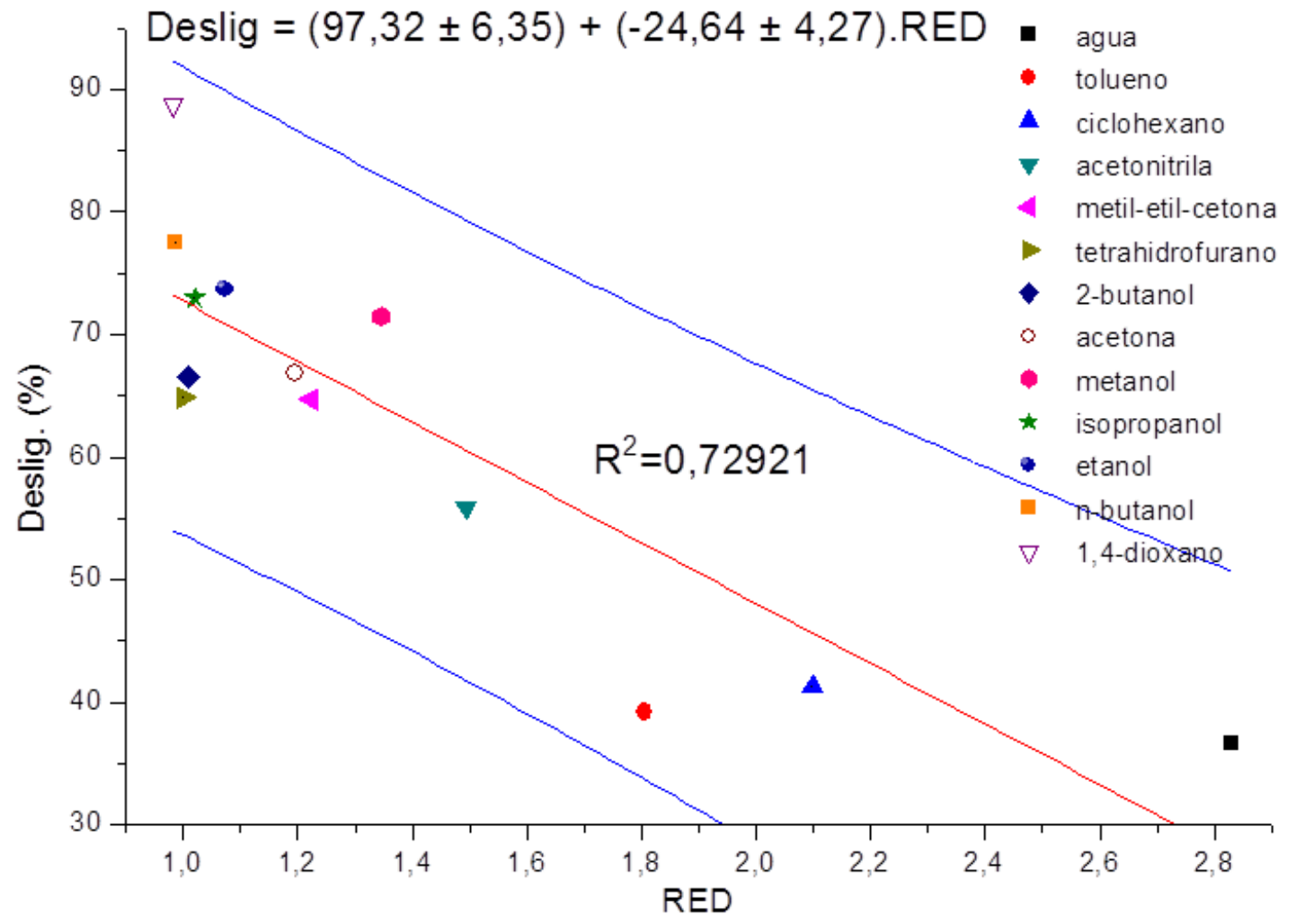


Figura 39 - Gráfico de $R_{a}$ para os parâmetros de solubilidade da corrida 4 versus deslignificação para: a) 2-butanol imiscível em água; e b) 2-butanol miscível em água.

a)

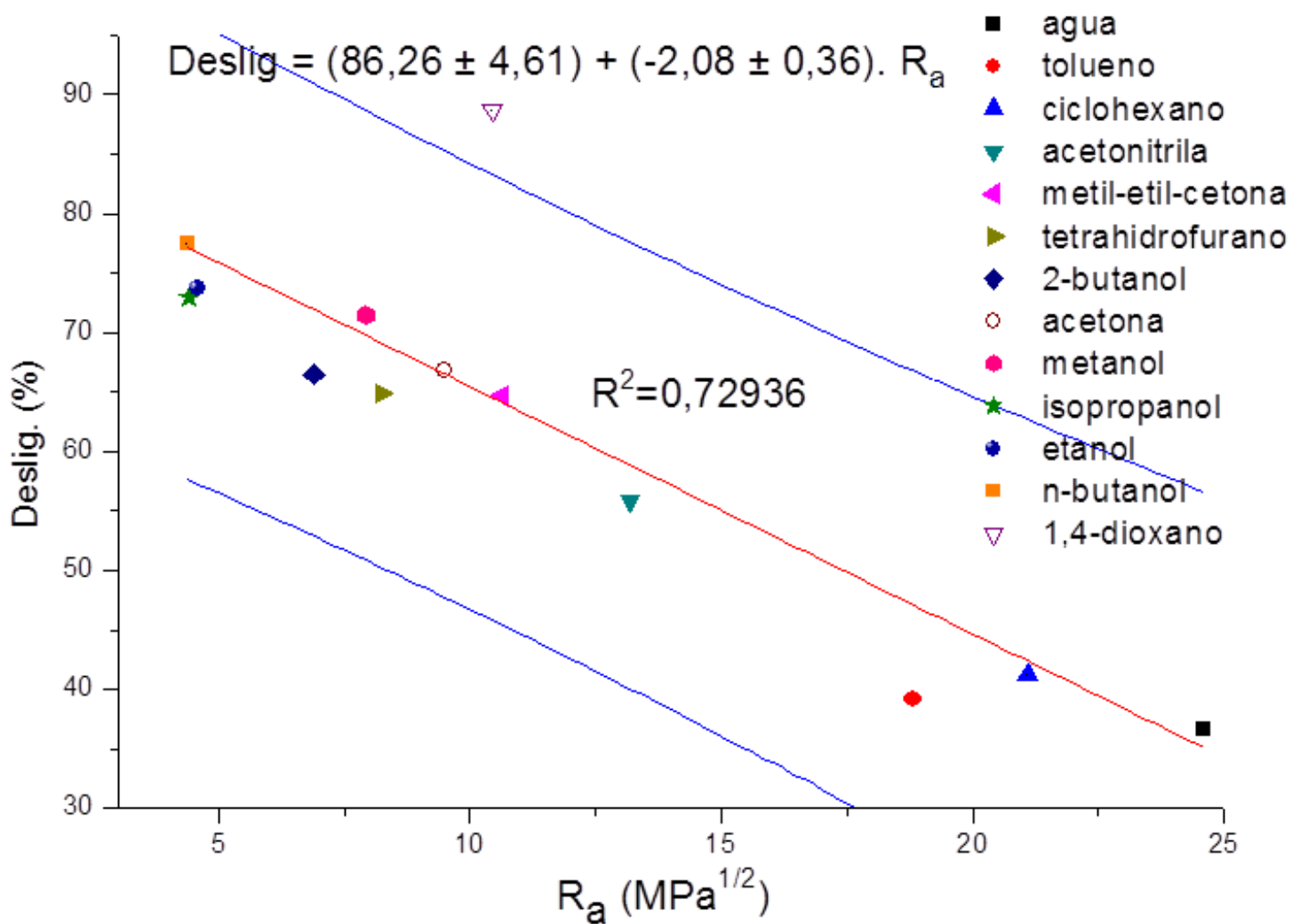

b)

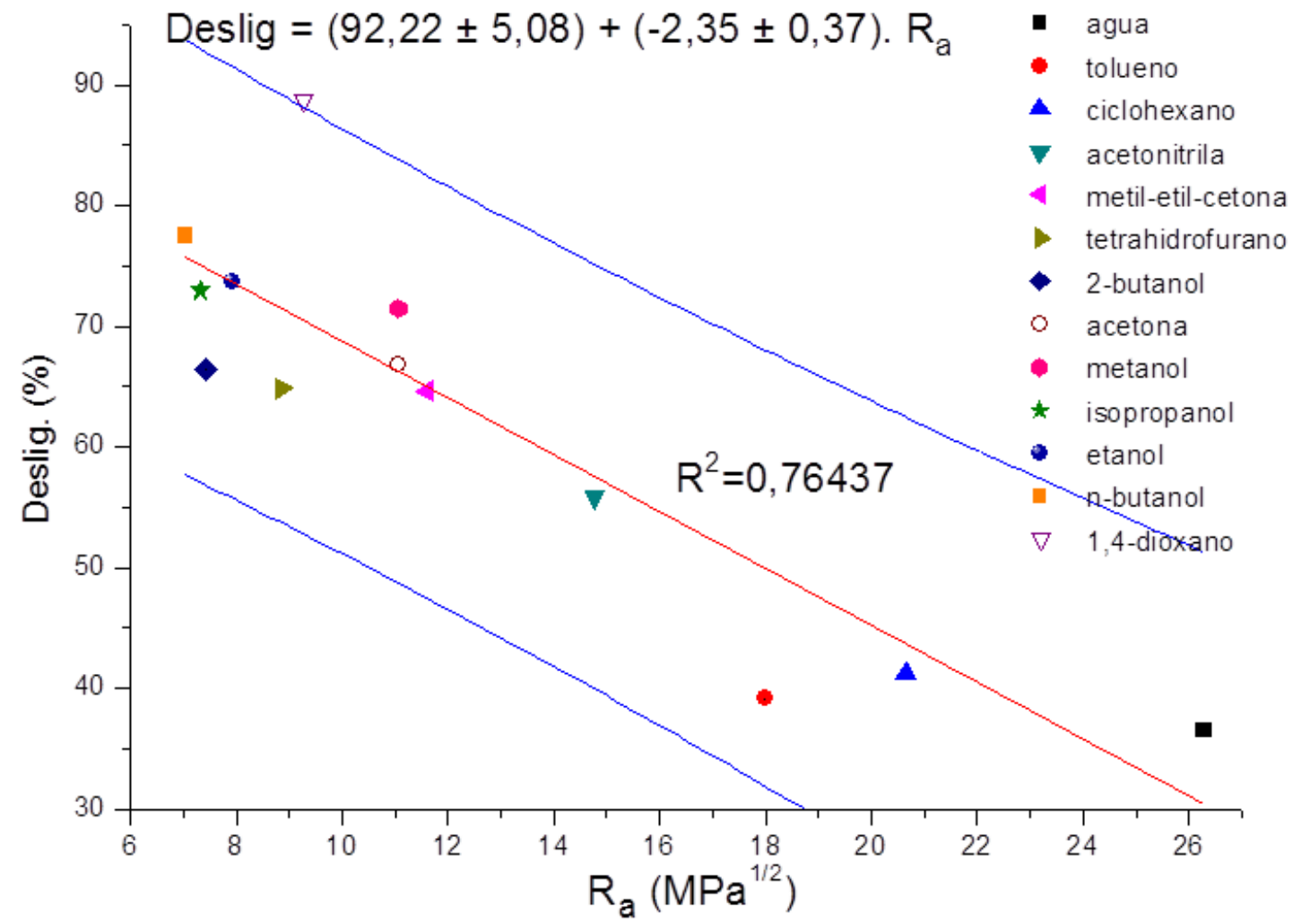


Figura 40 - Gráfico de RED para os parâmetros de solubilidade da corrida 4 versus deslignificação para: a) 2-butanol imiscível em água; e b) 2-butanol miscível em água.

a)

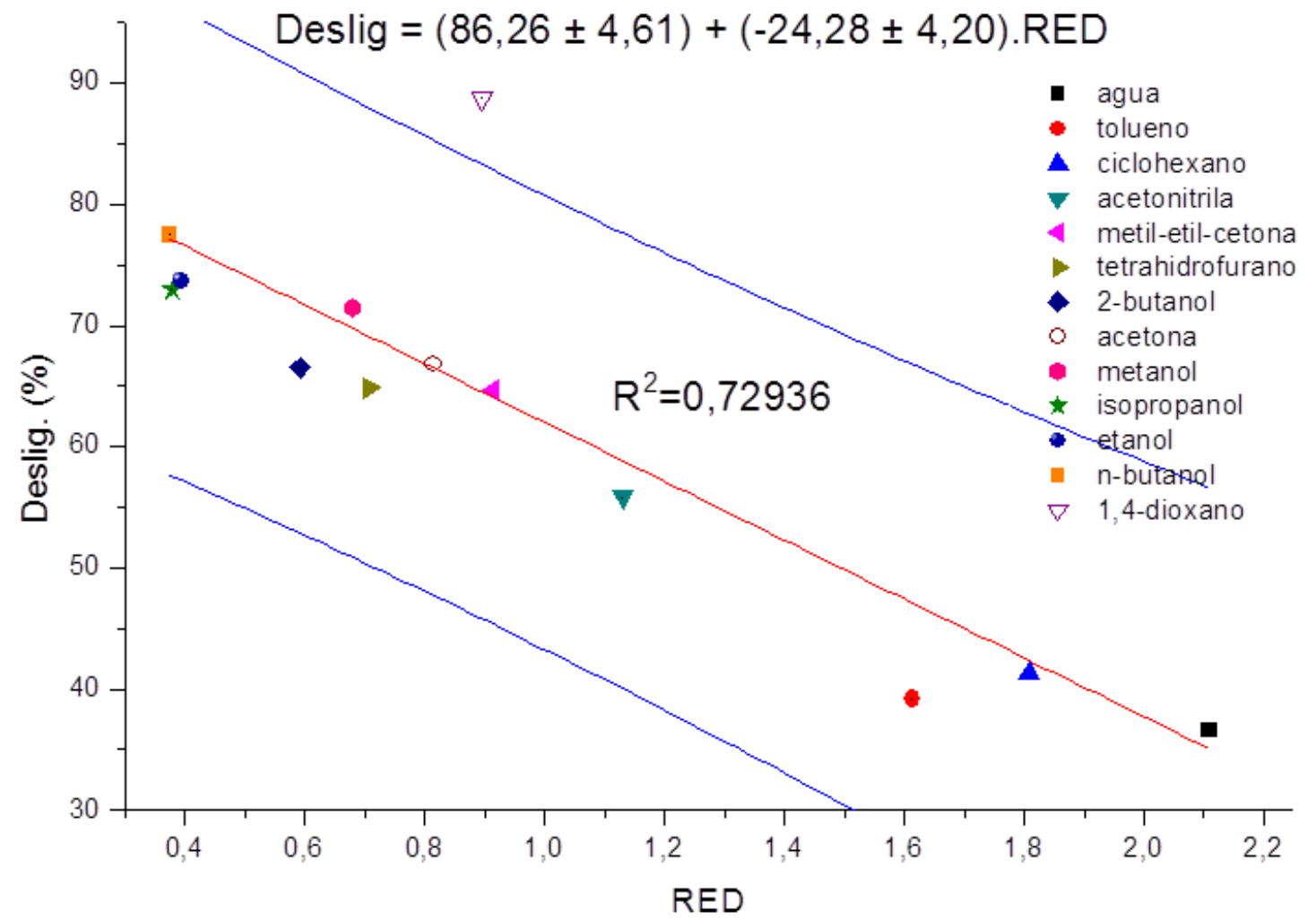

b)

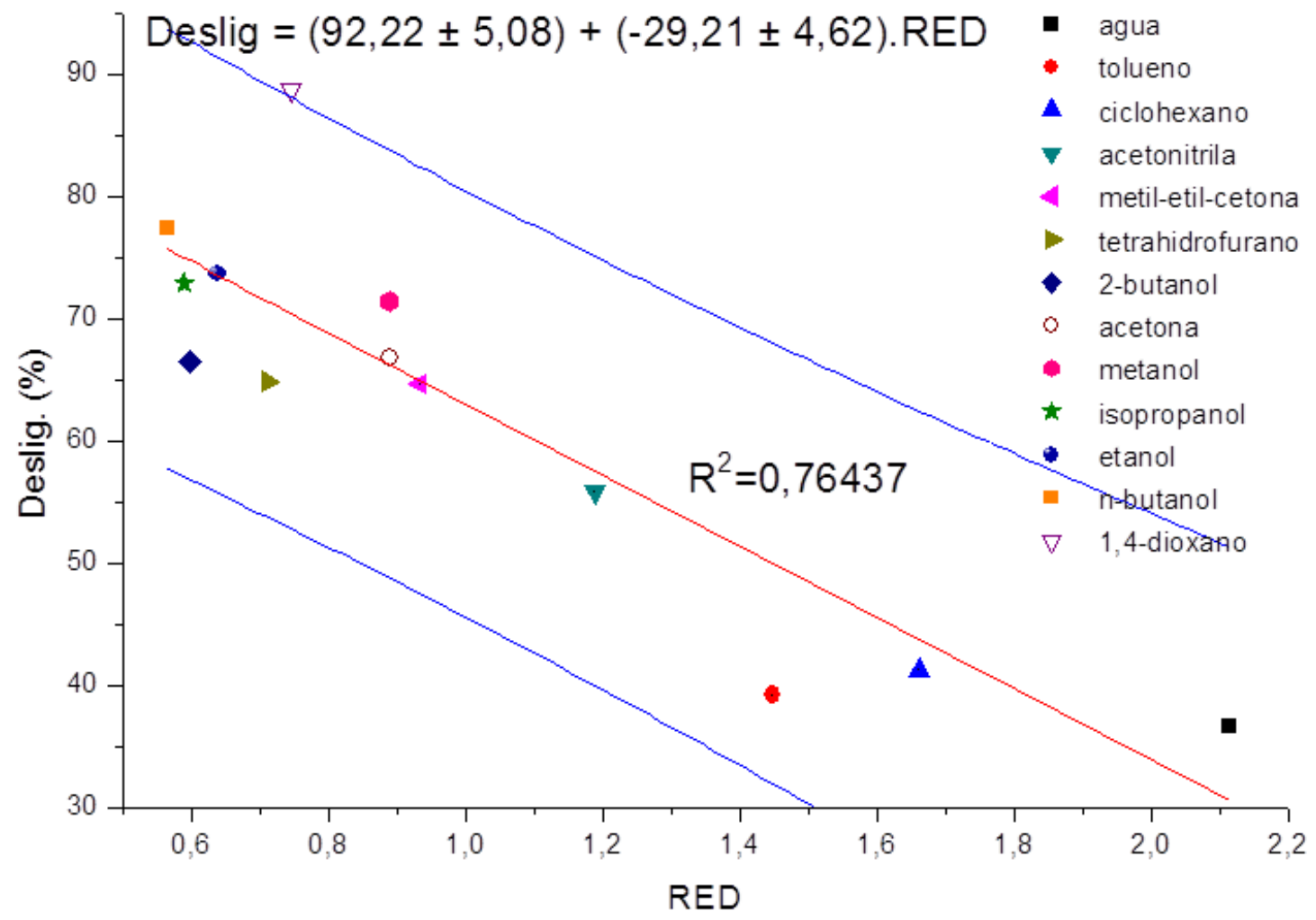


Figura 41 - Gráfico de $R_{a}$ para os parâmetros de solubilidade da corrida 5 versus deslignificação para: a) 2-butanol imiscível em água; e b) 2-butanol miscível em água.

a)

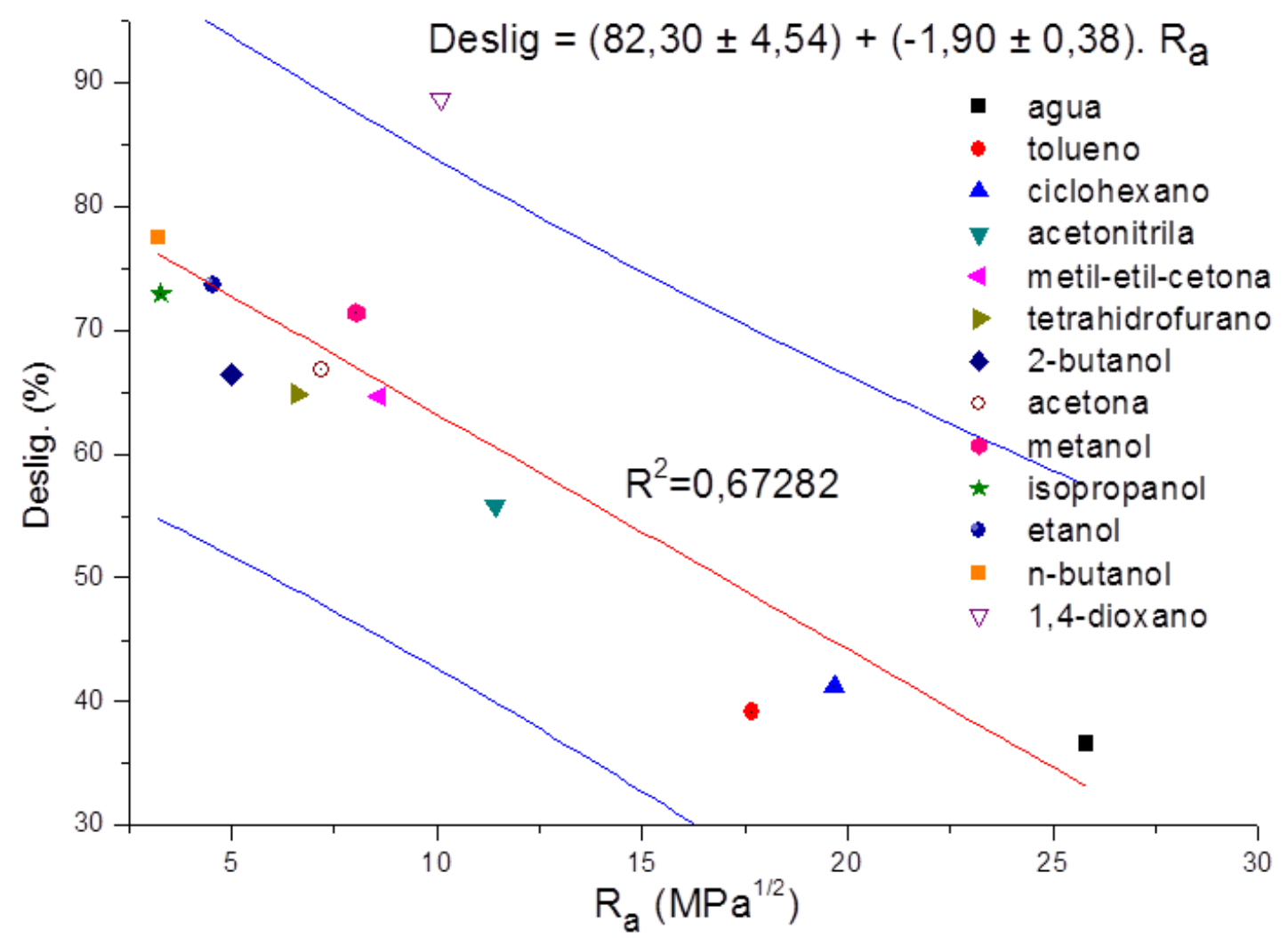

b)

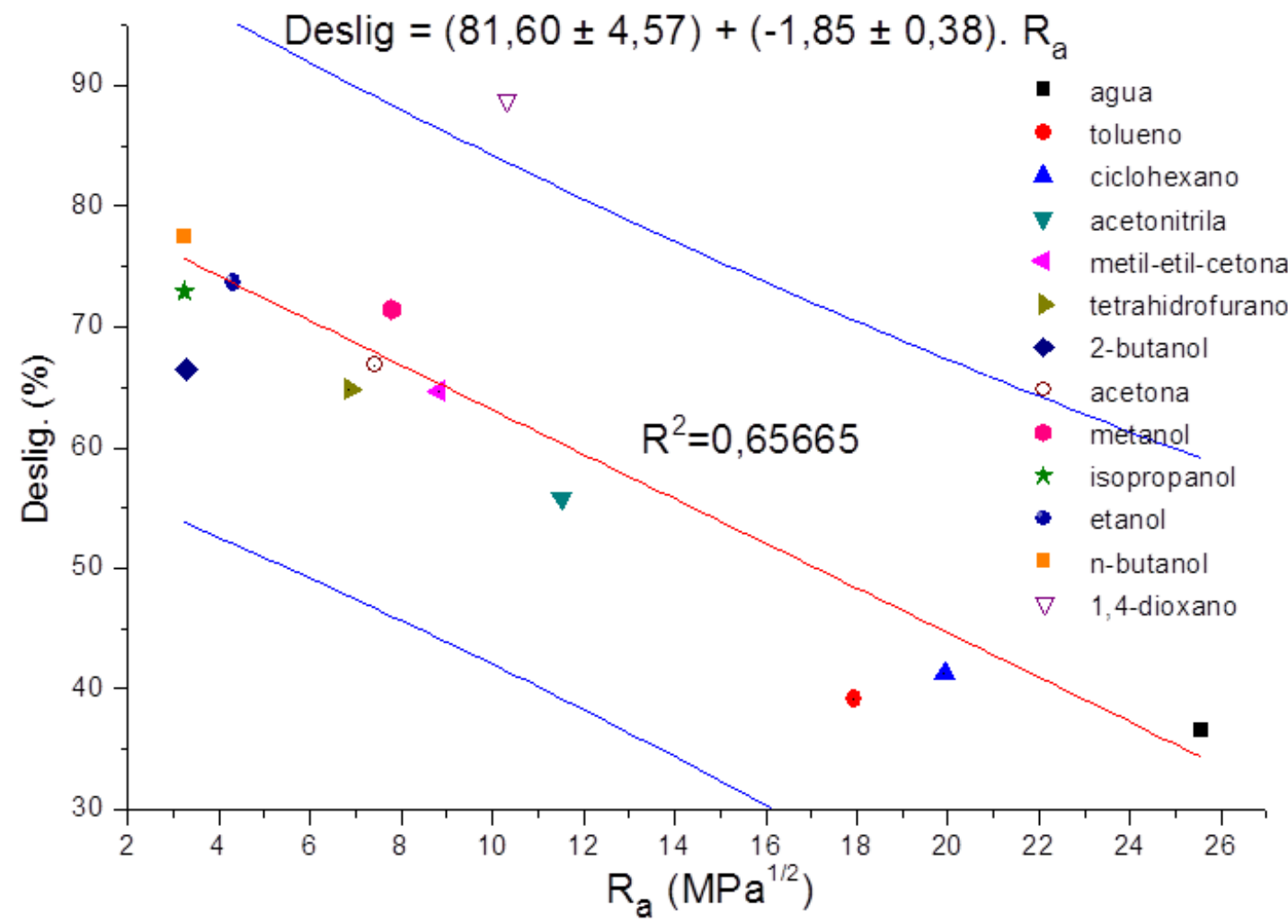


Figura 42 - Gráfico de $R E D$ para os parâmetros de solubilidade da corrida 5 versus deslignificação para: a) 2-butanol imiscível em água; e b) 2-butanol miscível em água.

a)

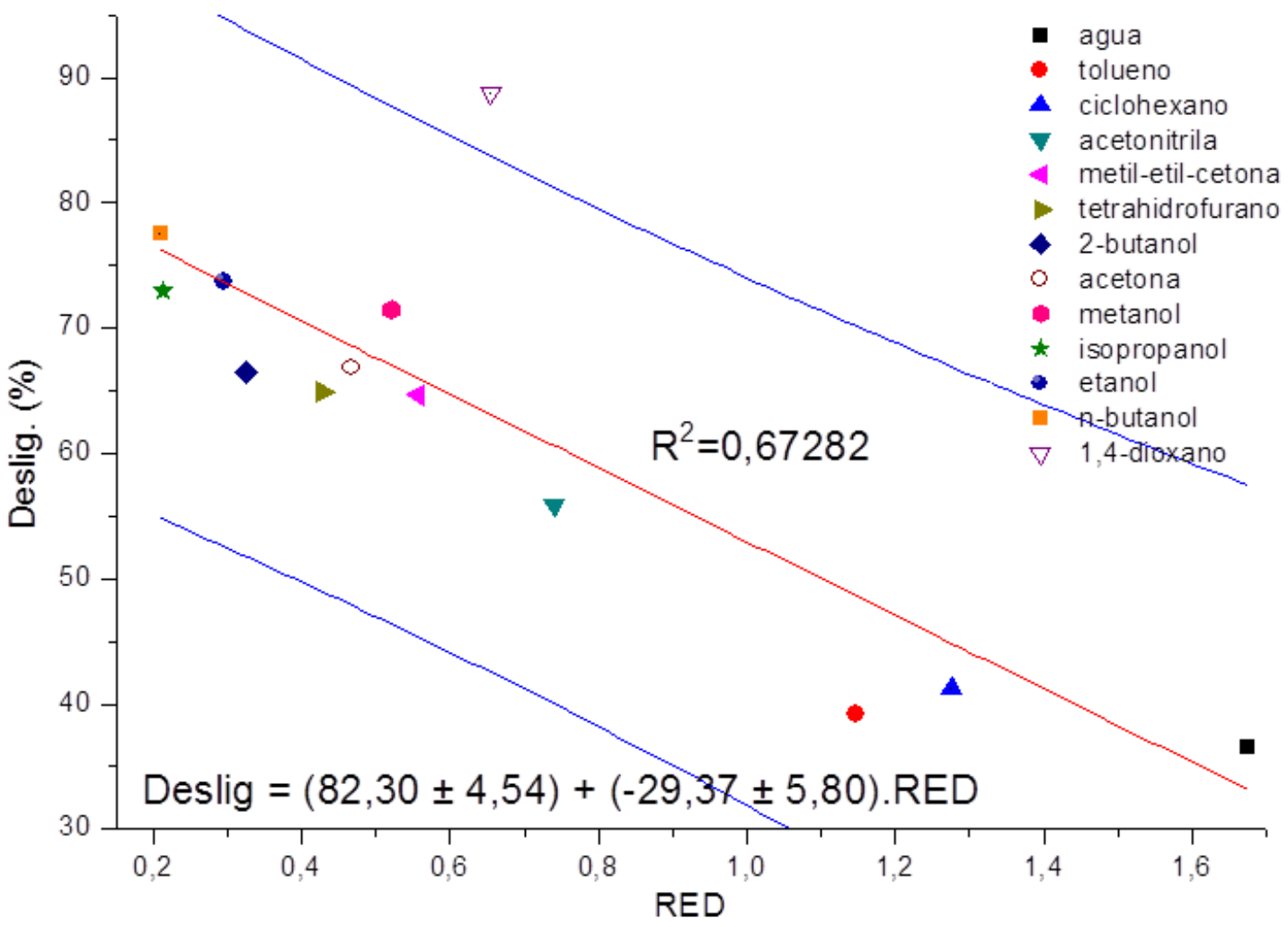

b)

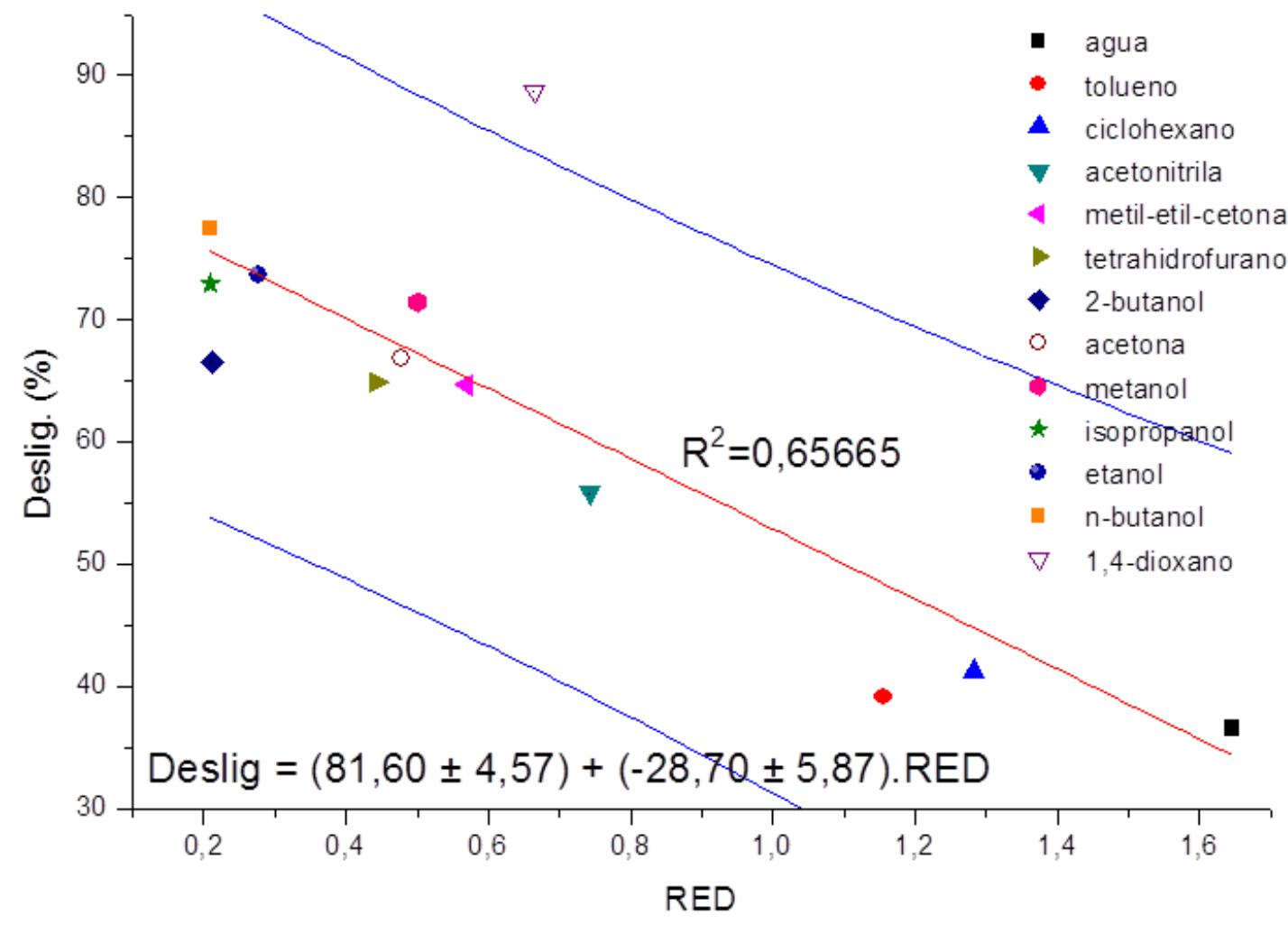

Nas figuras 33 a 42, pode-se observar além da regressão linear correspondente aos pontos, reta em vermelho, as curvas de predição com nível de confiança de 95\%, curvas em azul. 
Considerando-se os mecanismos de reação relacionados à deslignificação organossolve com catálise ácida, que é o caso deste trabalho, verifica-se que a eficiência de quebra de ligação da lignina "in situ" está diretamente ligada a presença de água, que atua como o principal nucleófilo. Desta maneira, como a concentração de água em todas as reações é a mesma, pode-se considerar que este fator não será influente nas variações de porcentagem de deslignificação, tornando a diferença entre as propriedades dos solventes responsável pela variação dos valores de deslignificação. Álcoois de cadeia curta também podem atuar como nucleófilos nas reações de deslignificação, como os casos do metanol e do etanol (BALOGH et al., 1992). Apesar de estes álcoois serem nucleófilos mais fracos do que a água, a elevada quantidade dos mesmos nas soluções, $90 \%$ do volume, faz com que estes possam de fato atuar como nucleófilos nestas reações. Desta maneira, os valores de rendimento da reação podem ter sido desviados, e consequentemente os de porcentagem de deslignificação. Contudo, como estudos a respeito da estrutura das ligninas recuperadas dos processos não foram realizados, este fator não foi levado em conta.

Desta maneira, considerando-se que todos os sistemas de solventes possuem a mesma capacidade de nucleofilicidade para agir na cisão das ligações da lignina, promovendo a formação de fragmentos, e que os parâmetros de solubilidade podem representar bem os processos de solubilidade e de acessibilidade, a relação entre os parâmetros de solubilidade dos solventes usados nas reações e as porcentagens de deslignificação devem ser relacionados diretamente (BALOGH et al., 1992). Estas relações devem obedecer, em tese, uma relação linear, visto que somente a distância entre o centro da esfera da lignina e o ponto referente ao solvente são utilizados para a comparação com os parâmetros de solubilidade de Hansen. Assim, as diferentes regressões lineares para os diferentes centros da esfera de lignina foram realizadas.

Comparando-se as figuras 33 a 42 com as figuras 30 e 31, pode-se observar que tanto para o caso da imiscibilidade do 2-butanol quando para a sua miscibilidade em água existem regressões melhor ajustadas aos pontos experimentais. Para o primeiro caso, observa-se a regressão linear da corrida 1, figuras 33 "a" e 34 "a", com um coeficiente de determinação $R^{2}$ igual a 0,84662, consideravelmente superior ao valor obtido para a regressão linear utilizando as distâncias em relação ao centro da esfera obtida por Hansen e Björkman (1998), $R^{2}$ igual a 0,72074, figuras 30 "a" e 
31 "a". Já para o segundo caso, observa-se a regressão linear para a corrida 2, figuras 35 "b" e 36 "b", com um coeficiente de determinação $R^{2}$ igual a 0,81945 , também superior ao valor obtido para a regressão linear utilizando as distâncias em relação ao centro da esfera obtida por Hansen e Björkman (1998), $R^{2}$ igual a 0,71635 , figuras 30 "b" e 31 "b".

Em ambos os casos para as regressões geradas, observa-se que todos os pontos experimentais podem ser previstos com um nível de confiança de $95 \%$. As curvas de previsão são um indicativo do quão bem um modelo pode prever a colocação de um ponto no espaço demarcado, assim, com um nível de confiança de $100 \%$ qualquer ponto poderia ser incluído no modelo, dentro dos limites do modelo, enquanto que com um nível de confiança menor como, por exemplo, 50\% a probabilidade do ponto cair entre as curvas de predição é menor, ou seja, quanto menor é o nível de confiança desejado as curvas de predição estarão mais próximas da curva da regressão linear. Estas curvas estão relacionadas ao valor de desvio do coeficiente angular, sendo a construção desta baseada em uma distribuição normal de dados. A figura 43 mostra uma curva de distribuição normal com o indicativo de números de desvios padrão em relação ao centro e a densidade de probabilidade correspondente ao conjunto de dados.

Figura 43 - Curva de distribuição normal de dados, o número de desvios padrão em relação à média e a densidade de probabilidade.

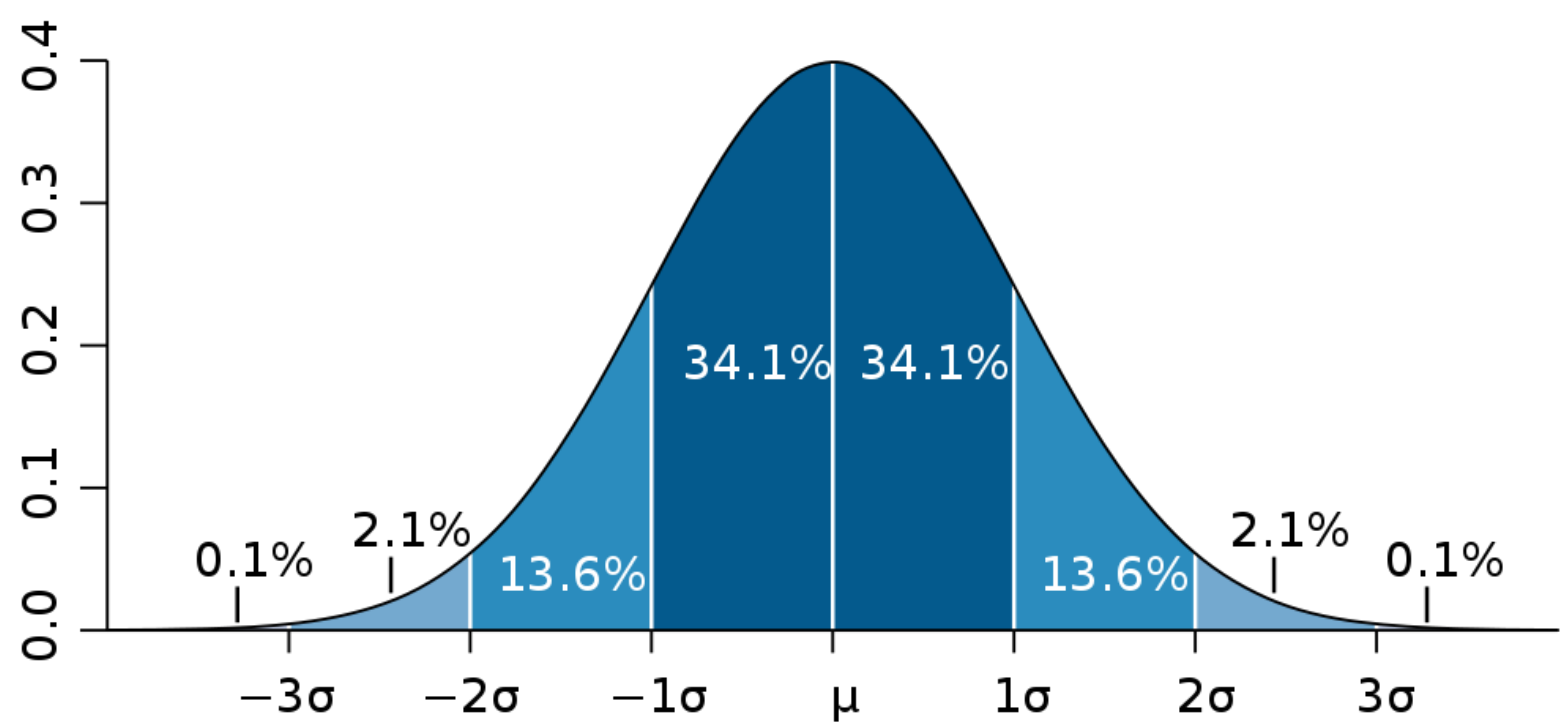

Fonte: Wikipédia, acessado em 20/01/2012.

<http://pt.wikipedia.org/wiki/Ficheiro:Standard deviation diagram.svg> 
Ademais, para os melhores ajustes, pode-se observar também que os coeficientes lineares referentes às equações que descrevem as regressões lineares são superiores a 100\%, mesmo considerando-se o erro, ou seja, para um valor de $R_{a}$ ou de $R E D$ iguais a zero, solvente coincidente com o centro da esfera da lignina, o valor de deslignificação seria superior a 100\%, o que na prática não poderia acontecer. Isto é um indicativo de que estes modelos não podem ser utilizados em toda a gama de valores de distancia e de afinidade. Parte dos desvios observados nos valores de $R_{a}$ e de $R E D$ menores, que correspondem a deslignificações mais elevadas, podem ser explicados pelo fato de que em determinado ponto a pequena quantidade de lignina presente na amostra a torna mais difícil de ser removida, tornando as taxas de deslignificação menores, além de que, em tese, algumas ligações não são quebradas em meio ácido e parte desta lignina será sempre insolúvel.

Comparando-se a regressão gerada com melhor ajuste dos dados para a imiscibilidade do 2-butanol em água, figuras 33 "a" e 34 "a”, com a regressão gerada com melhor ajuste dos dados para a miscibilidade do 2-butanol em água, figuras 35 "b" e 36 "b", é possível observar que para os primeiros existe uma maior dispersão dos dados no eixo " $x$ ", ou seja, não existem muitos pontos com valores neste eixo coincidentes, com respostas diferentes, como nos casos das regressões geradas considerando-se as distancias com relação ao centro da esfera de solubilidade da lignina obtida por Hansen e Björkman (1998), figuras 30 e 31. Já no caso da miscibilidade do 2-butanol em água, figuras 35 "b" e 36 "b", observa-se que a dispersão dos dados no eixo " $x$ " não é tão efetiva, visto que, por exemplo, para um valor de $R_{a}$ de aproximadamente $10 \mathrm{MPa}^{1 / 2}$ observa-se uma variação de respostas de cerca de 65 a 90\% de deslignificação. Assim, a princípio, dentre os dois resultados com maior ajuste, verifica-se uma melhor resposta quando se considera o 2-butanol com sendo imiscível em água.

Para a verificação dos modelos e das aplicações dos mesmos testes utilizando misturas de solventes foram realizados. 


\subsubsection{VERIFICACÃO DOS PARÂMETROS DE SOLUBILIDADE}

$\mathrm{Na}$ tabela 12 pode-se verificar as razões escolhidas entre os solventes orgânicos para as três soluções ternárias e a solução quaternária, além dos parâmetros de solubilidade destas soluções, já incluindo a razão de água adicionada à solução.

Tabela 12 - Parâmetros de solubilidade de Hansen para as três soluções ternárias e para a quaternária, e seus resultados.

\begin{tabular}{ccccccccc}
\hline $\begin{array}{c}\text { Mistura de solventes } \\
\text { orgânicos* }\end{array}$ & Razão & $\boldsymbol{\delta}_{\boldsymbol{d}}$ & $\boldsymbol{\delta}_{\boldsymbol{p}}$ & $\boldsymbol{\delta}_{\boldsymbol{h}}$ & $\begin{array}{c}\text { Rendimento } \\
\text { (\%) }\end{array}$ & $\begin{array}{c}\text { Lignina } \\
\text { total (\%) }\end{array}$ & $\begin{array}{c}\text { Deslignificação } \\
\text { (\%) }\end{array}$ \\
\hline etanol/glicerol & $80 / 20$ & 16,06 & 10,11 & 23,47 & 54,81 & 7,31 & 81,96 \\
etanol/2-butanol & $40 / 60$ & 15,77 & 7,85 & 19,04 & 54,54 & 9,66 & 76,30 \\
glicerol/2-butanol & $30 / 70$ & 16,20 & 8,46 & 21,28 & 52,27 & 6,52 & 84,67 \\
etanol/2-butanol/glicerol & $1 / 1 / 1$ & 16,25 & 9,58 & 23,19 & 56,58 & 8,55 & 78,24 \\
\hline
\end{tabular}

${ }^{*}$ Com a presença de $10 \%$ de água na mistura.

Obteve-se, então, as distancias entre os solventes e o centro das esferas de solubilidade da lignina obtidas anteriormente, $R_{a}$, e as afinidades entre os solventes e a lignina, $R E D$, utilizando as equações 11 e 12, respectivamente. As tabelas 13 e 14 mostram os valores de $R_{a}$ e $R E D$ para cada corrida e cada solução ternária ou quaternária, tanto para o caso do 2-butanol sendo imiscível em água quanto para o caso deste ser miscível, respectivamente. Observou-se nas soluções contendo o solvente 2-butanol a formação de uma fase líquida homogênea, mesmo antes da realização da deslignificação, já que este solvente é miscível tanto em glicerol quanto em etanol, sendo assim, as misturas de solventes orgânicos, miscíveis com água.

Tabela 13 - Distâncias e afinidades com a lignina das corridas e da literatura, para as três misturas ternárias e a mistura quaternárias, considerando o 2-butanol como imiscível em água.

\begin{tabular}{|c|c|c|c|c|c|c|c|c|c|c|c|c|}
\hline \multirow{2}{*}{$\begin{array}{l}\text { Mistura de } \\
\text { solventes }\end{array}$} & \multicolumn{2}{|c|}{ Corrida 1} & \multicolumn{2}{|c|}{ Corrida 2} & \multicolumn{2}{|c|}{ Corrida 3} & \multicolumn{2}{|c|}{ Corrida 4} & \multicolumn{2}{|c|}{ Corrida 5} & \multicolumn{2}{|c|}{ Literatura } \\
\hline & $\boldsymbol{R}_{\boldsymbol{a}}$ & RED & $\boldsymbol{R}_{\boldsymbol{a}}$ & RED & $\boldsymbol{R}_{\boldsymbol{a}}$ & RED & $\boldsymbol{R}_{\boldsymbol{a}}$ & RED & $\boldsymbol{R}_{\boldsymbol{a}}$ & RED & $\boldsymbol{R}_{\boldsymbol{a}}$ & $R E D$ \\
\hline etanol/glicerol/água & 13,37 & 0,83 & 10,06 & 1,03 & 10,93 & 1,14 & 5,52 & 0,47 & 6,19 & 0,40 & 13,99 & 1,02 \\
\hline $\begin{array}{c}\text { etanol/ } \\
\text { 2-butanol/água }\end{array}$ & 14,19 & 0,89 & 9,07 & 0,93 & 9,71 & 1,01 & 4,05 & 0,35 & 2,79 & 0,18 & 13,93 & 1,02 \\
\hline $\begin{array}{c}\text { glicerol/ } \\
\text { 2-butanol/água }\end{array}$ & 12,95 & 0,81 & 8,77 & 0,90 & 9,60 & 1,00 & 3,81 & 0,33 & 4,12 & 0,27 & 13,45 & 0,98 \\
\hline $\begin{array}{l}\text { etanol/glicerol/ } \\
\text { 2-butanol/água }\end{array}$ & 12,90 & 0,80 & 9,56 & 0,98 & 10,46 & 1,09 & 5,04 & 0,43 & 5,85 & 0,38 & 13,70 & 1,00 \\
\hline
\end{tabular}


Tabela 14 - Distâncias e afinidades com a lignina das corridas, para as três misturas ternárias e a mistura quaternária, considerando o 2-butanol como miscível em água.

\begin{tabular}{cccccccccccc}
\hline \multirow{2}{*}{ Mistura de solventes } & \multicolumn{3}{c}{ Corrida 1 } & \multicolumn{3}{c}{ Corrida 2 } & \multicolumn{2}{c}{ Corrida 3 } & \multicolumn{2}{c}{ Corrida 4 } & \multicolumn{2}{c}{ Corrida 5 } \\
& $\boldsymbol{R}_{\boldsymbol{a}}$ & $\boldsymbol{R E D}$ & $\boldsymbol{R}_{\boldsymbol{a}}$ & $\boldsymbol{R E D}$ & $\boldsymbol{R}_{\boldsymbol{a}}$ & $\boldsymbol{R E D}$ & $\boldsymbol{R}_{\boldsymbol{a}}$ & $\boldsymbol{R} \boldsymbol{E} \boldsymbol{D}$ & $\boldsymbol{R}_{\boldsymbol{a}}$ & $\boldsymbol{R} \boldsymbol{E} \boldsymbol{D}$ \\
\hline etanol/glicerol/água & 25,40 & 0,92 & 11,54 & 0,99 & 11,06 & 1,12 & 8,48 & 0,68 & 5,94 & 0,38 \\
etanol/2-butanol/água & 27,12 & 0,98 & 11,34 & 0,98 & 9,91 & 1,00 & 7,20 & 0,58 & 2,71 & 0,17 \\
glicerol/2-butanol/água & 25,50 & 0,92 & 10,50 & 0,90 & 9,76 & 0,99 & 6,95 & 0,56 & 3,91 & 0,25 \\
$\begin{array}{c}\text { etanol/glicerol/ } \\
\text { 2-butanol/água }\end{array}$ & 24,98 & 0,90 & 10,96 & 0,94 & 10,59 & 1,07 & 7,94 & 0,64 & 5,60 & 0,36 \\
\hline
\end{tabular}

Analisando as tabelas 12, 13 e 14, pode-se observar que para as misturas terciárias e para a mistura quaternária dos solventes orgânicos de baixo custo e/ou excedentes no mercado possuíram de fato uma deslignificação superior a do que a maioria das misturas de um único solvente orgânico com água. Observa-se também que estas misturas possuem valores de $R E D$ inferiores a 1,0 para a maioria das esferas de solubilidade obtidas, ou seja, que seriam soluções com boa afinidade com a lignina, enquanto que em relação ao centro da esfera de solubilidade da lignina verificado na literatura possuem valores superiores a 1,0, com exceção da solução composta de 2-butanol, glicerol e água que possui $R E D$ igual a 0,98 . $O$ fato das reações com estas misturas fornecerem bons resultados, melhores do que o dos solventes individuais nas soluções com água, e do fato dos valores de RED serem menores do 1,0 na maioria das corridas, é um indicativo de que a esfera de solubilidade da lignina obtida por Hansen e Björkman (1998) não é adequada para ser correlacionada com os teores de deslignificação quanto aplicadas ao bagaço de cana-de-açúcar.

Nas figuras 44 a 55 pode-se observar os gráficos relacionando as distancias e das afinidades entre os parâmetros de solubilidade das misturas binárias, ternárias e quaternária e o centro das esferas de solubilidade da lignina, da literatura e das corridas, considerando os casos do 2-butanol sendo imiscível e miscível em água. Nestes gráficos, pode-se observar os pontos que geraram a regressão linear em preto, referentes às misturas binárias, as mesmas regressões lineares obtidas anteriormente, em vermelho, curvas de predição para o nível de confiança de 95\%, em azul, e os diferentes pontos referentes às misturas de solventes orgânicos, mostrados individualmente. Em cada figura pode-se verificar, comparativamente, os casos de imiscibilidade e miscibilidade do 2-butanol em água, respectivamente, iniciando pelas relações com o centro da esfera de solubilidade verificada na 
literatura e em seguida as relações para as diferentes corridas realizadas anteriormente.

Figura 44 - Gráfico de $R_{a}$ para as misturas terciárias e a mistura quaternária em relação aos parâmetros de solubilidade da literatura versus deslignificação para: a) 2-butanol imiscível em água; e b) 2-butanol miscível em água.

a)

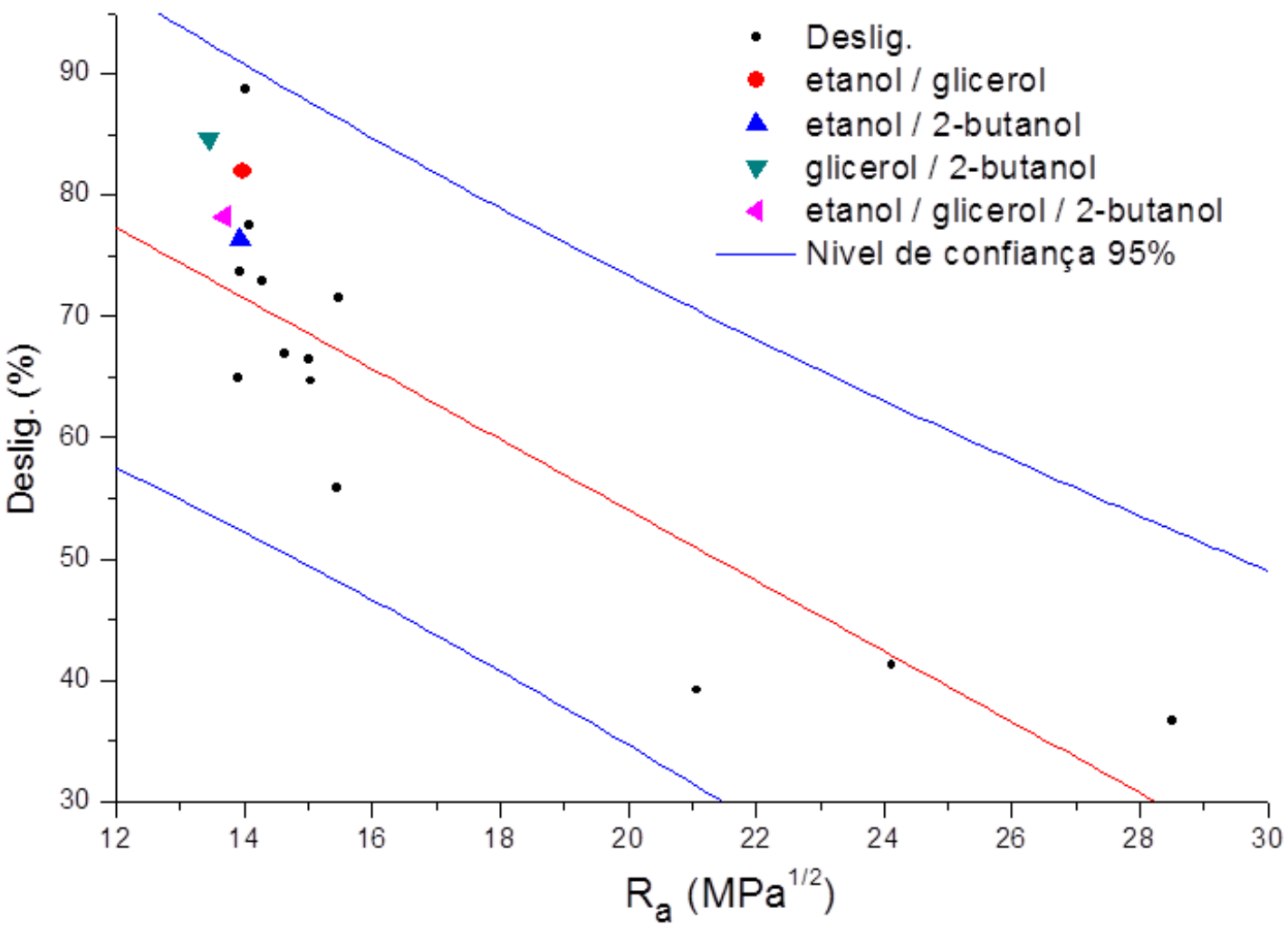

b)

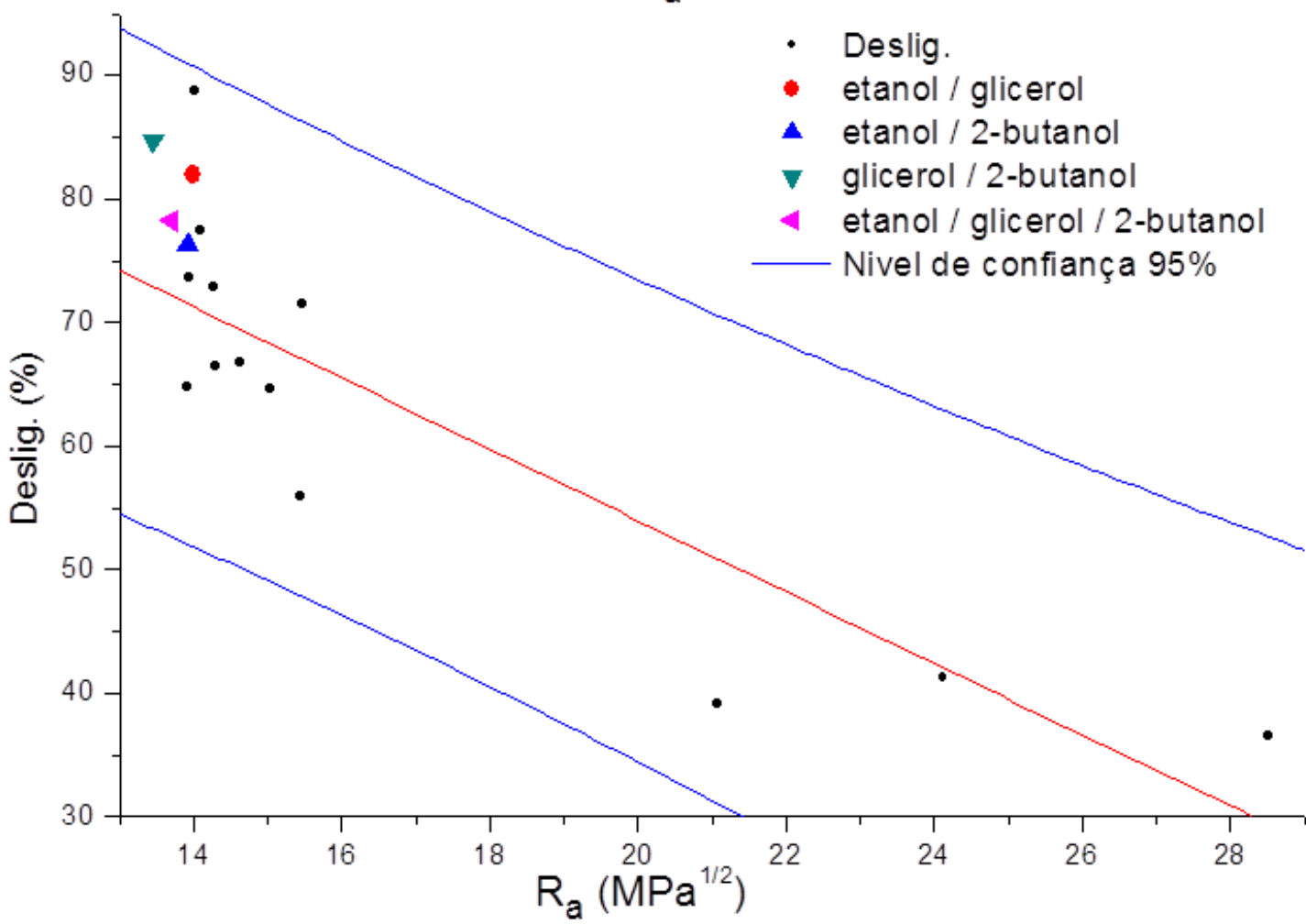


Figura 45 - Gráfico de RED para as misturas terciárias e a mistura quaternária em relação aos parâmetros de solubilidade da literatura versus deslignificação para: a) 2-butanol imiscível em água; e b) 2-butanol miscível em água.
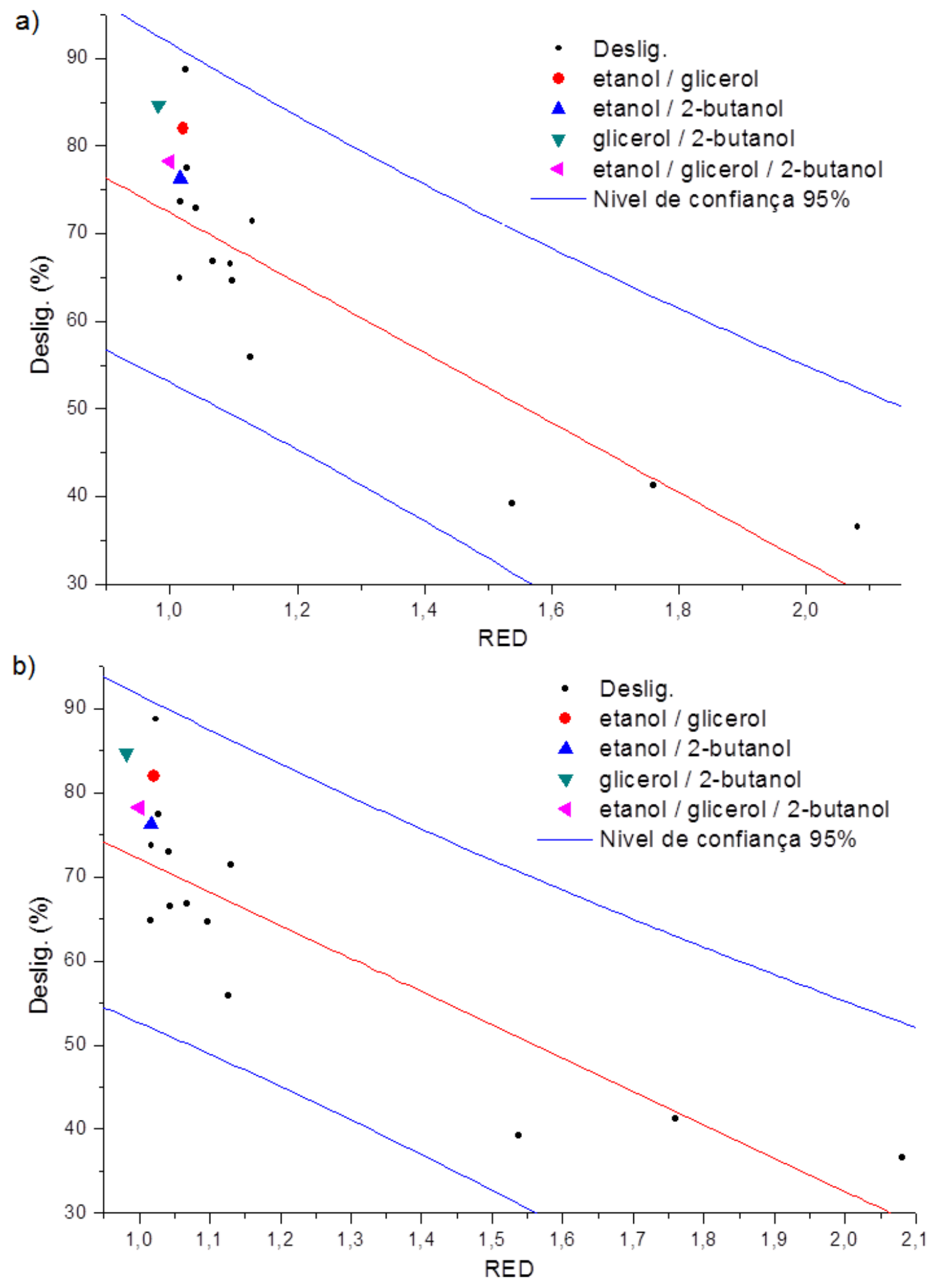
Figura 46 - Gráfico de $R_{a}$ para as misturas terciárias e a mistura quaternária em relação aos parâmetros de solubilidade da corrida 1 versus deslignificação para: a) 2-butanol imiscível em água; e b) 2-butanol miscível em água.

a)

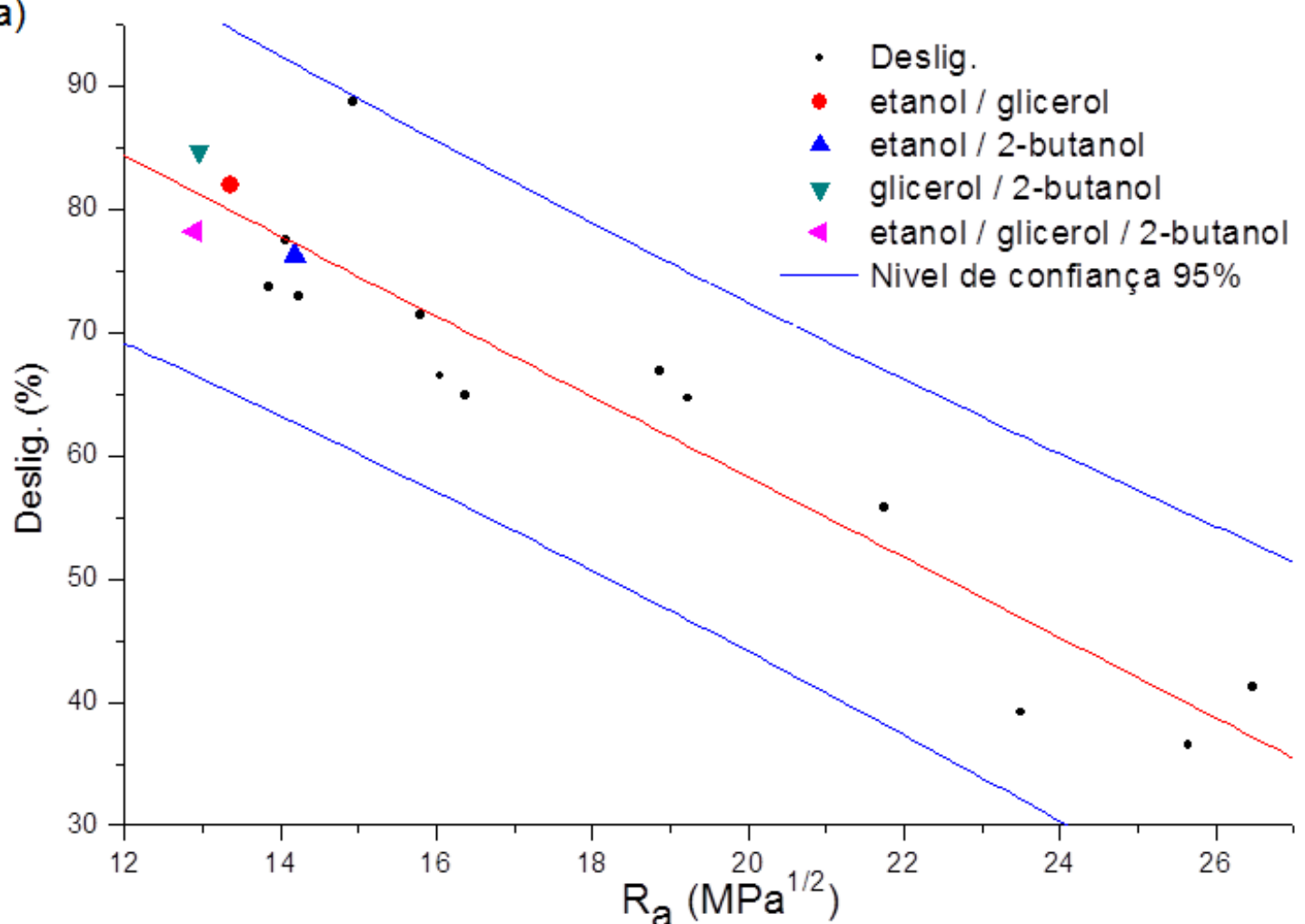

b)

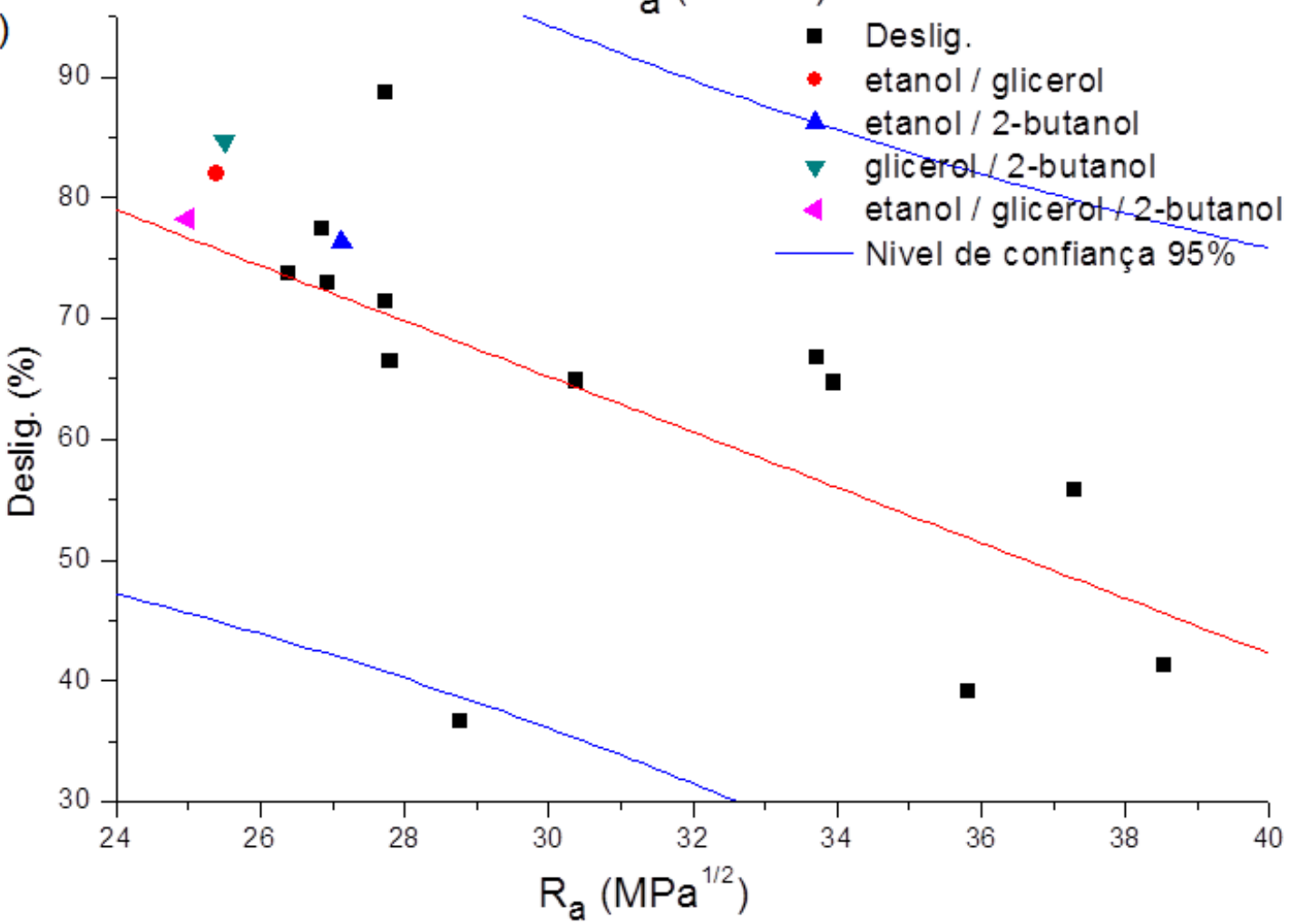


Figura 47 - Gráfico de RED para as misturas terciárias e a mistura quaternária em relação aos parâmetros de solubilidade da corrida 1 versus deslignificação para: a) 2-butanol imiscível em água; e b) 2-butanol miscível em água.
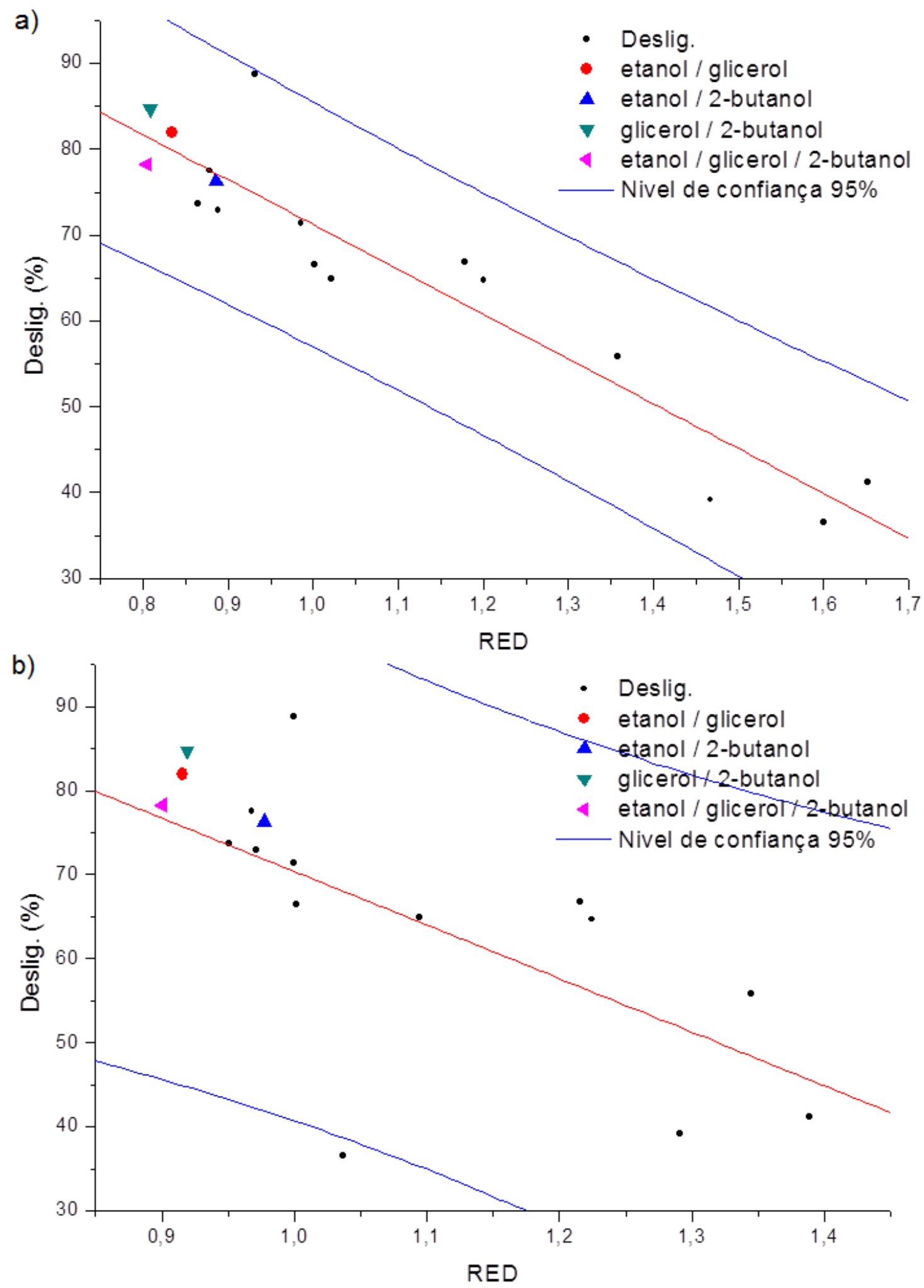
Figura 48 - Gráfico de $R_{a}$ para as misturas terciárias e a mistura quaternária em relação aos parâmetros de solubilidade da corrida 2 versus deslignificação para: a) 2-butanol imiscível em água; e b) 2-butanol miscível em água.
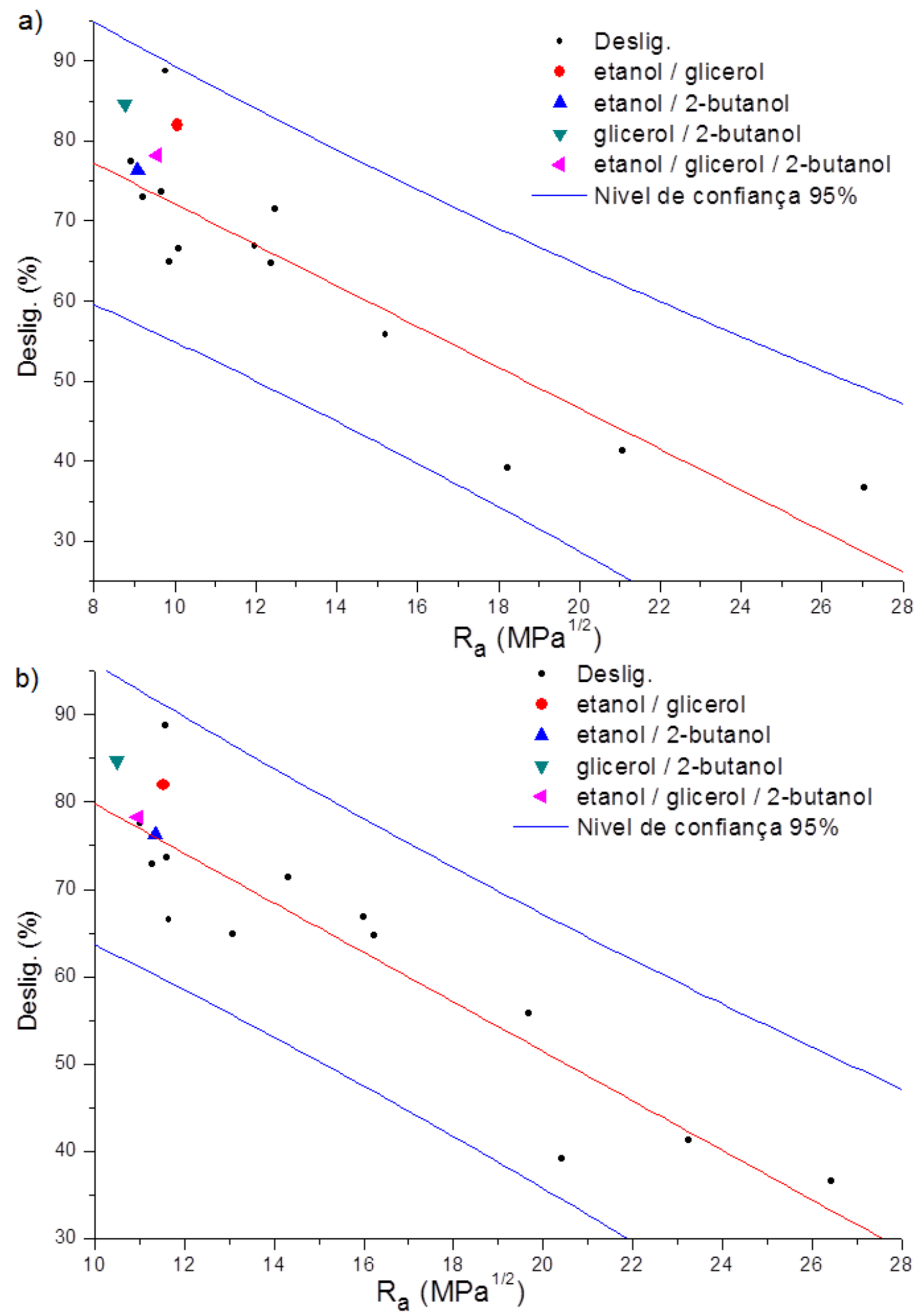
Figura 49 - Gráfico de RED para as misturas terciárias e a mistura quaternária em relação aos parâmetros de solubilidade da corrida 2 versus deslignificação para: a) 2-butanol imiscível em água; e b) 2-butanol miscível em água.

a)
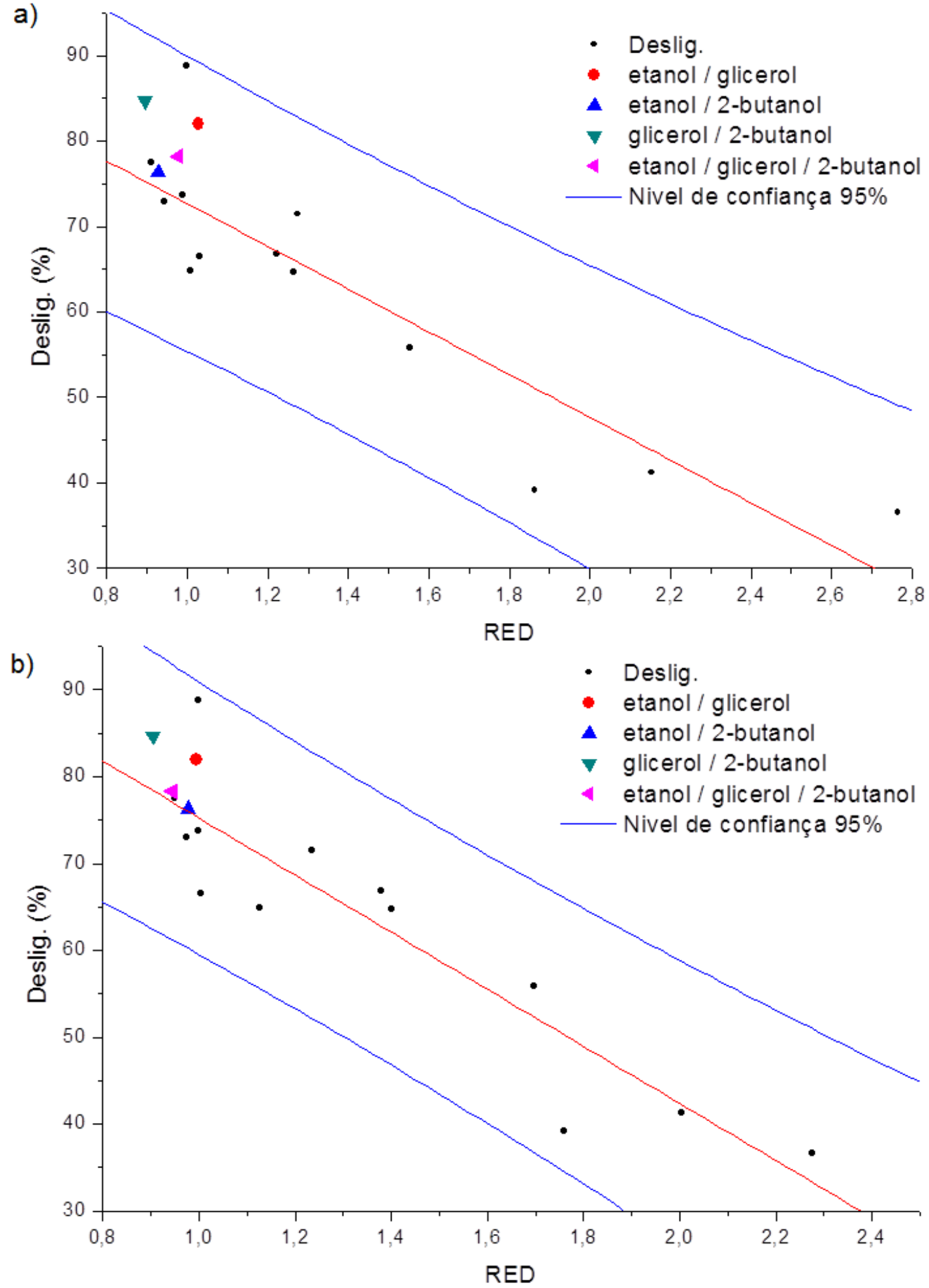
Figura 50 - Gráfico de $R_{a}$ para as misturas terciárias e a mistura quaternária em relação aos parâmetros de solubilidade da corrida 3 versus deslignificação para: a) 2-butanol imiscível em água; e b) 2-butanol miscível em água.

a)

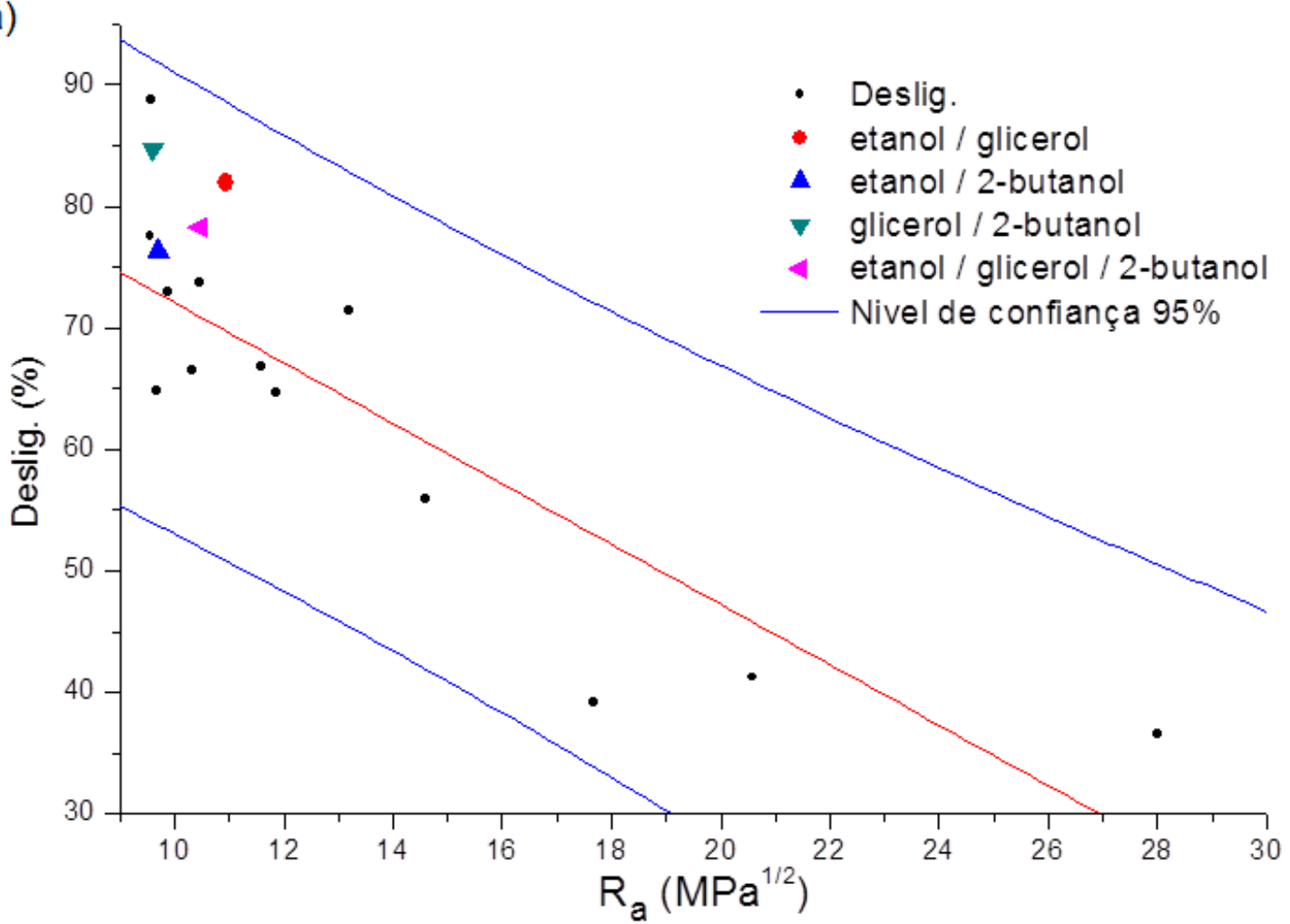

b)

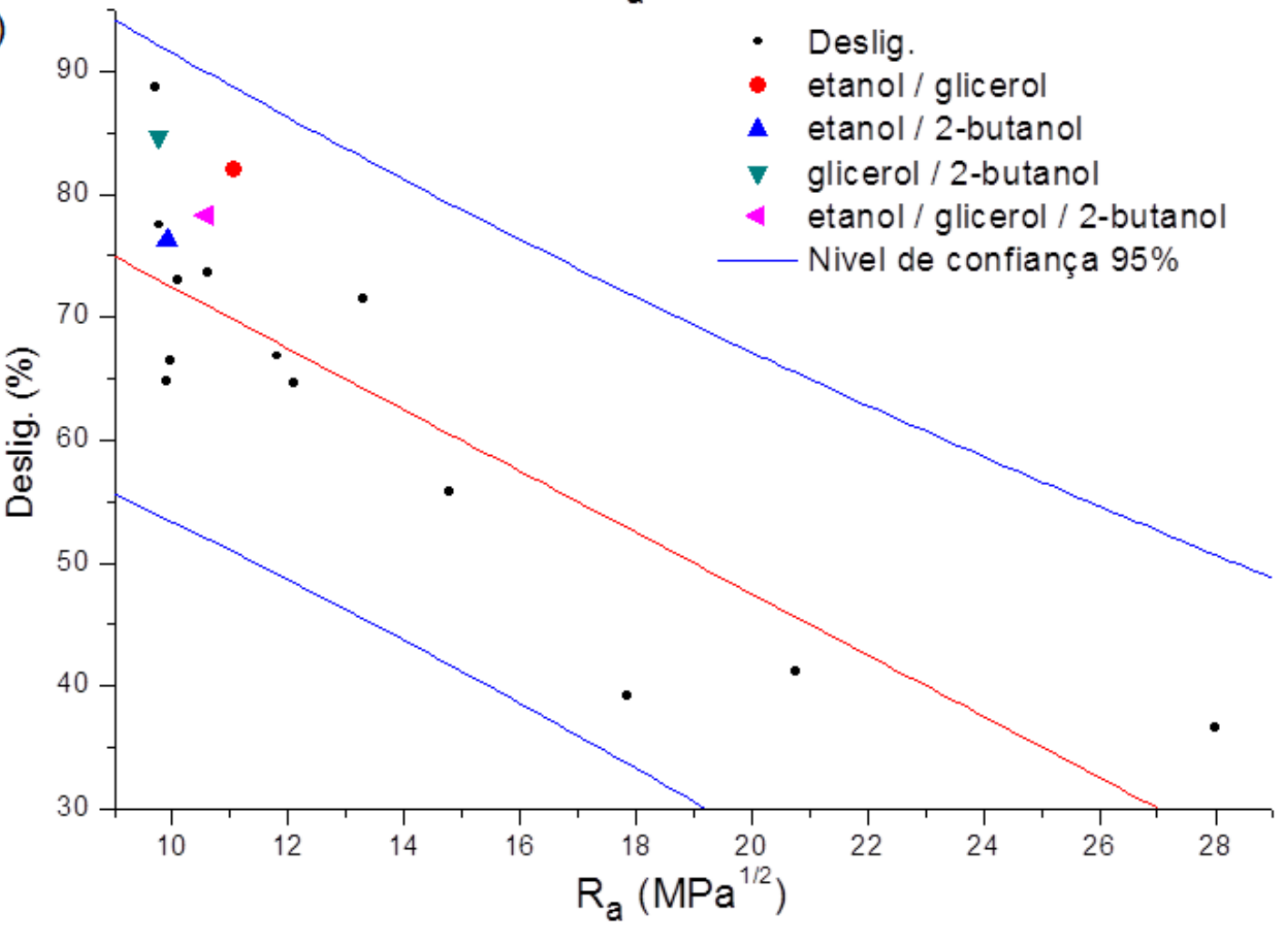


Figura 51 - Gráfico de RED para as misturas terciárias e a mistura quaternária em relação aos parâmetros de solubilidade da corrida 3 versus deslignificação para: a) 2-butanol imiscível em água; e b) 2-butanol miscível em água.

a)
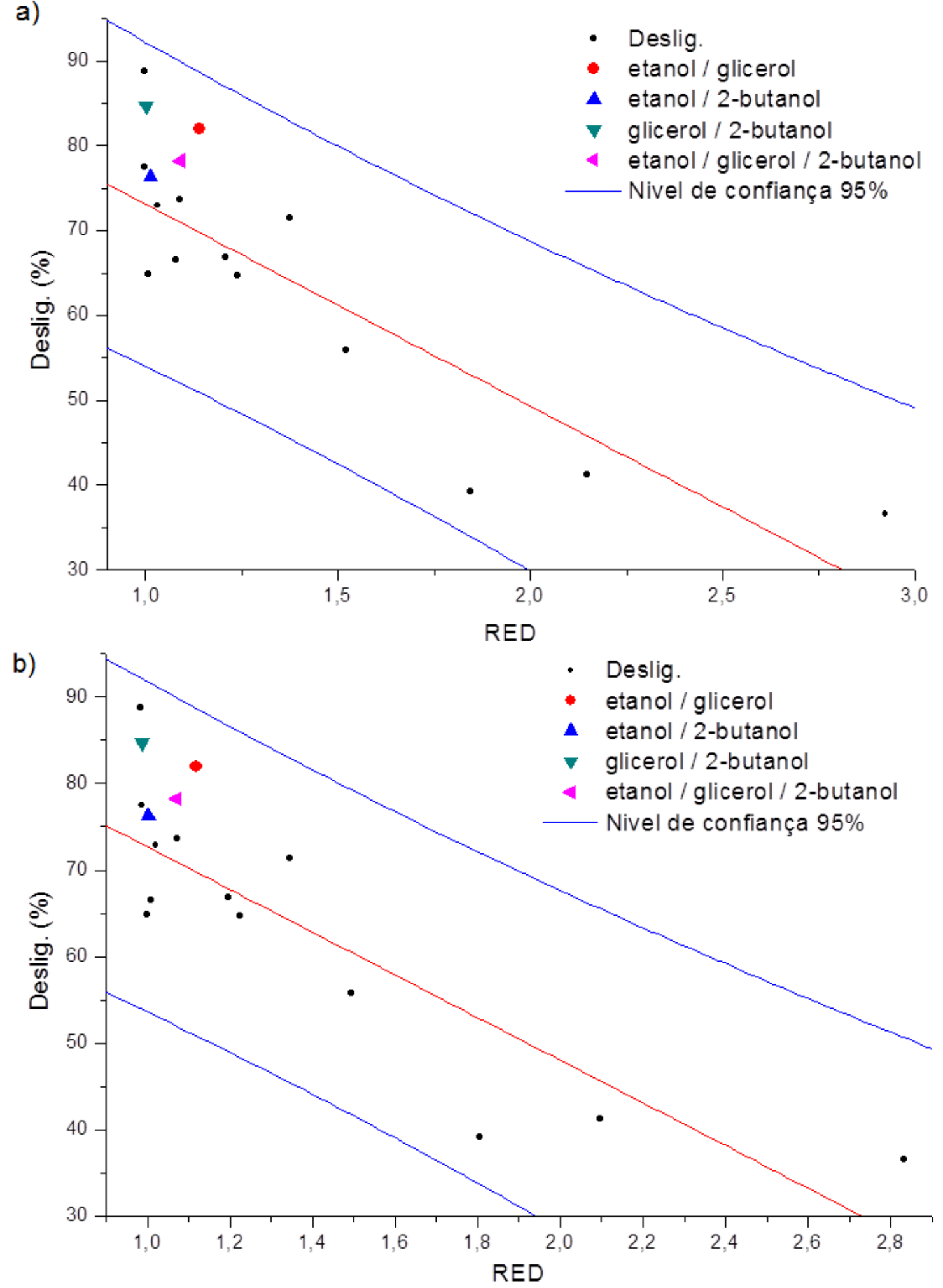
Figura 52 - Gráfico de $R_{a}$ para as misturas terciárias e a mistura quaternária em relação aos parâmetros de solubilidade da corrida 4 versus deslignificação para: a) 2-butanol imiscível em água; e b) 2-butanol miscível em água.

a)

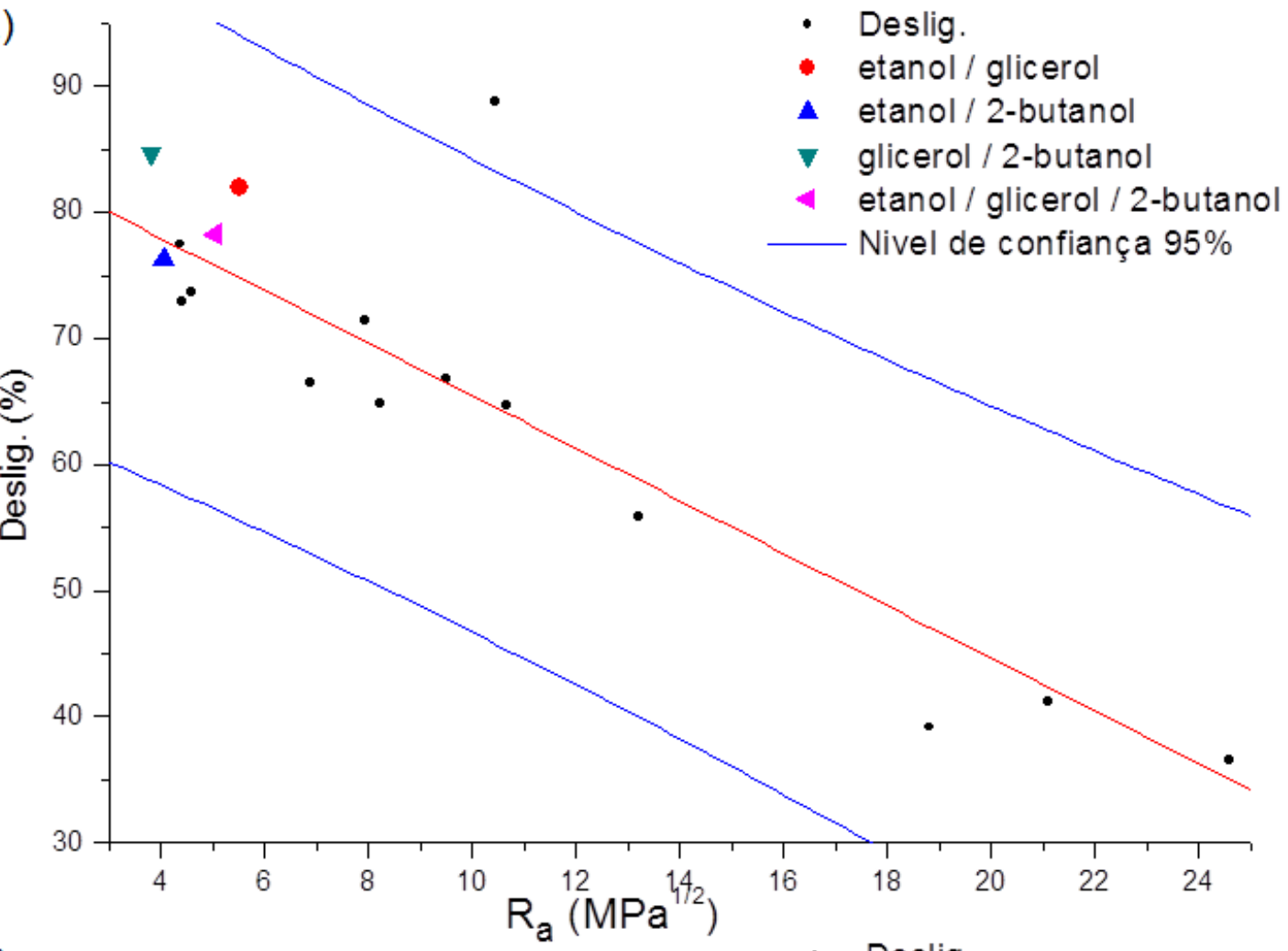

b)

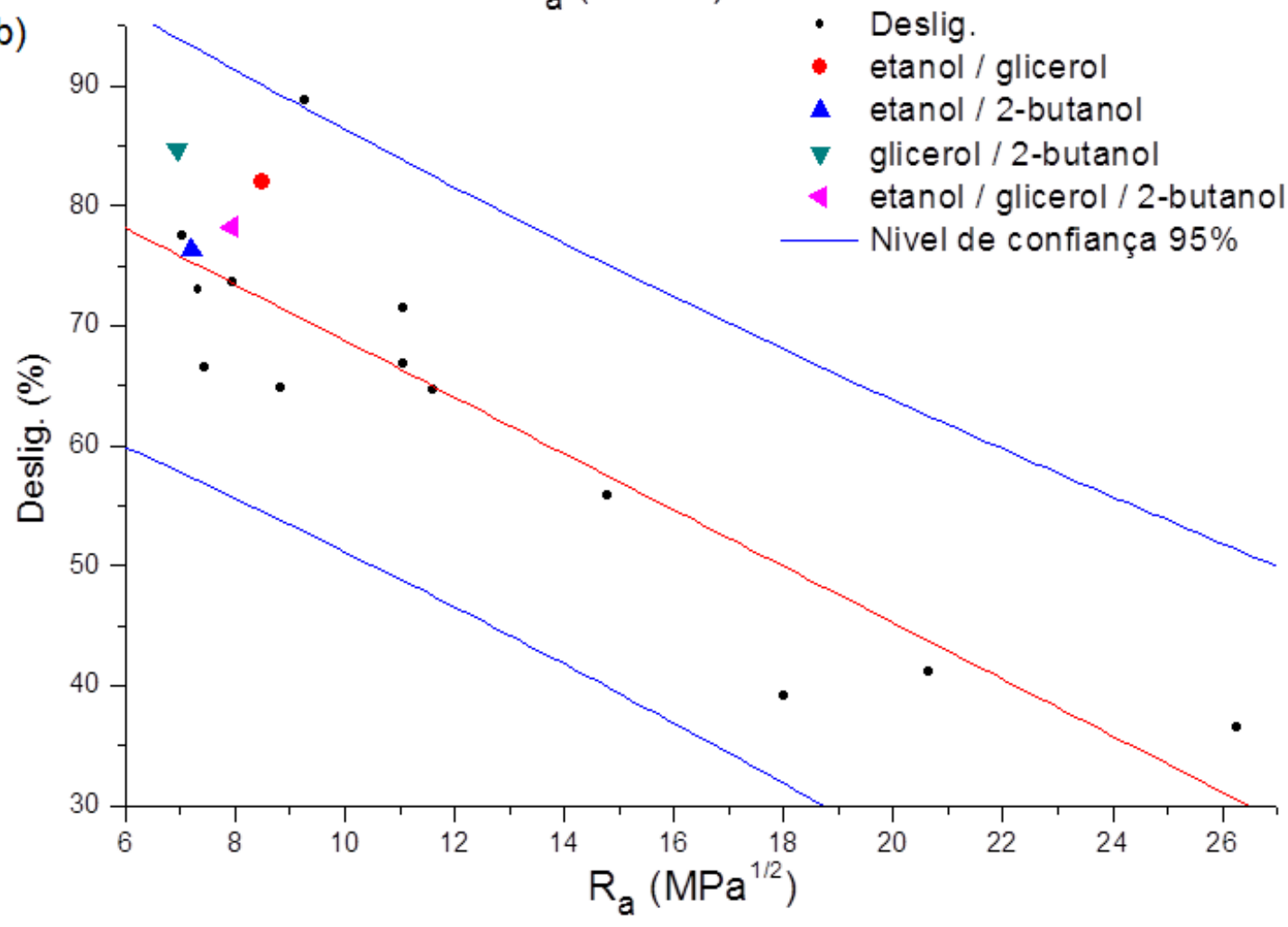


Figura 53 - Gráfico de $R E D$ para as misturas terciárias e a mistura quaternária em relação aos parâmetros de solubilidade da corrida 4 versus deslignificação para: a) 2-butanol imiscível em água; e b) 2-butanol miscível em água.
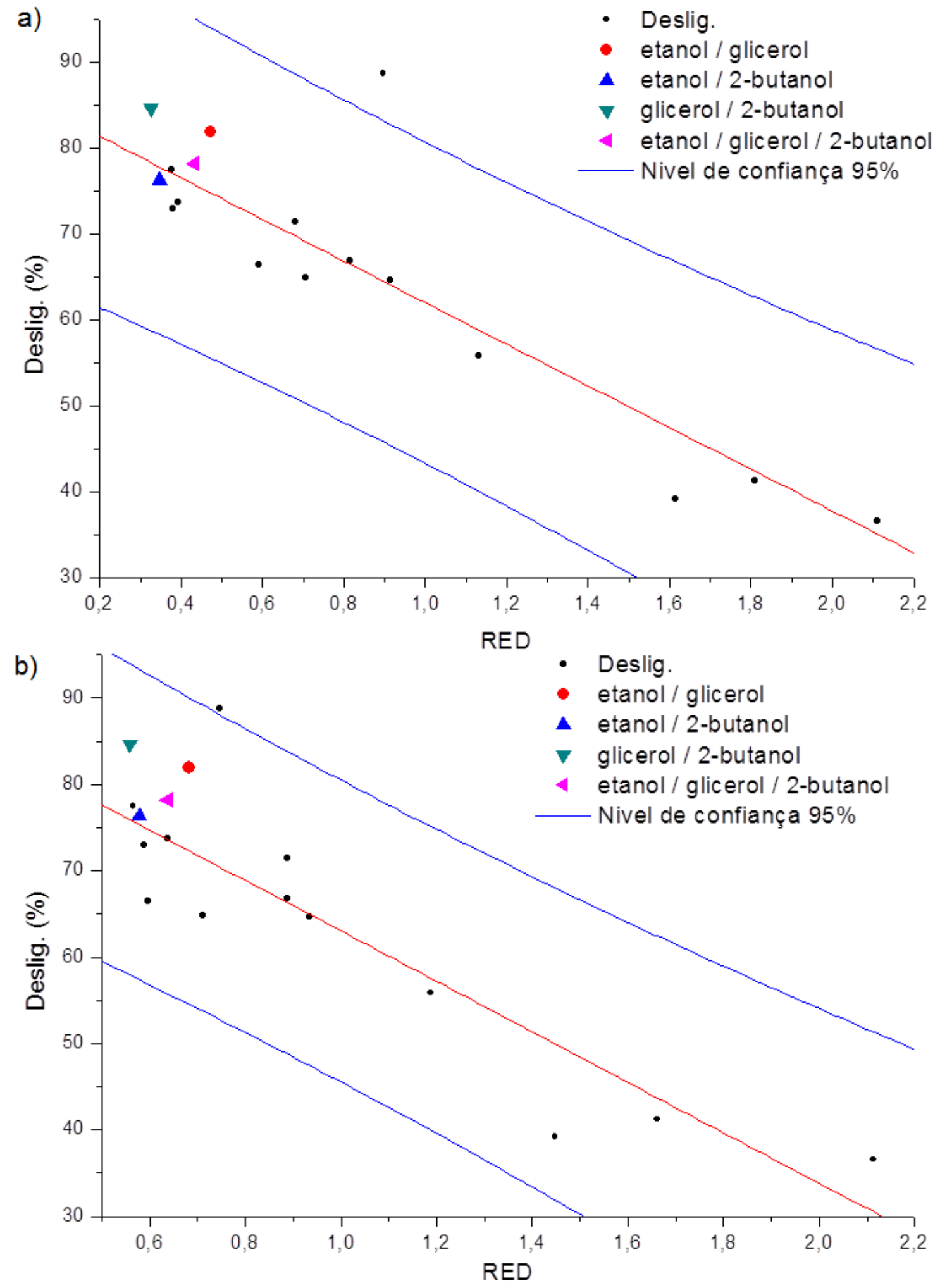
Figura 54 - Gráfico de $R_{a}$ para as misturas terciárias e a mistura quaternária em relação aos parâmetros de solubilidade da corrida 5 versus deslignificação para: a) 2-butanol imiscível em água; e b) 2-butanol miscível em água.

a)
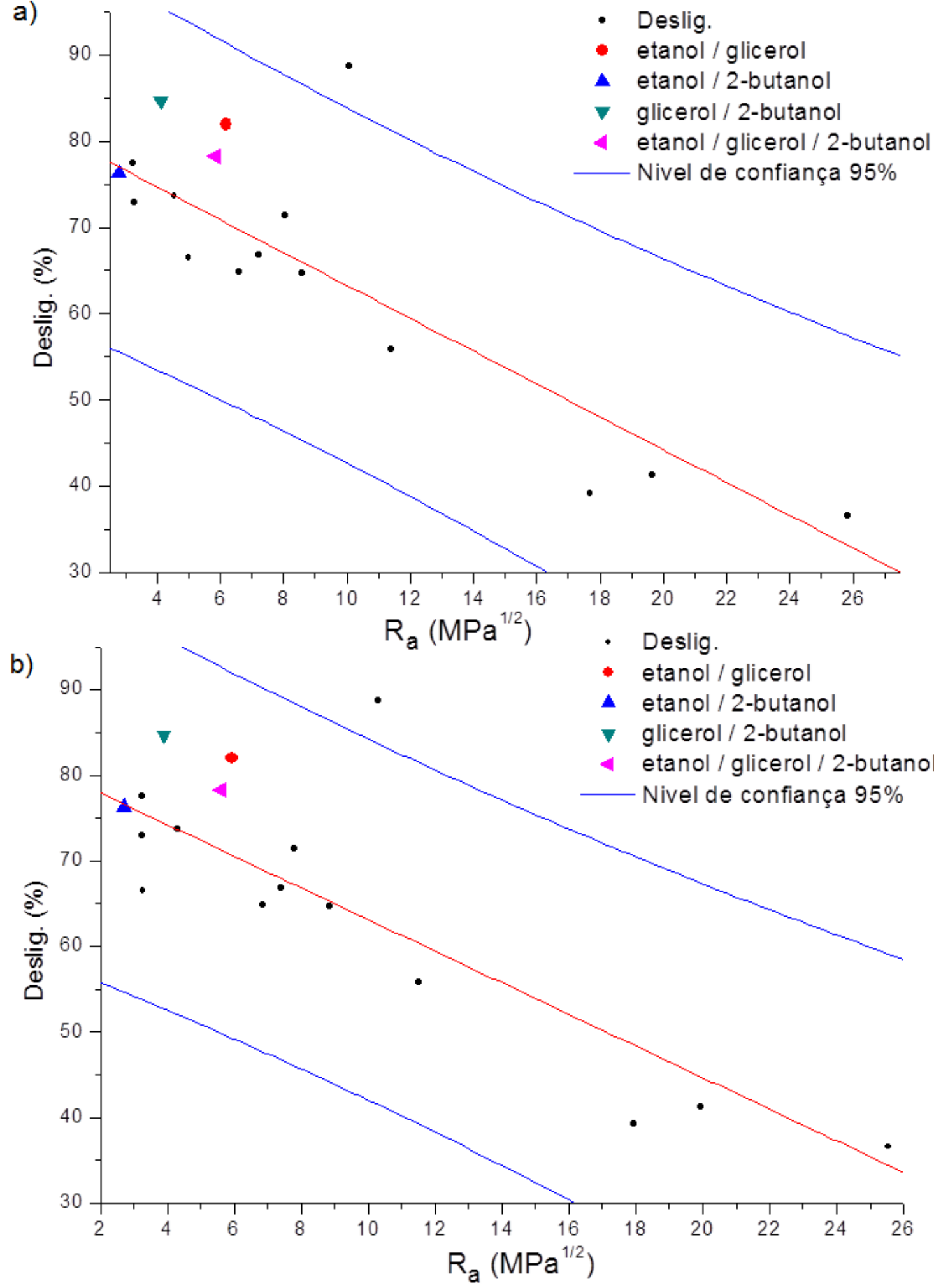
Figura 55 - Gráfico de RED para as misturas terciárias e a mistura quaternária em relação aos parâmetros de solubilidade da corrida 5 versus deslignificação para: a) 2-butanol imiscível em água; e b) 2-butanol miscível em água.

a)

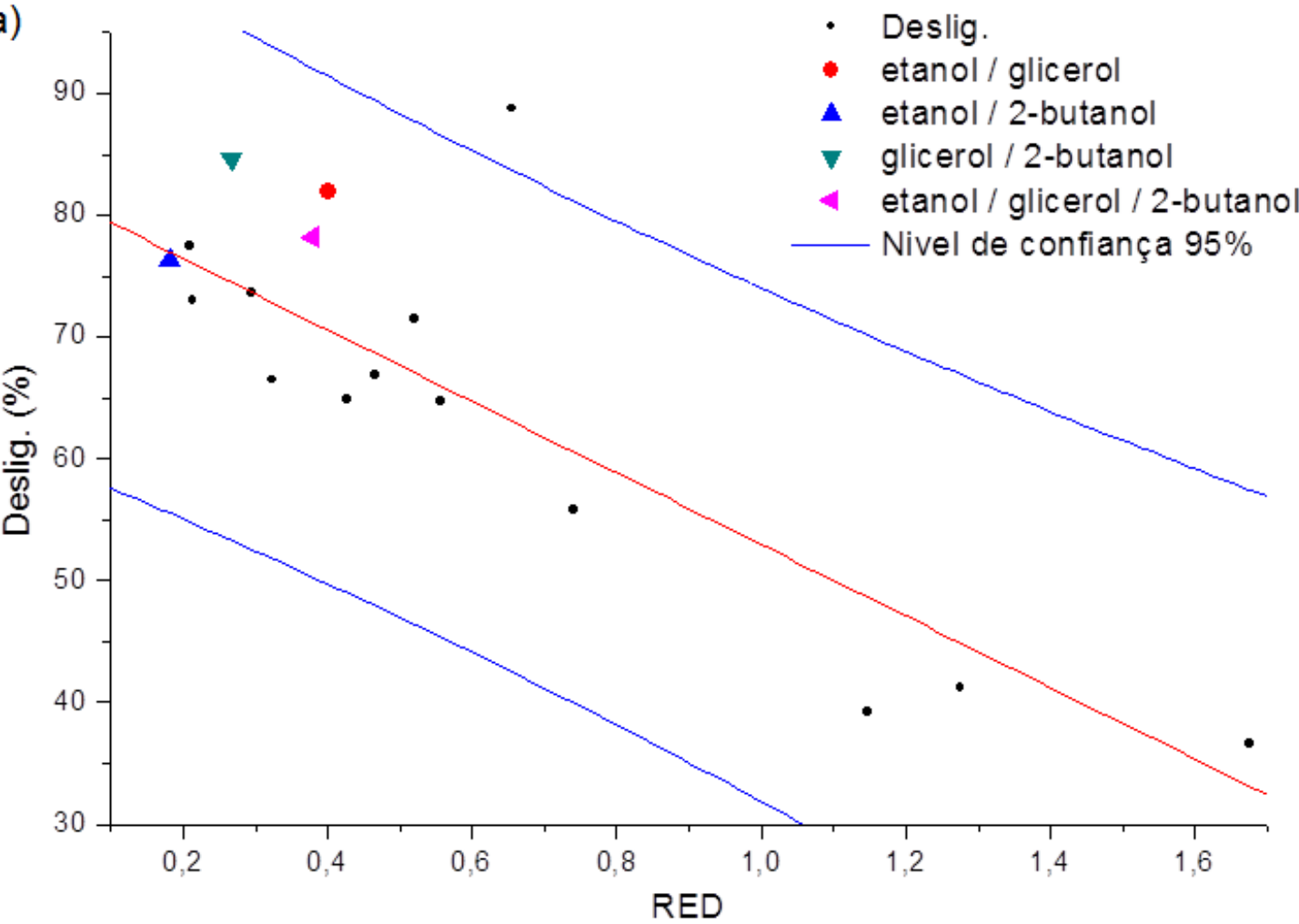

b)

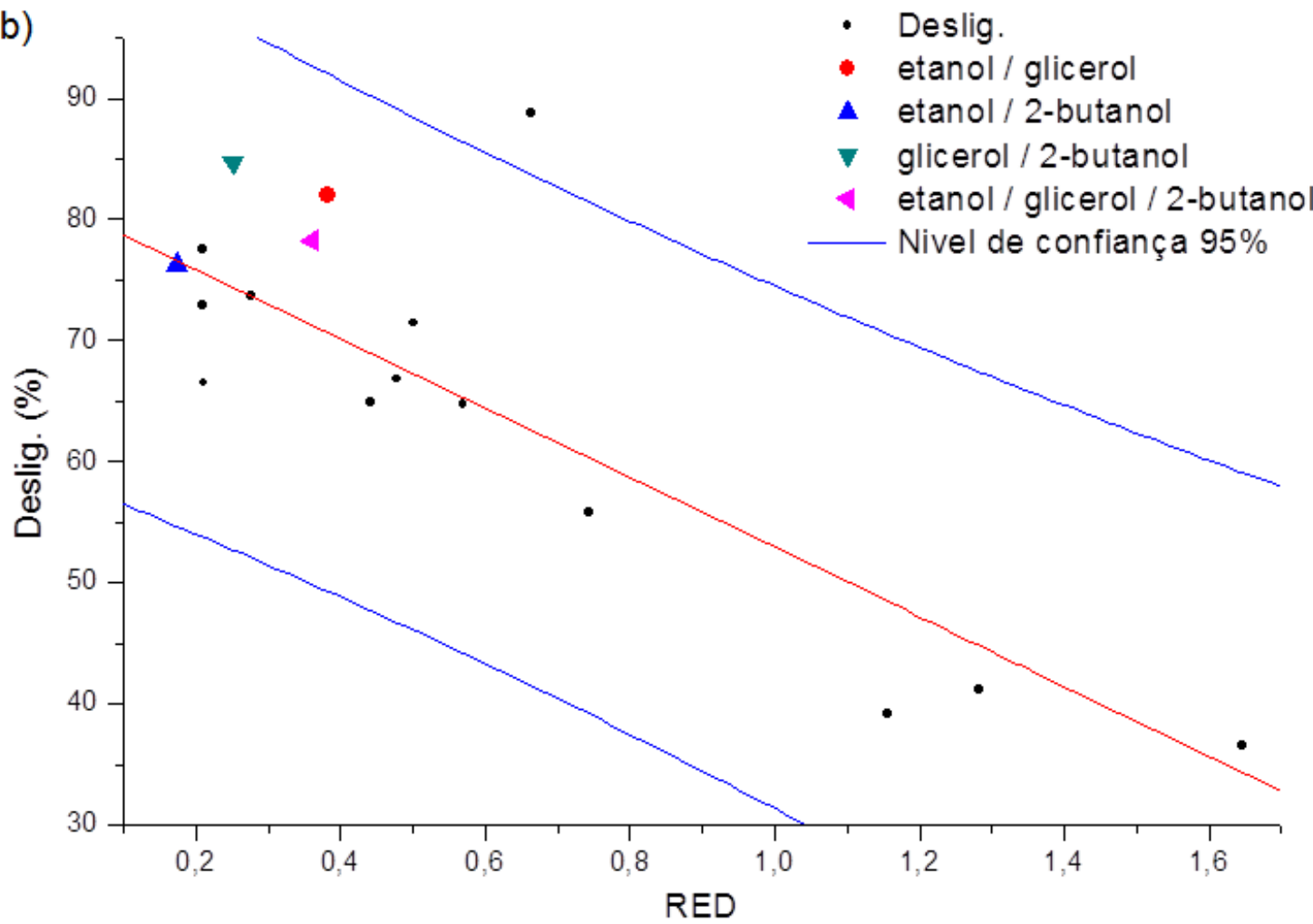

Analisando as figuras 44 a 55 verifica-se que, novamente, os novos pontos não são tão bem ajustados às regressões com relação a esfera de solubilidade da 
lignina obtida na literatura, enquanto estes são melhor ajustados nas regressões da corrida 1 para o caso de imiscibilidade do 2-butanol em água, figuras 46 "a" e 47 "a", e da corrida 2 para o caso de miscibilidade do 2-butanol em água, figuras 48 "b" e 49 "b". Verifica-se, ainda, que para o caso da imiscibilidade do 2-butanol em água o ajuste é mais adequado, isto pode ser confirmado pela figuras 56 e 57 , as quais comparam as curvas obtidas com as esferas de solubilidade da lignina das corridas com a esfera de solubilidade da lignina verificada na literatura. Para estas curvas variou-se o nível de confiança das curvas de predição para uma melhor verificação dos dados. Nesta variação, verificou-se que para a esfera de solubilidade da literatura pode-se prever todos os dados, com exceção do ponto do 1,4-dioxano, com um nível de confiança de $80 \%$, enquanto que para a esfera da corrida 1 e da corrida 2 prevê-se todos os dados, com exceção do 1,4-dioxano, com um nível de confiança de cerca de $70 \%$ e $85 \%$, respectivamente.

Figura 56 - Comparação entre distancias e afinidades entre a corrida de melhor ajuste e o dado obtido na literatura, para 2-butanol imiscível em água: a) $R_{a}$ Literatura; b) $R E D$ Literatura; c) $R_{a}$ corrida 1 ; d) $R E D$ corrida 1 .
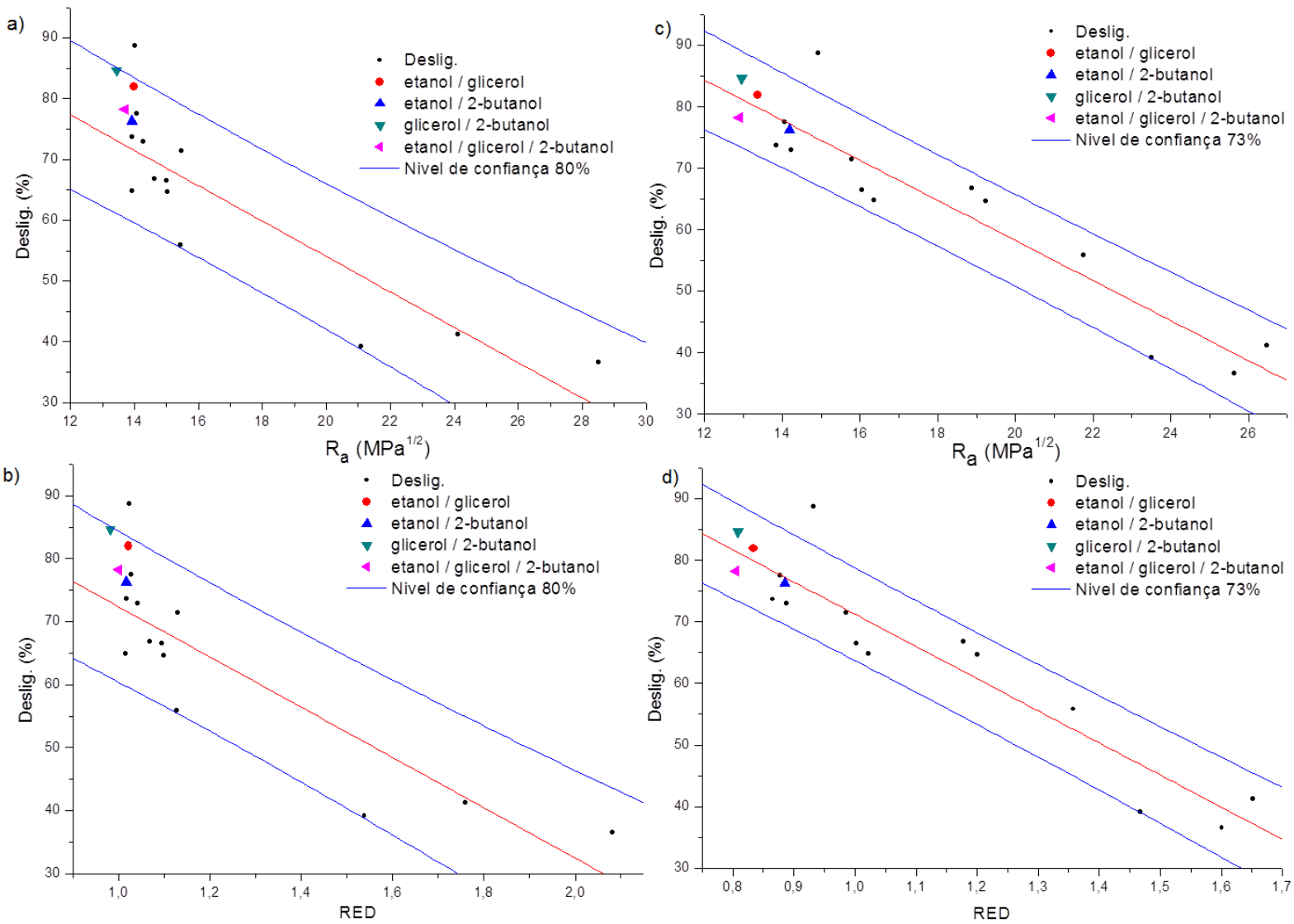
Figura 57 - Comparação entre distancias e afinidades entre a corrida de melhor ajuste e o dado obtido na literatura, para 2-butanol miscível em água: a) $R_{a}$ Literatura; b) $R E D$ Literatura; c) $R_{a}$ corrida 2 ; d) RED corrida 2.
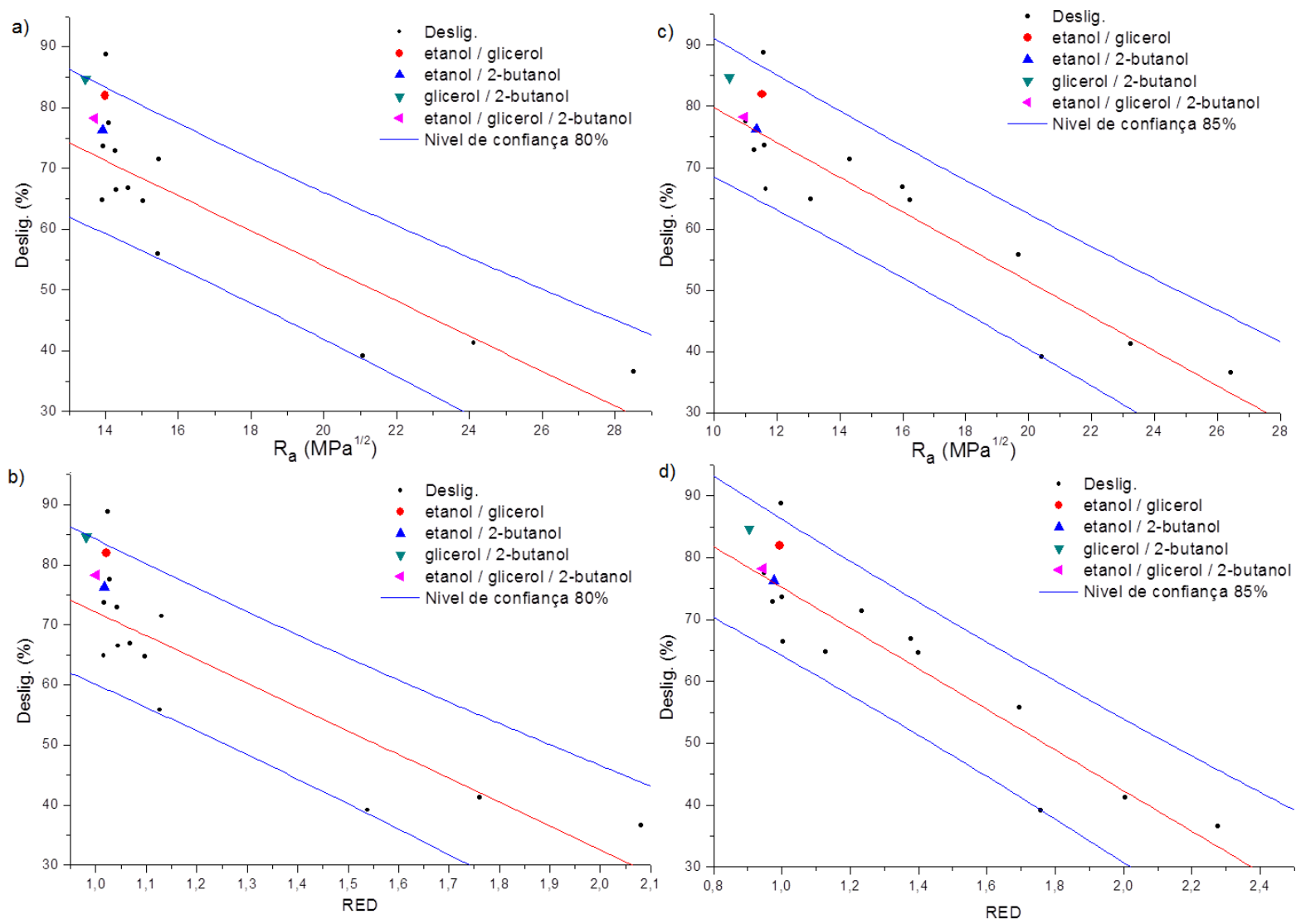

Com exceção do resultado da reação de deslignificação com o 1,4-dioxano, verifica-se que para o melhor ajuste dos dados apenas com um nível de confiança de $73 \%$ consegue-se prever todos os dados, o que corresponde a algo próximo de um desvio padrão em relação à média. Assim, pode-se concluir que deve-se considerar o 2-butanol com sendo imiscível em água, para se explicar o seu comportamento.

Em todos os gráficos que relacionam distancia e afinidade com a deslignificação, figuras 30, 31, 33 a 42 e 44 a 55, verifica-se que o comportamento do 1,4-dioxano é diferenciado em relação ao dos outros solventes, visto que este sempre está muito distante das regressões lineares. Isto ocorre devido ao elevado grau de deslignificação que este solvente permite alcançar, associado a resultados de rendimento de reação bem elevados, ou seja, obtêm-se baixos valores de lignina insolúvel nas polpas e um rendimento elevado, o que resulta em um valor de deslignificação tão elevado. Desta forma, pode-se sugerir que para a obtenção de valores mais apropriados para a elaboração dos dados é necessário alguma 
correção ligada à remoção das outras frações da biomassa, as hemiceluloses e a celulose.

Os pontos referentes às misturas de solventes orgânicos foram acrescentados aos obtidos anteriormente e obteve-se novas regressões lineares para as distancias e para a afinidade com relação ao centro da esfera de solubilidade da lignina da corrida 1, observadas nas figuras 65 e 66, somente considerando o 2-butanol com sendo imiscível em água. Observa-se nestas figuras que houve pouca variação em relação aos coeficientes lineares e angulares, ou seja, a nova regressão é muito similar a produzida anteriormente, o que indica que de fato os pontos adicionados estão bem ajustados. Contudo, apesar da similaridade observa-se um aumento no valor de $\mathrm{R}^{2}$, isto ocorre, pois, neste novo caso há mais pontos melhor ajustados à nova regressão do que anteriormente.

Figura 58 - Distancias entre os solventes e o centro da melhor esfera de solubilidade da lignina versus deslignificação.
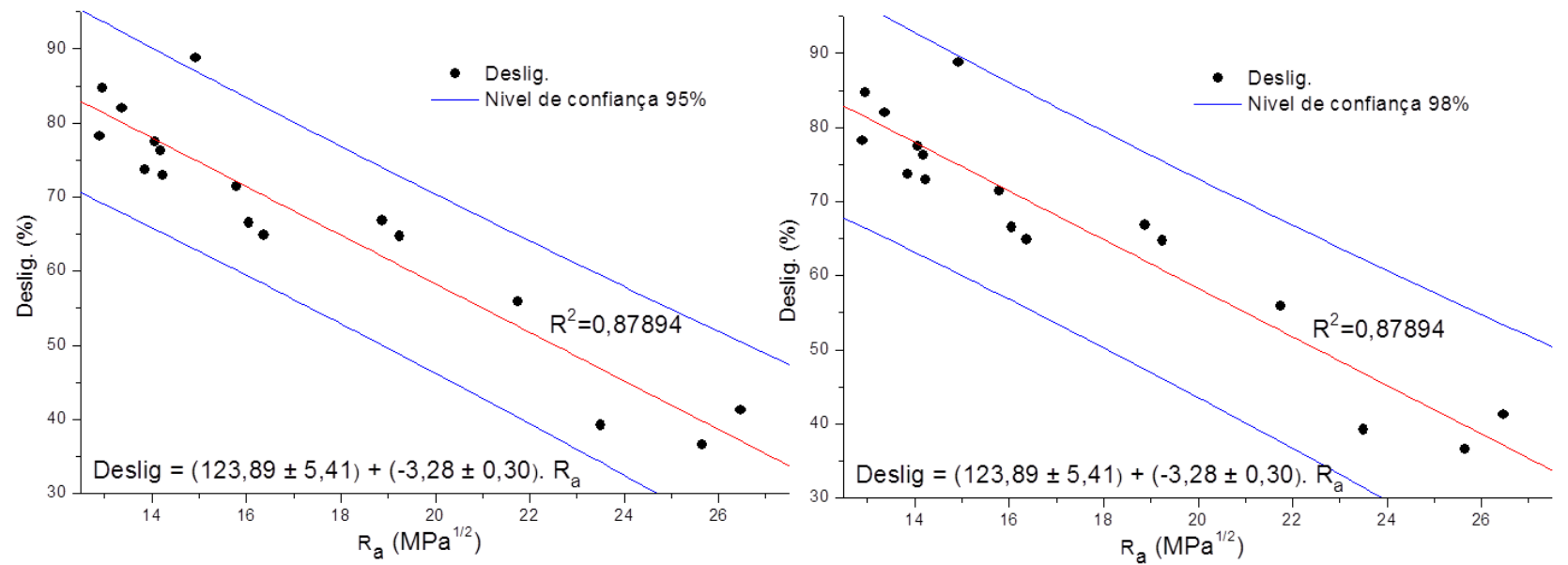

Figura 59 - Afinidade entre os solventes e o centro da melhor esfera de solubilidade da lignina versus deslignificação.
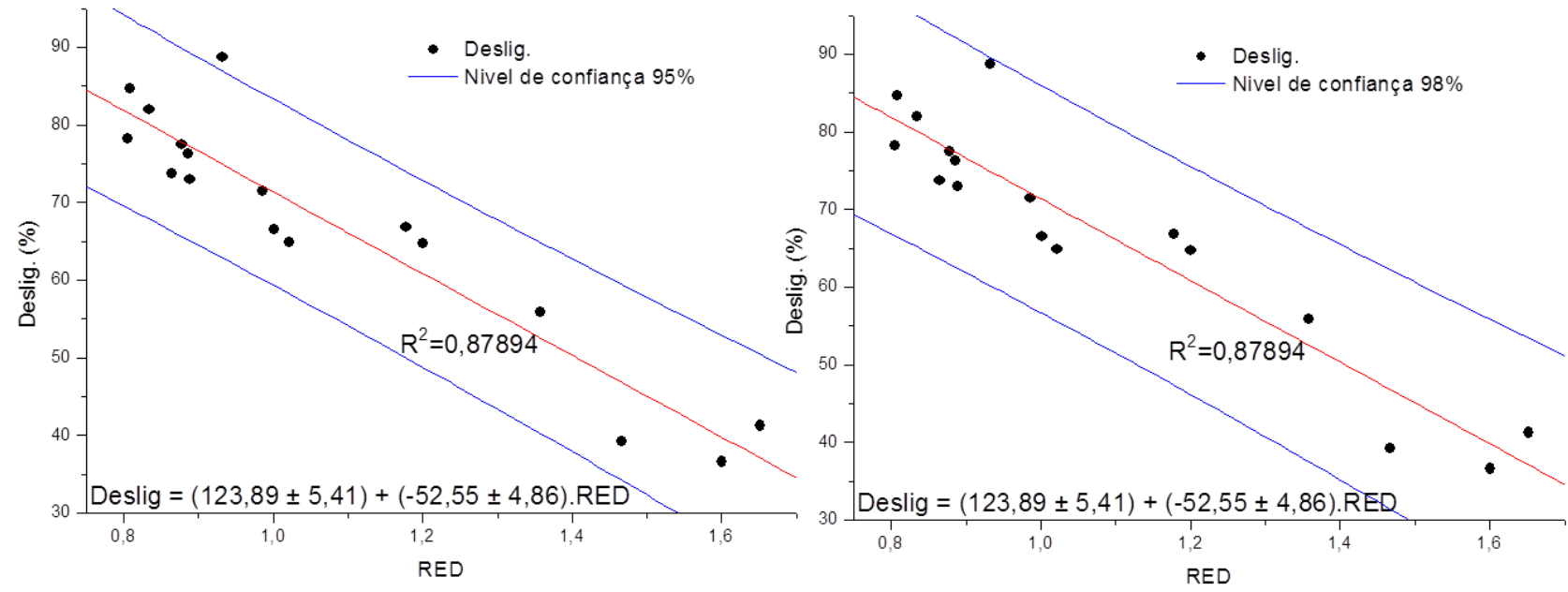
Ademais, nas figuras 58 e 59, observa-se em conjunto uma aproximação das curvas de previsão para um nível de confiança de $95 \%$, visto que houve uma diminuição no desvio do coeficiente angular.

Como resultado da aproximação das curvas de predição de nível de confiança de $95 \%$, observa-se que o ponto referente ao 1,4-dioxano não está dentro da faixa de probabilidade de dois desvios padrão, 95\%, e sim, no limiar da faixa correspondente a cerca de dois e meio desvios padrão, $98 \%$. Desta forma, pode-se considerar que o ponto do 1,4-dioxano não pertence ao conjunto de dados e pode ser excluído, como indicado nas figuras 60 e 61 . Esta exclusão não indica que houve erro na realização da reação de deslignificação e sim, que o comportamento do 1,4dioxano é diferenciado dos demais solventes orgânicos, assim, para a obtenção do parâmetro de solubilidade da lignina de bagaço de cana-de-açúcar deve-se manter a solução de 1,4-dioxano com água como um dos solventes na qual a lignina é solúvel.

Figura 60 - Distancias entre os solventes e o centro da r esfera de solubilidade da corrida 1 versus deslignificação, com exclusão do 1,4-dioxano.

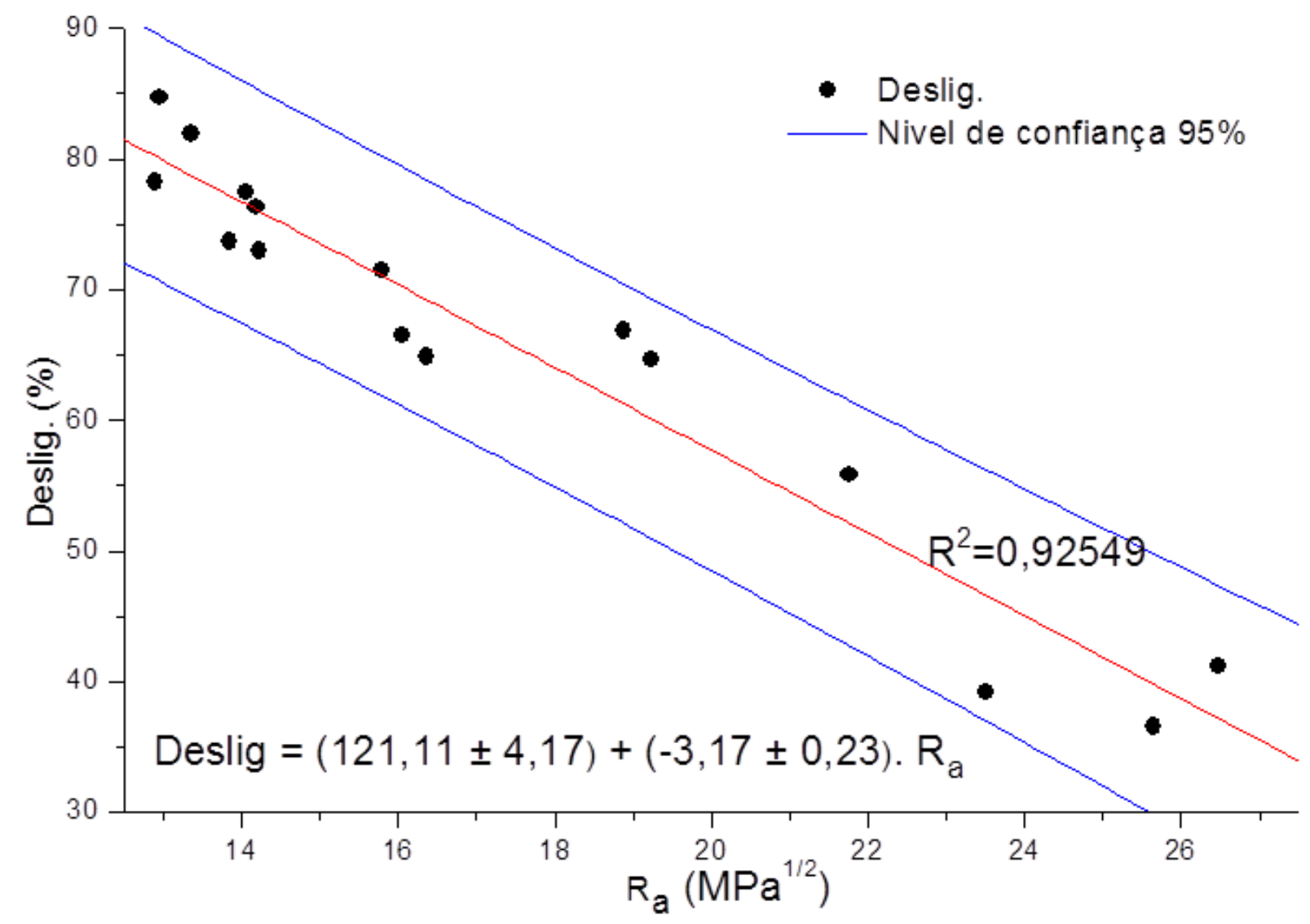


Figura 61 - Afinidades entre os solventes e o centro da esfera de solubilidade da corrida 1 versus deslignificação, com exclusão do 1,4-dioxano.

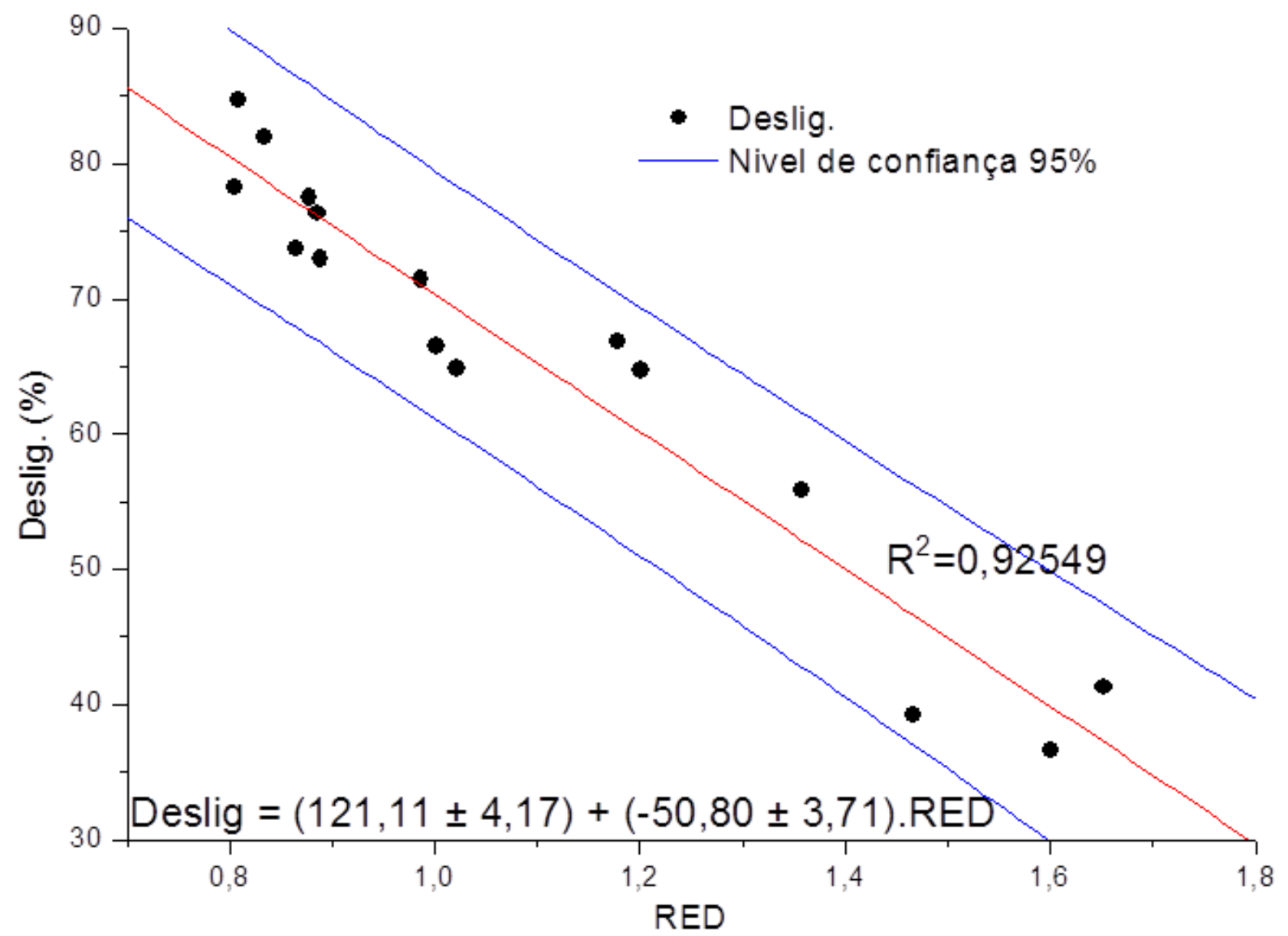

Verifica-se ainda, nas figuras 60 e 61 , que com a exclusão do dado correspondente a deslignificação com 1,4-dioxano, o ajuste da curva de regressão linear passa a ter um valor de $\mathrm{R}^{2}$ igual a 0,92549 , valor este muito aceitável, considerando as diferentes variáveis que o problema proporciona e que foram ignoradas, como a variação dos parâmetros com a temperatura, a variação de pressão nos sistemas e etc..

Observando-se as tabelas 02 e 12, que mostram os parâmetros de solubilidade de todos os solventes de polpação utilizados, pode-se verificar que 0 comportamento diferenciado para a deslignificação do 1,4-dioxano se deve ao fato deste possuir uma capacidade muito elevada de realizar interações do tipo dispersivas, ao mesmo tempo que consegue ter uma capacidade intermediária de realização de ligações de hidrogênio, enquanto que, para as demais soluções com melhor capacidade de deslignificação, formadas principalmente por estruturas com grupos hidroxila (etanol, 1-butanol, 2-butanol, isopropanol, metanol e glicerol), a aproximação do centro da esfera de solubilidade da lignina ocorre pela capacidade elevada de realização de ligações de hidrogênio associada a valores intermediários 
para interações polares. Assim, apesar da representação da solubilidade da lignina ser uma esfera, não necessariamente a forma mais adequada para a inserção dos dados seja esta.

Desta maneira, verifica-se que para a obtenção dos parâmetros de solubilidade para um polímero é interessante testar a solubilidade com solventes com características diferentes, porém, para relacionar as distâncias e afinidade deste centro de solubilidade com os diferentes solventes com algum outro parâmetro reacional da extração é interessante se possuir solventes com características semelhantes, para um melhor ajuste do modelo.

Por fim, uma ultima corrida foi realizada no programa, buscando uma "otimização" do resultado da esfera de solubilidade para a lignina, utilizando também os resultados das misturas de solventes orgânicos, além dos demais solventes (corrida 6). Esta corrida foi baseada no melhor resultado obtido anteriormente, corrida 1, considerando-se o 2-butanol como sendo imiscível em água. Nas tabelas 15 e 16 pode-se verificar a comparação entre os dados de solubilidade inseridos no programa e dos parâmetros de solubilidade da corrida 1, da corrida de otimização e da literatura, e a comparação entre as distâncias e afinidades nas corridas 1 e 6 e na literatura.

Tabela 15 - Comparação entre os dados de solubilidade inseridos no programa e dos parâmetros de solubilidade da corrida 1 , da corrida de otimização e da literatura.

\section{Solvente principal}

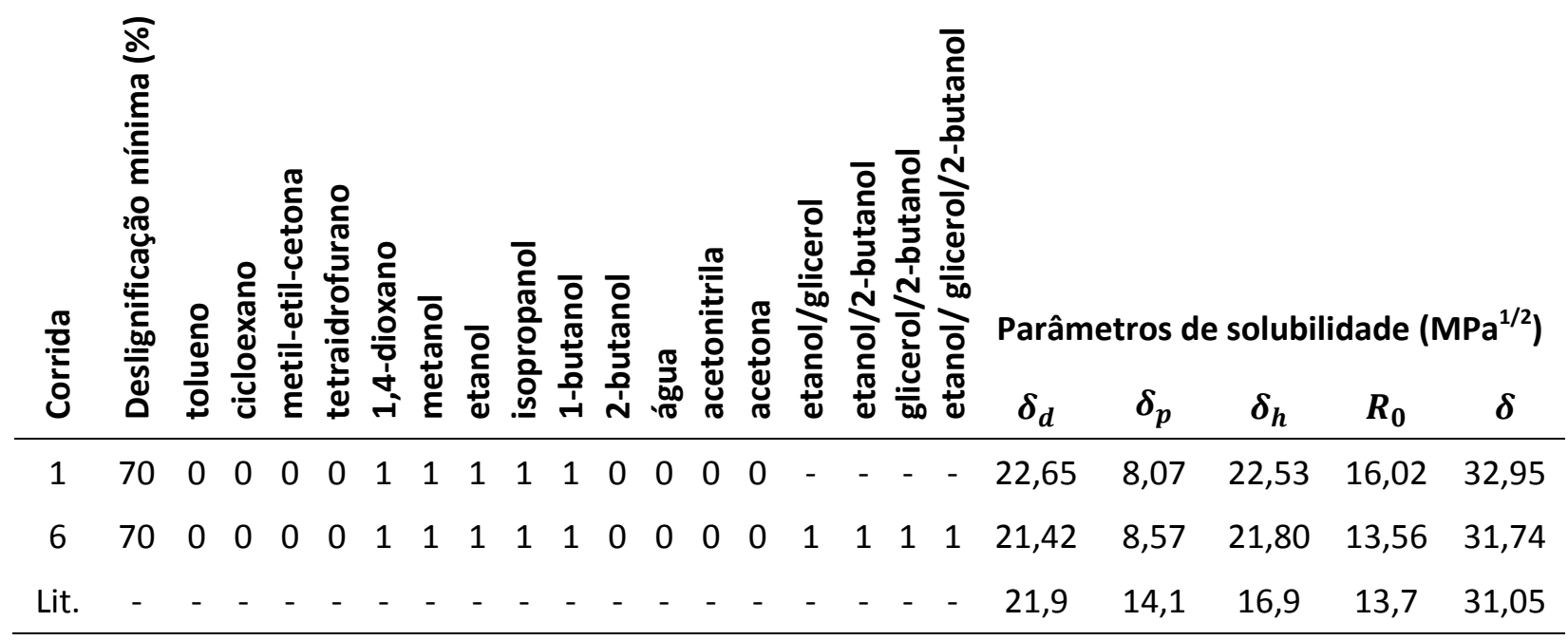


Tabela 16 - Comparação entre as distâncias e afinidades com as ligninas das corridas 1 e 6 e da literatura.

\begin{tabular}{ccccccc}
\hline \multirow{2}{*}{ Solvente principal } & \multicolumn{3}{c}{ Corrida $\mathbf{c}$} & \multicolumn{2}{c}{ Corrida $\mathbf{6}$} & \multicolumn{2}{c}{ Literatura } \\
& $\boldsymbol{R}_{\boldsymbol{a}}$ & $\boldsymbol{R} \boldsymbol{E} \boldsymbol{D}$ & $\boldsymbol{R}_{\boldsymbol{a}}$ & $\boldsymbol{R} \boldsymbol{E} \boldsymbol{D}$ & $\boldsymbol{R}_{\boldsymbol{a}}$ & $\boldsymbol{R} \boldsymbol{E} \boldsymbol{D}$ \\
\hline tolueno & 23,50 & 1,47 & 22,14 & 1,63 & 21,07 & 1,54 \\
cicloexano & 26,47 & 1,65 & 25,01 & 1,84 & 24,12 & 1,76 \\
metil-etil-cetona & 19,24 & 1,20 & 17,01 & 1,25 & 15,04 & 1,10 \\
tetraidrofurano & 16,37 & 1,02 & 14,18 & 1,05 & 13,92 & 1,02 \\
1,4-dioxano & 14,93 & 0,93 & 13,35 & 0,98 & 14,03 & 1,02 \\
metanol & 15,80 & 0,99 & 13,44 & 0,99 & 15,48 & 1,13 \\
etanol & 13,85 & 0,86 & 11,33 & 0,84 & 13,94 & 1,02 \\
isopropanol & 14,23 & 0,89 & 11,73 & 0,87 & 14,28 & 1,04 \\
1-butanol & 14,06 & 0,88 & 11,58 & 0,85 & 14,08 & 1,03 \\
2-butanol & 16,05 & 1,00 & 13,70 & 1,01 & 15,01 & 1,10 \\
água & 25,65 & 1,60 & 24,81 & 1,83 & 28,51 & 2,08 \\
acetonitrila & 21,76 & 1,36 & 19,48 & 1,44 & 15,44 & 1,13 \\
acetona & 18,88 & 1,18 & 16,50 & 1,22 & 14,63 & 1,07 \\
etanol/glicerol & 13,36 & 0,83 & 10,95 & 0,81 & 13,98 & 1,02 \\
etanol/2-butanol & 14,19 & 0,89 & 11,65 & 0,86 & 13,93 & 1,02 \\
glicerol/2-butanol & 12,96 & 0,81 & 10,44 & 0,77 & 13,45 & 0,98 \\
etanol/glicerol/2-butanol & 12,90 & 0,80 & 10,47 & 0,77 & 13,70 & 1,00 \\
\hline
\end{tabular}

Observa-se na tabela 15 que na "otimização" do parâmetro de solubilidade para a lignina de bagaço de cana-de-açúcar houve uma pequena diminuição nos valores de $\delta_{d}$ e de $\delta_{h}$, com um ligeiro aumento no valor de $\delta_{p}$ e uma grande diminuição do raio da esfera, o que é uma boa indicação de que de fato houve uma melhora dos resultados, visto que para um polímero, é sempre buscado um centro da esfera com o menor raio possível. Contudo, observa-se que pouco mudou com relação às afinidades, ou seja, o novo modelo manteve aproximadamente as mesmas características do modelo anterior.

Nas figuras 62 e 63 pode-se observar os gráficos relacionando os dados da tabela 16 como os resultados de deslignificação. Nestas figuras, observa-se que novamente o 1,4-dioxano se comporta diferentemente do restante dos solventes assim, este não foi incluído nos resultados para a realização da regressão linear dos dados. 
Figura 62 - Distancias entre os solventes e o centro da melhor esfera de solubilidade da lignina versus deslignificação, com exclusão do 1,4-dioxano

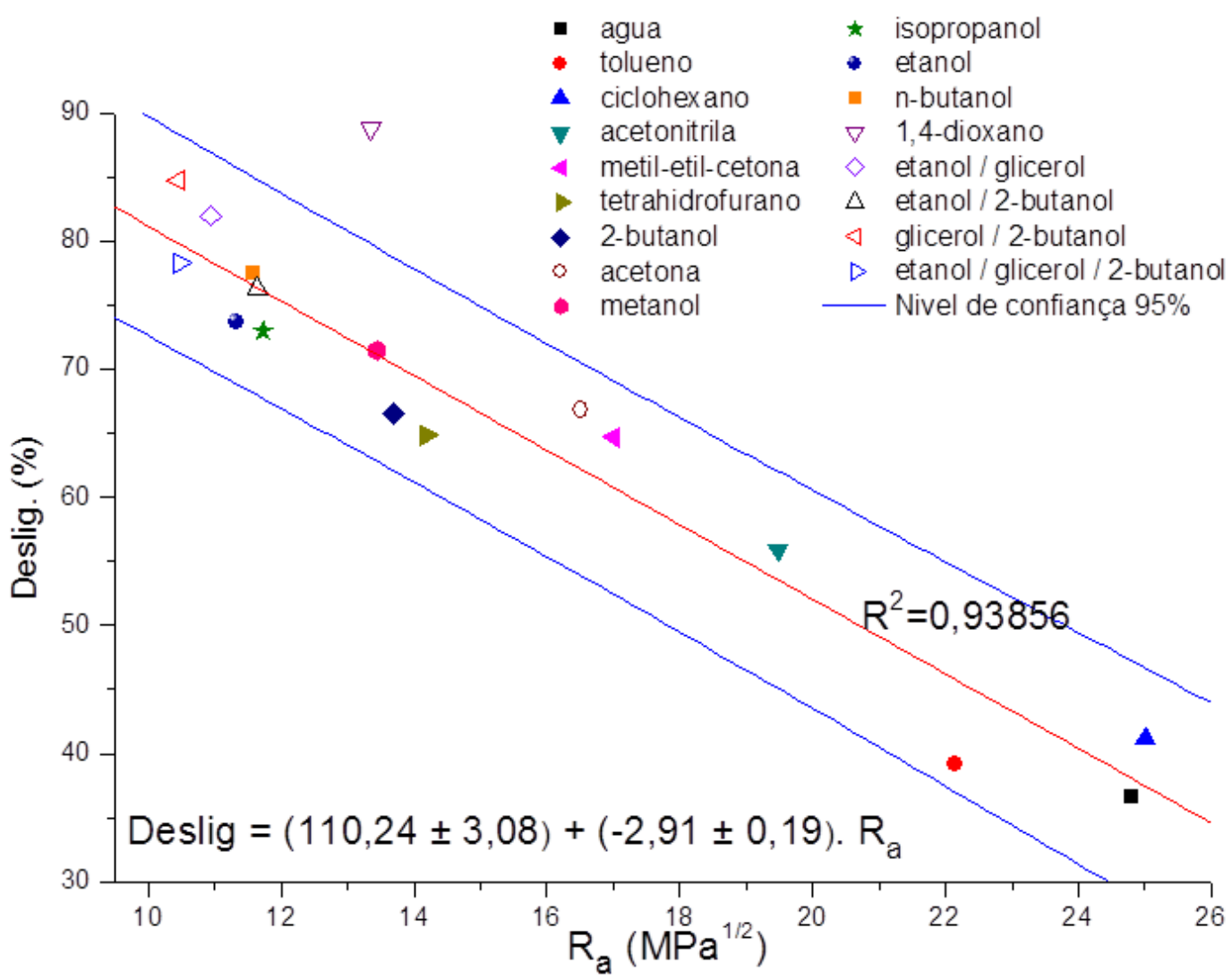

Figura 63 - Afinidades entre os solventes e o centro da melhor esfera de solubilidade da lignina versus deslignificação, com exclusão do 1,4-dioxano.

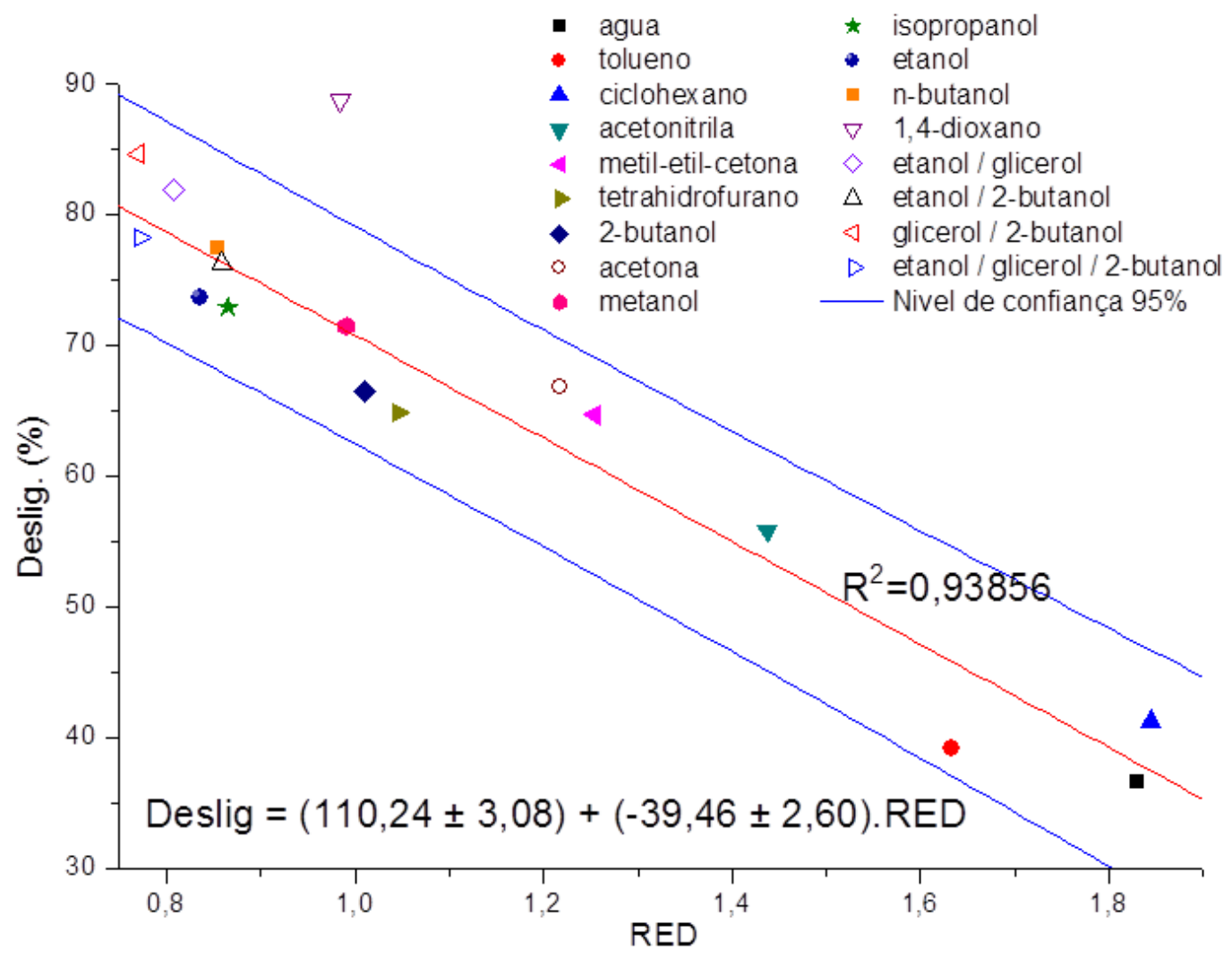


Verifica-se nas figuras 62 e 63 que o ajuste dos dados ao novo modelo ainda sofreu um pequeno ajuste, passando de $u m R^{2}$ de 0,92549 para um $R^{2}$ de 0,93856 , com uma pequena diminuição nos desvios dos coeficientes linear e angular.

Comparando-se os valores da tabela 15 para os parâmetros de solubilidade de Hansen obtidos na corrida de otimização com os valores observados na literatura, verifica-se que ambos possuem praticamente o mesmo valor para 0 parâmetro de solubilidade total ( $\delta$, obtido pela equação 9 ) e para os valores de $\delta_{d} \mathrm{e}$ de $R_{0}$, contudo possuem uma grande diferença nos valores de $\delta_{p}$ e de $\delta_{h}$. Enquanto que na esfera de solubilidade da lignina observada na literatura os parâmetros de solubilidade para interações polares e para a ligação de hidrogênio possuem valores intermediários (14,1 e 16,9 $\mathrm{MPa}^{1 / 2}$, respectivamente), na esfera de solubilidade obtida na corrida de otimização, observa-se um valor mais baixo para $\delta_{p}$ e um valor superior para $\delta_{h}$ (8,57 e 21,80 $\mathrm{MPa}^{1 / 2}$, respectivamente), ou seja, uma característica não tão polar, porém, com uma capacidade de realização de ligações de hidrogênio elevada (similar à do metanol puro).

\subsection{CONSIDERACÕESS FINAIS}

Apesar da observação de um ajuste mais apropriado dos dados de deslignificação com relação à distância e à afinidade dos licores de reação a esfera de solubilidade da lignina obtidos na corrida de otimização, não se pode afirmar com certeza que os valores dos parâmetros de solubilidade de Hansen para a lignina correspondem a estes e não os obtidos por Hansen e Björkman (1998). Assim, pode-se afirmar somente, que o parâmetro de solubilidade obtido por este trabalho permite uma correlação dos dados de deslignificação nas condições estudadas, para o tipo de solventes utilizados. Ademais, deve-se considerar que a obtenção de um parâmetro de solubilidade para uma substância com a complexidade observada na lignina, com as diferentes possibilidades de ligação química e de ordenação dos monômeros, é muito difícil, primeiro porque na estrutura nativa este composto praticamente não é solúvel em nenhum solvente, já que possui uma massa molar muito elevada, e em segundo porque para a realização dos testes de solubilidade 
clássicos (como por exemplo, a verificação do inchamento do polímero em cada solvente) seria necessário se possuir uma lignina isolada, o que não acontece na estrutura nativa que está interligada às outras frações da biomassa lignocelulósica (ou por ligações químicas ou por interações intermoleculares), assim, no processo de isolamento da lignina alterações ocorrem tanto no tamanho quanto na estrutura da lignina.

Outro característica observada nos parâmetros de solubilidade de Hansen para a lignina, tanto os obtidos neste trabalho quanto os verificado na literatura, são os valores dos parâmetros de solubilidade totais, que deveriam corresponder ao parâmetro de solubilidade de Hildebrand. Verifica-se que estes valores, obtidos a partir dos parâmetros de solubilidade de Hansen, tabela 15, são muito superiores aos valores encontrados anteriormente por Schuerch (1952) para o parametro de solubilidade de Hildebrand da lignina. Contudo, Schuerch (1952) observou que um aumento na capacidade de realização de ligações de hidrogênio, com solventes dentro da faixa de parametros de solubilidade de 20-23 $\mathrm{MPa}^{1 / 2}$, levava a um aumento na solubilidade da lignina. Isto também foi observado neste trabalho, visto que a esfera de solubilidade para a lignina obtida possui um valor mais elevado de $\delta_{h}$ do que a esfera descrita na literatura.

Observando-se os valores dos parâmetros de solubilidade de Hansen para o 1,4-dioxano e a deslignificação proporcionada por este, em comparação com os demais licores de polpação, verifica-se que o parâmetro de solubilidade $\delta_{d}$ é um fator muito importante na solubilização da lignina, além da simples distância ou afinidade de um solvente com a esfera de lignina. Assim, provavelmente, outro solvente que possuísse praticamente o mesmo valor de $R E D$ do etanol, por exemplo, mas que possuísse um valor mais elevado de $\delta_{d}$, levaria a uma extensão de deslignificação superior. 


\section{CONCLUSÃO}

Considerando-se o objetivo descrito anteriormente, de aplicar o conceito de parâmetros de solubilidade de Hansen à deslignificação organossolve de bagaço de cana-de-açúcar, concluiu-se que o parâmetro de solubilidade de Hildebrand dos solventes não é um parâmetro que permite explicar efetivamente a relação da solubilidade com as extensões da reação de deslignificação, para alguns solventes, pois não diferencia o tipo de interações que cada solvente pode realizar com a lignina. Desta maneira, os parâmetros de Hansen foram testados, e concluiu-se que estes podem descrever a relação entre a deslignificação organossolve nas condições utilizadas e as distâncias e afinidades entre os solventes e o centro da esfera de solubilidade da lignina.

Concluiu-se também, que os parâmetros de solubilidade de Hansen obtidos na literatura para a lignina, e as distancias e afinidades correspondentes dos solventes, não permitem um ajuste linear dos dados de deslignificação e que outra esfera de solubilidade para a lignina deveria ser elaborada.

Obteve-se uma esfera de solubilidade para a lignina que permitiu o ajuste dos dados com um coeficiente de determinação da regressão linear de 0,93856, com a exclusão do dado do 1,4-dioxano. Para esta esfera de solubilidade, verificou-se que os valores de $\delta_{d}, \delta_{p}$ e $\delta_{h}$ são relacionados a outros trabalhos publicados anteriormente e que o valor de $\delta$ desta esfera é muito próximo ao valor obtido por Hansen e Björkman (1998), apesar de ambos serem distantes do valor obtido por Schuerch (1952) para o parâmetro de solubilidade de Hildebrand para a lignina.

Ademais, concluiu-se que para a obtenção dos parâmetros de solubilidade de Hansen para a lignina é necessário considerar-se que o 2-butanol é imiscível em água e que apesar da similaridade estrutural deste solvente com o 1-butanol, a distância com relação ao centro da esfera obtida para a lignina é superior ao valor do raio da esfera, ou seja, este solvente está fora da esfera de solubilidade da lignina, enquanto que o 1-butanol, por ser solúvel em água, ocorre a aproximação do mesmo ao centro da esfera da lignina e, assim, este se apresenta contido na mesma, justificando-se desta maneira a diferença nos valores de deslignificação destes solventes. 
Com o resultado obtido para a mistura de 1,4-dioxano com água, concluiu-se que, provavelmente, o volume delimitado pelos bons solventes mais adequado não é uma esfera, e que dependendo da posição de aproximação do centro da lignina o comportamento da deslignificação pode variar.

Por fim, concluiu-se que apesar da obtenção de um parâmetro de solubilidade para a lignina que ajustasse melhor os dados de deslignificação, não se pode afirmar com certeza que esta seja a esfera de solubilidade real para a lignina, visto que para a verificação disto é necessário realizar processos de isolamento da lignina, que por sua vez promovem modificações na estrutura e no tamanho das moléculas. 


\section{REFERÊNCIAS BIBLIOGRÁFICAS}

AZIZ, S.; SARKANEN, K. Organosolv pulping - a review. Tappi Journal, v. 72, n. 3, p. $169-175,1989$.

BALOGH, D. T. Efeito do solvente na obtenção de ligninas pelo processo organossolv. 1989. 110 f. Dissertação (Mestrado) - Instituto de Química de São Carlos, Univeridade de São Paulo, São Carlos, 1989.

BALOGH, D. T.; CURVELO, A. A. S.; DE GROOTE, R. A. M. C. Solvent effects on organosolv lignin from Pinus caribaea hondurensis. Holzforschung, v. 46, n. 4, p.343-348, 1992.

BARTON, A. Solubility parameters. Chemical Reviews, v. 75, n. 6, p. 731-753, 1975.

BARTON, A. Handbook of solubility parameters and other cohesion parameters. Boca Raton: CRC, 1983. 594 p.

BASTOS, V. D. Etanol, alcoolquímica e biorrefinarias. BNDES Setorial, v. 25, p. 538, 2007.

BELGACEM, M. N.; GANDINI, A. Monomers, polymers and composites from renewable resources. Amsterdam: Elsevier, 2008. 552 p.

BIELICKA-DASZKIEWICZ, K.; VOELKEL, A.; PIETRZYŃSKA, M.; HÉBERGER, K. Role of Hansen solubility parameters in solid phase extraction. Journal of Chromatography A, v. 1217, n. 35, p. 5564-5570, 2010.

BNDES; CGEE. Bioetanol de cana-de-açúcar: energia para o desenvolvimento sustentável. Rio de Janeiro: BNDES, 2008. 316 p.

BONDI, A. Van der Waals volumes and radii. The Journal of Physical Chemistry, v. 68 , n. 3, p. $441-451,1964$. 
CANDIDO, M.; NEIVA, J. N. M.; PIMENTEL, J. C. N.; VASCONCELOS, V. R.; SAMPAIO, E. M. NETO, J. M. Evaluation of the nutritive value of sugarcane bagasse ammoniated with urea. Revista Brasileira De Zootecnia, v. 28, n. 5, p. 928-935, 1999.

CARVALHEIRO, F.; DUARTE, L.; GIRIO, F. Hemicellulose biorefineries: a review on biomass pretreatments. Journal of Scientific \& Industrial Research, p. 849-864, 2008.

CRC handbook of chemistry and physics. Online Version. Cleveland: CRC Press Online, 2011. 2656 p.

CURVELO, A. A. D. S. Processo de deslignificação organossolve. 1992. 94 f. Tese (Livre Docência) - Instituto de Física e Química de São Carlos, Universidade de São Paulo, São Carlos, 1992.

DEMIRBAŞ, A. Aqueous glycerol delignification of wood chips and ground wood. Bioresource Technology, v. 63, n. 2, p. 179-185, 1998.

EK, M.; GELLERSTEDT, G.; HENRIKSSON, G. Wood chemistry and wood biotechnology. Berlin: W. de Gruyter, 2009. 308 p.

EVTUGUIN, D.; NETO, C. P.; SILVA, A. M. S.; DOMINGUES, P. M.; AMADO, F. M. L.; ROBERT, D.; FAIX, O. Comprehensive study on the chemical structure of dioxane lignin from plantation Eucalyptus globulus wood. Journal of Agricultural and Food Chemistry, v. 49, n. 9, p. 4252-4261, 2001.

FENGEL, D.; WEGENER, G. Wood: chemistry, ultrastructure, reactions. Berlin: W. de Gruyter, 1984. 613 p.

FREISER, H. Relevance of solubility parameter in ion association extraction systems. Analytical Chemistry, v. 41, n. 10, p. 1354-1355, 1969.

GEORG, I. C. Modelagem e simulação da polpação Kraft antraquinona. 2000. 95 f. Dissertação de Mestrado em Engenharia química - Universidade Federal de Santa Catarina, Florianópolis, 2000.

GHARAGHEIZI, F. New procedure to calculate the Hansen solubility parameters of polymers. Journal of Applied Polymer Science, v. 103, n. 1, p. 31-36, 2007. 
GOLDSCHIMID, O. Ultraviolet spectra. In: SARKANEN, K. V.; LUDWIG, C. H. (Ed.). Lignins: occurrence, formation, structure and reactions. New York: John Wiley, 1971. v. 10, p. 241-266.

GUILLÉN, M. D.; BLANCO, C. G. Empirical multiparametric relationships between coal tar pitch extraction yields in organic solvents and solubility parameter components of the solvents. Fuel, v. 71, n. 3, p. 295-297, 1992.

GURGEL, L. V. A. Mecerização e modificação química de celulose e bagaço de cana-de-açúcar com anidrido succínico e trietilenotetramina: preparação de novos materiais quelantes para a adsorção de $\mathrm{Pb}(\mathrm{II}), \mathrm{Cd}(\mathrm{II}), \mathrm{Cr}(\mathrm{VI})$ e $\mathrm{Cu}(\mathrm{II}) .2007$. 180 f. Dissertação (Mestrado em Engenharia Ambiental) - Instituto de Ciências Exatas e Biológicas, Universidade Federal de Ouro Preto, Ouro Preto, 2007.

HANSEN, C. M. The three dimensional solubility parameter - Key to paint component affinities: I. Solvents, plasticizers, polymers, and resins. Journal of Paint Technology, v. 39, n. 505, p. 104-117, 1967 a.

HANSEN, C. M. The three dimensional solubility parameter - Key to paint component affinities: II. dyes, emulsifiers, mutual solubility and compatibility, and pigments. Journal of Paint Technology, v. 39, n. 511, p. 505-510, $1967 \mathrm{~b}$.

HANSEN, C. M. Hansen solubility parameters: a user's handbook. Boca Raton: CRC Press, 2007. 519 p.

HANSEN, C. M.; BJORKMAN, A. The ultrastructure of wood from a solubility parameter point of view. Holzforschung, v. 52, n. 4, p. 335-344, 1998.

HANSEN, C. M.; SKAARUP, K. The three dimensional solubility parameter - Key to paint component affinities: III. Independent calculation of the parameter components. Journal of Paint Technology, v. 39, n. 551, p. 511-514, 1967.

HEITNER, C.; DIMMEL, D.; SCHMIDT, J. A. Lignin and lignans advances in chemistry. Boca Raton: Taylor \& Francis, 2010.629 p.

HILDEBRAND, J. Solubility. Journal of the American Chemical Society, v. 38, p. 1452-1473, 1916.

HOY, K. New values of solubility parameters from vapor pressure data. Journal of Paint Technology, v. 42, n. 541, p. 76-80, 1970. 
HU, T. Q. Characterization of lignocellulosic materials. Oxford: Blackwell, 2008. $370 \mathrm{p}$.

INSTITUTO NACIONAL DE GEOGRAFIA E ESTATÍSTICA (IBGE). Levantamento sistemático da produção agrícola, produção agrícola das safras de 2010. Rio de Janeiro, 2011. Disponível em: <

http://www.ibge.gov.br/home/estatistica/indicadores/agropecuaria/lspa/defaulttab.sht $\underline{m}$ >. Acesso em: 5 maio 2011.

IKUSHIMA, Y.; SAITO, N.; GOTO, T. Selective extraction of oleic, linoleic, and linolenic acid methyl esters from their mixture with supercritical carbon dioxideentrainer systems and a correlation of the extraction efficiency with a solubility parameter. Industrial \& Engineering Chemistry Research, v. 28, n. 9, p. 13641369, 1989.

IWAMOTO, E.; OHMORI, H.; YAMAMOTO, Y. Solute-solvent interactions in ion-pair extraction of tetraalkylammonium iodides. 3 . The role of relative permittivity and solubility parameter in nitrobenzene-tetrachloromethane mixtures at 25.degree.C. The Journal of Physical Chemistry, v. 87, n. 10, p. 1776-1782, 1983.

KAGLIWAL, L. D.; PATIL, S. C.; POL, A. S.; SINGHAL, R. S.; PATRAVALE, V. B. Separation of bioactives from seabuckthorn seeds by supercritical carbon dioxide extraction methodology through solubility parameter approach. Separation and Purification Technology, v. 80, n. 3, p. 533-540, 2011.

KIRK, R. E.; OTHMER, D. F. Kirk-Othmer encyclopedia of chemical technology. New York: Wiley, 2004. v. 22.

KLEMM, D.; HEUBLEIN, B.; FINK, H.; BOHN, A. Cellulose: Fascinating biopolymer and sustainable raw material. Angewandte Chemie-International Edition, v. 44, n. 22, p. 3358-3393, 2005.

LANG, Y. H.; CAO, Z. M.; JIANG, X. Prediction of solvents extraction - the organochlorine pesticides in soil using solubility parameter. Talanta, v. 66, n. 1, p. 249-252, 2005.

LIN, S. Y.; DENCE, C. W. Methods in lignin chemistry. Berlin: Springer-Verlag, 1992. $567 \mathrm{p}$. 
MAEKAWA, E.; ICHIZAWA, T.; KOSHIJIMA, T. An evaluation of the acid-soluble lignin determination in analyses of lignin by the sulfuric acid method. Journal of Wood Chemistry and Technology, v. 9, n. 4, p. 549-567, 1989.

MARABEZI, K. Estudo sistemático das reações envolvidas na determinação dos teores de lignina e holocelulose em amostras de bagaço e palha de canade-açúcar. 2009. 142 f. Dissertação (Mestrado em fisico-química) - Instituto de Química de São Carlos, Universidade de São Paulo, São Carlos, 2009.

MOHAMMAD, M. A.; ALHALAWEH, A.; VELAGA, S. P. Hansen solubility parameter as a tool to predict cocrystal formation. International Journal of Pharmaceutics, $v$. 407, n. 1-2, p. 63-71, 2011.

MUSSATTO, S.; DRAGONE, G.; GUIMARAES, P. M. R.; SILVA, J. P. A.; CARNEIRO, L. M.; ROBERTO, I. C.; VICENTE, A.; DOMINGUES, L.; TEIXEIRA, J. A. Technological trends, global market, and challenges of bio-ethanol production. Biotechnology Advances, v. 28, n. 6, p. 817-830, 2010.

NADA, A.; SEFAIN, M. Beatability and water-retention relations of heated wood and bagasse pulps. Cellulose Chemistry and Technology, v. 20, n. 4, p. 409-415, 1986.

NOVO, L. P.; GURGEL, L. V. A.; MARABEZI, K.; CURVELO, A. A. S. Delignification of sugarcane bagasse using glycerol-water mixtures to produce pulps for saccharification. Bioresource Technology, v. 102, n. 21, p. 10040-10046, 2011.

NOVO, L. P. Deslignificação glicerol/água de bagaço de cana-de-açúcar. 2009. 79 f. Monografia (Graduação) - Instituto de Química de São Carlos, Universidade de São Paulo, São Carlos, 2009.

PASQUINI, D. Polpação organosolve/dióxido de carbono supercrítico de bagaço de cana-de-açucar. 2004. 180 f. Tese (Doutorado) - Instituto de Química de São Carlos, Universidade de São Paulo, São Carlos, 2004.

PASQUINI, D.; PIMENTA, M. T. B.; FERREIRA, L. H.; CURVELO, A. A. S. Sugar cane bagasse pulping using supercritical $\mathrm{CO}_{2}$ associated with co-solvent 1butanol/water. Journal of Supercritical Fluids, v. 34, p. 125-131, 2005. 
PASQUINI, D.; PIMENTA, M. T. B.; FERREIRA, L. H.; CURVELO, A. A. S. Extraction of lignin from sugar cane bagasse and Pinus taeda wood chips using ethanol-water mixtures and carbon dioxide at high pressures. Journal of Supercritical Fluids, v. 36, n. 1, p. 31-39, 2005.

PEPPER, J. M.; BAYLIS, P. E. T.; ADLER, E. The isolation and properties of lignins obtained by the acidolysis of spruce and aspen woods in dioxane-water medium. Canadian Journal of Chemistry, v. 37, n. 8, p. 1241-1248, 1959.

PEREZ, D. S. Estudo cinético da deslignificação acetona-água do Eucalyptus urograndis. 1996. 114 f. Dissertação (Mestrado) - Instituto de Química de São Carlos, Universidade de São Paulo, São Carlos, 1996.

PEROBELLI, F. S.; ALMEIDA, E. S.; ALVIM, M. I. S. A.; FERREIRA, P. G. C. Produtividade do setor agrícola brasileiro (1991-2003): uma análise espacial. Nova Economia, v. 17, p. 65-91, 2007.

QUESADA-MEDINA, J.; LÓPEZ-CREMADES, F. J.; OLIVARES-CARRILLO, P. Organosolv extraction of lignin from hydrolyzed almond shells and application of the ठ-value theory. Bioresource Technology, v. 101, n. 21, p. 8252-8260, 2010.

SANADA, Y.; HONDA, H. Solvent extraction of coal - relation between the yield of extract and the solubility parameter of the solvent. Bulletin of the Chemical Society of Japan, v. 35, n. 8, p. 1358-1360, 1962.

SCHUERCH, C. The solvent properties of liquids and their relation to the solubility, swelling, isolation and fractionation of lignin. Journal of the American Chemical Society, v. 74, n. 20, p. 5061-5067, 1952.

SRINIVAS, K.; KING, J. W.; MONRAD, J. K.; HOWARD, L. R.; HANSEN, C. M. Optimization of subcritical fluid extraction of bioactive compounds using Hansen solubility parameters. Journal of Food Science, v. 74, n. 6, p. E342-E354, 2009.

SUN, F.; CHEN, H. Comparison of atmospheric aqueous glycerol and steam explosion pretreatments of wheat straw for enhanced enzymatic hydrolysis. Journal of Chemical Technology \& Biotechnology, v. 83, n. 5, p. 707-714, 2008.

TRIANA, O.; LEONARD, M.; SAAVEDRA, F.; FERNÁNDEZ, N.; GÁLVEZ, G.; PEÑA, $E$. Atlas del bagazo de la caña de azucar. México: GEPLACEA/PNUD/ICIDCA, 1990. 143 p. 
UTRACKI, L. A.; SIMHA, R. Statistical thermodynamics predictions of the solubility parameter. Polymer International, v. 53, n. 3, p. 279-286, 2004.

VERNERET, H. Solventes industriais propriedades e aplicações. São Paulo: Toledo, 1984. $145 \mathrm{p}$.

VIEIRA, L.; BREDARIOL, C. Política ambiental: histórico e crise. In: BREDARIOL, C. (Ed.). Cidadania e política ambiental. Rio de Janeiro: Record, 2006. cap. 3, p.77101.

VILLA, R. D.; DE OLIVEIRA, A. P.; NOGUEIRA, R. F. P. Avaliação dos parâmetros de solubilidade de Hildebrand/Hansen na seleção de solventes para a extração de pesticidas organoclorados do solo. Química Nova, v. 34, p. 1501-1506, 2011.

ZANIN, G. M.; SANTANA, C. C.; BON, E. P. S.; GIORDANO, R. C. L.; de MORAES, F. F.; ANDRIETTA, S. R.; NETO, C. C. D.; MACEDO, I. C.; FO, D. L.; RAMOS, L. P. FONTANA, J. D. Brazilian bioethanol program. Applied Biochemistry and Biotechnology, v. 84-6, p. 1147-1161, 2000.

ZHAO, Y.; ABRAHAM, M.; ZISSIMOS, A. Fast calculation of van der Waals volume as a sum of atomic and bond contributions and its application to drug compounds. Journal of Organic Chemistry, v. 68, n. 19, p. 7368-7373, 2003. 


\section{Anexo 1}

\section{HSP . m}

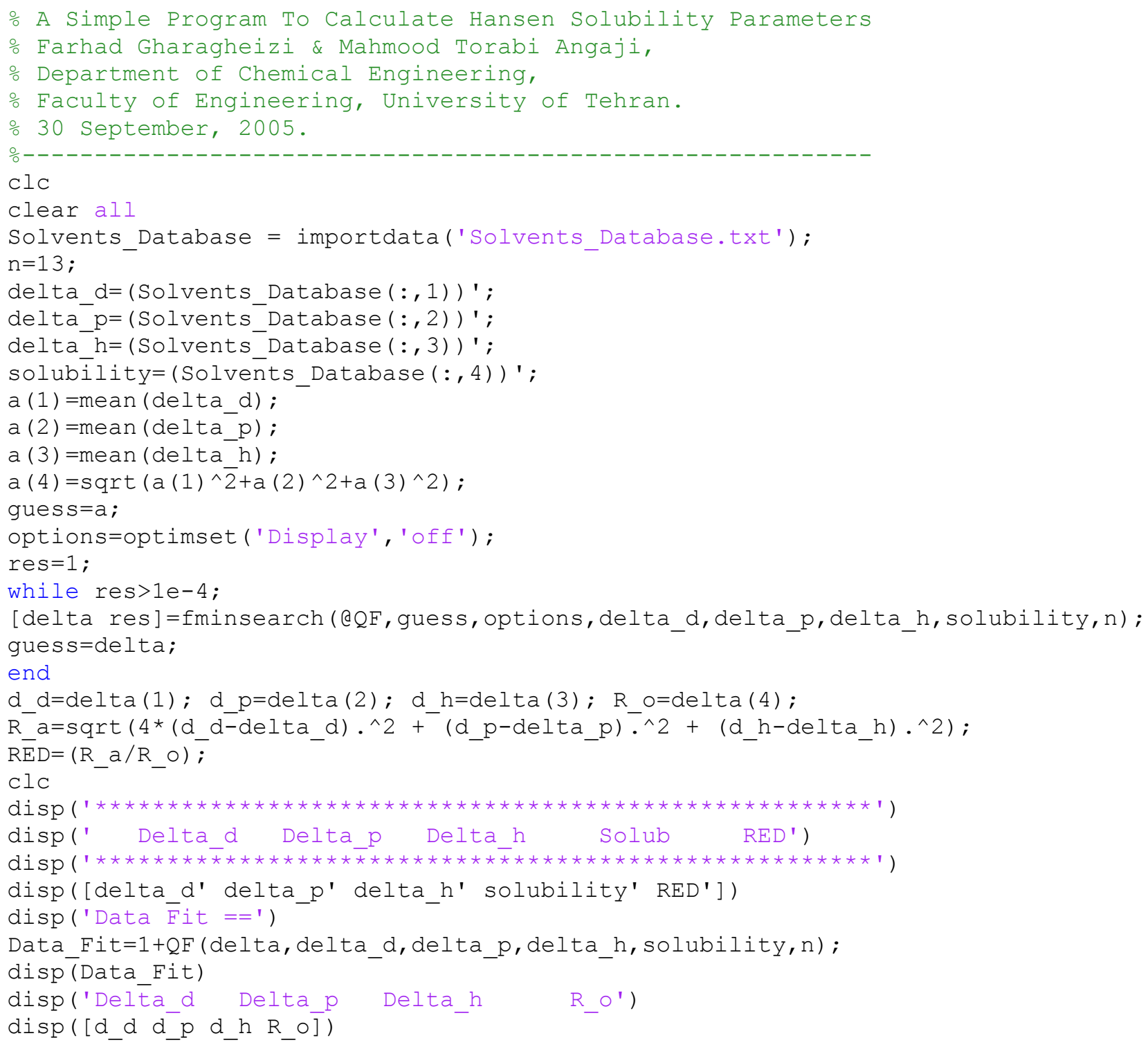

\section{QF.m}

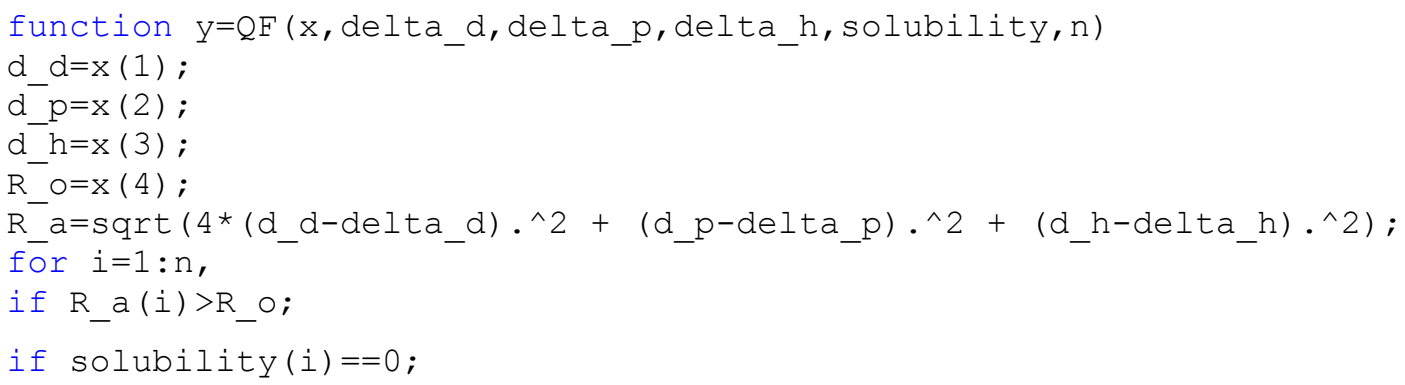


$A(i)=1$;

else

$A(i)=\exp \left(R \_o-R \_a(i)\right)$;

end

else R_a(i) $<$ R_o;

if solübility(i) $==0$;

$A(i)=\exp \left(R \_a(i)-R \_0\right)$;

else

$A(i)=1$;

end

end

end

$\mathrm{y}=\operatorname{abs}\left(\left((\operatorname{prod}(A))^{\wedge}(1 / \mathrm{n})\right)-1\right)$;

\section{Solvents Database.txt}

18.01 .42 .00

$\begin{array}{llll}16.8 & 0 & 0.2 & 0\end{array}$

15.959 .78 .820 ;

16.676 .7311 .430 ;

18.653 .2210 .891 .0 ;

15.1412 .6724 .31 .0 ;

15.779 .5221 .691 .0 ;

15.777 .0918 .991 .0 ;

15.956 .7318 .451 .0 ;

$15.8 \quad 5.7 \quad 14.50$;

15.516 .042 .30 ;

15.3217 .89 .720 ;

$15.50 \quad 10.96 \quad 10.530$ 


\section{Fluxograma do algoritmo do programa}

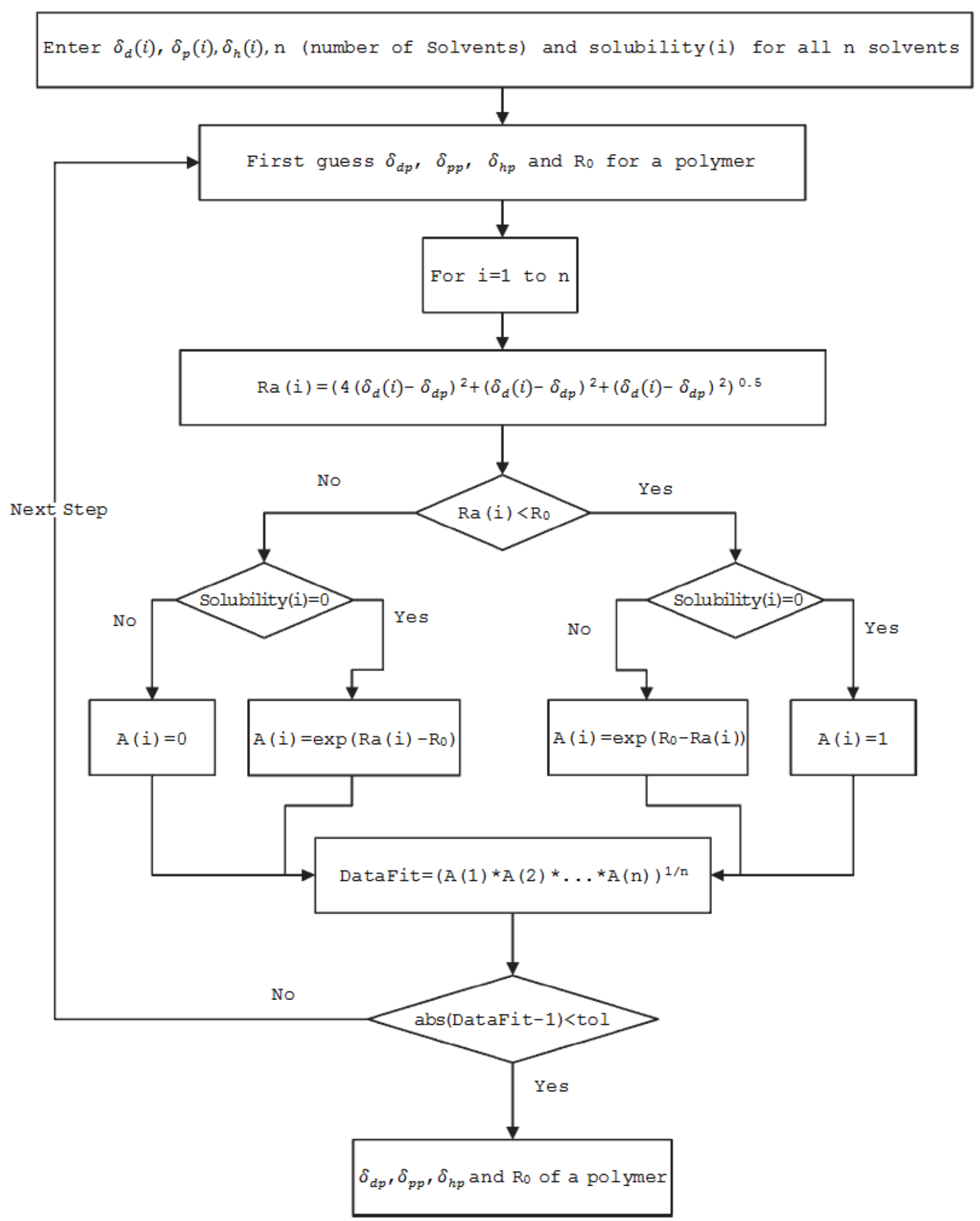

